\title{
Stand dynamics and disturbance history of five oak -dominated old -growth stands in the unglaciated Appalachian Plateau
}

James Spencer Rentch

West Virginia University

Follow this and additional works at: https://researchrepository.wvu.edu/etd

\section{Recommended Citation}

Rentch, James Spencer, "Stand dynamics and disturbance history of five oak -dominated old -growth stands in the unglaciated Appalachian Plateau" (2001). Graduate Theses, Dissertations, and Problem Reports. 1442.

https://researchrepository.wvu.edu/etd/1442

This Dissertation is protected by copyright and/or related rights. It has been brought to you by the The Research Repository @ WVU with permission from the rights-holder(s). You are free to use this Dissertation in any way that is permitted by the copyright and related rights legislation that applies to your use. For other uses you must obtain permission from the rights-holder(s) directly, unless additional rights are indicated by a Creative Commons license in the record and/ or on the work itself. This Dissertation has been accepted for inclusion in WVU Graduate Theses, Dissertations, and Problem Reports collection by an authorized administrator of The Research Repository @ WVU.

For more information, please contact researchrepository@mail.wvu.edu. 


\title{
Stand Dynamics and Disturbance History of Five Oak-dominated
}

\section{Old-growth Stands in the Unglaciated Appalachian Plateau}

\author{
James S. Rentch \\ Dissertation submitted to the Davis College of Agriculture, \\ Forestry, and Consumer Sciences \\ at West Virginia University in partial fulfillment \\ of the requirements for the degree of
}

Doctor of Philosophy

in

Forest Resource Science
Ray R. Hicks, Jr., Ph.D., Chair Dean W. Coble, Ph.D.
Jimmie J. Colbert, Ph.D.
Mary Ann Fajvan, Ph.D.
Steven L. Stephenson, Ph.D.
Division of Forestry
Morgantown, West Virginia 2001

Keywords: old-growth forest, oaks, Quercus, canopy disturbance, radial growth averaging, stand development

Copyright 2001 James S. Rentch 


\title{
ABSTRACT \\ Stand Dynamics and Disturbance History of Five Oak-dominated Old-growth Stands in the Unglaciated Appalachian Plateau
}

\begin{abstract}
James S. Rentch
Stand dynamics and canopy disturbance histories of five oak-dominated old-growth stands in eastern Ohio, southwestern Pennsylvania, and north central West Virginia were investigated using a combination of ecological field sampling techniques, dendrochronologogical methods, and a review of historical resources of original forest composition and patterns of human and natural disturbance. This study has three objectives: 1) determine the current composition, structure and successional status of these stands, 2) develop stand histories, identifying changes in composition and structure over time, and 3) relate these chronologies to the canopy disturbance regimes under which these forests have originated and persisted.

Witness tree tallies from $18^{\text {th }}$ century land surveys show that presettlement forests in the study areas were oak-dominated forests. Quercus alba was dominant by a large margin, at minimum twice as abundant as $Q$. velutina, the second ranked species. Acer saccharum and Fagus grandifolia were among the top ten ranked species at each site; however their importance value was consistently less than one-third the value for $Q$. alba. Quercus rubra, $Q$. prinus, Castanea dentata, and Acer rubrum were relatively minor components of presettlement forests, rarely ranked among the ten most abundant tree species.
\end{abstract}

At all five sites, the oldest trees were oaks and virtually no non-oak species were found in the older cohorts. At three sites, the oldest oaks date to well-defined time periods, suggesting that these stands initiated in the aftermath of major, stand-initiating disturbances. Following initiation, there was an extended pause in tree recruitment consistent with the stem exclusion and understory reinitiation stages of stand development. At the remaining two sites, the absence of clearly defined cohorts among the oldest trees, and continuous tree recruitment events preclude a reliable estimate of stand origin; however, these characteristics are consistent with the age structure of stands that have been uneven-aged for centuries.

On average, at least one canopy disturbance occurred on these study sites every three years; larger multiple-tree disturbances occurred every 17 years. Although there was some variation by site and by historical period, there has been little significant change in canopy disturbance rates for the 300-year period reviewed. A review of tree-ring chronologies yielded three growth strategies. For these oaks, the likelihood of originating in a large opening and achieving overstory status before canopy closure is about the same as the probability of requiring a major release, either from the understory or from a smaller gap that closed. Half of the cored trees established as seedlings or spouts individually, and $30 \%$ attained overstory status individually, members of no identifiable cohort. The majority of multiple-tree events occurred in gaps $<200 \mathrm{~m}^{2}$ in area. For trees that required a major canopy release, understory residence times averaged 89, 54, and 50 years for Quercus alba, Q. rubra, and Q. velutina, respectively. Although there is some historical precedence for these values, few contemporary second-growth forests contain understory oaks of this age, particularly $Q$. 
rubra. In view of the lack of change in canopy disturbance rates, these long understory residence averages suggest that the level of understory shade, and by implication, the abundance of shade tolerant understory species, was considerably less in the period before 1900. This hypothesis is consistent with presettlement survey tree-tallies, the absence of shade tolerant species in the oldest cohorts, fire frequency data from other studies, and the fact that virtually no oaks that recruited after 1900 did so after a prolonged period in the shaded understory. 


\section{TABLE OF CONTENTS}

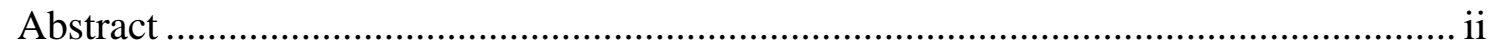

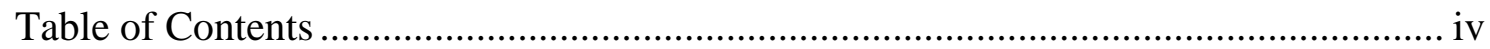

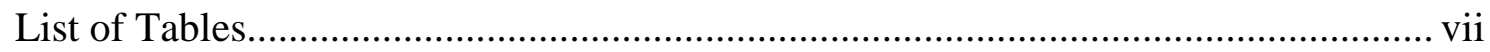

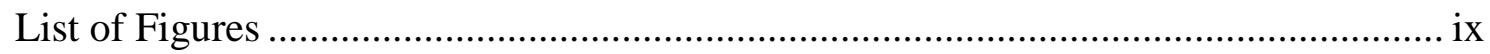

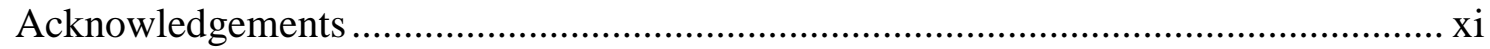

Chapter 1 INTRODUCTION

Introduction ....................................................................................... 1

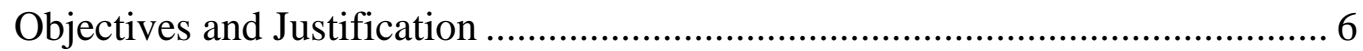

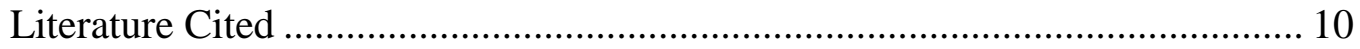

Chapter 2: PRESETTLEMENT Forest COMPOSITION

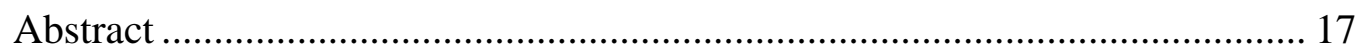

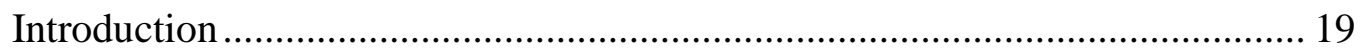

Methods

Presettlement Forest Composition ..................................................... 23

Sample Size Adequacy................................................................ 24

Contemporary Forest Composition ................................................. 25

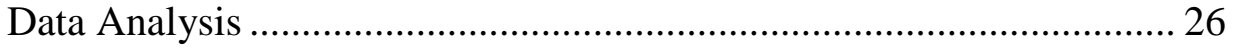

Results

Surveyor Bias in Presettlement Land Surveys ................................... 27

Presettlement Forest Composition and Structure.................................. 29

Comparison of Presettlement-era and Contemporary

Forest Composition .................................................................... 31

Discussion

Oak Domination of Presettlement Forests ........................................ 32

Forest Disturbance and Changes in Species Abundance ....................... 33

Successional Status of Presettlement and Contemporary Forests......... 37

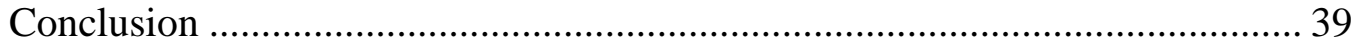

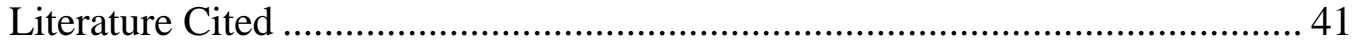

Chapter 3: Climate, CANOPy Disturbance, AND Radial Growth Averaging

IN A SECOND-GROWTH MiXed-OAK Stand IN THE WEST ViRginia UNIVERSITY FOREST

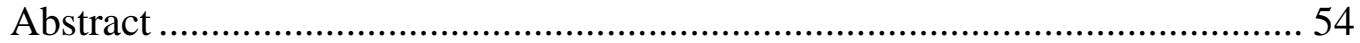

Introduction .......................................................................................... 56

Description of Study Area and Methods

Study Area and Pretreatment Stand Condition .....................................6 60

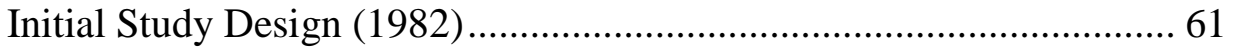

Increment Core Collection and Preparation ......................................... 62

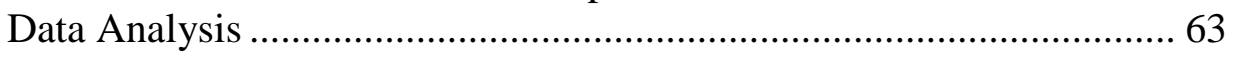

Results

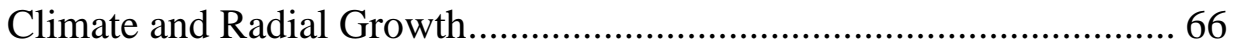

Canopy Disturbances and Radial Growth Averaging ........................ 67 
Discussion

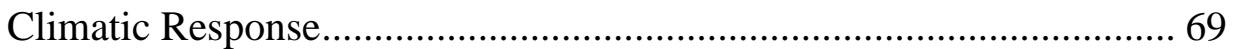

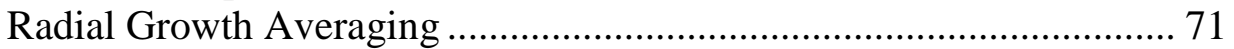

Limitations of Radial Growth Averaging .......................................... 74

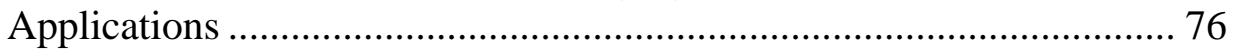

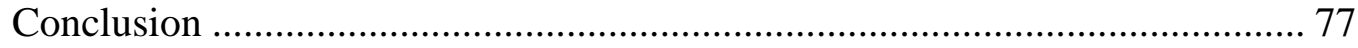

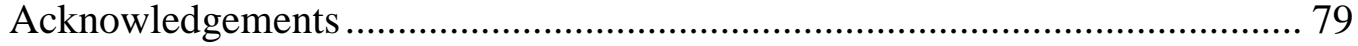

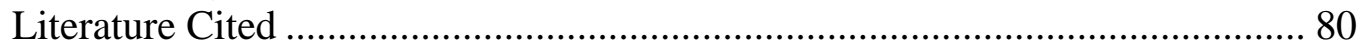

Chapter 4: $\quad$ Stand Composition, STRUCTURE, AND DyNAMics

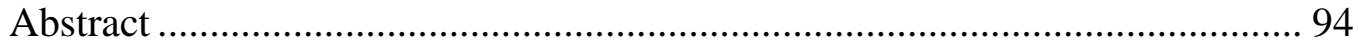

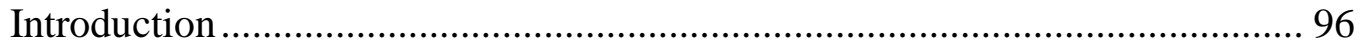

Study Area

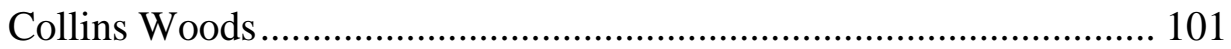

Wrights Woods .......................................................................... 102

Watter Smith State Park ................................................................. 103

Horners Woods.............................................................................. 103

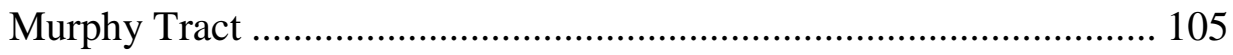

Climate, Soils, and Geologic Summary ......................................... 105

Field Methods

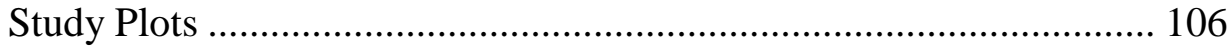

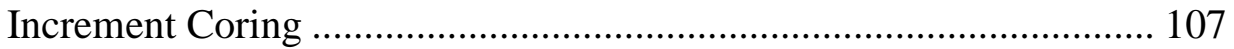

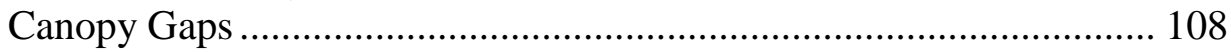

Laboratory and Analytic Methods

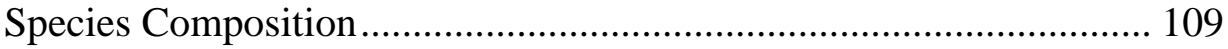

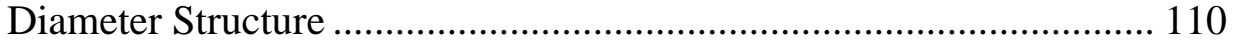

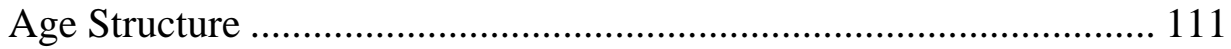

Coarse Woody Debris .................................................................... 112

Results

Canopy Gaps ....................................................................... 114

Species Composition ................................................................. 114

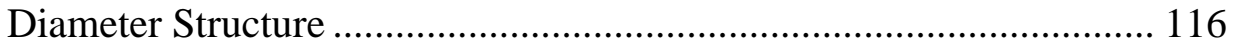

Age Structure ........................................................................... 119

Coarse Woody Debris ............................................................... 122

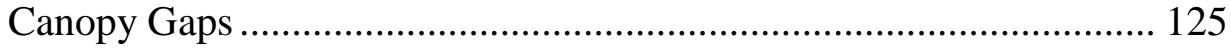

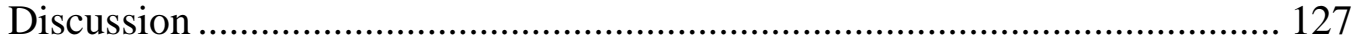

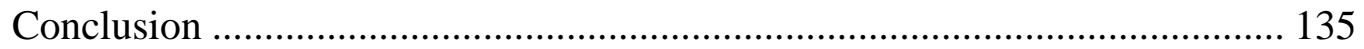

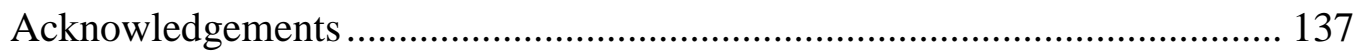

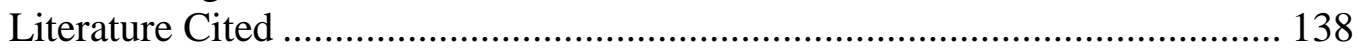

Chapter 5: CANOPY DisturbanCE INTERVALS, EARLY GROWTH RATES, AND CANOPY ACCESSION TRENDS

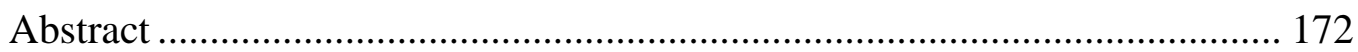

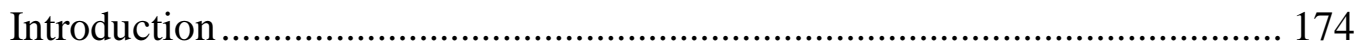

Study Area and Data Collection Methods.................................................. 177 
Data Analysis

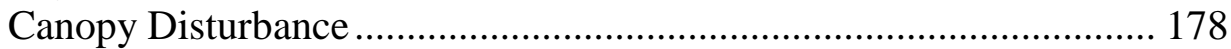

Canopy Disturbance Intervals ........................................................ 180

Early Growth Rates and Canopy Accession Trends .......................... 183

Spatial Distribution of Tree Establishment and Release Events ......... 185

Results

Stand Composition and Structure ..................................................... 186

Canopy Disturbances ............................................................... 187

Canopy Disturbance Intervals ...................................................... 188

Early Growth Rates and Canopy Accession Trends .......................... 190

Spatial Distribution of Tree Establishment and Release Events .......... 191

Discussion

Components of the Disturbance Regime ......................................... 192

Canopy Disturbance and Oak Recruitment...................................... 195

Understory Shade and Oak Recruitment........................................... 196

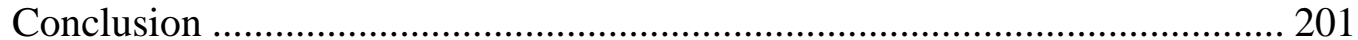

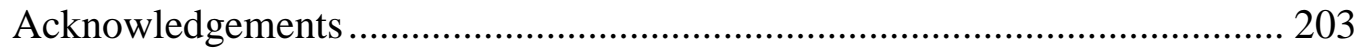

Literature Cited ................................................................................... 204 


\section{List of Tables}

Table 1.1 Percent total hardwood growing stock and percent average annual removals by volume for oak species-groups.

Table 2.1 More common components of species-groups used in FIA surveys .......... 47

Table 2.2 Abundance of tree species cited as witness trees in early land surveys and deeds for five counties in Ohio, Pennsylvania, and West Virginia

Table 2.3 Comparison of species-group importance value (IV) and change in rank (dRk) for presettlement and USDA Forest Service FIA data....

Table 3.1 Proportion of standardized tree-ring variation $\left(\mathrm{R}^{2}\right.$ climate $)$ that can be attributed to influence of 32 climate variables (monthly precipitation and average monthly temperature, June-December of previous year, and January-September of current year), by species and crown release level.

Table 3.2 Results of analysis of variance of \% growth change (\%GC, dependent variable) as a function of $\%$ crown release (\%CR), lag, and time interval (independent variables) using the General Linear Model Procedure

Table 3.3. Coefficients of the linear model: percent growth change $(\% \mathrm{GC})=$ $\mathrm{a}+\mathrm{b}^{*}$ percent crown release (\%CR) for lags of 1-3 years and averaging intervals of 7-12 years for northern red oak and chestnut oak

Table 4.1 Percent of $4500 \mathrm{~m}^{2}$ plot area represented by crown area of cored canopy trees, and percent canopy basal area represented by cored canopy trees

Table 4.2 Summary statistics from COFECHA evaluation of cross-dating of individual oak increment cores.

Table 4.3 Summary site statistics for five oak oak-dominated old-growth sites in Ohio, Pennsylvania, and West Virginia

Table 4.4 Importance values, basal area, and abundance for overstory trees species $(\mathrm{dbh} \geq 15 \mathrm{~cm})$ at five old-growth sites in Ohio, Pennsylvania, and West Virginia.

Table 4.5 Importance values and abundance for understory tree species $(15 \mathrm{~cm}>\mathrm{dbh} \geq 2.5 \mathrm{~cm})$ at five old-growth sites in Ohio, Pennsylvania, and West Virginia.

Table 4.6 Seeding density of woody species from nine oak-dominated old-growth stands in Ohio, Pennsylvania, and West Virginia

Table 4.7 Q-factors calculated from the ratio of numbers of stems present in two consecutive size-classes, for nine old-growth study plots

Table 4.8 Volume and basal area of coarse woody debris $(\mathrm{min}$. dia. $=15 \mathrm{~cm}$ ) at five oak-dominated old-growth sites in Ohio, Pennsylvania, and West Virginia, by type and species

Table 4.9 Ratio of dead to live stems by $10 \mathrm{~cm}$ diameter classes 
Table 4.10 Canopy gap summary statistics for nine 0.45 ha study plots in five oak-dominated old-growth forests in Ohio, Pennsylvania, and West Virginia

Table 5.1 Disturbance intervals for 1700-1990, for five oak- dominated old-growth sites in Ohio, Pennsylvania, and West Virginia, and three additional sites in Ohio, Kentucky, and North Carolina

Table 5.2 Disturbance intervals for three historical periods for five oldGrowth sites in Ohio, Pennsylvania, and West Virginia, and three additional sites in Ohio, Kentucky, and North Carolina

Table 5.3 Summary of growth trends and origin of canopy oak trees based on early growth rates and identification of major release events (\%GC $\geq 100 \%)$ using radial growth averaging...

Table 5.4 Mean understory residence time and dbh (inside bark) at canopy accession for four oak species.....

Table 5.5 Frequency of patch-size and number of trees involved/patch for synchronous establishment and major release events. 214 


\section{List of Figures}

Figure 1.1 Location map of five oak-dominated old-growth study sites

Figure 2.1 Location map of five oak-dominated, old-growth study sites and USDA Forest Service FIA county inventories

Figure 2.2 Diameter distribution of witness trees from township surveys, Kirkwood Township, Belmont County, Ohio, 1786-1804.

Figure 2.3 Cluster analysis of presettlement-era forest composition based on witness tree tallies and modern USDA Forest Service Forest Inventory Analysis (FIA) data.

Figure 2.4 Comparison of a) importance values and b) diameter distribution (Belmont County, Ohio, only) using witness tree tallies and FIA data

Figure 3.1 Response function of northern red oak ............................................... 90

Figure 3.2 Response function of chestnut oak ...................................................... 91

Figure 3.3 Average ring-width (a) and percent growth change (b) for five levels of crown release for northern red oak, 1970-1990.

Figure 3.4 Average ring-width (a) and percent growth change (b) for five levels of crown release for chestnut oak, 1970-1990.

Figure 4.1 Location map of five oak-dominated old-growth study sites 156

Figure 4.2 Cluster analysis of nine oak-dominated old-growth study plots using species importance value.

Figure 4.3 Detrended correspondence analysis of overstory $(\mathrm{dbh} \geq 15 \mathrm{~cm})$ and understory $(2.5 \mathrm{~cm} \leq \mathrm{dbh}<15 \mathrm{~cm})$ composition for nine study plots, by species importance value.

Figure 4.4 Diameter distributions of nine old-growth study plots in Ohio, Pennsylvania, and West Virginia

Figure 4.5 Examples of diameter distributions trends for selected species

Figure 4.6 Density distribution of all stems $(\mathrm{dbh}>2.5 \mathrm{~cm})$ for five old-growth stands in Ohio, Pennsylvania, and West Virginia

Figure 4.7 Diameter $(\mathrm{cm})$ versus age (at $\mathrm{dbh}$ ) scattergrams for cored overstory trees at five sites.

Figure 4.8 Examples of white oaks in initial disturbance-related cohort that have early growth rates that suggest establishment in large gap or open-grown conditions

Figure 4.9 Diameter distribution of coarse woody debris (> $15 \mathrm{~cm}$ at base) by percent of total for $10 \mathrm{~cm}$ diameter classes....

Figure 4.10 Morisita index of dispersion $\left(\mathrm{I}_{\mathrm{d}}\right)$ for volume of downed logs and frequency of standing snags at $15 \mathrm{~m}, 30 \mathrm{~m}, 45 \mathrm{~m}$, and $60 \mathrm{~m}$ spatial scales

Figure 4.11 Density distribution of subplot aspect and direction of fall for snaps and tips for five oak-dominated old-growth forests in Ohio, Pennsylvania, and West Virginia

Figure 4.12 Diameter distribution of gap makers (a), gap fillers (b), and border trees (c) by percent of total 170 
Figure 4.13 Detrended correspondence analysis of understory (_us), understory regeneration (_reg) and and gap regeneration (_gap) plots, by species importance values

Figure 5.1 Location map of five oak-dominated, old-growth study sites and three additional oak sites with tree-ring data obtained from International Tree-ring Data Bank

Figure 5.2 Examples of suggested classification of tree-origin based on early growth rates and presence/absence of a major crown release $(\% \mathrm{GC} \geq 100 \%)$

Figure 5.3 Examples of red oaks and black oaks that initiated in understory and survived for an extended period until overhead release and canopy accession

Figure 5.4 Plot maps of dbh-age and release dates, and cohorts of cored trees

Figure 5.5 Probability of a thunderstorm with winds in excess of $57 \mathrm{mph}$ hitting any point in five general areas, based on 1980-1994 data.

Figure 5.6 Chronology of oak tree-origin and canopy accession dates for five oak-dominated old-growth study sites 227 


\section{Acknowledgements}

Many individuals and organizations deserve my sincere thanks for their assistance and guidance during this study. Dr. Ray R. Hicks, Jr. gave me the opportunity to be a full time graduate student, and provided the impetus for examining old-growth oak forests. As a forest ecologist, teacher, advisor, musician, and contemporary, Dr. Hicks is without parallel. From him, I learned that the big picture is paramount; details and statistics should illuminate, not obfuscate essential relationships. To Dr. Ronald Fortney I also owe a considerable debt. His unbridled enthusiasm for field ecology proved to be a contagion, and converted what was initially a casual interest on my part into a hobby, and now a vocation. Dr. Mary Ann Fajvan taught me the value of using silvicultural management methods to better understand natural stand processes, a relationship that is at the heart of this dissertation. Dr. Jimmie Colbert introduced me to the science of dendrochronology, and its utility in documenting stand history and dynamics. Dr. Dean Coble removed much of the inherent mystery of statistical analysis. After working with Dr. Steve Stephenson for over a decade, I have benefited greatly from his expertise in field biology and grasp of fundamental ecological relationships. Finally, my children Sarah Turner and Casey Rentch, and my father, J. Kenneth Rentch, have been supportive and generous beyond my expectations. 


\section{CHAPTER 1}

\section{INTRODUCTION}

This study examines the stand dynamics and disturbance histories of five oak (Quercus L.) dominated old-growth stands in eastern Ohio, southwestern Pennsylvania, and central West Virginia (Figure 1.1). The oldest trees span a 380-year historical continuum that begins near the end of Native American occupation of the region, includes the arrival and settlement of EuroAmericans during the late 1700s and early 1800s, and concludes during the modern era. The value of these stands derives primarily from their age and the fact that they have never been extensively logged and are several hundred years removed from a major, stand-initiating disturbance. At the same time, they have been influenced by human disturbance. During the 300-year period reviewed, fire frequency has declined significantly in the region (Abrams 1992;

Lorimer 1993; Wade et al. 2000). In some areas, deer densities are 3-6 times presettlement values (Alverson et al. 1994; Diefenback et al. 1997). The study areas include, or soon will include, the ranges of exotic diseases and pests such as chestnut blight, Dutch elm disease, beech bark disease (Hicks and Mudrick 1993), and gypsy moth (Liebhold et al. 1997). Very high levels of acidic deposition occur in the study area (Adams 1999; Driscoll et al. 2001; Rentch and Hicks in press), affecting surface water chemistry, soil nutrient status, and basic physiological process of tree growth (Demchik and Sharpe 2000).

The stands included in this study are "stable" in the sense that they have maintained a significant oak component for the time period reviewed, and thus are representative of presettlement-era forests. They are also dynamic. Downed logs, snags, and canopy gaps are 
evidence of recent tree death and canopy disturbance. Single-tree and multiple-tree establishment events from the tree-ring record point to past disturbance, changes in composition and structure, and, over time, the process of stand development. Tree-ring chronologies also provide a record of environmental conditions during both individual tree and stand establishment, and are a valuable data source for reconstructing rates of canopy disturbance, tree growth, and canopy accession over several centuries.

Oaks are more closely identified with the central hardwood forest region than any other genus (Hicks 1998). White oak (Quercus alba L.), northern red oak (Q. rubra L.), and black oak (Q. velutina Lam.), are the most widely distributed (Burns and Honkala 1990), and along with chestnut oak (Q. prinus L.), are the principal oak species in this study. As many as eight other oak species have local significance in different areas of the central hardwood forest and on specific sites. On average, oaks constitute $37 \%$ of the growing stock by volume, and $47 \%$ of the average annual removals for the states of West Virginia, Pennsylvania, Virginia, Ohio, and Kentucky (Table 1.1, USDA 2001). Oak acorns are a valuable source of hard mast for wildlife, particularly during winter, and may represent $76 \%$ by volume of deer's diet during bumper seed years (Harlow et al. 1975). Wolff (1996) suggests that acorns function as a 'keystone' forest resource by influencing small mammal prey populations. More than 180 species of birds and mammals use acorns as food, including squirrels, black bears, blue jays, white-tailed deer, turkey, quail, mice, voles, chipmunks, ducks, and raccoons (Burns and Honkala 1990; Greenberg 2000).

There is compelling evidence that oaks have dominated eastern deciduous forests for thousands of years. During a brief interstadial period of slightly warmer climate approximately 50,000 years ago, spruce (Picea spp.) and pine (Pinus spp.) dominated the vegetation in the 
central Midwest, however 10-20\% of the pollen evidence came from oaks (Heusser and King 1988). The modern distribution and composition of North American forests was initiated after sudden warming and melting of the Wisconsin ice sheets 16,000 years ago. This event created conditions for the northward migration of the individual components of the plant assemblage that comprise the Mixed Mesophytic forest from their refugia in the lower Mississippi Valley and southern Coastal Plain. Climate change was the ultimate cause of tree migration, but climate changed more rapidly than species could respond. Species migrated at different rates, using different routes, independent of each other (Watts 1979; Davis 1981).

As the climate warmed, oak spread rapidly, reaching the Midwest about 10,000 years ago, and its present range about 7000 years ago (Davis 1981). The migration route of beech (Fagus sp.) was east of the Appalachian Mountains, and thus oak populations preceded beech in the Midwest by 2000 to 4000 years (Webb 1988). Chestnut (Castanea spp.) was the slowest genus to expand northward, reaching New England as late as 2000 years ago (Watts 1979). Thus while climate change initiated species migrations, the rate of spread was influenced by the migration route and temporary physical barriers, the availability of propagules, and the ability of seedlings to survive in competition with plants already growing on a site (Davis 1981). What are considered stable plant assemblages have been, in fact, highly variable over time, seldom maintaining a constant species composition for more than 2000 years at a time (Davis 1981; Sprugel 1991).

More recent pollen records suggest that oaks were dominant in eastern deciduous forests when first settled by Euro-Americans (Russell 1980; Larabee 1986; Delcourt and Delcourt 1998). Delcourt and Delcourt (1987) found that by presettlement times oak constituted more than $60 \%$ of the forest composition within the central Appalachian Mountains. These findings 
are consistent with reconstructions of original forest composition from early land surveys. Witness tree tallies from Ohio (Sears 1925), southwestern Pennsylvania (Abrams and Downs 1990), and eastern West Virginia (Abrams and McCay 1996), as well as New Jersey and New York (Russell 1980; Loeb 1987) attest to the importance of oak in eastern presettlement forests. Dominance of eastern upland forests in the oak-chestnut region by species more shade tolerant than oak was uncommon outside the more mesic and protected environments (Abrams and Downs 1990; Nowacki and Abrams 1992), and there is little indication in the early literature of conversion of oak forests to other species, even when logged by early settlers (Greeley and Ashe 1907; Lorimer et al. 1994).

The long-term dominance of oaks in eastern forests is somewhat surprising, since the oak species of this study are generally classified as mid-successional species (Burns and Honkala 1990). Trimble (1975) classified white oak, chesnut oak, black oak, and northern red oak as intermediate in shade tolerance, however, within this designation, there is considerable variability. White oak is the most tolerant of the four, capable of surviving in the understory for up to 90 years (Rogers 1990). Oaks are generally most tolerant as seedlings (Burns and Honkala 1990), however dense understory shade imposes a physiological limitation on juvenile growth that often results in poor seedling survival on better quality sites (Phares 1971; Lorimer et al. 1994). They all respond well to partial release (McQuilkin 1990; Rogers 1990; Sander 1990a, 1990b). Of these four species, northern red oak and black oak are faster growers, capable of several flushes of growth when environmental conditions permit (Crow 1988; Sander 1990b; Dickson 1994). Peet and Loucks (1977) considered red oak a pioneer species on mesic sites because it appeared unable to survive under its own canopy. 
Oaks also show traits that are characteristic of late seral species. They employ stress tolerant (Grime 1977) or conservative (Bormann and Likens 1979) growth strategies (e.g., delayed sexual maturity, heavy seed, high root to shoot ratios, and great longevity). They are well adapted to drought (Abrams 1990), and some types of ground level disturbances such as fire and herbivory. They have thick bark (Abrams 1990), resprout readily from smaller stems and roots (Burns and Honkala 1990), and are able to resist rot after scarring because they readily compartmentalize wounded tissue (Smith and Sutherland 1999).

In the last 50 years the declining dominance of oaks has become acute on better quality sites. Oak regeneration is often poor whether they are managed in an even-aged condition (Weitzman and Trimble 1957; Carvell and Tryon 1961; Beck and Hooper 1986), or in an unmanaged old-growth condition (McGee 1984; Parker et al. 1985; Abrams and Downs 1990). This trend is not limited to the eastern United States. Oak regeneration failures have occurred in California (Muick 1991), Britain (Savill 1991), and Japan (Abrams et al. 1999). A list of the "usual suspects" can be quite lengthy (Lorimer 1993). Erratic seed production (Smith 1993), acorn herbivory (Marquis et al. 1976; Galford et al. 1991), deer browse (Maquis et al. 1976), decreased fire frequency (Abrams 1992; Lorimer 1993), shade from tall understory vegetation (Lorimer et al. 1994), and climate change (McCarthy et al. 2001) have all been implicated.

Because of their antiquity, the old-growth stands of this study present a valuable source of long-term data on individual tree and stand dynamics of oak forests in this region. In this study, I use the term "old-growth" as a stage of stand development, as defined by Oliver and Larsen (1996). Their forest model traces the developmental sequence following a major disturbance through four stages: stand initiation, stem exclusion, understory reinitiation, and oldgrowth. Transitional old-growth stands contain a few remnants of the initial cohort that were 
established after the last major, stand-wide disturbance. True old-growth occurs when all of the members of the initial disturbance-related cohort have died, and have been replaced by younger trees in a wide range of age-classes.

Oliver and Larsen's (1996) definition is based on a unique stand structure associated with a functional stage of stand development. The key requirement is elapsed time between major disturbance events; major disturbances must be far enough apart so that the initial cohort can approach its maximum longevity and the full developmental sequence can occur. In contrast, other definitions rely on a class of structural attributes such as large tree size at great spacing, dominant trees near their maximum life expectancy, high species richness, a high degree of vertical stratification, uneven age distribution, and threshold values for basal area, stem density, and coarse woody debris (Martin 1992; McCarthy 1995; Tyrrell et al. 1998). These characteristics may be associated with old-growth, but they may also occur in stands in earlier stages of development. For example, large, old trees often occur in two-aged stands as residuals from earlier logging. Stratification of the canopy into several layers is found in even-aged stands of species with differing tolerances of shade, as well as old-growth (Oliver and Larsen 1996). The presence of coarse woody debris may be as closely related to decomposition rates and climate as a particular stage of stand development. Hunter and White (1997) compared characteristics attributed to old-growth and younger stands (e.g., net primary production, biomass, gap size, species richness and composition) and found no clearly defined ecological thresholds that separate the two.

\section{Objectives and Justification}

This study has three primary objectives: 1 ) determine the current composition, structure, and successional status of five oak-dominated, old-growth stands, 2) develop stand histories, 
identifying changes in composition and structure over time, and 3) relate these chronologies to the disturbance regimes under which these forests have developed and persisted. The study methodology includes standard ecological field sampling techniques, dendroecological methods, and a review of historical resources related to original forest composition and patterns of human and natural disturbance.

Chapter 2 of this study employs witness tree tallies from early land surveys, historical accounts of land use, forest composition, and forest clearing, and contemporary forest inventories from USDA Forest Service Forest Inventory and Analysis (FIA) database to address three related questions. First, what was the dominant presettlement forest composition and structure? For those counties in which the old-growth study sites occur, what are the principal differences between presettlement and contemporary forests? Do forest structures suggest the main components of the disturbance regime?

Chapter 3 addresses methodological issues that are common in forest reconstructive studies. The quality of the written, historical record is often poor, or non-existent. Second, the dendrochronological methodology used should a) distinguish between the effects of climate and those caused by disturbance, and b) provide a means of quantifying increases in radial growth as a function of disturbance intensity. In this chapter, I test a method proposed by Nowacki and Abrams (1997) that uses radial growth averaging to reconstruct disturbance history. Using data from a 1982 thinning experiment (Lamson et al. 1990), I first compare the relative contributions of climatic and non-climatic variation to radial growth in a second-growth mixed-oak forest. I then use radial growth averaging to derive a relationship between the number of sides released (i.e., disturbance intensity and crown release) and radial growth increases of overstory, codominant red oak and chestnut oak. 
In Chapter 4, species importance values by strata, size- and age-distributions, the distribution of coarse woody debris, and existing canopy gaps are used to analyze current composition and structure of the five stands (Objectives 1 and 2). Using this, I propose a chronology of tree establishment events and trace the process of stand development. Finally, Chapter 5 addresses the hypothesis that changes in composition can be traced to changes in the disturbance regime (Objective 3). Here, I apply the radial growth averaging technique tested in Chapter 3 to the old-growth stands in order to estimate the frequency of canopy disturbances over time. Plot maps and establishment and tree release chronologies are used to estimate the size distribution of openings created by disturbances. Finally, early growth rates and the presence or absence of a major crown release are used to determine oak modes of establishment and canopy recruitment, and by inference, the understory light environment in which these trees originated.

This study can be justified for the following reasons: First, the composition of many oakdominated old-growth and second growth forests is shifting toward increasing importance of mesophytic and shade tolerant species. Despite the prevalence of oak forests in the region, relatively few studies have been done in oak-dominated forests looking specifically at disturbance regimes over a long period of time (Runkle 1990). Second, these stands provide a direct link to the original vegetation of the pre-settlement period, and a record of the progressive modification of that vegetation by human and natural causes. An account of these changes is an important biological, as well as social resource. Finally, these stands provide a link to the future. An examination of patterns of structural change may serve as a guide to the future of old-growth forests, as well as second-growth forests if left undisturbed. 
One challenge of contemporary oak silviculture is to understand the conditions under which these stands first originated and flourished, and in so doing, design techniques that are consistent with those natural conditions and processes. Naturalness as a desired condition represents the best chance of achieving Leopold's most famous objective: "to keep every cog and wheel" (Aplet et al. 1993). No single ecosystem condition can be identified as the natural condition (Davis 1981; Sprugel 1991). Nor is it possible to fully recreate the conditions under which the stands of this study, or comparable oak forests of the past, arose. It is possible, and a desirable objective, to define naturalness by the historical range of variability of forest characteristics over time (Aplet 2000), and to use this as a blueprint for silvicultural prescriptions and management strategies that sustain pattern and process across the landscape (SAF 1993). 


\section{Literature cited}

Abrams, M. D. 1990. Adaptations and responses to drought in Quercus species of North America. Tree Physiology 7: 227-238.

Abrams. M. D. 1992. Fire and the development of oak forests. BioScience 42: 346-353

Abrams, M. D. and J. A. Downs. 1990. Successional replacement of old-growth white oak by mixed mesophytic hardwoods in southwestern Pennsylvania. Can. J. For. Res. 20: 1864-1870.

Abrams, M. D. and D. M. McCay. 1996. Vegetation-site relationships of witness trees (17801856) in the presettlement forests of eastern West Virginia. Can. J. For. Res. 26: 217-224.

Abrams, M. D., C. A. Copenheaver, K. Terazawa, K. Umeki, M. Takiya, and N. Akashi. 1999. A 370-year dendroecological history of an old-growth Abies-Acer-Quercus forest in Hokkaido, northern Japan. Can. J. For. Res. 29: 1891-1899.

Adams, M. B. 1999. Acidic deposition and sustainable forest management in the central Appalachians, USA. For. Ecol. Manage. 122:17-28.

Aplet, G. 2000. A new definition of silviculture: prescriptions from the historical range of variability. Yale Forest Forum Review 3: 11-13.

Aplet, G. H., N. Johnson, V. A. Sample, and J. T. Olson (eds.). 1993. Defining sustainable forestry. Island Press, Covelo, CA.

Beck, D. E. and R. M. Hooper. 1986. Development of a southern Appalachian hardwood stand after clearcutting. South. J. Appl. For. 10: 168-172.

Bormann, F. H. and G. E. Likens. 1979. Pattern and process in a forested ecosystem. SpringerVerlag, New York, NY

Burns, R. M. and B. H. Honkala (tech. coords.) 1990. Silvics of North America. Vol 2. Hardwoods. Agriculture Handbook 654. USDA Forest Service, Washington, DC.

Canham, C. D. 1990. Suppression and release during canopy recruitment in Fagus grandifolia. Bull. Torrey Bot. Club. 117: 1-7.

Carvell, K. L. and E. H. Tryon. 1961. The effect of environmental factors on the abundance of oak regeneration beneath mature oak stands. For. Sci. 7: 98-105.

Crow, T. R. 1988. Reproductive mode and mechanisms for self-replacement of northern red oak (Quercus rubra): a review. For. Sci. 34: 19-40. 
Davis, M. B. 1981. Quaternary history and the stability of forest communities. Pp. 132-153 In West, D. C., D. B. Botkin, and H. H. Shugart, eds. Forest succession. Springer-Verlag, New York, NY.

Delcourt, P. A. and H. R. Delcourt. 1987. Long-term forest dynamics of the temperate zone. Springer-Verlag, New York, NY.

Delcourt, H. R. and P. A. Delcourt. 1998. Pre-Columbian native American use of fire on southern Appalachian landscapes. Conservation Biology 11: 1010-1014.

Demchik, M. C. and W. E. Sharpe. 2000. The effect of soil nutrition, soil acidity and drought on northern red oak (Quercus rubra L.) growth and nutrition on Pennsylvania sites with high and low red oak mortality. For. Ecol. Manage. 136: 199-207.

Dickson. R. E. 1994. Height growth and episodic flushing in northern red oak. Pp. 1-9 In Isebrands, J. G., and R. E. Dickson, comps. Biology and silviculture of Northern red oak in the north central region: a synopsis. USDA For. Ser. Gen Tech. Rep. NC-173.

Diefenback, D. R., W. L. Palmer, and W. K. Shope. 1997. Attitudes of Pennsylvania sportsmen towards managing white-tailed deer to protect the ecological integrity of forests. Wildlife Society Bulletin 25: 244-251.

Driscoll, C. T., G. B. Lawrence, A. J. Bulger, T. J. Butler, C. S. Cronan, C. Eagar, K. F. Lambert, G. E. Likens, J. L. Stoddard, and K. C. Weathers. 2001. Acidic deposition in the northeastern United States: sources and inputs, ecosystem effects, and management strategies. BioScience 51: 180-198.

Galford, J., L. R. Auchmoody, H. C. Smith, and R. S. Walters. 1991. Insects affecting establishment of northern red oak seedlings in Pennsylvania. In McCormick, L. H. and K. W. Gottschalk, eds. Proceedings of the $8^{\text {th }}$ annual Central Hardwood Forest Conference. USDA For. Ser. Gen. Tech. Rep. NE-148.

Greeley, W. B. and W. W. Ashe. 1907. White oak in the southern Appalachians. USDA For. Ser. Circular 105.

Greenberg, C. H. 2000. Individual variation in acorn production by five species of Appalachian oaks. For. Ecol. Manage. 132: 199-210.

Grime, J. P. 1977. Evidence for the existence of three primary strategies in plants and its relevance to ecological and evolutionary theory. Am. Nat. 111: 1169-1194.

Harlow, R. F., J. B. Whelan, H. S. Crawford, and J. E. Skeen. 1975. Deer foods during years of oak mast abundance and scarcity. Journal of Wildlife Management 39: 330-336.

Heusser, L. E. and J. E. King. 1988. North America. Pp. 193-236 In Huntley, B and T. Webb, III, eds. Vegetation history. Kluwer Academic Publishers, Boston, MA. 
Hicks, R. R., Jr. 1998. Ecology and management of central hardwood forests. John Wiley \& Sons, New York, NY.

Hicks, R. R., Jr., and D. A. Mudrick. 1994. Forest health 1993: a status report for West Virginia. West Virginia Department of Agriculture, Charleston, WV.

Hunter, M. L., Jr. and A. S. White. 1997. Ecological thresholds and the definition of old-growth forest stands. Natural Areas Journal 17: 292-296.

Lamson, N. I., Smith, H. C., Perkey, A. W., and Brock, S. M. 1990. Crown releases increase growth of crop trees. USDA For. Ser. Research Paper NE-635.

Larabee, P. A. 1986. Late-quaternary vegetational and geomorphic history of the Allegheny Plateau at Big Run Bog, Tucker County, West Virginia. M.S. Thesis, University of Tennessee, Knoxville, TN.

Liebhold, A. M., K. W. Gottschalk, E. R. Luzader, D. A. Mason, R. Bush, and D. B. Twardus. 1997. Gypsy moth in the United States: an atlas. USDA For. Ser. Gen. Tech. Rep. NE-223.

Loeb, R. E. 1987. Pre-European settlement forest composition in east New Jersey and southeastern New York. Am. Mid. Nat. 118:414-423.

Lorimer, C. G. 1993. Causes of the oak regeneration problem. Pp. 14-39 In Loftis, D. L. and C. E. McGee, eds. Oak regeneration: serious problems, practical recommendations. USDA For. Ser. Res. Pap. NE-356.

Lorimer, C. G., J. W. Chapman, and W. D. Lambert. 1994. Tall understory vegetation as a factor in the poor development of oak seedlings beneath mature stands. J. Ecology 82: 227-237.

Martin, W. H. 1992. Characteristics of old-growth mixed mesophytic forests. Natural Areas Journal 12: 127-135.

McCarthy, B. C. 1995. Eastern old-growth forests. Ohio Woodland Journal 2: 8-10.

McCarthy, B. C., C. J. Small, and D. L. Rubino. 2001. Composition, structure and dynamics of Dysart Woods, an old-growth mixed mesophytic forest of southeastern Ohio. For. Ecol.

Manage. 140: 193-213.

McGee, C. E. 1984. Loss of Quercus spp. dominance in an undisturbed old-growth forest. Journal of the Elisha Mitchell Scientific Society. 102: 10-15.

McQuilken, R. A. 1990. Quercus prinus L., chestnut oak. In Burns, R. M. and B. H. Honkala (tech. coords). Silvics of North America. Vol 2. Hardwoods. Agriculture Handbook 654. USDA For. Ser., Washington, DC. 
Marquis, D. A, P. L. Eckert, and B. A. Roach. 1976. Acorn weevils, rodents, and deer all contribute to oak regeneration difficulties in Pennsylvania. USDA For. Ser. Res. Pap. NE-356

Muick, P. C. 1991. Effects of shade on blue oak and coast live oak regeneration in Californian annual grasslands. In Pillsbury, N. H., J. Verner, and W. D. Tietje (tech. coords.). Proc. of a symposium on oak woodlands: ecology, management, and urban interface issues. USDA For. Ser. Gen. Tech. Rep. PSW-126.

Nowacki, G. J. and M. D. Abrams. 1997. Radial-growth averaging criteria for reconstructing disturbance histories from presettlement-origin oaks. Ecol. Monogr. 67: 225-249.

Oliver, C. D. and B. C. Larsen. 1996. Forest stand dynamics. John Wiley \& Sons, New York, NY.

Parker, G. R., D. J. Leopold, and J. K. Eichenberger. 1985. Tree dynamics in an old-growth, deciduous forest. For. Ecol. Manage. 11: 31-57.

Peet, R. K., and O. L. Loucks. 1977. A gradient analysis of southern Wisconsin forests. Ecology 58: 485-499.

Phares, R. E. 1972. Growth of red oak (Quercus rubra L.) seedlings in relation to light and nutrients. Ecology 52: 669-672.

Rentch, J. S., and Hicks, R. R., Jr. In press. Nutrient fluxes for two small watersheds: sixteenyear results from the West Virginia University Forest. W. Va. Univ. Agric. Exp. Stn. Bull. No. 724.

Rogers, R. 1990. Quercus alba L., white oak. In Burns, R. M. and B. H. Honkala (tech. coords.). Silvics of North America. Vol 2. Hardwoods. Agriculture Handbook 654. USDA For. Ser., Washington, DC.

Runkle, J. R. 1990. Gap dynamics in an Ohio Acer-Fagus forest and speculations on the geography of disturbance. Can. J. For. Res. 20: 632-641.

Russell, E. W. 1980. Vegetational change in northern New Jersey from precolonization to the present: a palynological interpretation. Bull. Torry Bot. Club 107: 432-446.

Sander, I. L. 1990a. Quercus rubra L., northern red oak. In Burns, R. M. and B. H. Honkala (tech. coords.). Silvics of North America. Vol 2. Hardwoods. Agriculture Handbook 654. USDA For. Ser., Washington, DC

Sander, I. L. 1990b. Quercus velutina Lam., black oak. In Burns, R. M. and B. H. Honkala (tech. coords.). Silvics of North America. Vol 2. Hardwoods. Agriculture Handbook 654. USDA For. Ser., Washington, DC. 
Savill, P. S. 1991. The silviculture of trees used in British forestry. C.A.B. International, Wallingford, U.K.

Sears, P. B. 1925. The natural vegetation of Ohio. Ohio J. Science 25: 139-149.

Society of American Foresters. 1993. Task force report on sustaining long-term forest health and productivity. Society of American Foresters, Bethesda, MD.

Smith, D. W. 1993. Oak regeneration: the scope of the problem. Pp. 40-52 In Loftis, D. L. and C. E. McGee, eds. Oak regeneration: serious problems, practical recommendations. USDA For. Ser. Res. Pap. NE-356.

Smith, K. T. and E. K. Sutherland. 1999. Fire-scar formation and compartmentalization in oak. Can. J. For. Res. 29: 166-171.

Sprugel, D. G. 1991. Disturbance, equilibrium, and environmental variability: what is 'natural' vegetation in a changing environment? Biol. Cons. 58: 1-18.

Trimble, G. R, Jr. 1975. Summaries of some silvical characteristics of several Appalachian hardwood species. USDA For. Ser. Gen. Tech. Rep. NE-16.

Tyrrell, L. E., G. J. Nowacki, T. R. Crow, D. S. Buckley, E. A. Nauertz, J. N. Niese, J. L. Rollinger, and J. C. Zasada. 1998. Information about old-growth for selected forest type groups in the eastern United States. USDA For. Ser. Gen. Tech. Rep. NC-197.

USDA 2001. Forest Inventory and analysis data base and retrieval system. USDA For. Ser. <http://www.srsfia.usfs.msstate.edu>

Wade, D. D., B. L. Brock, P. H. Brose, J. B. Grace, G. A. Hock, and W. A. Patternson III. 2000. Fire in eastern ecosystems. Chapter 4 In Brown, J. K. and J. K. Smith, eds. Wildland fire in ecosystems: effects of fire on flora. USDA For. Ser. Gen. Tech. Rep. RMRS-42 Vol. 2.

Watts, W. A. 1979. Late quaternary vegetation of central Appalachia and the New Jersey coastal plain. Ecol. Monogr. 49: 427-469.

Webb, T., III. 1988. Eastern North America. Pp. 385-413 In Huntley, B and T. Webb, III, eds. Vegetation history. Kluwer Academic Publishers, Boston, MA.

Weitzman, S. and G. R. Trimble. 1957. Some natural factors that govern the management of oaks. USDA For. Ser. Res. Pap. NE-88.

Wolff, J. O. 1996. Population fluctuations of mast-eating rodents are correlated with production of acorns. J. Mammal. 77: 850-856. 
Table 1.1. Percent total hardwood growing stock and percent average annual removals by volume for oak species groups. Source is USDA Forest Service FIA data (2001) from most recent statewide inventory, Tables 12 and 20.

\begin{tabular}{|c|c|c|c|c|c|c|c|c|}
\hline \multirow[b]{2}{*}{ State } & \multicolumn{2}{|c|}{ Select white oak ${ }^{1}$} & \multicolumn{2}{|c|}{ Select red oak ${ }^{2}$} & \multicolumn{2}{|c|}{ Other white oak ${ }^{3}$} & \multicolumn{2}{|c|}{ Other red oak ${ }^{4}$} \\
\hline & $\begin{array}{l}\text { growing } \\
\text { stock }(\%) \\
\end{array}$ & $\begin{array}{c}\text { removals } \\
(\%)\end{array}$ & $\begin{array}{l}\text { growing } \\
\text { stock (\%) }\end{array}$ & $\begin{array}{c}\text { removals } \\
(\%)\end{array}$ & $\begin{array}{l}\text { growing } \\
\text { stock }(\%) \\
\end{array}$ & $\begin{array}{c}\text { removals } \\
(\%)\end{array}$ & $\begin{array}{l}\text { growing } \\
\text { stock }(\%) \\
\end{array}$ & $\begin{array}{c}\text { removals } \\
(\%)\end{array}$ \\
\hline Kentucky & 14 & 17 & 6 & 8 & 9 & 9 & 14 & 21 \\
\hline Ohio & 9 & 16 & 6 & 9 & 3 & 6 & 7 & 12 \\
\hline Pennsylvania & 6 & 7 & 12 & 19 & 8 & 10 & 5 & 10 \\
\hline Virginia & 15 & 18 & 8 & 7 & 13 & 7 & 14 & 18 \\
\hline West Virginia & 9 & 7 & 9 & 14 & 10 & 8 & 10 & 12 \\
\hline Average & 11 & 13 & 8 & 11 & 9 & 8 & 10 & 14 \\
\hline
\end{tabular}

${ }^{1}$ Select white oak $=$ primarily white oak

${ }^{2}$ Select red oak $=$ primarily northern red oak

${ }^{3}$ Other white oak $=$ primarily chestnut oak and post oak

${ }^{4}$ Other red oak $=$ primarily black oak, scarlet oak, and southern red oak 
Figure 1.1. Location map of five oak-dominated, old growth study sites.

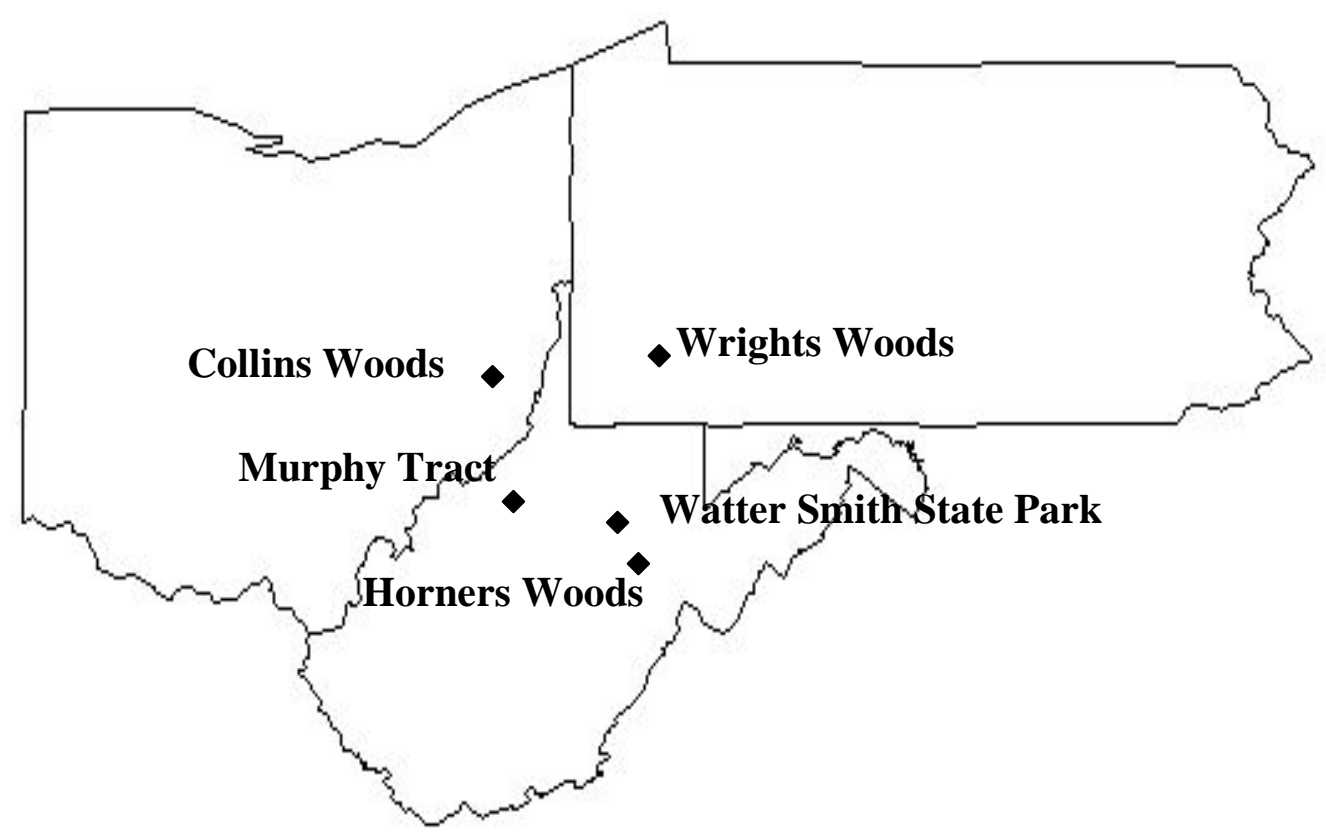


CHAPTER 2

\title{
Presettlement forest COMPOSITION
}

\begin{abstract}
Witness tree tallies from early land surveys show that presettlement forests in eastern Ohio, southwestern Pennsylvania, and north central West Virginia were oak-dominated forests. Quercus alba was dominant by a large margin, at minimum twice as abundant as $Q$. velutina, the second ranked species. Acer saccharum and Fagus grandifolia were among the top ten ranked species at each site; however their importance value was consistently less than one-third the value for $Q$. alba. Quercus rubra, Q. prinus, Castanea dentata, and Acer rubrum were relatively minor components of presettlement forests, rarely ranked among the ten most abundant tree species. The one area for which diameter-distribution data are available shows that oaks were well distributed among all but the smallest size classes, suggesting that oak replacement was a stable feature of these forests. Cluster analysis of presettlement and modern, FIA data show a clear separation by historical period. Modern inventories consistently show a significant decline in $Q$. alba abundance and a large increase for A. rubrum. Other early successional species such as Prunus serotina, Liriodendron tulipifera, and Fraxinus americana showed large increases, although this trend varied somewhat among the five study sites. The species composition of presettlement forests suggests a highly variable disturbance regime in which a variety of species with different life history strategies, disturbance tolerances, and growth requirements shared overstory position. Changes in species dominance over the time period reviewed suggest that
\end{abstract}


$20^{\text {th }}$ century reduction in fire frequency resulted in reduced oak abundance and accelerated recruitment of fire intolerant species. 


\section{Introduction}

The nature of the eastern deciduous forest prior to European settlement has long intrigued forest historians and ecologists, and has a prominent place in popular culture. Popular belief held that the earliest settlers of eastern North America found everywhere an unbroken, primeval forest of gigantic proportions. Joseph Martin, (1835) in the Gazetteer of Virginia and the District of Columbia, thought the forest so vast that it could never be conquered, and "must remain for ever in its primitive forest." Lewis (1998) reports the remarks of a party of Virginians led by Thomas Jefferson's father, when they viewed Canaan Valley, West Virginia from the top of Cabin Mountain in 1746: "Did not see a plain big enough for a man to lie on nor a horse to stand." In the 1850s, David Hunter Strother's (Porte Crayon) accounts and illustrations for popular magazines helped perpetuate the notion that western Virginia was exotic, threatening, and impenetrable. The 1908 report of the West Virginia Conservation Commission noted that when white men first came into the state "it was all forest except a few cliffs and rocky peaks, and two or three old fields where Indians had probably cultivated corn" (Maxwell 1908). The report also described the successional status of these forests:

"The forests had reached a state of equilibrium. The growth was neither increasing nor diminishing, but was at a standstill. The young growth coming on and the old trees dying and falling balanced each other. Such is the condition in old, mature forests where nothing disturbs the balance of forests."

Paleo-Indians arrived in the upper Ohio Valley as early as 14,000 years ago, and the region was continually occupied and used by the time the first Europeans arrived in the 1600s (Yarnell 1998; Adovasio and Pedler 2000). Native American use of fire to prepare land for agriculture, clear forests of understory vegetation and encourage grass, maintain a network of 
trails, and drive game, for example, have been extensively documented both by early European visitors (Lederer and Talbot 1672; Bushnell 1907) and contemporary researchers (Delcourt and Delcourt 1998; Bonnicksen 2000). Fire frequency, in turn, influenced the species composition of presettlement forests. Until the advent of horticulture (2000 years ago), only 10 percent of the wood preserved as charcoal in archeological sites represents species favored by disturbed environments. From this period on, the proportion of wood charcoal from pine (Pinus spp.), tulip-poplar (Lirodendron tulipifera L.), and cane, for example, steadily increased to a maximum of 50 percent (Chapman et al. 1982).

Native American use of fire to create openings for agriculture and to clear forests of understory vegetation are reflected in early descriptions of forest structure. Beverley (1971), writing in 1722, recounted early explorers' descriptions of the forests near the present-day West Virginia-Virginia border: "they found large level plains...and fine savannahs three or four miles wide." Seeking to entice settlers to his land along the Kanawha and Ohio Rivers, George Washington praised them as containing "most excellent meadows, many of which...are, in their present state, almost fit for the scythe" (Rice 1970). Bromley (1935) described the impact of native American use of fire on forest structure in southern New England: "on one subject, all are in accord and that is the observation that the original forest was, in most places, extremely open and park like, due to the universal factor of fire, fostered by the original inhabitants." Maxwell (1910) cited a similar condition for precolonial forests of Virginia: "freedom from undergrowth was one of the most notable features of the original woods of Virginia." Delcourt and Delcourt (1998) concluded that native American use of fire was a significant component of a total disturbance regime that resulted in a heterogeneous mosaic of different vegetation types, some of which included fire adapted species, and others of which included fire-intolerant species. 
Contemporary evidence for the composition of the presettlement forest comes from three sources. 1) Pollen analysis has been used to chronicle changes in genus-level composition following the retreat of Pleistocene glaciers. These studies have reviewed both long-term trends over thousands of years (Watts 1979; Davis 1981; Delcourt and Delcourt 1987; Webb 1988), and the more recent historical era from presettlement to the present (Russell 1980). 2) Old-growth remnants that are representative of the presettlement forest have been extensively studied, using both living and dead stems (e.g., Henry and Swan 1974); one list of these studies contains 749 entries (Nowacki and Trianosky 1993). An obvious limitation of these studies is the rarity and small size of remaining old-growth sites in the East (Davis 1996). 3) In the East, the surveyor did not always precede the plow, but early land surveys do contain valuable information about forest composition before large-scale forest clearing began. They also have the advantage of having been written in the field. Because property was involved, surveys were intended to last, and thus to a certain extent, they are repeatable. Reconstructions of forest composition in Ohio (Sears 1925), northwest Pennsylvania (Lutz 1930a), New England (Bromley 1935; Day 1953), and Michigan (Bourdo 1956) proved the utility of using early land surveys and witness tree records. More recent papers have used early records to quantify species composition and abundance (Lorimer 1977), vegetation-site relationships (Abrams and McCay 1996), disturbance regimes (Canham and Loucks 1984; Loeb 1987), and landscape heterogeneity (Delcourt and Delcourt 1996).

Reconstruction of the original forest composition and the dynamics of that forest are not entirely academic questions. Historically, classifications of forest types or associations by Braun (1950) and Kuchler (1964) used climate and physiography to arrive at the potential natural vegetation, defined as "the vegetation that would exist today if man were removed from the 
scene" (cited in Eyre 1980). Concern for the future of eastern oak (Quercus spp. L.) forests and management strategies for encouraging oak regeneration are based, in part, on evidence (or an assumption) that current forests were historically oak-dominated, and naturally maintained in the presettlement landscape. However, in some areas, particularly those around the periphery of the central hardwood forest region, oak stands are more recent and owe their origin to 50-100 years of influence by European settlers (Crow 1988; Lorimer 1993). Forest clearing in the midAtlantic region to produce charcoal for the early iron industry (Schnur 1937; Abrams 1992), succession of old-fields to pine and then to oak (Lorimer 1993), and fire suppression in the oak savannahs of the Midwest often created forests that were quite unlike those the first European arrivals saw. More recently, oak abundance has been augmented by elimination of American chestnut [Castanea dentata (Marsh.) Borkh.] as a canopy tree (Stephenson et al. 1993). Thus, what today appears "natural," may be quite temporary and recent (cf. Sprugel 1991). Finally, conservation and restoration of old growth require a baseline target (Hamel and Buckner 1998). If this target proves to be extremely rare and unstable, and/or "unnatural," however that is defined, then restoration effects will require considerable cultural intervention (Hamel and Buckner 1998).

The objective of this chapter is to use records of witness trees of early land surveys and property transfers to reconstruct county-level forest composition at the time of earliest European settlement. Witness tree records from five areas of West Virginia, Pennsylvania, and Ohio are reviewed, based on the locations of the surviving old-growth stands that are the subject of this dissertation. Results are then compared to modern data on composition from USDA Forest Service inventories. The bulk of the surveys used in this study were of public land, owned either by the Virginia colonial government, in the case of West Virginia and Pennsylvania, or by the 
Federal government, in the case of Ohio. While it was true that homesteading did not always wait for legal claims, these surveys in the main preceded large-scale European settlement, forest clearing, and other forms of human disturbance (Loeb 1987). Thus these records are a valuable database, and constitute one of the few quantitative sources of tree species composition and abundance over relatively large areas.

Methods

Presettlement forest composition. Presettlement-era forest composition was derived from tallies of witness trees from property deeds, early metes and bounds warrant surveys, and township surveys (Figure 2.1). For Lewis County, West Virginia (site of Horners Woods), property deeds covering a 3-year period between 1817-1819 were reviewed. Only deeds from the southwestern portion of the county were used, including the drainages of Skin Creek, Leading Creek, Stonecoal Creek, and the West Fork River above the town of Weston. For sites in Ritchie County, West Virginia (Murphy Tract), Harrison County, West Virginia (Watter Smith State Park), and Washington County, Pennsylvania (Wrights Woods), metes and bounds warrant surveys from Survey Book 1 of the respective counties were the data source. Warrants were for public land that had not been previously patented. They were issued by the Virginia land office upon payment of a fee, and allowed the warrantee to locate a tract, have it surveyed, and return the survey to the land office, after which a patent was issued (Sipe 1965). Fourhundred acre tracts were conveyed to homesteaders based on a 1777 provision by the Virginia General Assembly (Core 1974). However, many early warrants were issued to land speculators who never saw the land, and intended only to encourage settlement and sell property. 
For the time period reviewed, Ritchie County was still part of Harrison County, and Washington County then included what is now Greene County. Whenever possible, I selected only those surveys that were in the vicinity of the respective old-growth study sites. For Ritchie County, warrant maps by Jeremiah Williams, Edward Jackson, William Walden, and John Ferry in the Bond Creek, Bone Creek, Hughes River, and Little Kanawha River drainages were used. For Harrison County, I used surveys by Hezikiah Davidson, Henry Fink, George Arnold, and Stephen Sherwood along Ten-mile, Mill Creek, Sycamore Creek, Lost Creek, and West Fork River. Finally, for Washington County, tree data was taken from warrant maps of John Hoges along Ten-mile, Pigeon Creek, Peters Creek, Raccoon Creek, and Chartiers Creek.

In Belmont County, Ohio, witness trees were tallied from 1786 federal General Land Office (GLO) township surveys. This area, the Old Seven Ranges of the Northwest Territory, was the first in the nation to be systematically laid out using a grid pattern of six-mile by six-mile townships and one-mile by one-mile sections (White 1983). The township lines of Kirkwood Township, containing present-day Collins Woods, were established in 1786, and section lines were completed in 1804; a total of 84 miles of line was surveyed. When township lines were established, surveyors were instructed to blaze two or more bearing trees closest to each corner post, and to mark all station trees that intersected the line. Two additional trees were marked later when section lines were established. Tree species and estimated diameters were recorded in surveyor's logs, along with topographic information and descriptions of forest quality (White 1983).

Sample size adequacy. The number of surveys tallied for each county ranged between 74-130, and small sample size is a potential source of error in estimating presettlement forest composition. The acreage of the survey often was often noted, but is of little use in guiding an 
evaluation of minimum survey-sample size. For example, over 100 surveys in Ritchie County, WV were perfectly rectangular 1000-10,000 acre plots that were each identified by only four witness trees. To check for adequate sample size, I first constructed species-area curves using PC-ORD ${ }^{\circledR}$ software (McCune and Mefford 1997). This procedure yields a jackknife estimator (Palmer 1990), which indicates the number of sample plots at which species richness and community similarity between sample plots converge. Above this value, little is gained in species richness by increasing sample size. Using the jackknife estimator, I randomly selected that number of plots from the total sample and tallied importance values (IV) for each species. I then computed percent similarity (Ludwig and Reynolds 1988) values between the subsample and the complete sample:

$$
\text { Percent similarity (PS) }=2 * w /(a+b) * 100
$$

where $w$ is the sum of the shared IV's, and a and b represent IV's abundances of all surveys for each county and the subsample, respectively. Results show that 23-30 land surveys at each location were sufficient to yield PS values greater than $98 \%$. This suggests that species richness and community similarity were independent of the sample size when greater than 30 surveys were tallied, and that a more extensive sample would not have improved the estimate of species composition.

Contemporary forest composition. Present-day forest composition was derived from the USDA Forest Service Forest Inventory and Analysis (FIA) database (USDA 2001). Data were compiled by county. However, because of the small number of FIA sample plots in Washington County and Harrison County, these two counties were combined with adjacent counties, Greene County and Doddridge County, respectively to increase sample size. I used Table 10 (live trees on timberland by species and diameter class) from the FIA database with two 
modifications. First, the physiographic class was limited to xeric, xeromesic, and mesic to eliminate wetter sites. Second, because of a bias against the smallest trees in the presettlement surveys (discussed below), only trees $\geq 12.7 \mathrm{~cm}$ dbh (5 in) were used.

Because the FIA tree classification system focuses on commercial timber, some species richness information is lost. For example, the "other red oak" group includes black oak and scarlet oak, (Quercus velutina Lam., Q. coccinea Meunchh., respectively). "Soft maple" includes red maple and silver maple (Acer rubrum L., A. saccharinum L.). Other broader groupings include "other soft hardwood," "other hard hardwood," and "noncommercial." Table 2.1 shows the more common species in these groups. To compare presettlement and current forest composition, I reclassified presettlement witness tree tallies using the FIA classification system and relativized the data to an importance value (IV) based on abundance by county:

IV species $_{\mathrm{n}}=\sum$ occurrences species $_{\mathrm{n}} / \sum$ occurrences all species $* 100 \%$

Data analysis. I used the Analysis of Variance (ANOVA) of ranked data to compare species ranking between presettlement-era sites. Ranking allows comparison of data in which a few species occur in large numbers (e.g., white oak), and a large number of species occur in small numbers (e.g., cucumber tree). This technique also avoids problems associated with comparison of nonparametric, ordinal data. I used cluster analysis (PC-ORD ${ }^{\circledR}$ software, McCune and Mefford 1997) to check for similarity between current and former forest composition. Cluster analysis is an agglomerative method of numerical classification that groups points (plots) in mathematical space according to ecological "distance," or community similarity (Kent and Coker 1995). The technique starts with individual plots and combines them progressively until all the plots are in one group. I used the Euclidean distance as the distance measure between plots, and Ward's method of linkage, a technique based on minimizing the in-cluster variance. 
There are no statistical comparisons for this technique, although the degree of dendrogram chaining does indicate the robustness of the procedure. Dendrograms that are highly chained involve the repetitive addition of a single plot to an increasingly large group and are of little value in revealing compositional differences between plots (McCune and Mefford 1997). I used a $25 \%$ chaining as a cutoff value for acceptable cluster analysis.

Results

Surveyor bias in presettlement land surveys. For the purposes of using witness trees in forest reconstruction, the most important question revolves around bias in tree selection, and thus the randomness of the sample. For example, were bearing trees actually those closest to the surveyed corner, and selected without regard to species, size, or condition? Bourdo (1956) summarized sources of potential bias in tree selection for bearing trees in the presettlement land surveys. While his analysis applied to GLO surveys in Michigan, similar concerns apply to early metes and bounds surveys in West Virginia and Pennsylvania where procedures were less standardized and supervised. Many colonial surveys were irregular in shape and size; few can be relocated and verified using modern statistical tests of bias (Bourdo 1956; Lorimer 1977; Loeb 1987).

No corner tree specifications were included in the 1804 GLO instructions to surveyors, although wooden posts had to be three inches in diameter (White 1983). In 1804, bearing trees were defined as those that are "soundest and most thrifty in appearance, and of the size and kinds of trees which experience teaches will be the most permanent kind" (cited in Bourdo 1956). In 1846, the definition specified that trees "be alive and healthy and not less than 5 inches in 
diameter," and Bourdo (1956) hypothesized that this specification guided earlier field-work as well. Other sources of bias include tree selection favoring 1) trees with loose bark that could be easily knocked off and inscribed, 2) large trees with symmetrical trunks, 3) uncommon trees that could be easily relocated during subsequent resurveys, and 4) long-living and rot-resistant trees. Lutz (1930b) reported that some Pennsylvania surveyors preferred black gum (Nyssa sylvatica Marsh.) due to its low economic value a low likelihood of being harvested. Bourdo (1956) concludes that there is little doubt some bias existed, but he adds that the primary question was not whether bias was present, but whether it was important.

Statistically significant bias in witness tree selection has not been found where surveys have been reconstructed (McIntosh 1962; Siccama 1971; Delcourt and Delcourt 1974, 1996; Lorimer 1977). Several factors suggest that bias was not a source of significant error in this study. First, colonial Virginia surveyors were relatively well educated compared to the general populace, and enjoyed wealth, social status, and political power. Many held the position for life. Surveyors were officers of the state, and claims on public land by warrant could only be made after a survey by a commissioned surveyor or his assistant (Hughes 1979). While none of these factors necessarily exclude bias, they do imply a degree of professionalism. Second, the trees identified, both by species and potential size, suggest reasonable surveying standards were followed. Land surveys identify a surprisingly large number of species, suggesting that early surveyors were skilled in tree identification (Spurr 1951) (Table 2.2). This is all the more notable since spring and fall (leaf-off) were preferred surveying times to avoid snakes (Hughes 1979). Species abundances are within reason in terms of their current distributions. For example, the respective abundances of black gum, identified as a preferred species by Lutz (1930), are similar for presettlement and FIA tallies (Tables 2.2, 2.3). 
Of necessity, there was probably some bias against the smallest trees; they had to be big enough to either blaze without killing them in the case of metes and bounds surveys, or to inscribe for township surveys. Nevertheless, dogwood (Cornus florida L.), a rough-barked understory tree that rarely gets very large, appeared quite frequently in presettlement surveys. It was the $4^{\text {th }}$ ranked tree named in Washington County surveys, $7^{\text {th }}$ in nearby Fayette County, Pennsylvania (Abrams and Downs 1990), and $5^{\text {th }}$ in Ritchie County (Table 2.2), ranking above a number of species termed "preferred" by Lutz (1930). Other understory trees such as musclewood (Carpinus caroliniana Walt.), eastern hophornbeam [Ostrya virginiana (Mill.) K. Koch], serviceberry [Amelianchier arborea (Michx.) Fern], and red bud (Cercis canadensis L.) were named frequently enough to suggest that proximity to a surveyed corner, rather than species or size preferences, guided selection of witness trees.

Presettlement forest composition and structure. Based on witness tree data from early land surveys and deeds, presettlement forests of the five study areas were very similar, and consistently oak-dominated (Table 2.2). Percent similarity, using only the ten most abundant species, yielded an average value of $95 \%$. ANOVA revealed no significant differences of species rankings between sites $(\mathrm{F}=0.187, \mathrm{p}=0.945)$. White oak (Quercus alba L.) was the dominant tree by a large margin, twice as abundant as the second ranked species. At four of the five sites, black oak was the second most abundant species, followed by hickories (Carya spp.), and yellow-poplar (Lirodendron tulipifera L.). Sugar maple (Acer saccharum Marsh.) and American beech (Fagus grandifolia Ehrh.) were also among the top ten ranked species at each site, however, their importance was consistently less than one-third the value for white oak. Red maple ranked $10^{\text {th }}$ on average. 
Several species were notable by their low importance or absence in presettlement surveys. American beech was rare in Washington County surveys, ranking $17^{\text {th }}$ out of 28 tree species (IV $=1.1)$; for the other counties, its average rank was $5^{\text {th }}$. Northern red oak $($ Quercus rubra L.), chestnut oak (Q. prinus L.), and American chestnut were all relatively minor components of these forests. The highest ranking for northern red oak occurred at Washington County, where it was seventh out of a total of 28 species $(I V=2.9)$. For Harrison County, red oak ranked $19^{\text {th }}$ of $23(\mathrm{IV}=0.5)$. American chestnut ranked among the top ten species at only one location, and had an average rank of 13. Pines were generally not identified to species by land surveys and formed a relatively small component of these forests. Notably, eastern hemlock (Tsuga canadensis (L.) Carr.] did not appear in any of the surveys reviewed. The absence of hemlock is surprising since metes and bounds surveys often followed natural boundaries such as streams where this species would most likely occur.

Some characteristics of the size structure of the Belmont County, Ohio forest can be estimated using diameter records of corner and station trees from the township surveys (Figure 2.2). Understory trees (e.g., dogwood) composed only $3 \%$ of the total, however, as discussed above, surveyors probably tended to favor larger trees to facilitate inscription of boundary notations (Bourdo 1956). Thus, the shape of the overall distribution may be misleading. Depending on the actual abundance of small diameter trees, the size distribution curve could potentially be normal, reverse-J shaped, or rotated sigmoid in shape (Goff and West 1975). Oaks were well distributed among all but the smallest size classes; for example, $73 \%$ of the white oaks occurred in the $35-55 \mathrm{~cm}$ classes, while red oaks tended to be somewhat larger. The largest size classes (> $90 \mathrm{~cm}$ ) contained white oak, black oak, black walnut, and American chestnut. Among the largest trees were a white oak, American chestnut, and buckeye (Aesculus octandra Marsh.), 
each with an estimated diameter of $127 \mathrm{~cm}$ (50 in.). In contrast, shade tolerants such as maples and beech, and intermediates [e.g., hickories, white ash, (Fraxinus americana L.)] were concentrated in the $25-55 \mathrm{~cm}$ size classes and none were larger than $65 \mathrm{~cm}$ in diameter.

\section{Comparison of presettlement-era and contemporary FIA forest composition.}

Groupings from cluster analysis of forests for the two periods linked according to the time of survey (Figure 2.3). The final cluster linking presettlement to FIA data occurred with only $4 \%$ of the information remaining, indicating very high dissimilarity between forests of the two historical periods.

White oak and red maple IV's showed the largest differences between the two historical periods (Table 2.3). White oaks dropped from an average rank of $1^{\text {st }}(\mathrm{IV}=33.7)$ in presettlement forests to $6^{\text {th }}(I V=7.3)$ at present. Red maple showed the opposite trend, increasing from $10^{\text {th }}$ in older forests to $2^{\text {nd }}$ today. Because the FIA data used in this comparison are limited to stems > $12.7 \mathrm{~cm} \mathrm{dbh}(5 \mathrm{in}$.$) , the increased abundance of this species is probably underrepresented.$ Hickories and sugar maple showed little overall change in rank. Beech showed a slight decline in four counties, and a considerable drop in Lewis County, where it decreased from $2^{\text {nd }}(\mathrm{IV}=$ $14.8)$ in the presettlement surveys, to $11^{\text {th }}(\mathrm{IV}=2.5)$ in 1989. Yellow-poplar showed large changes in Harrison County and Lewis County, increasing from presettlement rankings of $7^{\text {th }}$ and $6^{\text {th }}$ to $4^{\text {th }}$ and $1^{\text {st }}$, respectively. The increased importance of the large group, "other soft hardwoods," in Belmont County, Washington County, and Harrison County illustrates the shortcomings of using the FIA species-groupings to analyze species composition. According to species IV data from Iverson et al. (1999) based on all stems $\geq 2.54 \mathrm{~cm} \mathrm{dbh}$, the main component of "other soft hardwoods" is black cherry (Prunus serotina Ehrh.), with IV's of 8, 24, and 14 for 
the three counties, respectively. Based on the same data, the large value for "other hard hardwood" in Lewis County is largely due to the high IV (13) for dogwood.

\section{Discussion}

Oak domination of presettlement forests. The presettlement forests of these five counties were consistently dominated by one tree species—white oak. This species ranked $1^{\text {st }}$ by a large margin in all five counties examined, more than twice the value of the nearest competitor. The dominance of white oak is consistent with other studies that used witness trees to reconstruct original forest composition. White oak was the most common species in witness tree tallies of George Washington's 1748-1752 surveys across a variety of landforms in eastern West Virginia (Spurr 1951). Sears (1925) prepared a map of the natural vegetation of Ohio from the GLO survey notes, and classified Belmont County as oak-dominated, with white oak, black oak, and hickory the most common species. Similar results were found in Fayette County in southwestern PA (Abrams and Downs 1990), the Nittany Valley of central Pennsylvania (Nowacki and Abrams 1992), the Ridge and Valley section of West Virginia (Abrams and McCay 1996), southern Illinois (Leitner and Jackson 1981), and east New Jersey and southeastern New York (Loeb 1987)

Early qualitative descriptions reinforce the results of witness tree tallies. White oak dominated presettlement forests in much of southwestern Pennsylvania, with much smaller components of beech and other mesophytic hardwoods according to accounts by Michaux (1853) and Jenning (1927). In an 1854 description of the Great Kanawha Estate, a 100,000 acre uncut tract in Putnam County, West Virginia, white oak was the most abundant species (Simpson 
1860). Brooks (1910) estimated that white oak comprised 30 percent of the yet uncut hardwoods of West Virginia in 1910. Other oaks (chestnut oak, red oak, black oak, scarlet oak, etc.) together accounted for only 15 percent, along with yellow-poplar (18\%), chestnut (12\%), maple (5\%), and beech (5\%). Braun (1950) cites reports of original forest composition in northeastern Kentucky and near Gallipolis in southeastern Ohio. White oak was dominant on the hillside plots, second to beech in the valley plots, and most abundant overall. Crandall (1876, cited in Braun 1950) described this species as having "a wider range and greater development in numbers than any other species. In size it ranks with the largest of the hard wood trees, often reaching a diameter of three and a half feet." Where present, red oak "reached proportions scarcely less imposing than white oak or black oak," but black oak was consistently more abundant than red oak.

Forest disturbance and changes in species abundance. Species distributions in presettlement forests were influenced largely by the interaction of climate, soils, landform, and fire frequency (Sears 1925; Kline and Cottam 1979; Abrams 1992; Lorimer 1993; Abrams and McCay 1996; Ruffner and Abrams 1998). Since European settlement, major changes in regional species composition have been linked to forest clearing, chestnut blight, and reduced fire frequency. In central Pennsylvania, increases of northern red oak, chestnut oak, and red maple were partially attributed to the elimination of American chestnut by the chestnut blight (Abrams and Ruffner 1995; Ruffner and Abrams 1998). Similar dynamics were noted by Keever (1953) and Stephenson (1986) in North Carolina and Virginia, respectively, although no single species consistently filled the vacancies created by chestnut blight (Stephenson et al. 1993). Replacement generally occurred by two means (Braun 1950; Stephenson et al. 1993). Where chestnut densities were low, canopy vacancies were filled by existing canopy species; where 
chestnut densities were high, a more complex process occurred that involved the emergence of other species (e.g., red maple) not previously important in the canopy.

In this study, red oak IV from FIA tallies slightly increased in four counties, and decreased in one. Chestnut oak showed a similar trend, although neither species showed an appreciable change in rank. Chestnut was present but not abundant, and the absence of larger increases for red oak and chestnut oak between presettlement and modern eras may be due to low levels of American chestnut in these particular areas. Its highest ranking was $7^{\text {th }}$ at Belmont County and lowest $\left(23^{\text {rd }}\right)$ in Washington County. Brooks' (1910) review of the original forest composition of West Virginia estimates chestnut comprised about 12\% of the uncut forests, but does not give it much prominence for the three West Virginia counties in this study, and the witness tree tallies bear this out (average rank, $12^{\text {th }}$ ).

Other studies have also linked oak abundance to repeated harvesting during the $1800 \mathrm{~s}$ and early 1900s (Crow 1988; Abrams 1992; Lorimer 1993). For the five counties of this study, forest clearing for agriculture and local use were probably largely completed before the onset of large-scale commercial logging operations that typified the economies of the Allegheny Plateau and eastern mountains of West Virginia at the turn of the century (Lewis 1998). In southwestern Pennsylvania and eastern Ohio, some intensive logging occurred in the early-mid 1800s in connection with charcoal production for iron foundries (Pearse 1876; McKelvey 1903). Pearse (1876) noted that the first iron foundry west of the Allegheny Mountains was established in Washington County, PA (1777-1784), and he reported 16 charcoal furnaces in Fayette County between 1805-1835, and 28 furnaces in Allegheny County by 1840, although he does not provide figures for Washington County. These were not small operations, even by current standards. A typical furnace required harvesting 100-200 ha of forest each year (Schnur 1930; Abrams and 
Nowacki 1992), and iron companies typically held tracts of over 4000 ha of forest land (Moreland 1940). In nearby Monongalia County, West Virginia, Moreland (1940) reported a community of 500 people associated with producing charcoal and smelting iron ore at one furnace; thousands more were involved in mills and foundries that produced nails and other finished products. For the purposes of making charcoal, stem quality was of little importance, and thus forests were clearcut on 20-40 year rotations (Stout 1933; Ruffner and Abrams 1998). Fires often followed. Charcoal production peaked in the 1850s, when coke was substituted for charcoal (Moreland 1940), but the impact of this industry on forests was considerable. The coppice nature of the resultant forests favored species, such as red oak, that readily sprout from smaller stumps, and that thrive in post-disturbance environments where light levels are high and competition is low.

The iron-charcoal industry may also account for the low abundance of beech in modern forests in southwestern Pennsylvania, where it was ranked $15^{\text {th }}$ out of 16. (Table 2.3). This species readily produces sprouts and root suckers, but because of its thin bark and shallow roots, it is highly susceptible to fire injury (Iverson et al. 1999). Beech has been identified as a preferred species for making charcoal used in iron ore smelting (Core 1974), and Carvell (pers. comm.) cited this as one reason for its current low ecological importance in areas of north-central West Virginia. However, the low levels of beech in the 1786 witness tree tallies predate the most intense period of charcoal-iron production, and thus other factors are also probably involved.

In Ritchie County and adjacent counties in West Virginia, the production of cross ties for railroads, and later, timbers for mines, was spurred by the opening of the B \& O Railroad between Clarksburg and Parkersburg in 1857. The extent of this industry was considerable; an 
1882 map of the distribution of forests in West Virginia showed a $32 \mathrm{~km}$ wide swathe of cleared forest across Harrison, Doddridge, and Ritchie Counties centered on the railroad route (cited in Lewis 1998). Brooks (1910) also reported stave mills and shingle mills in Ritchie County in the 1870s. Livestock production in this region became the principal supplier for eastern markets in the antebellum era, and livestock grazing in forests and cutover lands and seasonal burning constituted additional disturbances to forests of the region. Lewis (1998) reports over 9000 head of cattle shipped from Pennsboro, Ritchie County, in 1875, and that the National Pike (U.S. Route 40, through southwestern Pennsylvania) was often "choked with livestock being driven to eastern markets." Farmers routinely burned the forest floor to reduce underbrush, curb parasites, and increase grasses for grazing (Lewis 1998). By 1910, Brooks described the forest condition of the county: "all of the forests remaining in the county have been culled, except for a few small boundaries," and in the eastern portion of the county, "the percentage of cleared land is higher [than] farmer's woodlots."

Large scale commercial wood industry came to Lewis County even later in the 1800 s. Large numbers of yellow-poplar rafts were shipped down the West Fork River 1875-1890 to Clarksburg, Morgantown, and Pittsburgh. Brooks reported a large oak export business in the southeastern part of the county, and another company that milled 33 million board-feet in 1888 . Like Ritchie and Harrison County, Lewis County had no extensive uncut forests remaining by 1911, and the 100,000 acres of woodlots had been extensively cutover (Brooks 1910).

In summary, the counties of this study did not experience the massive operations of the eastern mountains of West Virginia and elsewhere, where larger band mills processed over one million board-feet each day. Nevertheless, the pattern of extensive forest clearing, fires, and grazing of livestock occurred there, only over a somewhat longer time period, and at least for a 
time, it was more in keeping with local economies. These practices created a highly disturbed environment that, elsewhere (Orwig and Abrams 1994; Abrams and McCay 1996; Abrams and Ruffner 1995) were highly favorable to oak establishment. For these five study sites, however, red oak and chestnut oak showed little appreciable change, while white oak showed a significant decline. In contrast, early successional species such as red maple, yellow-poplar and "other soft hardwoods," primarily black cherry, showed significant increases.

The disturbance that best accounts for these changes is fire. Presently, the fire regime of this region is characterized by infrequent, low-intensity surface fires (Wade et al 2000). As a matter of public policy, wildfire has been criminalized, and thus they are quickly extinguished and/or limited to small areas (Pyne et al. 1996). Fire return intervals have lengthened from a few years in presettlement and settlement eras (Abrams 2000; Sutherland 1997) to the longest firefree intervals in the history of the central hardwood region (Wade et al. 2000). In the absence of recurring surface fire, large openings that were previously captured by oaks instead favor faster growing pioneer species, and fire intolerant late successional species. The shade tolerance of red maple and black cherry seedlings also resulted in large accumulations of these species in the understory, which had the effect of increasing the abundance of these species in the pool of advance regeneration, and shading out oak seedlings (Lorimer 1984; Abrams 1992, 1998).

Successional status of presettlement and contemporary forests. The successional status of the presettlement forests is suggested by the species composition and dominance trends from the witness tree data. Mid-successional species such as white oak, black oak, and hickories that have an intermediate-level tolerance of shade and competition comprised, at minimum, $48 \%$ of the trees in the five samples (Figure 2.4a). Based on the presettlement diameter distribution of Belmont County, the only sample for which size data is available, these species were also well 
distributed in the medium-larger diameter classes (Figure 2.4b). Shade tolerant species, primarily sugar maple, beech, and buckeye, made up between $20-40 \%$ of the forest structure, and intolerant species were consistently around $10 \%$. Red maple was a minor component, probably confined to streambed terraces and protected micro-environments (Lorimer et al. 1994; Abrams 1998). Individuals of both shade tolerant and shade intolerant groups also reached very large size, and by implication, great age. (The Belmont County GLO surveys cite yellow-poplar and buckeye with diameters in excess of $100 \mathrm{~cm}$ )

The compositional trends and limited size distribution data of early forests provide, by inference, an indication of broad-scale disturbance patterns in the region. The disturbance regime and the turnover of growing space were such that heterogeneous mosaic of different vegetation types coexisted (Delcourt and Delcourt 1998): shade intolerants such as yellow-poplar and black walnut could become established in large gaps and reach overstory position before closure, while shade tolerant trees could persist in the understory and reach overstory position as smaller gaps were created. However, the dominance by oaks and other intermediates suggest frequent surface fire as an additional dynamic. Fire reduced understory competition, and enabled these species to survive high mortality as seedlings, recruit to sapling-size, and eventually dominate the lower-threshold size of the overstory $(25-35 \mathrm{~cm} \mathrm{dbh})$. Finally, the presence of very large trees suggest that the rate of large, catastrophic disturbances was small enough to allow the longest lived trees of all tolerances (e.g., white oak, yellow-poplar, buckeye) to grow to large size and presumably, great age.

For current forests, the proportion of shade tolerant species is somewhat higher for two counties and slightly lower for three counties. However, the proportion of intolerants such as yellow-poplar and black cherry at minimum doubled; for two counties, shade intolerants 
increased threefold (Figure 2.3). This steep decline in the contemporary abundance of intermediate-tolerance trees such as oak suggests that the previous disturbance regime that facilitated oak replacement is no longer present.

\section{Conclusion}

Witness tree tallies from early land surveys are a valuable reference to the composition of the eastern forest at the time of early European settlement, and by inference, the disturbance regime of the period. Some bias in tree selection, particularly with regard to tree size, was probably present, but in terms of species composition of the overstory, this bias is of little concern. Based on witness tree data, the presettlement forests were primarily oak forests. White oak was dominant by a large margin; on average, black oak was the second most abundant species, and notably, much more important than northern red oak. Shade tolerant species, particularly red maple, were much less abundant than in current inventories. For the one area where size distribution data is available, the structure of this forest suggests a variable disturbance regime that allowed trees of all shade tolerances and growth strategies to occupy a portion of the canopy.

For the counties of this study, forest clearing was at least initially more closely tied to early settlement patterns and local economies. Although some intensive logging occurred in the study area in connection with the charcoal industry and the extension of the railroads, the processes of forest clearing, fire, and grazing were well underway by the time the most intensive logging operations of the late 1800s occurred elsewhere in the region. Thus human disturbances began earlier, lasted longer, and varied in intensity, but their impact on forest composition was 
no less significant, and continued into the early $20^{\text {th }}$ century when clearing of second growth forests, as well as invasive insects and disease further altered forest composition and structure. By the time of the most current forest inventories, significant shifts in species composition and dominance became evident. This change was marked by a significant increase in early successional species such as yellow-poplar, red maple, and black cherry that thrived in a high light environment where a combination of fire suppression, deer herbivory, and high levels of understory shade had reduced the potential for oak success. The following chapters will consider the small plot-scale dynamics of this change. 


\section{Literature cited}

Abrams, M. D. 1992. Fire and the development of oak forests. BioScience 42: 346-353.

Abrams, M. D. 1998. The red maple paradox. BioScience 48: 355-364.

Abrams, M. D. 2000. Fire and the ecological history of oak forests in the eastern United States. In Yaussey, D. A., comp. Proceedings: workshop on fire, people, and the central hardwoods landscape. USDA For. Ser. Gen. Tech. Rep. NE-247.

Abrams, M. D. and J. A. Downs. 1990. Successional replacement of old-growth white oak by mixed mesophytic hardwoods in southwestern Pennsylvania. Can. J. For. Res. 20: 1864-1870.

Abrams, M. D. and C. M. Ruffner. 1995. Physiographic analysis of witness-tree distribution (1765-1798) and present forest cover through north central Pennsylvania. Can. J. For. Res. 25: 659-668.

Abrams, M. D. and D. M. McCay. 1996. Vegetation-site relationships of witness trees (17801856) in the presettlement forests of eastern West Virginia. Can. J. For. Res. 26: 217-224.

Adovasio, J. M. and D. R. Pedlar. 2000. A long view of deep time at Meadowcroft Rockshelter. In Proceedings, Current Archaeological Research in Pennsylvania and Related Areas, $65^{\text {th }}$ Annual Meeting for the Society for American Archaeology, Philadelphia, Pennsylvania, April 59, 2000.

Beverley, R. 1971. The history and present state of Virginia: a selection. Bobbs-Merrill, Indianapolis, IN.

Bonnicksen, T. M. 2000. America's ancient forests: from the ice age to the age of discovery. John Wiley \& Sons, New York, NY.

Bourdo, E. A., Jr. 1956. A review of the General Land Office survey and of its use in quantitative studies of former forests. Ecology 37: 754-768.

Braun, E. L. 1950. Deciduous forests of eastern North America. Blakiston Co., Philadelphia, PA.

Ludwig, J. A., and J. F. Reynolds. 1988. Statistical Ecology. New York: John Wiley and Sons.

Bromley, S. W. 1935. The original forest types of southern New England. Ecological Monographs 5:61-89.

Brooks, A. B. 1910. Forestry and wood industries. Acme Pub. Co., Morgantown, WV.

Canham, C. D. and O. L. Loucks. 1984. Catastrophic windthrow in the presettlement forests of Wisconsin. Ecology 65: 804-809. 
Chapman, J, P. A. Delcourt, and P. A. Cridlebaugh. 1982. Man-land interactions: 10,000 years of American impact on native ecosystems in the Lower Little Tennessee River Valley, eastern Tennessee. Southeastern Archaeology 1: 115-121.

Core, E. L. 1974. The Monongalia story: a bicentennial history. McClain Publishing Company, Parsons, WV.

Crow, T. R. 1988. Reproductive mode and mechanisms for self-replacement of northern red oak (Quercus rubra): a review. For. Sci. 34: 19-40.

Davis, M. B. 1981. Quaternary history and the stability of forest communities. Chapter 10 In West, D. C., H. H. Shugart, and D. B. Botkin, eds. Forest succession. Springer-Verlag, New York, NY.

Davis, M. B. 1996. Extent and location. Chapter 2 In Davis, M. B., ed. Eastern old-growth forests: prospects for rediscovery and recovery. Island Press, Washington, D.C.

Day, G. M. 1953. The Indian as an ecological factor in the northeastern forest. Ecology 34: 329-346.

Delcourt, H. R. and P. A. Delcourt. 1974. Primeval magnolia-holly-beech climax in Louisiana. Ecology 55: 638-644.

Delcourt, P. A. and H. R. Delcourt. 1987. Long-term forest dynamics of the temperate zone. Springer-Verlag, New York, NY.

Delcourt, H. R. and P. A. Delcourt. 1996. Presettlement landscape heterogeneity: evaluating grain of resolution using General Land Office Survey data. Landscape Ecology 11: 363-381.

Delcourt, H. R. and P. A. Delcourt. 1998. Pre-Columbian native American use of fire on southern Appalachian landscapes. Conservation Biology 11: 1010-1014.

Eyre, F. H. (editor) 1980. Forest cover types of the United States and Canada. Society of American Foresters, Washington, DC.

Goff, F. G. and D. West. 1975. Canopy-understory interaction: effects on forest population structure. For. Sci. 21: 98-108.

Hamel, P. B. and E. R. Buckner. 1998. How far could a squirrel travel in the treetops? A prehistory of the southern forest. Trans. $63^{\text {rd }}$ No. Am. Wildl. And Natur. Resour. Conf. pp. 309315.

Henry, J. D. and J. M. A. Swan. 1974. Reconstructing forest history from live and dead plant material - an approach to the study of forest succession in southwest New Hamphire. Ecology 55: 772-783. 
Hughes, S. S. 1979. Surveyors and statesmen: land measuring in colonial Virginia. Virginia Association of Surveyors, Richmond, VA.

Iverson, L. R., A. M. Prasad, B. J. Hale, and E. K. Sutherland. 1999. An atlas of current and potential future distributions of common trees of the Eastern United States. USDA For. Ser. Gen. Tech. Rep. NE-265. <www.fs.fed.us/ne/delaware/atlas>

Jenning, O. E. 1927. Classification of the plant societies of central and western Pennsylvania. Proc. Pa. Acad. Sci. 1:23-55.

Keever, C. 1953. Present composition of some stands of the former oak-chestnut forest in the southern Blue Ridge Mountains. Ecology 34: 44-54.

Kent, M. and P. Coker. 1992. Vegetation description and analysis: a practical approach. John Wiley \& Sons, New York, NY.

Kline, V. M. and G. Cottam. 1979. Vegetation response to climate and fire in the Driftless Area of Wisconsin. Ecology 60: 261-268.

Kuchler, A. W. 1964. Potential natural vegetation of coterminous United States. American Geographic Society, Spec. Publ. 36.

Lederer, J., and W. Talbott. 1672. The discoveries of John Lederer in three several marches from Virginia, to the west of Carolina, and other parts of the continent begun in March, 1669 and ended in September, 1670. Samuel Heyrick, London, England.

Leitner, L. A. and M. T. Jackson. 1981. Presettlement forests of the unglaciated portion of southern Illinois. Amer. Mid. Nat. 105: 290-304.

Lewis, R. L. 1998. Transforming the Appalachian countryside: railroads, deforestation, and social change in West Virginia, 1880-1929. Univ. North Carolina Press, Chapel Hill, NC.

Loeb, R. E. 1987. Pre-European settlement forest composition in east New Jersey and southeastern New York. Am. Mid. Nat. 118:414-423.

Lorimer, C. G. 1977. The presettlement forest and natural disturbance cycle of northeastern Maine. Ecology 58:139-148.

Lorimer, C. G. 1984. Development of the red maple understory in Northeastern oak forests. Forest Sci. 30: 3-22.

Lorimer, C. G. 1993. Causes of the oak regeneration problem. Pp. 14-39 In Loftis, D. L. and C. E. McGee, eds. Oak regeneration: serious problems, practical recommendations. USDA For. Ser. Res. Pap. NE-356. 
Lorimer, C. G., J. W. Chapman, and W. D. Lambert. 1994. Tall understory vegetation as a factor in the poor development of oak seedlings beneath mature stands. J. Ecology 82: 227-237.

Lutz, H. J. 1930a. The vegetation of Heart's Content, a virgin forest in northwestern Pennsylvania. Ecology 11: 1-29.

Lutz, H. J. 1930b. Original forest composition in northwestern Pennsylvania as indicated by early land survey notes. J. of For. 28: 1098-1103.

MacCleery, D. W. 1992. American forests: a history of resiliency and recovery. USDA For. Ser. FS-540.

Martin, J. A. 1835. A new and comprehensive gazetter of Virginia and the District of Columbia. J. Martin, Charlottesville, VA.

Maxwell, H. (chairman). 1908. Report of the West Virginia Conservation Commission. Tribune Printing Co., Charleston, WV.

Maxwell, H. 1910. The use and abuse of forests by the Virginia Indians. William and Mary College Quarterly Historical Magazine. 19: 73-103.

McCune, B. and M. J. Mefford. 1997. PC-ORD. Multivariate analysis of ecological data, version 3.0. MjM Software Design, Glenedon Beach, OR.

McIntosh, R. P. 1962. The forest cover of the Catskill Mountain region, New York, as indicated by land survey records. Am. Mid. Nat. 68: 409-423.

McKelvey, A. T., ed. 1903. Centennial history of Belmont County Ohio and representative citizens. Biographical Publishing Company, Chicago, Ill.

Michaux, F. A. 1853. North American Silvan. Vol 1. Robert P. Smith Publishing Company, Philadelphia, PA.

Moreland, J. R. 1940. The early Cheat Mountain iron works. Monongalia Historical Society, Morgantown, WV.

Nowacki, G. J., M. D. Abrams, and C. G. Lorimer. 1990. Composition, structure, and historical development of northern red oak stands along an edaphic gradient in north-central Wisconsin. For. Sci. 36: 276-292.

Nowacki, G. J. and M. D. Abrams. 1992. Community, edaphic, and historical analysis of mixed oak forests of the Ridge and Valley Province in central Pennsylvania. Can. J. For. Res. 22: 790800 .

Nowacki, G. J. and P. A. Trianosky. 1994. Literature on old-growth forests of eastern North America. Natural Areas Journal 13: 87-107. 
Orwig, D. A. and M. D. Abrams. 1994. Land-use history (1720-1992), composition, and dynamics of oak-pine forests within the Piedmont and Coastal Plain of northern Virginia. Can. J. For. Res. 24: 1216-1225.

Palmer, M. W. 1990. The estimation of species richness by extrapolation. Ecology 71: 11951198.

Pearse, J. B. 1876. A concise history of the iron manufacture of the American colonies up to the revolution, and of Pennsylvania until the present time. Allen, Lane \& Scott, Philadelphia, PA.

Peattie, D. C. 1950. A natural history of trees of eastern and central North America. Houghton Mifflin, Boston, MA.

Pyne, S. J., P. L. Andrews, and R. D. Laven. 1996. Introduction to wildland fire. $2^{\text {nd }}$ ed. John Wiley \& Sons, New York, NY.

Rice, O. K. 1970. The Allegheny frontier: West Virginia beginnings, 1730-1830. University of Kentucky Press, Lexington, KY.

Ruffner, C. M. and M. D. Abrams. 1998. Relating land-use history and climate to the dendroecology of a 326-year old Quercus prinus talus slope forest. Can. J. For. Res. 28: 347358.

Russell, E. W. 1980. Vegetational change in northern New Jersey from precolonization to the present: a palynological interpretation. Bull. Torry Bot. Club 107: 432-446.

Sears, P. B. 1925. The natural vegetation of Ohio. Ohio J. Science 25: 139-149.

Schnur, G. L. 1937. Yield, stand, and volume tables for even-aged upland oak forests. Technical Bullletin 560, USDA For. Ser. 88 pp.

Schuler, T. M. 1998. Patterns of oak regeneration in a central Appalachian forest. Ph.D. dissertation. Purdue University, West Lafayette, IN.

Siccama, T. G. 1971. Presettlement and present forest vegetation in northern Vermont with special reference to Chittenden County. Am. Mid. Nat. 85: 153-172.

Simpson, C. 1860. Great Kanawha Estate, evidence of value and title.

Sipe, F. H. 1965. Surveying rural property boundary lines in West Virginia: a guide for surveyors, attorneys, landowners and others. McClain Printing Co., Parsons, WV.

Spurr, S. H. 1951. George Washington, surveyor and ecological observer. Ecology 32: 544549. 
Sprugel, D. G. 1991. Disturbance, equilibrium, and environmental variability: what is 'natural' vegetation in a changing environment? Biol. Cons. 58: 1-18.

Stephenson, S. L. 1986. Changes in a former chestnut-dominated forest after a half century of succession. Amer. Mid. Nat. 116: 173-179.

Stephenson, S. L., A. N. Ash, and D. F. Stauffer. 1993. Appalachian oak forests. Chapter 6 In Martin, W. H., S. G. Boyce, and A. C. Echternacht, eds. Biodiversity of the southeastern United States: upland terrestrial communities. John Wiley \& Sons, New York, NY.

Stout, W. 1933. The charcoal iron industry of the Hanging Rock iron district: its influence on the early development of the Ohio Valley. Ohio State Archaeological and Historical Quarterly 42: $72-104$.

Sutherland, E. K. 1997. History of fire in a southern Ohio second-growth mixed oak forest. In. Pallardy, S. G., R. A. Cecich, H. G. Garrett, and P. S. Johnson, eds. Proc. $11^{\text {th }}$ central hardwood forest conference. USDA For. Ser. Gen Tech. Rep. NC-188.

USDA 2001. Forest Inventory and analysis data base and retrieval system. USDA Forest Service. http://wWw.srsfia.usfs.msstate.edu

Wade, D. D., B. L. Brock, P. H. Brose, J. B. Grace, G. A. Hock, and W. A. Patterson III. 2000. Fire in eastern ecosystems. Chapter 4 In Brown, J. K. and J. K. Smith, eds. Wildland fire in ecosystems: effects of fire on flora. USDA For. Ser. Gen. Tech. Rep. RMRS-42 Vol. 2

Watts, W. A. 1979. Late Quaternary vegetation of central Appalachia and the New Jersey coastal plain. Ecological Monographs 49: 427-469.

Webb, T., III. 1988. Glacial and holocene vegetation history: eastern North America. Pp. $385-$ 414 In Huntley, B. and Webb, T., eds. Vegetation history. Kluwer Academic Publishers, Dordrecht, The Netherlands.

White, C. A. 1983. A history of the rectangular survey system. U.S. Government Printing Office, Washington, DC.

Yarnell, R. A. 1976. Early plant husbandry in eastern North America. In Cleland, C. E., ed. Cultural change and continuity. Academic Press, Orlando, FL.

Yarnell, S. L. 1998. The southern Appalachians: a history of the landscape. USDA For. Ser. Gen. Tech. Rep. SRS-18. 
Table 2.1. More common components of species-groups used in eastern FIA surveys.

\begin{tabular}{|c|c|c|c|}
\hline Species-group & Species & Species-group & Species \\
\hline Select white oak & $\begin{array}{l}\text { bur oak } \\
\text { chinkapin oak } \\
\text { swamp white oak } \\
\text { white oak }\end{array}$ & Other white oak & $\begin{array}{l}\text { chestnut oak } \\
\text { post oak }\end{array}$ \\
\hline Select red oak & northern red oak & Other red oak & $\begin{array}{l}\text { black oak } \\
\text { blackjack oak } \\
\text { pin oak } \\
\text { scarlet oak } \\
\text { shingle oak } \\
\text { southern red oak }\end{array}$ \\
\hline Hard maple & $\begin{array}{l}\text { black maple } \\
\text { sugar maple }\end{array}$ & Soft maple & $\begin{array}{l}\text { red maple } \\
\text { silver maple }\end{array}$ \\
\hline Other soft hardwoods & $\begin{array}{l}\text { black cherry } \\
\text { boxelder } \\
\text { buckeye } \\
\text { butternut } \\
\text { cucumber tree } \\
\text { elm } \\
\text { hackberry } \\
\text { sassafras } \\
\text { sycamore }\end{array}$ & Other hard hardwoods & $\begin{array}{l}\text { American chestnut } \\
\text { American holly } \\
\text { black birch } \\
\text { black locust } \\
\text { flowering dogwood } \\
\text { honey locust }\end{array}$ \\
\hline $\begin{array}{l}\text { Noncommercial } \\
\text { species }\end{array}$ & $\begin{array}{l}\text { tree of heaven } \\
\text { Eastern hophornbeam } \\
\text { hawthorne } \\
\text { musclewood } \\
\text { pawpaw } \\
\text { pin cherry } \\
\text { red bud } \\
\text { serviceberry } \\
\text { sourwood } \\
\text { striped maple }\end{array}$ & & \\
\hline
\end{tabular}


Table 2.2. Abundance of tree species cited as witness trees in early land surveys and deeds for five counties in Ohio, Pennsylvania, and West Virginia

Importance value (IV)

\begin{tabular}{|c|c|c|c|c|c|c|}
\hline Name cited & Scientific name ${ }^{1}$ & $\begin{array}{c}\text { Belmont } \\
\mathrm{OH}\end{array}$ & $\begin{array}{c}\text { Washington } \\
\text { PA }\end{array}$ & $\begin{array}{c}\text { Harrison } \\
\text { WV }\end{array}$ & $\begin{array}{c}\text { Ritchie } \\
\text { WV }\end{array}$ & $\begin{array}{l}\text { Lewis } \\
\text { WV }\end{array}$ \\
\hline boxelder & Acer negundo & & & & & 0.3 \\
\hline maple & Acer rubrum & 1.5 & 2.2 & 3.1 & 4.7 & 3.7 \\
\hline sugar tree & Acer saccharum & 8.7 & 3.6 & 10.6 & 5.5 & 3.7 \\
\hline buckeye & Aesculus octandra & 1.9 & 0.5 & 0.5 & 0.7 & 1.1 \\
\hline serviceberry, sarvis & Ameliancher arborea & & 0.6 & 0.2 & 1.7 & \\
\hline birch, burch & Betula lenta, nigra & 2.5 & & 1.1 & & 0.3 \\
\hline iron wood & Carpinus caroliniana & & 1.2 & & 1.2 & \\
\hline hickory & Carya spp. & 8.9 & 11.4 & 9.0 & 9.2 & 8.4 \\
\hline chestnut & Castanea dentata & 3.4 & 0.5 & 2.4 & 1.7 & 1.5 \\
\hline red bud & Cercis canadensis & 0.4 & & & & \\
\hline hoop ash & Celtis occidentalis & 0.2 & & & & \\
\hline dogwood & Cornus florida & 1.1 & 4.0 & 0.8 & 9.0 & 4.7 \\
\hline thorn tree & Crataegus spp. & & 0.7 & & & \\
\hline beach, beech & Fagus grandifolia & 5.5 & 1.1 & 8.3 & 5.5 & 14.8 \\
\hline ash & Fraxinus americana & 1.1 & 2.1 & 1.1 & 0.7 & 2.3 \\
\hline white walnut & Juglans cinera & 1.5 & 0.5 & 0.7 & & 0.9 \\
\hline walnut, black walnut & Juglans nigra & 2.5 & 1.7 & 3.1 & 1.4 & 0.4 \\
\hline poplar, white wood, & Lirodendron tulipifera & 2.8 & 3.6 & 4.1 & 9.7 & 7.5 \\
\hline cucumber tree & Magnolia acuminata & & & 0.2 & & \\
\hline crab apple & Malus spp. & & 0.1 & & & \\
\hline mulberry & Morus rubra & & & & & 0.4 \\
\hline gum & Nyssa sylvatica & 0.8 & 2.9 & 5.9 & 7.8 & 4.7 \\
\hline hophornbeam & Ostrya virginia & 0.4 & & & & 0.3 \\
\hline sourwood & Oxydendron arboreum & & & & 1.4 & \\
\hline pine, jackpine & Pinus rigida, virginiana & 1.5 & 0.5 & 0.8 & 0.7 & 0.3 \\
\hline white pine & Pinus strobus & & 0.2 & & & \\
\hline sycamore, plane tree & Platanus occidentalis & & 0.8 & & & 1.2 \\
\hline cherry & Prunus serotina & 0.2 & 0.8 & & 0.3 & 0.3 \\
\hline white oak & Quercus alba & 38.8 & 39.1 & 32.4 & 23.9 & 28.8 \\
\hline spanish oak $^{2}$ & Quercus coccinea & 0.4 & 2.1 & & 0.2 & 0.9 \\
\hline blackjack oak & Quercus marylandica & & & & 0.2 & \\
\hline chestnut oak, rock oak & Quercus prinus & & 1.2 & 0.5 & 1.2 & 2.5 \\
\hline red oak & Quercus rubra & 1.1 & 2.9 & 0.5 & 2.2 & 2.5 \\
\hline black oak, yellow oak & Quercus velutina & 10.4 & 13.0 & 12.7 & 10.0 & 6.0 \\
\hline locust & Robinia pseudoacacaia & & 0.5 & 0.8 & 0.2 & 1.1 \\
\hline sassafras & Sassafras albidum & & 0.2 & & & \\
\hline lynn, lyme, linden & Tilia americana & & 1.1 & 0.7 & 0.9 & 1.2 \\
\hline elm & Ulmus american, rubra & 4.4 & 1.1 & 0.7 & & 0.5 \\
\hline \multicolumn{2}{|c|}{ Number of witness trees talied } & 472 & 1323 & 614 & 578 & 751 \\
\hline \multicolumn{2}{|c|}{ Species richness } & 23 & 29 & 23 & 25 & 27 \\
\hline
\end{tabular}

${ }^{1}$ some based on Peattie (1950)

${ }^{2}$ also know as pin oak (Q. palustris, Loeb 1987) and southern red oak (Q. falcata, Peattie 1950) 
Table 2.3. Comparison of species-group importance value (IV) and change in rank (dRk) for presettlement and USDA Forest Service FIA data. Presettlement data are from witness-tree records. FIA data are for trees $>12.7 \mathrm{~cm} \mathrm{dbh}$. A positive value for dRk indicates that an increase in relative ranking from presettlement to present.

\begin{tabular}{|c|c|c|c|c|c|c|c|c|c|c|c|c|c|c|c|}
\hline \multirow{2}{*}{ Species-group $^{1}$} & \multicolumn{3}{|c|}{ Belmont Co. OH } & \multicolumn{3}{|c|}{ Washington Co., PA } & \multicolumn{3}{|c|}{ Harrison Co., WV } & \multicolumn{3}{|c|}{ Ritchie Co., WV } & \multicolumn{3}{|c|}{ Lewis Co., WV } \\
\hline & IV-Pres & IV-FIA & $\mathrm{dRk}$ & IV-Pres & IV-FIA & $\mathrm{dRk}$ & IV-Pres & IV-FIA & $\mathrm{dRk}$ & IV-Pres & IV-FIA & dRk & IV-Pres & IV-FIA & $\mathrm{dRk}$ \\
\hline pine & 1.5 & 2.8 & -2 & 0.6 & 2.7 & +7 & 0.8 & 0.7 & -4 & 0.7 & 9.6 & +11 & 0.3 & 0.6 & -1 \\
\hline eastern hemlock & -- & -- & -- & -- & -- & -- & -- & -- & -- & -- & 1.1 & -- & -- & -- & -- \\
\hline select white oak & 38.8 & 6.7 & -3 & 39.1 & 1.8 & -10 & 32.4 & 6.0 & -6 & 23.9 & 16.6 & 0 & 28.8 & 5.2 & -5 \\
\hline select red oak & 1.1 & 4.2 & +4 & 2.9 & 2.6 & -2 & 0.5 & 2.5 & +2 & 2.2 & 3.6 & +1 & 2.5 & 2.5 & 0 \\
\hline other white oak & -- & 0.3 & -- & 1.2 & 0.3 & -4 & 0.5 & 2.8 & +4 & 1.2 & 6.8 & +5 & 2.5 & 4.4 & +4 \\
\hline other red oak & 10.8 & 1.2 & -14 & 15.1 & 1.5 & -11 & 12.7 & 3.2 & -6 & 10.4 & 6.9 & -4 & 6.9 & 6.3 & +1 \\
\hline hickory & 8.9 & 3.3 & -6 & 11.4 & 5.1 & -5 & 9.0 & 14.3 & +2 & 9.2 & 10.4 & +2 & 8.4 & 14.0 & 0 \\
\hline sugar/black maple & 8.7 & 10.1 & +1 & 3.6 & 9.3 & +4 & 10.6 & 8.7 & -2 & 5.5 & 3.2 & -4 & 3.7 & 4.9 & +3 \\
\hline $\mathrm{red} / \mathrm{silver}$ maple & 1.5 & 18.3 & +8 & 2.2 & 6.3 & +6 & 3.1 & 11.6 & +6 & 4.7 & 13.2 & +7 & 3.7 & 16.3 & +8 \\
\hline American beech & 5.5 & 2.8 & -4 & 1.1 & 0.9 & -1 & 8.3 & 3.1 & -5 & 5.5 & 4.9 & -1 & 14.8 & 2.5 & -10 \\
\hline sweetgum & -- & -- & -- & -- & -- & -- & -- & -- & -- & -- & -- & -- & -- & 0.1 & -- \\
\hline black gum & 0.8 & 0.2 & -5 & 2.9 & 0.7 & -7 & 5.9 & 1.2 & -9 & 7.8 & 1.7 & -7 & 4.7 & 1.8 & -7 \\
\hline ash & 1.1 & 6.4 & +7 & 2.1 & 6.8 & +8 & 1.1 & 6.8 & +6 & 0.7 & 1.9 & +5 & 2.3 & 3.7 & +3 \\
\hline cottonwood/aspen & -- & 2.6 & -- & -- & 1.4 & -- & -- & 0.4 & -- & -- & 0.7 & -- & -- & 1.6 & -- \\
\hline basswood & -- & 1.4 & -- & 1.1 & 0.0 & -4 & 0.7 & 0.8 & -4 & 0.9 & 0.6 & -4 & 1.2 & 0.4 & -6 \\
\hline yellow-poplar & 2.8 & 5.4 & +1 & 3.6 & 5.2 & +1 & 4.1 & 10.9 & +4 & 9.7 & 8.7 & 0 & 7.5 & 16.9 & +4 \\
\hline black walnut & 2.5 & 1.5 & -5 & 1.7 & 5.1 & +6 & 3.1 & 2.2 & -2 & 1.4 & 1.0 & -5 & 0.4 & 1.0 & -1 \\
\hline other soft hardwood & 8.3 & 23.6 & +4 & 3.9 & 36.9 & +4 & 2.0 & 19.8 & +10 & 1.0 & 7.2 & +8 & 4.3 & 11.6 & +4 \\
\hline other hard hardwood & 7.0 & 5.9 & 0 & 5.1 & 4.1 & +3 & 5.2 & 3.5 & -1 & 10.9 & 0.2 & -18 & 7.5 & 3.9 & -4 \\
\hline noncommercial & 0.8 & 2.9 & +4 & 2.6 & 8.4 & +7 & 0.2 & 1.6 & +2 & 4.3 & 1.7 & -4 & 0.7 & 2.3 & +2 \\
\hline Years surveyed & 1786 & 1991 & & 1784 & 1990 & & 1784 & 1989 & & 1784 & 1989 & & $1817-19$ & 1989 & \\
\hline Number surveys/plots & 74 & 41 & & 103 & 86 & & 130 & 67 & & 125 & 67 & & 106 & 40 & \\
\hline Number trees & 473 & 1086 & & 1323 & 2604 & & 614 & 1989 & & 578 & 1313 & & 751 & 1058 & \\
\hline
\end{tabular}


Figure 2.1. Location map of five oak-dominated old-growth study sites and USDA Forest Service Forest Inventory Analysis (FIA) county inventories.

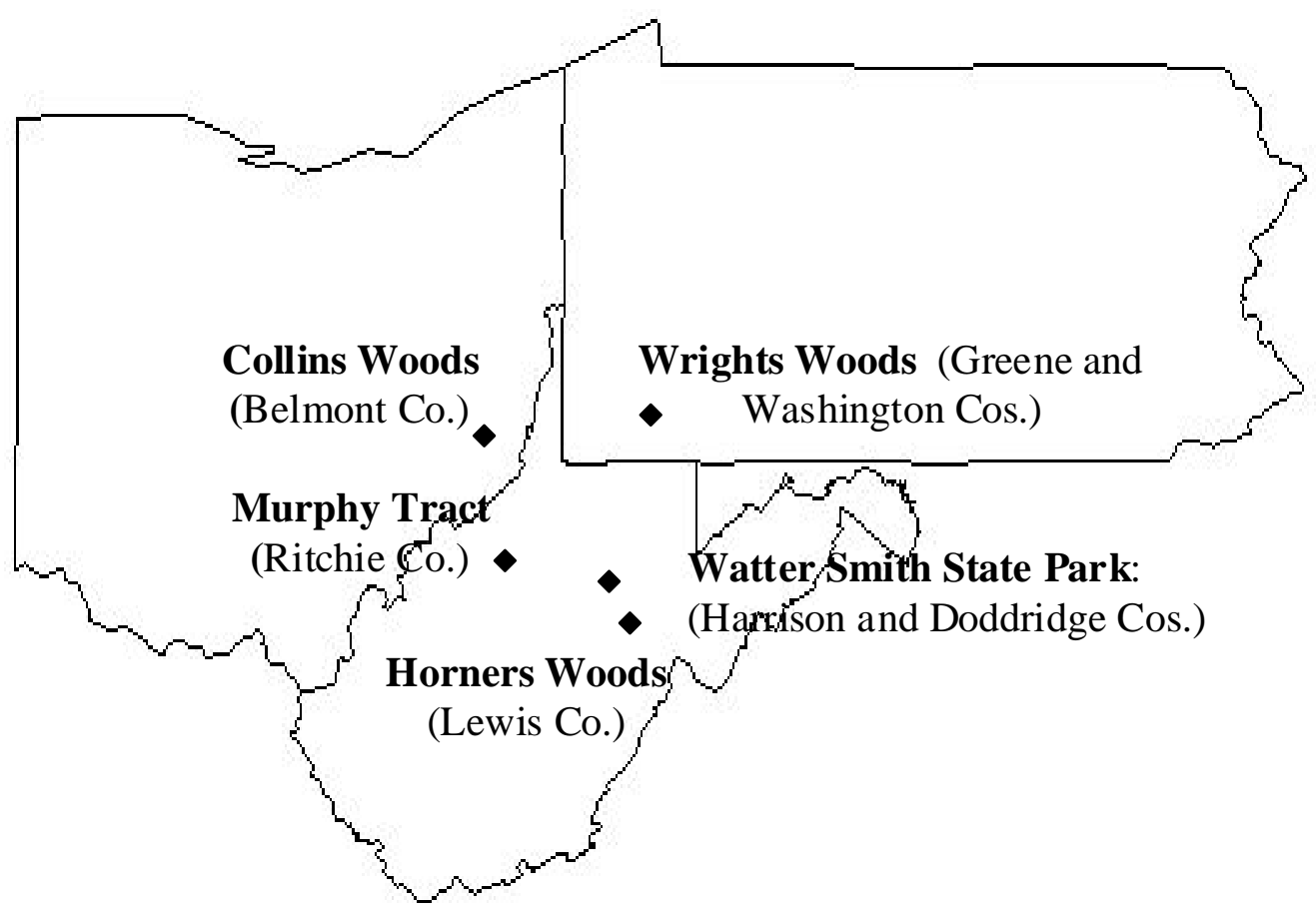


Figure 2.2. Diameter distribution of witness trees from township surveys, Kirkwood Township, Belmont County, Ohio, 1786-1804.

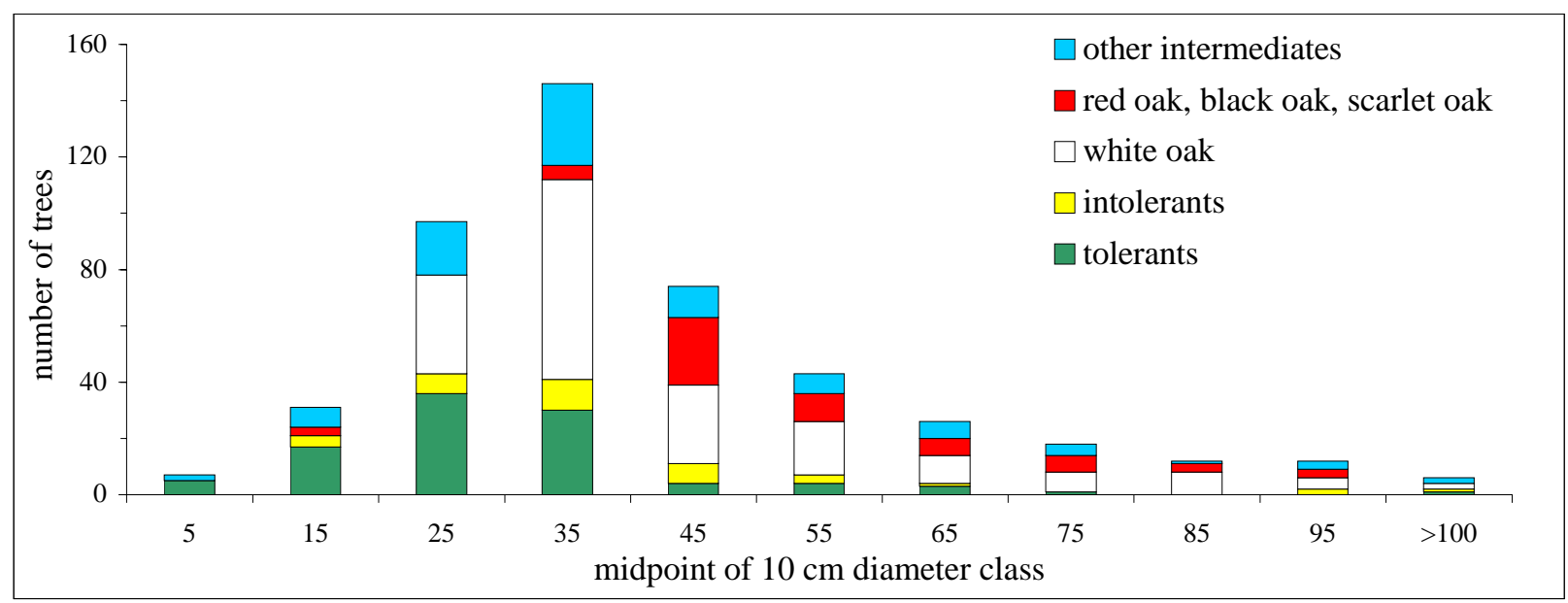

Species code:

tolerants: dogwood, American beech, black gum, buckeye, sugar maple, red maple intolerants: yellow-poplar, black cherry, butternut, black walnut

intermediates: hackberry, hickories, American chestnut, white ash, pines, elms 
Figure 2.3. Cluster analysis of presettlement-era (PresS) forest composition based on witness tree tallies and modern USDA Forest Service Forest Inventory Analysis (FIA) data. Data are input as importance values; species follow FIA groupings. Distance measure is Euclidean distance, and clusters are linked using Ward's method.

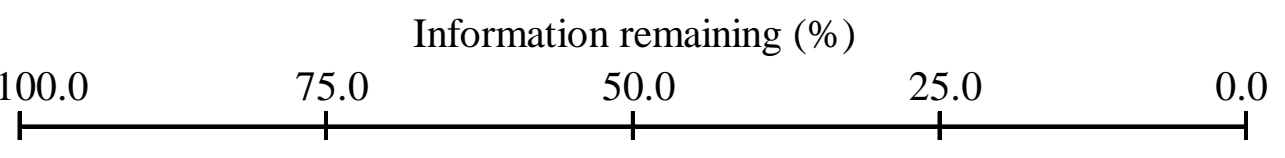

Belmont Co. FIA

Wash. Co. FIA

Ritchie Co. FIA

Lewis Co. FIA

Harrison Co. FIA

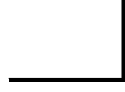

Belmont Co. PreS

Wash. Co. PreS

Harrison Co. PreS

Ritchie Co. PreS

Lewis Co. PreS

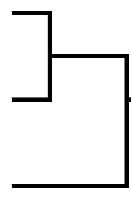

Percent chaining $=6 \%$ 
Figure 2.4. Comparison of a) importance values and b) diameter distribution (Belmont County, Ohio, only) using witness tree tallies and FIA data. Data grouped by tolerance of shade and competition. For FIA data, only trees $>12.5 \mathrm{~cm} \mathrm{dbh}$ used.
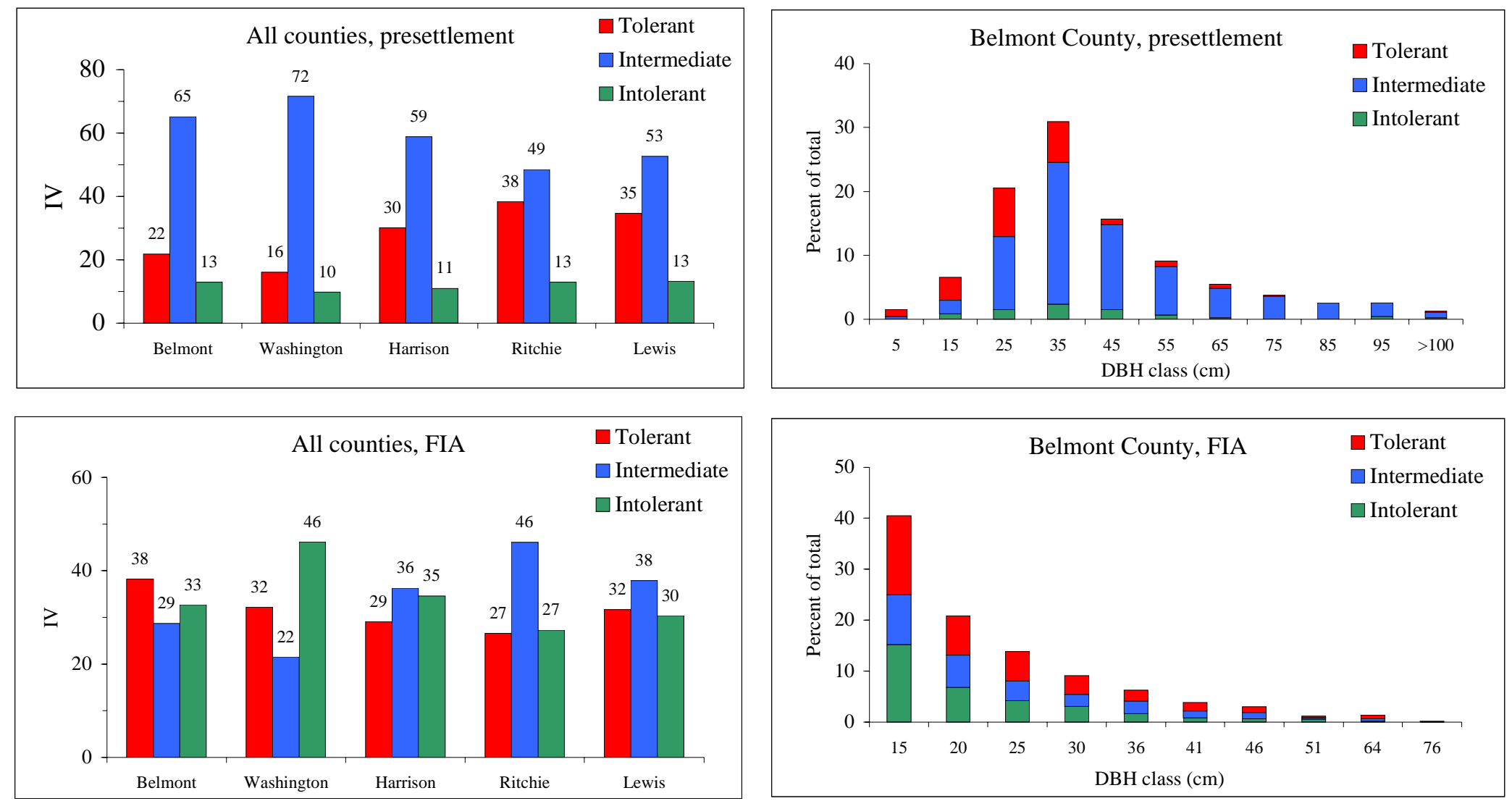

Tolerance ranking:

Tolerant : red maple, sugar maple, buckeye, serviceberry, hophornbeam, musclewood, red bud, dogwood, American beech, black gum, sassafras, basswood Intermediate: hickories, American chestnut, hackberry, cucumber tree, white pine, sycamore, white oak, red oak, black oak, chestnut oak, American elm, red elm Intolerant : black birch, hawthornes, white ash, butternut, black walnut, yellow-poplar, Virginia pine, black cherry, scarlet oak, black locust 


\title{
CHAPTER 3
}

\section{ClimATE, CANOPY DISTURBANCE, AND RADIAL GROWTH AVERAGING}

\section{IN A SECOND GROWTH MIXED-OAK FOREST IN WEST VIRGINIA UNIVERSITY FOREST}

\begin{abstract}
Radial growth averaging has been proposed as a technique of determining the frequency and intensity of disturbances affecting older, canopy oak trees. This method combines an analysis of age-structure with decadal averaging of tree-ring width to identify canopy disturbance events and characterize disturbance regimes over long time periods. This study used a thinning experiment in a 55 year-old second-growth mixed-oak stand in West Virginia, in which the amount of crown release of residual chestnut oak (Quercus prinus) and northern red oak $(Q$. rubra) trees was recorded, to test the radial growth averaging method. From the dendroclimatological analysis, current June precipitation and temperature, previous August temperature, and previous September precipitation yielded the highest correlations with annual radial growth. However, the number and magnitude of climatic correlations were relatively small, and the proportion of tree-ring variation accounted for by climate was higher for unreleased, control trees than for trees in the thinned groups. Analysis of variance was used to determine the time interval and lag period that best captured the growth associated with different levels of crown release. A lag of 3 years and an averaging interval of 7 years yielded the best statistical fit of percent growth change and percent crown release for chestnut oak; for red oak, the radial growth response did not differ significantly when lag and interval were varied from 1 to 3 , and 6 to 15 years, respectively. The relationship between percent crown release and percent
\end{abstract}


growth change was linear for both species. Coefficients of the linear model were 0.95 and 1.10 for chestnut oak and red oak respectively; thus a $25 \%$ crown release yielded, on average, a $25 \%$ growth change. This method provides a suitable means of detecting canopy disturbances and estimating the intensity of canopy disturbance affecting overstory trees. It is potentially applicable to a range of tree species, although its use on non-oak species will depend on quantification of the relationship between percent growth change and percent crown release. For eastern, oak-dominated forests, radial growth averaging provides a means of quantifying the historic rate of canopy disturbances both in specific stands, and on a regional basis. When combined with fire histories, these data can provide the basis for reconstructing long-term disturbance regimes. Such information is valuable in areas where difficulties regenerating oaks has stimulated research into the historic conditions under which such stands originated. This estimate may provide a framework for scheduling the rate of stand entry for silvicultural treatments (e.g., thinning) that is consistent with its historic stand development. 


\section{Introduction}

Natural disturbances in forests kill vegetation and release growing space (Oliver and Larson 1996). They are simultaneously a source of mortality for some individuals and a source of establishment and growth for others, and the ongoing process of death and replacement has a profound effect on forest structure and composition. In fact, many features of forests are better understood as responses to different kinds of disturbances rather than the result of a continuous change toward equilibrium (Brubaker 1987). The disturbance regime of a forest represents the sum total of stem and stand replacing events and many studies have characterized individual stands and forest types by disturbance agents, severity, and return time (Barden 1980; Romme and Martin 1982; Runkle 1982, 1985). In mesic, eastern deciduous forests, treefall gaps are the dominant disturbance type (Runkle 1982), especially as forests mature. These events create resource heterogeneity along light, temperature, humidity, and soil-resource gradients. In closed canopy, deciduous forests in the east, the amount, timing, and quality of available light may vary as functions of gap size, the depth of shade imposed by the height of the surrounding canopy, solar angle, latitude, and aspect (Canham et al. 1990). Because light levels beneath intact canopies average 1-6\% of full sunlight (Canham et al. 1990; Canham and Burbank 1994), increases in light levels in gaps are perhaps most influential in determining the growth of the survivors. Silvicultural treatments such as crown thinning, crop tree release, and shelterwood system recognize the importance of managing the light environment to favor growth of selected trees, and are comparable to changes in light availability resulting from natural mortality.

Studies of disturbance regimes of eastern deciduous forests have traditionally taken two approaches. Barden (1980, 1981), Runkle (1981, 1982, 1998), Cho and Boerner (1991) and 
others have identified gap makers and gap fillers, and have measured the frequency of gap formation, gap size, and gap closure rate by sampling along transects. These gap-sampling studies have described the disturbance regimes of relatively large sample areas. However, because it is difficult to interpret gaps older than 15 years (Cho and Boerner 1991), the sampling period of this method is limited to relatively short time intervals. A second approach concentrates on the response of the survivors. It combines analysis of the age structure of forests and their tree-ring record to estimate historic disturbance rates over much longer time periods (Lorimer 1984; Lorimer and Frelich 1989). Dendrochronological studies have been particularly effective in determining long-term forest dynamics (Foster 1988), fire histories (Buell et al. 1954; Sutherland 1997), insect outbreaks (Fajvan and Seymour 1993), and changes in species composition over many decades (Henry and Swan 1974, Abrams et al. 1997).

Radial growth analysis is particularly applicable in closed-canopy, eastern deciduous forests. Except on the most drought-prone sites, these forests are characterized by a relatively high degree of climatic complacency, i.e., radial growth patterns show relatively low variability, indicating that tree growth is relatively less affected by variations in climate (Fritts 1976) than by the effects of canopy disturbance and competition for growing space (Phipps 1982; Nowacki and Abrams 1997).

Lorimer and Frelich (1989) proposed a radial-growth averaging technique to identify canopy accession events of shade-tolerant understory trees such as sugar maple (Acer saccharum Marsh.) and beech (Fagus grandifolia Ehrh.). They distinguished between the magnitude of growth increases and their duration. Thus, major releases were characterized by average growth increases $\geq 100 \%$, while moderate releases involved increases between 50 and $99 \%$. Sustained releases last at least 15 years, while temporary releases last 10-15 years. These criteria were 
designed to identify canopy accession events of understory saplings and seedlings in canopy gaps, and to screen out cases of sidelight-responses (Lorimer and Frelich 1989).

Nowacki and Abrams (1997) modified this method for eastern, old-growth, overstory oaks (Quercus spp.). They noted that mature overstory oaks responded more conservatively to increased sidelight from canopy gaps than did smaller understory individuals to overhead gaps, and that the release criteria (50\%-100\% growth increase) proposed by Lorimer and Frelich (1989) were not sensitive enough to identify partial crown release events of less shade-tolerant overstory oaks that do not involve an advancement in canopy stratum. They proposed criteria based on a comparison of running 10-year ring-width averages to determine canopy disturbance rates, using the formula:

$$
\% \mathrm{GC}=\left[\left(\mathrm{M}_{2}-\mathrm{M}_{1}\right) / \mathrm{M}_{1}\right] * 100 \%
$$

where $\% \mathrm{GC}=$ percentage growth change, $\mathrm{M}_{1}=$ preceding 10-year mean radial growth (inclusive of the disturbance year), and $\mathrm{M}_{2}=$ subsequent 10-year mean (exclusive of the disturbance year) (Nowacki and Abrams 1997).

Three parameters are implicit in equation 1: 1) the length of the time period averaged, 2) the lag time between the disturbance and onset of growth increase, and 3) the selection of a minimum \%GC level that is both low enough to identify smaller canopy disturbance events (i.e., a single-tree mortality event that releases $25 \%$ of a neighboring tree's crown), and high enough to filter out drought-induced growth reduction and subsequent recovery (Nowacki and Abrams 1997). Drought effects in eastern mesic forests have been shown to last for only a 2 to 3 years (Cook and Jacoby 1977; Jacobi and Tainter 1988; Orwig and Abrams 1997), and sustained growth declines (approx. five years) associated with drought are observed for only the most severe drought events (Rubino and McCarthy 2000). Thus use of shorter averaging intervals (3 
to 5 years) risks confounding disturbance response with those that occur during drought recovery.

The 1-year lag and 10-year interval were proposed by Nowacki and Abrams (1997) because they are generally consistent with the onset and average duration of growth increases of overstory oaks that are associated with canopy disturbance events (Minckler 1967; Hilt 1979; Cutter et al. 1991). Standard stocking tables for upland oaks are based on a ten-year interval for an understocked (C level) stand to reach the lower level of full stocking (B level), when growing space is fully utilized (Gingrich 1967). However, Gingrich (1967) noted that the time interval between C- and B-level stocking may vary from as long as 12 to 15 years on poor sites (Site Index, SI, < $17 \mathrm{~m}$, upland oaks), to 5 to 8 years on very good sites (S.I. > $23 \mathrm{~m}$ ). In addition, Cutter et al. (1991) found a significant differential thinning response of 12 years for scarlet oak and a lag of 6 to 7 years. White oak released on 1-2 sides of their crown grew faster than unreleased trees for 20 years after treatment (Schlesinger 1978). In Arkansas, 50 year-old red oak crop trees responded the first year after release, however the greatest response occurred 5 to 10 years after release (Graney 1987). This chapter examines percent growth change over intervals between 6 and 15 years based on this range of values, and a natural gap disturbance regime that most often produces small $\left(<100 \mathrm{~m}^{2}\right.$; Barden 1981; Runkle 1985) and relatively short-lived canopy gaps (10-15 years; Runkle 1982; Cho and Boerner 1991).

Using data from several eastern oak thinning studies (Hilt 1979; Dale and Sonderman 1984; and Lamson et al. 1990), Nowacki and Abrams (1997) further proposed that a release of $35-40 \%$ of an individual's crown would yield a $25 \%$ GC. When this criteria was tested in three old-growth oak stands in central Pennsylvania, they found that the technique identified 31 of 43 known disturbance events dating as far back as 1684 . 
In eastern, closed-canopy deciduous forests, many factors act in concert to affect tree growth. Cook (1987) proposed a conceptual model that partitioned tree-ring variance among age- and size-related trends, climatic trends, endogenous disturbances (e.g., small canopy gaps), exogenous disturbances (e.g., larger, stand-wide events), and other random or unexplained variance. This study examines the relative contributions of climate and canopy disturbances to radial growth of canopy oaks, and tests the 10-year radial-growth averaging technique proposed by Nowacki and Abrams (1997) using data from a 1982 thinning study in West Virginia (Lamson et al. 1990). Its objectives were 1) to use standard dendroclimatological techniques (Cook and Kairiukstis 1990) to estimate the relative contributions of climatic and non-climatic variation to radial growth, 2) to examine the relationship between the percentage of tree crown perimeter released and radial growth of overstory, codominant northern red oak (Quercus rubra L.) and chestnut oak ( $Q$. prinus L.) using the radial-growth averaging technique, 3 ) in view of the variability of response times for different species, I was also interested in determining the response lag-time, and response-interval that best captured the radial growth change associated with crown release, and 4) to evaluate the radial growth averaging technique as a method of reconstructing canopy disturbance history.

Description of study area and methods

Study area and pretreatment stand condition. The study area consists of a 24.3 ha stand located on the 3100 ha West Virginia University Forest, $13 \mathrm{~km}$ east of Morgantown, WV (39 $39^{\prime} 43^{\prime \prime}$ N, 79 $45^{\prime} 28^{\prime \prime} \mathrm{W}$; Lake Lynn 7.5 minute Quadrangle). Bedrock for the area is part of the Upper Connequenescing sandstones of the Pottsville series, which include conglomeratic 
sandstones, thin coals, fire clay, and shale. Pottsville sandstones form the protective mantle at the top of Chestnut Ridge, and are highly resistant to erosion. Soils are characterized as Dekalb series on well-drained hill slopes and ridgetops, and deeper Ernest series on concave slopes bordering streams (USDA 1959). These are loamy-skeletal, moderately deep and well-drained soils of low natural fertility (USDA 1959). Soil nutrient analysis by Hicks and Frank (1984) in an adjacent watershed found low levels of major plant nutrients in the A and B horizons, and substantial iron and manganese. Precipitation is quite acidic; average annual $\mathrm{pH}$ was 3.9 for the period 1984-1999, and nitrate deposition for the same period averaged $13.8 \mathrm{~kg} \mathrm{ha}^{-1} \mathrm{yr}^{-1}$ (Rentch and Hicks, in press).

The stand is located on a northeast-facing upper slope position at an elevation of $640 \mathrm{~m}$; slope-inclination ranged from 0-15\%. Annual precipitation averages $129.4 \mathrm{~cm}$ and is fairly evenly distributed throughout the year. The average annual mean temperature is $9.0^{\circ} \mathrm{C}$, although temperatures as low as $-33.9^{\circ} \mathrm{C}$ have been recorded in January (Carvell 1983). The frost-free season averages 167 days (April 30-October 10; USDA 1959).

At the time of treatment (1982) the stand was an overstocked (Gingrich 1967), secondgrowth forest, approximately 55 years old. Site index is $21.3 \mathrm{~m}$ for northern red oak (base age 50). Pre-treatment stand conditions averaged $31.7 \mathrm{~m}^{2} \mathrm{ha}^{-1}$ basal area and 618 tree ha ${ }^{-1}(\mathrm{dbh} \geq 10$ cm) (Graves et al. 2000). Yellow-poplar (Liriodendron tulipifera L.) was the dominant species in the stand, followed by red oaks (Quercus rubra, $Q$. coccinea Muench., $Q$. velutina Lam.), white oaks (Quercus alba L., Q. prinus), and red maple (Acer rubrum L.). Northern red oak was the dominant red oak, and chestnut oak was the most abundant white oak.

Initial study design (1982). In 1982, a thinning study was conducted using 201.2 ha experiment units, with a 0.2 ha permanent plot located in the center of each experimental unit (all 
information about the original experimental design is from Lamson et al. [1990]). Three thinning treatments $(45 \%, 60 \%$, and $75 \%$ relative density; [Gingrich 1967]) and an uncut control were randomly assigned to the experimental units, resulting in five replications of each treatment. After five growing seasons (1986), all trees were remeasured and all crop trees were assigned a free-to-grow (FTG) rating. Crop trees were defined as vigorous, dominant and codominant tree of commercial species with a potential Grade 1 butt log, with no more than three epicormic branches, and no significant decay in the main stem. Free-to-grow means that there is enough space (more than $1.5 \mathrm{~m}$ ) between the crop tree crown and adjacent crowns that the canopy will not close in the subsequent five years. FTG ratings were assigned from 0 (no crown release) to 4 (crown fully released) in increments of 0.5 . For the current study, FTG ratings were converted to percent of crown released in $12.5 \%$ increments.

Increment core collection and preparation. Because this study is part of a larger study of old-growth oak forests, only dominant and codominant red oak $(n=51)$ and chestnut oak $(n=$ 52) crop trees were selected for coring. In the 1982 study, all trees $\geq 2.5 \mathrm{~cm}$ dbh were tagged for long-term monitoring. For this study, a random sample of dominant/codominant trees were cored to provide response data by release level. Sample trees were randomly selected from a master list of all crop trees by their level of crown release assigned during the first remeasurement in 1986, and without regard to the three thinning levels. Trees were cored in each of the eight crown release $(\% \mathrm{CR})$ levels $(12.5 \%, 25 \%, 37.5 \%, 50 \%, 67.5 \%, 75 \%, 87.5 \%$, $100 \%)$ and a control. Two cores were extracted at breast height $(1.37 \mathrm{~m})$ from each sample tree. The minimum target subsample size for each release level was five, although this could not be attained in some cases because of low numbers of suitable crop trees in the target crown-release group. To increase sample size, trees were pooled into four crown release levels: $25 \%, 50 \%$, 
$75 \%, 100 \%$, and a control. Quadratic mean diameters of the sample trees were $34.5 \mathrm{~cm}$ for red oak, and $24.6 \mathrm{~cm}$ for chestnut oak.

Cores were dried, mounted and then sanded with progressively finer grit sandpaper to expose the annual rings (Stokes and Smiley 1968). Growth ring widths were measured to the nearest $0.001 \mathrm{~mm}$ using a Leica Stereo Zoom-5 binocular microscope, an Acu-rite measuring stage, and a Quik-Chek 1000 digital readout, in conjunction with J2 $\mathrm{X}^{\circledR}$ software. Tree-ring series were cross-dated using marker years based on consistently narrow rings (e.g., 1953, 1959, 1988), and dating was validated using the program COFECHA (Grissino-Mayer et al. 1997).

Data analysis. For the climatic portion of the study, age- and diameter-related radial growth trends were removed from each tree-ring series using the program ARSTAN (Cook and Holmes 1986). ARSTAN produces chronologies by detrending each series, and then applying a robust estimation of the mean value function to yield a series with a mean of one and equal variance. I used the modified negative exponential model as the detrending method because of its compatibility to the decreasing pattern found in most ring-width series (Cook and Peters 1997). The program first creates a ring-width index (RWI) for each tree, and then an autoregressive model was used to account for autocorrelation in each RWI. In this study, the first-order autoregressive model was sufficient to account for autocorrelation.

I then used a response function analysis to estimate the effect of 32 climatic variables on the radial growth response (RWI) of northern red oak and chestnut oak. Monthly values of total precipitation and mean temperature for June-December of the previous year and JanuarySeptember of the current year were selected as predictors. Precipitation and temperature data from 1973 to the present were recorded at the Cooper's Rock weather station on site, and data for 
the years 1932-1973 were interpolated from records from the three closest weather stations. Climatic data were obtained from the National Climate Data Center (NCDC).

Response functions were derived using the method of principal components regression (Fritts et al. 1971; Fritts 1976). This method accounts for strong multicollinearity among monthly climatic variables and permits an assessment of the independent effects of each variable. With this method, the original climatic variables are transformed into a new set of uncorrelated variables called principal components of the correlation matrix. This transformation ranks the new uncorrelated variables in order of their importance, and the procedure then involves eliminating some of the principal components to achieve a substantial reduction in variance. I used the eigenvalue product rule (Guiot et al. 1982) to eliminate the last eight principal components, and the remaining 24 components were further screened using stepwise regression with an F-to-enter value of 0.15, commonly used in dendroclimatic studies (Fritts 1976; Lindholm et al. 2000). A multiple regression analysis of the response variable against the reduced set of principal components was then performed, using ordinary least squares estimation. Once the regression coefficients for the reduced set of orthogonal variables were calculated, they were mathematically transformed into a new set of coefficients that corresponded to the original correlated set of variables. A 0.05 significance level was used to identify statistically significant climatic predictors.

The correlation matrix of climatic predictors, the eigenvectors of this matrix, and the uncorrelated principal components were computed using the SAS program (SAS Inst. Inc. 1998). Normality of the data was tested using the normal probability plot (Q-Q) generated in SAS, and independence was tested by plotting the residuals against time and against their lagged values. In both cases the data conformed to the two assumptions. 
The proportion of variance $\left(\mathrm{R}^{2}\right.$-climate) of each species' chronology attributable to the 32 climatic variables used was calculated using the following equations:

$$
\begin{array}{ll}
\mathrm{SS}_{\text {Regression }} & =\mathrm{SS}_{\text {Total }}-\mathrm{SS}_{\text {Residuals }} \\
\mathrm{R}_{\text {climate }}^{2} & =\mathrm{SS}_{\text {Regression }} / \mathrm{SS}_{\text {Total }}
\end{array}
$$

Response functions were calculated separately for each species using their entire data set, and then for each crown-release group $(0 \%, 25 \%, 50 \%, 75 \%, 100 \%)$, to see if the $\mathrm{R}^{2}$ (climate) value changed as a function of crown release.

For the disturbance history portion of the study I used the technique of Nowacki and Abrams (1997) with several modifications. Although basal area increment provides a better means of comparing the absolute growth among stands, the focus of this study was on detecting relative radial growth changes within individual trees over short time periods to identify canopy disturbances affecting that tree. Thus the average of ring-widths from two increment cores per tree was the input for the \%GC calculation.

I first calculated \%GC values for each tree using equation 1 for years 1983, 1984, and 1985 (lag of 1 to 3 years) and for time intervals $\left(M_{1}, M_{2}\right)$ ranging from 6 to 15 years. I then analyzed the entire data set, by species, using the General Linear Model Procedure (PROC GLM; SAS Inst. Inc. 1998) to test for statistically significant relationships between \%GC and \% crown release (\%CR). In order to see if different combinations of lag and time interval better expressed this relationship, I also included lag and interval, as well as their interaction, as independent variables in the analysis. When lag or interval showed a significant effect, I used Fisher's Least Significant Difference (LSD) to identify which level of lag and/or interval produced statistically different mean \%GC values. Finally, for each species, I ran each combination of lag and interval individually using PROC-GLM. In order to see if the trend between release level and \%GC was 
linear, quadratic, or cubic, I used one degree of freedom orthogonal comparisons. Orthogonal comparisons are a priori tests that divide the treatment SS into independent parts (Dowdy and Wearden 1991). The outputs are F statistics and equations of each model. When the appropriate F statistic was significant, the significance of the coefficients $\left(b_{n}\right)$ were tested using a t-test.

\section{Results}

Climate and radial growth. Response functions for northern red oak and chestnut oak are shown in Figures 3.1 and 3.2. Of the 32 climatic variables considered, a total of eight temperature and six precipitation variables were statistically significant. The overall trends of response functions for the two species were similar. Correlation values for precipitation were generally positive, and had greater absolute values than those for temperature. Growing season climatic predictors were also more numerous, and greater in absolute value than those of the dormant season. Both species showed significant negative correlations between radial growth and previous-August and previous-December temperature, as well as previous September precipitation. Correlations with June precipitation and radial growth for both species yielded the highest positive values, results that conform to nearly all dendroclimatic studies of oaks (e.g., Estes 1970; Asby and Fritts 1972; Jacobi and Tainter 1988; Pan et al. 1997; Rubino and McCarthy 2000). Both species also showed a strong negative correlation with June temperature, although the relationship was statistically significant for red oak only.

The small number of significant correlations between these climatic variables and growth, and their low values, illustrate the relative climatic complacency of these species on this site. Mean sensitivity, a statistical measure of the mean change from each measured annual ring 
width value to the next, and a measure of how much annual variations in precipitation and temperature limit growth on a site (Fritts 1976), were relatively low (0.19 and 0.22 for northern red oak and chestnut oak, respectively). A comparison of the $\mathrm{R}^{2}$ (climate) values from the principal components regression for the released and unreleased groups suggests the comparative importance of climatic and non-climatic factors to radial growth in this forest. $\mathrm{R}^{2}$ (climate) generally declined as the level of crown release increased (Table 3.1). The proportion of ringwidth variation attributable to climate for the chestnut oak and red oak control groups (10.6\% and $35.9 \%$, respectively) was 2 to 3 times greater than the average of the released groups (4.5\% and $8.8 \%$ ). Differences were more pronounced for red oak, a species that is generally considered both more climatically sensitive (Parker et al. 1982; Abrams et al. 1998) and more opportunistic in favorable environmental conditions (Dickson 1994; Hicks 1998). For both species, climate, while exerting a significant influence on annual tree-ring variation, was comparatively less influential than non-climatic events such as crown release and canopy disturbance.

Canopy disturbances and radial growth averaging. The relationship between \% CR and \% GC was highly significant for both species for all lags and all intervals (Table 3.2). Lag and interval did not show a significant effect for red oak, suggesting that the strong relationship between $\% \mathrm{GC}$ and $\% \mathrm{CR}$ for this species was present regardless of the lag and interval used in the calculation of $\% \mathrm{GC}$. For chestnut oak, both lag and interval were statistically significant. The best fit between \%GC and \%CR occurred when a shorter time interval (7-year) and a longer lag (3-year) were used, however the interaction of lag and interval was not significant $(\mathrm{p}=$ 0.998). The 3-year lag does not imply that chestnut oak delays its response to canopy release for three years. Plots of raw ring-widths (Figures 3.3a and 3.4a) show radial growth increases for 
both species in 1983, the first year following thinning. However, use of the 3-year lag best captures the maximum average $\% \mathrm{GC}$ for chestnut oak.

Plots of \%GC for northern red oak (using a 1-year lag and 10-year interval) and chestnut oak (3-year lag and 7-year interval) are shown in Figures 3.3b and 3.4b for the period 19701990. Two features of these plots are important. First, radial growth averaging provides a fairly accurate estimation of the disturbance year. Peak \%GC for chestnut oak correctly identified the disturbance year as 1982, while red oak's peak \%GC occurred one year later for all \%CR levels except the $100 \%$ level. Second, the trend of increasing \%GC associated with increased levels of crown release is also apparent, particularly for chestnut oak. On average, each $25 \%$ increment of crown release yielded $26 \%$ GC for chestnut oak and 20\% GC for red oak. When the response of the two species was analyzed for each individual combination of lag and interval, the relationship between \%GC and \%CR was best approximated by a straight line $(\mathrm{y}=\mathrm{a}+\mathrm{b} * \mathrm{x}$, where $\mathrm{y}=\% \mathrm{GC}$, and $\mathrm{x}=\% \mathrm{CR}$ ) (Table 3.3; note, only data for intervals of 7 to 12 years are shown). The coefficient of the linear model (b) was $0.95(\mathrm{t}=3.62, \mathrm{p}<0.001)$ and $1.10(\mathrm{t}=5.21$, $\mathrm{p}<0.0001$ ) for red oak and chestnut oak at interval and lag shown in Figures 3.3 and 3.4, and varied between 0.74 and 1.23 over all lag periods and intervals. Using the 1-year lag and 10-year interval as proposed by Nowacki and Abrams (1997), the coefficient for chestnut oak was 0.92, not greatly different from the 3-year lag and 7-year interval. These results provide evidence of an approximate 1:1 relationship between $\% \mathrm{GC}$ and $\% \mathrm{CR}$ for these 55 year-old trees, and suggest that the magnitude of \%GC is highly correlated with disturbance severity.

The increases were synchronous and anamorphous, with several exceptions. Peak \%GC in the $25 \%$ crown release group for chestnut oak was delayed until 1984. Red oak achieved maximum \% GC in the $75 \%$ crown release level in 1983, while \% GC did not peak in the $100 \%$ 
crown release group until 1985, and at a slightly lower value. The small sample of red oaks in the $100 \%$ crown release level $(n=6)$ may be responsible for this anomaly. The fact that chestnut oak in the control group (i.e., no release) showed a positive \%GC (19\%) in 1982 is probably due to the fact that 7 of the 10 sample trees in this group occurred in experimental units that were thinned to a relative density of $75 \%$. Although some chestnut oak control trees were not "control" in the strictest sense, their growth change was modeled as a function of changes in each tree's immediate environment (i.e., level of crown release), and all control chestnut oaks met the criterion of zero crown release. In addition, relative density levels were plot averages, and do not necessarily indicate density level in the immediate environment of any particular tree. In contrast, all the red oak control trees occurred in unthinned experimental units where only natural mortality unassociated with the treatment occurred.

\section{Discussion}

Climatic response. The strongest correlations between radial growth and climate occurred during August and September of previous year, and June of the current year. This trend is consistent with the determinate (Marks 1975) or preformed (Oliver and Larson 1996) growth type, [although note that red oak has also been classified as semi-determinate; Tomlinson et al. 1991, or episodic; Dickson 1994). Previous-year climate is important because buds that are formed at the end of the growing season contain primordia of all the tissues that will expand during the subsequent growing season, and carbohydrates stored in the previous year fuel next year's initial extension growth (Kozlowski and Keller 1966; Marks 1975; Bormann and Likens 1979). The first significant correlation for current growing season climate occurred for June 
precipitation and temperature, when "spring" gives way to "summer." Oaks complete their addition of early wood by the time of leaf-out (Kennedy and Sutherland 1999), mid-May in the central Appalachian region, when stored food reserves from the previous growing season largely determine growth (Hinckley et al. 1979). Beginning in June, growth depends more on currentlyproduced than previously-accumulated photosynthates, and competition for photosynthates by more active sinks in other parts of the tree occurs (Hinckley et al. 1976). Consistent with this process are strong negative correlations between radial growth and June temperature for both species (although the relationship was statistically significant only for red oak). High summer temperatures have been linked to reduced radial growth due to high rates of leaf transpiration and soil water evaporation, which together produce water stress premature stomatal closure (Fritts 1976; Hinckley et al. 1979), as well as increased respiration and reduced rates of assimilation and hormone synthesis (Kramer and Kozlowski 1960; Fritts 1976). Cooler June temperatures, in contrast, allow net photosynthesis to continue at a high rate (Jacobi and Tainter 1988).

Radial growth of both species showed negative and significant correlations with previous-September precipitation and previous-August temperature. On well-drained, mid-slope sites, negative correlations between growth and precipitation during the growing season are difficult to explain. Pan et al. (1997) and Jacobi and Tainter (1988) found a similar response for northern red oak and white oak, respectively, so this correlation is probably not an artifact of the response function analysis. Fritts (1976) reasoned that this may be a case in which growth and precipitation are less directly and causally related to each other, than both related to another physiological factor, for example, cold hardiness. Conditions that initiate cold hardening include low temperatures and short days, however water stress may also trigger this process (Fritts 1976; Carter and Brenner 1985). While a dry autumn may cause water stress and interrupt current-year 
growth, early cold hardening reduces the susceptibility of primordial tissue to early fall frost and severe winter cold, and results in greater survival of buds. In contrast, cooler than average August temperatures may extend the growing season, reduce respiration, and permit greater accumulation of stored food reserves for the following growing season (Jacobi and Tainter 1988). Thus while cool August temperatures increase food production, dry Septembers favor bud survival.

Radial growth averaging, The dendroclimatic analysis shows that the radial growth of oaks is indeed affected by climate, but the influence of climate assumes relatively less importance as trees undergo canopy disturbance and crown release (Table 3.1). A critical component of successful radial growth averaging is the selection of a time interval that is long enough to average out high-frequency, short-term climatic responses, while capturing intermediate-length growth increases (i.e., 7-12 years) that are associated with canopy disturbances (Nowacki and Abrams 1997). The efficiency with which the radial growth averaging technique emphasizes intermediate-length growth changes while de-emphasizing interannual effects of climatic fluctuations is evident from the species' ring-width and \%GC curves (Figures 3.3, 3.4). In 1988, the study site experienced a severe drought, during which June precipitation was $45 \%$ of normal values, and Palmer Drought Severity Indices for the period June-July averaged -3.9 (NCDC 2000). Trees of both species in all crown release levels showed a large growth decline in 1988 (Figures 3a, 4a), but pre-drought growth levels of both species resumed the following year. For chestnut oak, the large fluctuation in radial growth between 1987-1989 was not evident in the \%GC curve (Figure 3.4a). For red oak, there was a small spike in 1988, but the increase was not of sufficient magnitude (6-10\% increase over the prior year) to be mistaken for a canopy disturbance (Figure 3.3a). 
In view of the different growth characteristics of these two species, some measure of species-specific averaging criteria may appear warranted. For example, a delayed response and a shorter duration of the response are consistent with chestnut oak's overall growth characteristics. Northern red oak outgrows nearly all other oaks in radial growth (Trimble 1969), as well as height extension and lateral expansion (Hicks 1998). When trees of good vigor on better sites are compared, chestnut oak is often over-topped and out-competed by more rapidly growing species such as northern red oak and yellow-poplar (Trimble 1960; McQuilken 1990). Yetter and Runkle (1986) found red oak height growths of $0.19 \mathrm{~m} / \mathrm{yr}$ in gaps, while the average lateral expansion of red oak crowns in openings was $0.16 \mathrm{~m} / \mathrm{yr}$ in both 16 year-old (Miller 2000) and 45-50 year-old second growth stands (Trimble and Tryon 1966). In comparison, chestnut oak has a relatively smaller live crown (Hicks 1998$)$, and a lower crown expansion rate $(0.12 \mathrm{~m} / \mathrm{yr}$; Miller 2000). Comparing northern red oak, black oak, and white oak, Graney (1987) found that a more rapid response of intermediate and higher crown class red oak to thinning was probably due to differences in competitive crown size and position in overstocked stands. Red oaks were in better condition to respond, and tended to reach dominant crown positions earlier and sustain growth increases longer than other oaks.

Initial tree size and stand characteristics also may influence response time and the magnitude of \%GC. More highly stocked stands may show a greater response than lightly stocked ones (Trimble 1968), and the rate of crown closure is faster on better quality sites (Gingrich 1967; Hilt 1979). However, if crown class is controlled, response is independent of initial tree size (Ellis 1979; Trimble 1969; Singer and Lorimer 1997), and basal-area density (Trimble 1969). 
An added question concerns the degree to which tree age may dampen the response to crown release and increase climatic sensitivity. For this study, the importance of this question may be underestimated by the low average tree age ( 55 years at time of treatment), and the fact that a relatively large portion of their age occurred during and after the treatment. As trees age and increase in height, girth, and crown size, the ratio of photosynthetic and nonphotosynthetic tissue usually decreases (Barnes et al. 1998), making them more susceptible to climatic, physical, or other forms of stress (Waring 1987). In taller, older trees, the efficiency of water and nutrient transport may also decrease, due to tissue changes associated with age, size, and carbon balance (Ryan and Yoder 1997). As a result, premature stomatal closure and reduced growth may occur not because of climatic drought, but due to the inability to move water rapidly enough from the roots to leaves. Recognizing the reduced growth potential of older trees, common recommendations are to stop thinnings in oak stands on average sites ( $\mathrm{SI}=17-23$ for red oak) at ages 60-70 in the central states (Roach et al. 1968) and at age 95 in New England (Ward 1991). Comparing 5-year growth of free-to-grow versus unreleased 75-80 year-old hardwood sawtimber trees, Smith and Miller (1991) found a 44\% increase for red oak, and a 56\% increase for white oak, but no significant difference was found between diameter increase of released and nonreleased chestnut oak. Because of the potentially more conservative nature of older, overstory oaks, Nowacki and Abrams (1997) suggested that a 35-40\% crown release may be required to elicit a $25 \%$ GC for presettlement-era oaks.

In this study, the relationship between $\% \mathrm{CR}$ and $\% \mathrm{GC}$ for 55 year-old overstory oaks was linear and approximately $1: 1$, and the $25 \%$ GC value was a suitable threshold for detecting minimal (one-side) release events. Perkey and Onken (2000) found a similar relationship between growth and release for 55 year-old red oak crop trees. In Wisconsin, Singer and 
Lorimer (1997) also found a linear relationship between crown release and growth for 42-243 year-old sugar maple, but not for white ash (Fraxinus americana L.) or black cherry (Prunus serotina Ehrh.). However, Ellis (1979) found that fully released 85-year old sugar maple had a mean diameter growth increase of $94 \%$, comparable to the response in our study. Finally, looking at the 100 largest oak trees ha ${ }^{-1}$ (age 35-100 yr), Hilt (1979) found that the heavier the thinning, the greater the response. Younger stands responded somewhat better than older ones, but he attributed that to the interaction between age and stocking. Crown class, rather than age, site (Hilt 1979), vigor, initial dbh, stocking, or site quality (Trimble 1969) was most closely correlated with diameter increase. Further, as stands age, they potentially become more diverse in composition, age-distribution, and canopy stratification, and crown class becomes a more reliable predictor of response to thinning and disturbance.

Limitations of radial growth averaging. As a growth model, the percent growth change method evaluated in this study is not intended to account for the wide range of ecological processes associated with either silvicultural thinning or "natural" gap disturbances. Tree mortality initiates a suite of biotic responses and environmental changes that include, in addition to increased crown exposure and lateral extension of gap border trees (Runkle 1985), understory initiation and/or release (Runkle 1982; Lorimer and Frelich 1989), microsite changes in temperature and humidity (Beatty and Stone 1985), as well as altered rates of decomposition, nutrient cycling, and energy exchange (Sprugel 1985; Vitousek 1985). In fact, if understory dynamics are the primary focus, the criteria of Lorimer and Frelich (1989) provide the best means of identifying canopy accession events. We were less interested in larger stand-level changes associated with reductions in residual density than the radial growth response of individual codominant trees bordering canopy openings. In this sense, our study more closely 
resembles crop-tree release studies. Thus, our use of the model is aimed at 1) capturing a limited specific portion of the total change that occurs during crown release, 2) evaluating the model's accuracy in identifying a time period when known canopy disturbances of know magnitude occurred, and 3) establishing its utility as a method of reconstruction canopy disturbance history. Depending on the lag selected, the radial growth averaging method assumes that the response occurs 1 to 3 years after the canopy disturbance. However response-time may vary according to the precise timing of the disturbance event. For example, a disturbance in January may precede the growing season enough for a growth increase to occur in the same calendar year, while one in July, after most of the radial growth is complete, would not be apparent until the following year. This factor may be more apparent for northern red oak than chestnut red oak, because of the former's episodic flushing growth habit (Dickson 1994). Differences in individual tree genetics and physiological condition before the disturbance, as well as specieslevel differences may also temper the precise timing of the response (Lorimer and Frelich 1989; Schuler and Fajvan 1999).

If the technique is used to construct a site disturbance chronology, some caution should be exercised in attributing \%CG evidence of a disturbance in two or more proximate trees to the same disturbance event. This may not always be the case; for example, in this region, high velocity, localized, and short duration windstorms associated with thunderstorms are a common form of canopy disturbance (Romme and Martin 1992; NCDC 2001), and more than one disturbance may occur in a sample plot in the same year (Fajvan and Seymour 1993).

Finally, while most evidence supports the assertion that interannual variability in climate is the dominant climatic signal in eastern mesic forests, there is some evidence that longer-term climatic trends may be present. Long-term, non-periodic trends such as global warming, for 
example, may increase drought frequency (LeBlanc and Foster 1992) and alter species distributions (Iverson et al. 1999). In addition, current European research suggests that some climatic trends may operate on frequencies comparable to intervals used in radial growth averaging. For example, the North Atlantic Oscillation is an intermittent climate oscillation with temporally active and passive phases. Periods of 5 to 7,9 to 11,12 to 14 , and 80 to 90 years have been identified (Appenzeller and Stocker 1998). Although this phenomenon has been linked to winter climate and phenology of herbaceous plants in Europe (Post and Stenseth 1999; Otterson et al. 2001), its effects in North America have yet to be demonstrated

Applications. The radial growth averaging method is generally applicable in temperate closed canopy forests where competition for sunlight overshadows the effects of climate (Nowacki and Abrams 1997). Theoretically, the technique is applicable to any species that can withstand side-shade and that can profit from partial crown release. Thus, for example, the model would probably apply to species such yellow-poplar (Carvell 1964; Beck and DellaBianca 1975), but not to black cherry (Trimble 1968; Miller et al. 1995). In old-growth forests, stand-wide disturbance years indicated by \%GC values for older (> 100 years) hickories and white ash closely agreed with those for white oak, northern red oak, and chestnut oak (Rentch, manuscript in preparation). For this study, a $25 \%$ growth change threshold appears to identify crown release events for two oak species. For other species with different growth rates and release-response characteristics, further research that quantifies the relationship between crown release and radial growth is indicated.

The percent growth change method is particularly applicable in eastern forests where oaks comprise a significant portion of the canopy. Here, problems with oak regeneration on better quality sites have stimulated research into conditions that facilitated previous oak 
establishment. Fire chronologies of older oak forests comprise one approach to estimating ground-level disturbance (Sutherland 1997; Abrams 2000). The percent growth change model can supplement fire history by estimating the historical range of variability of canopy disturbance over a similar time period. When cored-tree locations are mapped, individual tree chronologies from several overstory species and cohorts over a relatively long time period (i.e., several hundred years) can be integrated into a temporal and spatial approximation of the disturbance regime. In fact, for many older forests with only sketchy historical records, this method may be the only way to reconstruct long-term stand dynamics. This estimate may provide a framework for scheduling the rate of stand entry for silvicultural treatments (e.g., thinning) that is consistent with its historic stand development.

\section{Conclusion}

In oak-dominated forests of eastern North America, where individual and multiple treefall gaps comprise the dominant disturbance regime, the influence of climate is primarily expressed as short-term variations in radial growth that rarely last more than one year. Competition for growing space dominates growth, and the effect of climate is often overshadowed by canopy disturbances that alter the competitive balance and the distribution of resources. In such a disturbance regime, radial growth averaging is a suitable method for estimating the frequency and intensity of canopy disturbances, and the $25 \%$ GC threshold provides a good indication that a small, single-tree event has occurred. The applicability of this method to non-oak species is suggested, however more research quantifying the relationship between percent growth change and percent crown release is indicated. Using this method, 
individual tree and standwide chronologies may be readily determined, and when combined with spatial analysis, species-, and group-dynamics can be chronicled. If old-growth trees are available, radial growth averaging makes a comparison of disturbance regimes over a long historical period possible. When combined with fire chronologies, the method provides a useful tool in estimating the historic range of variability of canopy disturbance, and may provide the best method of estimating long-term stand dynamics when the historical record (land surveys, human use, etc.) is lacking. 


\section{Acknowledgements}

Dr. Jimmie Colbert, USDA Forest Service, initially suggested this study, and assisted in the study design and analysis. Dr. Gary Miller, USDA Forest Service, graciously provided field data from the 1982 thinning trials. A version of this chapter has been accepted by the Canadian Journal of Forest Research. Coauthors are Dr. Fekedulegn Desta and Dr. Gary Miller. 
Literature cited

Abrams, M. D. 2000. Fire and the ecological history of oak forests in the eastern United States. In Yaussey, D. A. comp. Proceedings: workshop on fire, people, and the central hardwoods landscape. USDA For. Ser. Gen. Tech. Rep. NE-247.

Abrams, M. D., Orwig, D. A., and Dockry, M. J. 1997. Dendroecology and successional status of two contrasting old-growth forests in the Blue Ridge Mountains, U.S.A. Can. J. For. Res. 27: 994-1002.

Abrams, M. D., Ruffner, C. M., and Morgan, T. A. 1998. Tree-ring responses to drought among species and contrasting sites in the Ridge and Valley of central Pennsylvania. For. Sci. 44: 550558.

Appenzeller, C., and Stocker, T. F. 1998. North Atlantic Oscillation dynamics recorded in Greenland ice cores. Science 282: 446-449.

Ashby, W. C., and Fritts, H. C. 1972. Tree growth, air pollution, and climate near LaPorte, Indiana. Bull. Amer. Meteorol. Soc. 53: 246-251.

Barden, L. S. 1980. Tree replacement in small canopy gaps of a cove hardwood forest in the southern Appalachians. Oikos 35: 16-19.

Barden, L. S. 1981. Forest development in canopy gaps of a diverse hardwood forest in the southern Appalachian Mountains. Oikos 37: 205-209.

Barnes, B. V., Zap, D. R., Denton, S. R., and Spurr, S. H. 1998. Forest ecology. $4^{\text {th }}$ edition. John Wiley and Sons, New York, NY.

Beatty, S. W., and Stone, E. L. 1986. The variety of soil micro sites created by tree falls. Can. J. For. Res. 16: 539-548.

Beck, D. E., and Della-Bianca, L. 1975. Growth and yield of thinned yellow-poplar. USDA For. Ser. Res. Pap. SE-123.

Bormann, F. H. and Likens, G. E. 1979. Pattern and process in a forested ecosystem. SpringerVela, New York, NY.

Brubaker, L. B. 1987. Forest disturbance and tree-ring analysis. In Jacoby, G. C., and Horn beck, J. W., comps. Proceedings of the International Symposium on Ecological Aspects of Treering Analysis, 17-21, August 1986, Tarrytown, NY. U. S. Dept. of Energy, Washington, D. C. pp. 101-118.

Buell, M. F., Buell, H. F., and Small, J. A. 1954. Fire in the history of Mettler's Woods. Bull. Torrey Bot. Club. 81: 253-255. 
Canham, C. D., Denslow, J. S., Platt, W. J., Runkle, J. R., Spies, T. A. and White, P. S. 1990. Light regimes beneath closed canopies and tree-fall gaps in temperate and tropical forests. Can. J. For. Res. 20: 620-631.

Canham, C. D., and Burbank, D. H. 1994. Causes and consequences of resource heterogeneity in forests: interspecific variation in light transmission by canopy trees. Can. J. For. Res. 24: 337-349.

Carter, J. V., and Brenner, M. L. 1985. Plant growth regulators and low temperature stress. In Paris, R. P., and Reid, D. M., eds. Encyclopedia of plant physiology, new ser. V 11. SpringerVerlag, Berlin, Germany. pp. 418-443.

Carvel, K. L. 1964. Improvement cuttings in immature hardwood stands yield income while increasing future saw timber sales. W. Va. Univ. Agric. Exp. Stun. Bull. 492, 17p.

Carvell, K. L. 1983. A summary of 1973-1982 weather data from the West Virginia University Forest. W. Va. Univ. Agric. Exp. Stun. Bull., Morgantown, WV. West Virginia Forestry Notes, Circular 123.

Cho, D. S., and Boerner, R. E. 1991. Canopy disturbance patterns and regeneration of Quercus species in two Ohio old-growth forests. Vegetatio 93: 9-18.

Cook, E. R. 1987. The decomposition of tree-ring series for environmental studies. Tree-Ring Bull. 47: 37-59.

Cook, E. R., and Holmes, R. L. 1986. Guide to computer program ARSTAN. In Holmes, R. L., Adams, R. K., and Fritts, H. C. eds. Tree-ring chronologies of western North America: California, eastern Oregon and northern Great Basin. Laboratory of Tree-ring Research, Univ. of Arizona, Tucson, AZ.

Cook, E. R., and Jacoby, G. C., Jr. 1977. Tree-ring-drought relationships in the Hudson Valley, New York. Science 198: 399-401.

Cook, E. R., and Kairiukstis, L. A., editors. 1990. Methods of dendrochronology: applications in the environmental science. International Institute for Applied Systems Analysis. Kluwer Academic Publishers, Dordrecht, The Netherlands.

Cook, E. R., and Peters, K. 1997. Calculating unbiased tree-ring indices for the study of climatic and environmental studies. The Holocene 7: 361-370.

Cutter, B. E., Lowell, K. E., and Dwyer, J. P. 1991. Thinning effects on diameter growth in black and scarlet oak as shown by tree ring analyses. For. Ecol. Manage. 43: 1-13.

Dale, M. E., and Sonderman, D. L. 1984. Effect of thinning on growth and potential quality of young white oak crop trees. USDA For. Ser. Res. Pap. NE-112. 
Dickson, R. E. 1994. Height growth and episodic flushing in Northern red oak. In Isebrands, J. G. and Dickson, R. E.,comps. Biology and silviculture of Northern red oak in the north central region: a synopsis. USDA For. Ser. Gen. Tech. Rep. NC-173.

Dowdy, S. and Weardon, S. 1991. Statistics for research. John Wiley and Sons, New York, NY.

Ellis, R. C. 1979. Response of crop trees of sugar maple, white ash, and black cherry to release and fertilization. Can. J. For. Res. 9: 179-188.

Estes, E. T. 1970. Dendrochronology of black oak (Quercus velutina Lam.), white oak (Quercus alba L.), and shortleaf pine (Pinus echinata Mill.) in the central Mississippi Valley. Ecol. Monogr. 40: 295-316

Fajvan, M. A., and Seymour, R. S. 1993. Canopy stratification, age structure, and development of multicohort stands of eastern white pine, eastern hemlock, and red spruce. Can. J. For. Res. 23: $1799-1809$.

Foster, D. R. 1988. Disturbance history, community organization and vegetation dynamics of the old-growth Pisgah Forest, south-western New Hampshire, U.S.A. J. Ecol. 76: 105-134.

Fritts, H. C. 1976. Tree rings and climate. Academic Press, New York, NY.

Fritts, H. C., Blasing, T. J., Hayden, B. P., and Kutzback, J. E. 1971. Multivariate techniques for specifying tree-growth and climate relationships and for reconstructing anomalies in paleoclimate. J. Appl. Meteorol. 10: 845-864.

Gingrich, S. F. 1967. Measuring and evaluating stocking and stand density in upland hardwood forests in the central states. For. Sci. 13: 38-53.

Graney, D. L. 1987. Ten-year growth of red and white oak crop trees following thinning and fertilization in the Boston Mountains of Arkansas. In Proceedings, Fourth Biennial Southern Silvicultural Research Conference, 4-6 November, 1986, Atlanta, Georgia. USDA For. Ser. Gen. Tech. Rep. SE-42.

Graves, A. T., Fajvan, M. A., and Miller, G. W. 2000. The effects of thinning intensity on snag and cavity tree abundance in an Appalachian hardwood stand. Can. J. For. Res. 30: 1214-1220.

Griot, J., Berger, A. L., and Manaut, A. V. 1982. Response functions. In Hughes, M. K., Kelly, P. K, Pilcher, J. R., and LaMarche, V. C., eds. Climate from tree rings, 7-11 July, 1980, Norwich, UK. Cambridge University Press, Cambridge, England.

Grissino-Mayer, H. D., Holmes, R. L., and Fritts, H. C. 1997. The international tree-ring data bank program library version 2.1 user's manual. Laboratory of Tree-Ring Research, Univ. of Arizona, Tuscon, AZ. 
Henry, J. D., and Swan, J. M. A. 1974. Reconstructing forest history from live and dead plant material - an approach to the study of forest succession in southwest New Hampshire. Ecology 55: 772-783.

Hicks, R. R., Jr. 1998. Ecology and management of central hardwood forests. John Wiley and Sons, New York, NY.

Hicks, R. R., Jr., and Frank, P. S. 1984. Relationship of aspect to soil nutrients, species importance and biomass in a forested watershed in West Virginia. For. Ecol. Manage. 8: 281291.

Hilt, D. E. 1979. Diameter growth of upland oaks after thinning. USDA For. Ser. Res. Pap. NE-437.

Hinckley, T. M., Thompson, D. R., McGinness, N. P., and Hinckley, A. R. 1976. Stem growth and phenology of a dominant white oak. In Fralish, J. S., Weaver, G. T., and Schlesinger, R. C., eds. Proceedings of the $1^{\text {st }}$ Central Hardwood Forest Conference, Southern Illinois Univ., Carbondale, Ill. pp. 187-202.

Hinckley, T. M., Dougherty, P. M., Lassoie, J. P., Roberts, J. E., and Teskey, R. O. 1979. A severe drought: Impact on tree growth, phenology, net photosynthetic rate and water relations. Am. Midl. Nat. 102: 307-316.

Iverson, L. R., Prasad, A. M., Hale, B. J., and Sutherland, E. K. 1999. An atlas of current and potential future distributions of common trees of the Eastern United States. USDA For. Ser. Gen. Tech. Rep. NE-265.

Jacobi, J. C., and Tainter, F. H. 1988. Dendroclimatic examination of white oak along an environmental gradient in the Piedmont of South Carolina. Castanea 53: 252-262.

Kennedy, K. T., and Sutherland, E. K. 1999. Fire-scar formation and compartmentalization in oak. Can. J. For. Res. 29: 166-171.

Kozlowski, T. T., and Keller, T. 1966. Food relations of woody plants. Bot. Rev. 32: 293-382.

Kramer, P. J. and Kozlowski, T. T. 1960. Physiology of trees. McGraw-Hill, New York, NY.

Lamson, N. I., Smith, H. C., Perkey, A. W., and Brock, S. M. 1990. Crown releases increase growth of crop trees. USDA For. Ser. Res. Pap. NE-635.

Leblanc, D. C., and Foster, J. R. 1992. Predicting effects of global warming on growth and mortality of upland oak species in the midwestern United States: a physiologically based dendroecological approach. Can. J. For. Res. 22: 1739-1752.- 
Lindholm, M., Lehtonen, H., Kolstrom, T., Merilanien, J., Eronen, M., and Timonen, M. 2000. Climatic signals extracted from ring-width chronologies of Scots pine from the northern, middle and southern parts of the boreal forest belt in Finland. Silva-Fennica 34: 317-330.

Lorimer, C. G. 1984. Methodological considerations in the analysis of forest disturbance history. Can. J. For. Res. 15: 200-213.

Lorimer, C. G., and Frelich, L. E. 1989. A methodology for estimating canopy disturbance frequency and intensity in dense temperate forests. Can. J. For. Res. 19: 651-663.

McQuilken, R. A. 1990. Quercus prinus L., chestnut oak. In Burns, R. M. and Honkala, B. H., tech. cords. Silvics of North America, Vol. 2: Hardwoods. USDA For. Ser. Agri. Handb. No. 654. pp. 721-726.

Marks, P. L. 1975. On the relation between extension growth and successional status of deciduous trees of the northeastern United States. Bull. Torrey Bot. Club 102: 172-177.

Miller, G. W. 2000. Effect of crown growing space on the development of young hardwood crop trees. North. J. Appl. For. 17: 25-35.

Miller, G. W., Wood P. B., and Nichols, J. V. 1995. Two-age silviculture-an innovative tool for enhancing species diversity and vertical structure in Appalachian hardwoods. In Eskew, L. G., comp. Proceedings, 1995 National Silviculture Workshop: Forest health through silviculture. USDA For. Ser. Gen. Tech. Rep. RM-267.

Minckler, L. S. 1967. Release and pruning can improve growth and quality of white oak. J. For. 65: 654-655.

National Climate Data Center (NCDC) and National Oceanic and Atmospheric Administration (NOAA). 2000. CLIMVIS Information: Selection criteria for displaying period of record. <htttp:Ilwww.ncdc.noaa.govlonlineprodldrought|xmgrg3.html>

National Climate Data Center (NCDC). 2001. Storm events: query output. <http://www4.ncdc.noaa.gov/cgi-win/wwcgi.dll?wwevent storms>

Nowacki, G. J., and Abrams, M. D. 1997. Radial-growth averaging criteria for reconstructing disturbance histories from presettlement-origin oaks. Ecol. Monogr. 67: 225-249.

Oliver, D. D., and Larson, B. C. 1996. Forest stand dynamics. Update ed. John Wiley and Sons, New York, N.Y.

Orwig, D. A., and Abrams, M. D. 1997. Variation in radial growth responses to drought among species, site, and canopy strata. Tree 11: 474-484.

Ottersen, G., Planque, B., Belgrano, A., Post, E., Reid, P. C., and Stenseth, N. C. 2001. Ecological effects of the North Atlantic Oscillation. Oecologia 128: 1-14. 
Pan, C., Tajchman, S. J., and Kockenderfer, J. N. 1997. Dendroclimatological analysis of major forest species of the central Appalachians. For. Ecol. Manage. 98: 77-87.

Parker, W. C., Pallardy, S. G, Hinckley, T. M. and Teskey, R. O.. 1982. Seasonal changes in tissue water relations of three woody species of the Quercus-Carya forest type. Ecology 63: 1259-1267.

Perkey, A. W., and Onken, A. 2000. A decade at a crop tree demonstation area. USDA Forest Service, NE Experiment Station, Morgantown, WV. For. Management update Issue 20.

Phipps, R. L. 1982. Comments on interpretation of climatic information from tree rings, eastern North America. Tree-Ring Bull. 42:11-22.

Post, E. and Stenseth, N. C. 1999. Climatic variability, plant phenology, and northern ungulates. Ecology 80: 1322-1339.

Rentch, J. S., and Hicks, R. R., Jr. In press. Nutrient fluxes for two small watersheds: sixteenyear results from the West Virginia University Forest. W. Va. Univ. Agric. Exp. Stun. Bull. No. 724.

Roach, B. A., and Gingrich, S. F. 1968. Even-aged silviculture for upland central hardwoods. USDA For. Ser. Agri. Hbook. No. 355.

Romme, W. H., and Martin, W. M. 1982. Natural disturbance by tree-falls in an old-growth mixed mesophytic forest: Lilly Cornett Woods, Kentucky. In Muller, R. N., ed. Proceedings, $4^{\text {th }}$ Central Hardwood Forest Conference, Univ. of Kentucky, Lexington, KY. pp. 367-383.

Rubino, D. L., and McCarthy, B. C. 2000. Dendroclimatological analysis of white oak (Quercus alba L., Fagaceae) from an old-growth forest of southeastern Ohio, U.S.A. J. Torrey Bot. Soc. 127: 240-250.

Runkle, J. R. 1981. Gap generation in some old-growth forests of the eastern United States. Ecology 62: 1041-1051.

Runkle, J. R. 1982. Patterns of disturbance in some old-growth mesic forests of eastern North America. Ecology 63: 1533-1546.

Runkle, J. R. 1985. Disturbance regimes in temperate forests. In Pickett, S. T. A., and White, P. S, eds. The ecology of natural disturbance and patch dynamics. Academic Press, San Diego, CA. pp. 17-33.

Runkle, J. R. 1998. Changes in southern Appalachian canopy gaps sampled thrice. Ecology 79: 1768-1780. 
Ryan, M. and B. Yoder. 1997. Hydraulic limits to tree height and growth: what keeps trees from growing beyond a certain height? BioScience 47: 235-242.

Schlesinger, R. C. 1978. Increased growth of released white oak poles continues through two decades. J. For. 76: 726-727.

Schuler, T. M., and Fajvan, M. A. 1999. Understory tree characteristics and disturbance history of a central Appalachian forest prior to old-growth harvesting. USDA For. Ser. Res. Pap. NE710.

Singer, M. T., and Lorimer, C. G. 1997. Crown release as a potential old-growth restoration approach in northern hardwoods. Can. J. For. Res. 27: 1222-1232.

Smith, H. C., and Miller, G. W. 1991. Releasing 75- to 80-year old Appalachian hardwood sawtimber trees: 5-year D.B.H. response. In McCormick, L. H, and Gottschalk, K. W, eds. Proceedings, $8^{\text {th }}$ Central Hardwood Forest Conference. USDA For. Ser. Gen. Tech. Rep. NE148.

Sprugel, D. G. 1985. Natural disturbance and ecosystem energetics. . In Pickett, S. T. A., and White, P. S., eds. The ecology of natural disturbance and patch dynamics. Academic Press, San Diego, CA. pp. 335-352.

Stokes, M. A., and Smiley, T. L. 1968. An introduction to tree-ring dating. Univ. Arizona Press, Tuscon, AZ.

Sutherland, E. K. 1997. History of fire in a southern Ohio second-growth mixed-oak forest. In Pallardy, S. G., Cecich, R. A., Garrett, H. G., and Johnson, P. S., eds. Proceedings, $11^{\text {th }}$ Central Hardwood Forest Conference. USDA For. Ser. Gen. Tech. Rep. NC-188.

Tomlinson, P. T., Dickson, R. E., and Iebrands, J. G. 1991. Acropetal leaf differentiation in Quercus rubra (Fagaceae). Am. J. Bot. 78: 570-1575.

Trimble, G. R., Jr. 1960. Relative diameter growth rates of five upland oaks in West Virginia. J. For. 58: 111-115.

Trimble, G. R., Jr. 1968. Growth of Appalachian hardwoods as affected by site and residual stand density. USDA For. Ser. Res. Pap. NE-98.

Trimble, G. R., Jr. 1969. Diameter growth of individual hardwood trees. USDA For. Ser. Res. Pap. NE-145.

Trimble, G. R., and Tryon, E. H. 1966. Crown encroachment into openings cut in Appalachian hardwood stands. J. For. 66: 104-108.

USDA. 1959. Soil Survey of Preston County, West Virginia. USDA Soil Conservation Service, Washington, D. C. 
Vitousek, P. M. 1985. Community turnover and ecosystem nutrient dynamics. In Pickett, S. T. A., and White, P. S., eds. The ecology of natural disturbance and patch dynamics. Academic Press, San Diego, CA. pp. 325-332.

Ward, J. S. 1991. Growth response of upland oak sawtimber stands to thinning in Connecticut. North. J. App. For. 8: 104-107.

Waring, R. H. 1987. Characteristics of trees predisposed to die. BioScience 37: 569-574.

Yetter, T. C., and Runkle, J. R. 1986. Height growth rates of canopy tree species in southern Appalachian gaps. Castanea 51: 157-167. 
Table 3.1. Proportion of standardized tree-ring variation $\left(\mathrm{R}^{2}\right)$ that can be attributed to influence of 32 climatic variables (monthly precipitation and average monthly temperature, June-December of previous year, and January-September of current year), by species and crown release level.

\begin{tabular}{lcccc}
\hline Crown release level & chesnut oak & $\mathrm{n}$ & northern red oak & $\mathrm{n}$ \\
\hline & & & & \\
Control & $10.6 \%$ & 10 & $35.9 \%$ & 10 \\
$25 \%$ & $5.7 \%$ & 12 & $11.2 \%$ & 12 \\
$50 \%$ & $6.5 \%$ & 13 & $4.5 \%$ & 9 \\
$75 \%$ & $4.8 \%$ & 11 & $14.8 \%$ & 14 \\
$100 \%$ & $1.2 \%$ & 6 & $4.9 \%$ & 6 \\
\hline Average-all released & $4.5 \%$ & & $8.8 \%$ & \\
\hline
\end{tabular}

Table 3.2. Results of analysis of variance of $\%$ growth change (\%GC, dependent variable ) as a function of $\%$ crown release (\%CR), lag, and time interval (independent variables) using the General Linear Model Procedure (SAS Inst. Inst. Inc. 1998).

\section{Northern red oak}

\begin{tabular}{lcccc} 
Source & df & Mean Square & F & $p$ \\
\hline Lag (1-3 yr) & 2 & 8929 & 2.27 & 0.104 \\
Interval (7-15 yr) & 9 & 3832 & 0.97 & 0.461 \\
\%CR & 4 & 567310 & 145.60 & $<0.0001$ \\
Lag*Interval & 18 & 221 & 0.06 & 1.000
\end{tabular}

Chestnut oak

\begin{tabular}{lcccc} 
Source & df & Mean Square & F & p \\
\hline Lag $(1-3$ yr) & 2 & 7179 & 4.69 & 0.009 \\
Interval (7-15 yr) & 9 & 7840 & 5.12 & $<0.0001$ \\
\%CR & 4 & 411193 & 270.10 & $<0.0001$ \\
Lag*Interval & 18 & 8200 & 0.30 & 0.998
\end{tabular}


Table 3.3. Coefficients of the linear model: percent growth change $(\% \mathrm{GC})=$ $\mathrm{a}+\mathrm{b}^{*}$ percent crown release (\%CR), for lags of 1-3 years and averaging intervals of 7-12 years for northern red oak and chestnut oak.

\begin{tabular}{cccccc} 
& & \multicolumn{2}{c}{ Northern red oak } & \multicolumn{2}{c}{ Chestnut oak } \\
\hline Lag $($ yrs $)$ & Interval (yrs) & $\mathrm{b}$ & ${ }^{*} \mathrm{t}_{\text {coefficient }}$ & $\mathrm{b}$ & ${ }^{*} \mathrm{t}_{\text {coefficient }}$ \\
\hline 1 & 7 & 0.81 & 3.39 & 0.90 & 5.46 \\
1 & 8 & 0.85 & 3.41 & 0.90 & 5.77 \\
1 & 9 & 0.90 & 3.57 & 0.89 & 5.95 \\
1 & 10 & 0.95 & 3.62 & 0.92 & 6.07 \\
1 & 11 & 1.02 & 3.75 & 0.98 & 6.08 \\
1 & 12 & 1.03 & 3.89 & 0.95 & 6.25 \\
2 & 7 & 0.97 & 3.46 & 1.05 & 5.52 \\
2 & 8 & 0.98 & 3.49 & 0.99 & 5.72 \\
2 & 9 & 1.04 & 3.58 & 1.00 & 5.84 \\
2 & 10 & 1.09 & 3.70 & 1.04 & 5.91 \\
2 & 11 & 1.16 & 3.82 & 1.07 & 5.92 \\
2 & 12 & 1.16 & 3.91 & 1.03 & 6.13 \\
3 & 7 & 1.11 & 3.53 & 1.10 & 5.21 \\
3 & 8 & 1.13 & 3.49 & 1.07 & 5.29 \\
3 & 9 & 1.18 & 3.66 & 1.08 & 5.46 \\
3 & 10 & 1.20 & 3.78 & 1.09 & 5.57 \\
3 & 11 & 1.23 & 3.85 & 1.10 & 5.66 \\
3 & 12 & 1.21 & 3.95 & 1.02 & 5.84 \\
\hline
\end{tabular}

$* \mathrm{t}_{\text {coefficient }}$ greater than 2.714 are significant at the 0.05 level. 
Figure 3.1 Response function of northern red oak. Variables are monthly precipitation and average monthly temperature for June-December of the previous year, and JanuarySeptember of the current year. Months marked with an asterisk are significant at , $p<0.05$. Error bars indicate a $95 \%$ confidence interval.
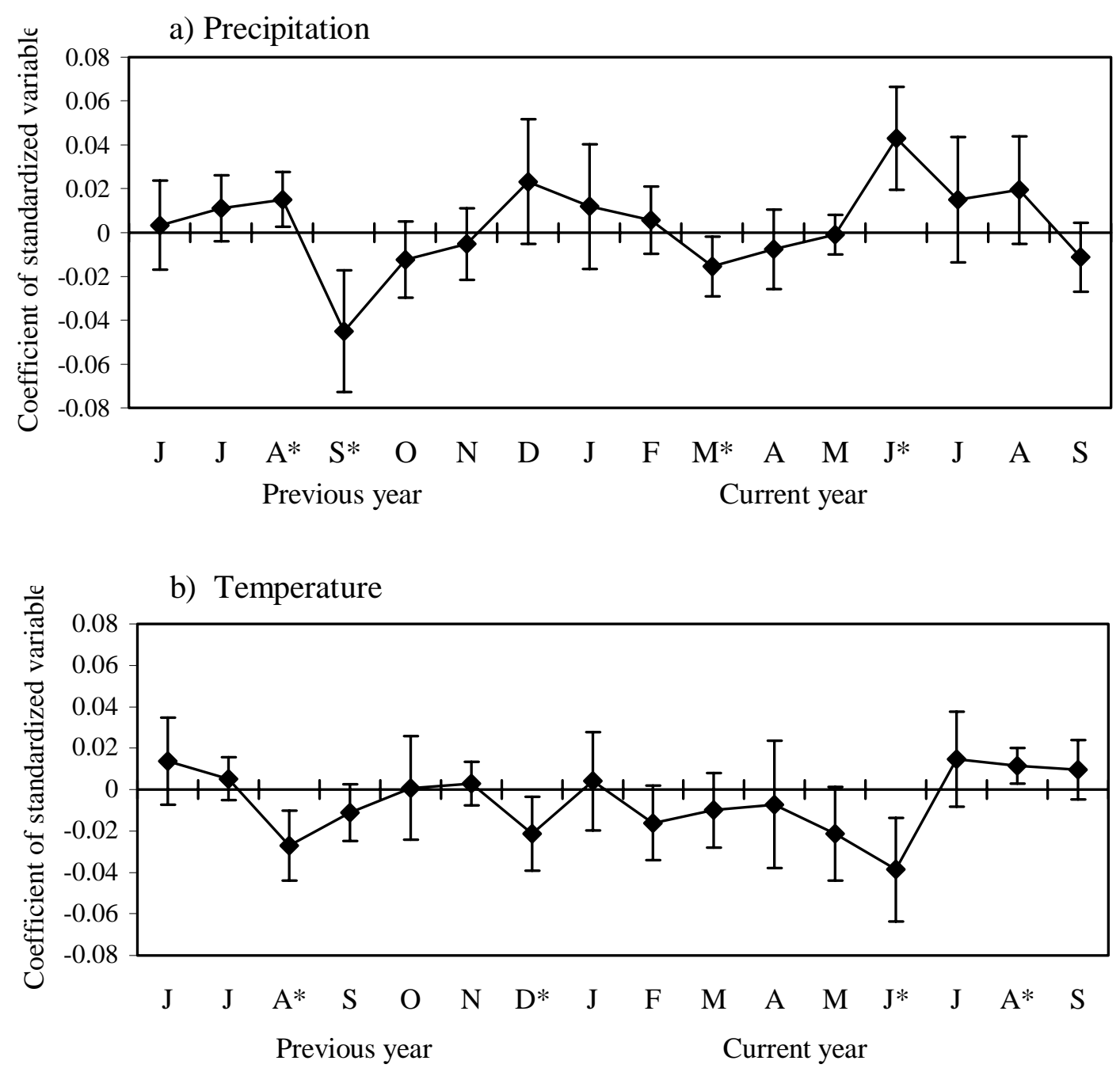
Figure 3.2 Response function of chestnut oak. Variables are monthly precipitation and average monthly temperature for June-December of the previous year, and JanuarySeptember of the current year. Months marked with an asterisk are significant at , $<0.05$. Error bars indicate a $95 \%$ confidence interval.
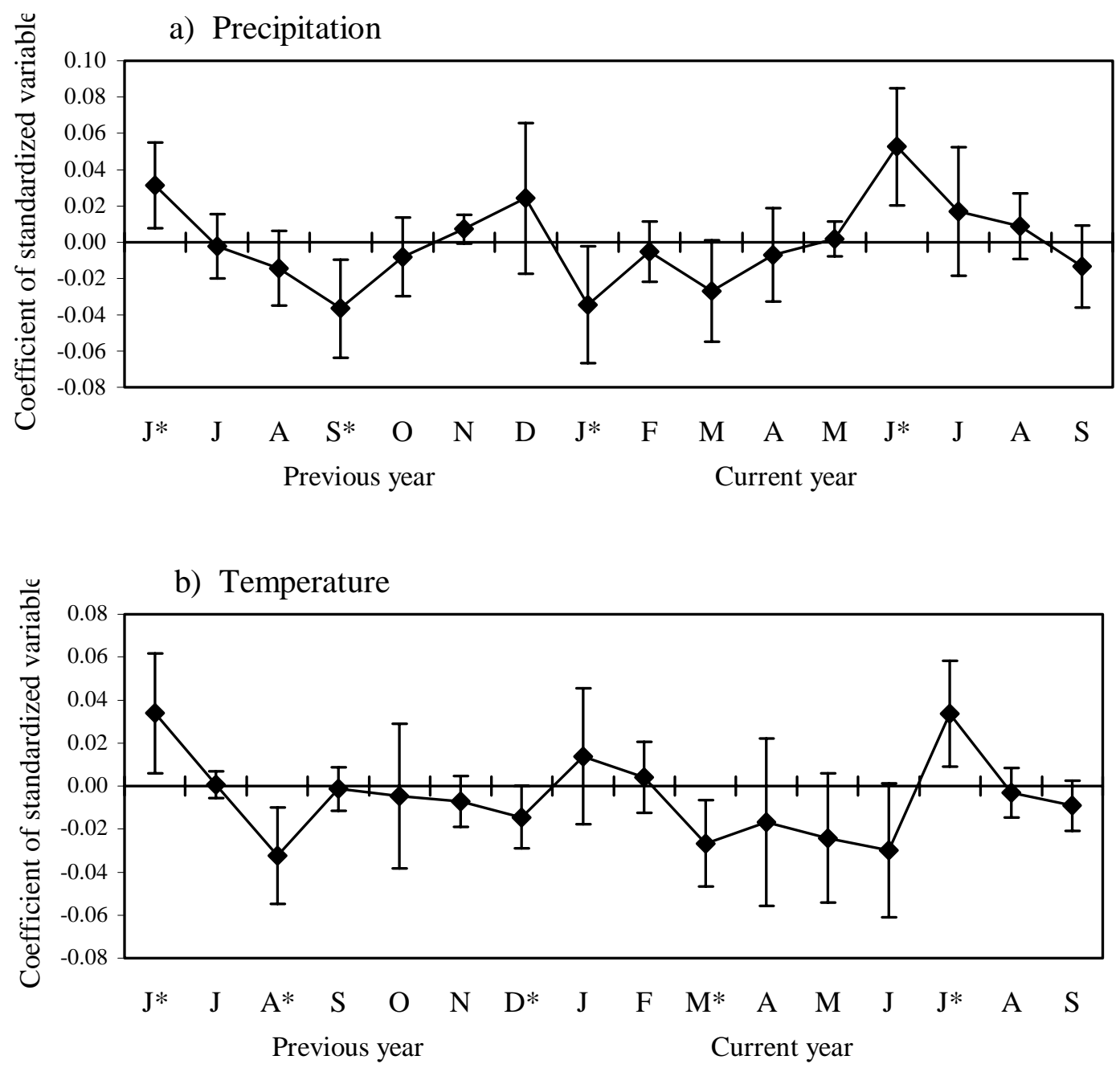
Figure 3.3. Average ring-width (a) and percent growth change (\%GC, b) for five levels of crown release for northern red oak, 1970-1990. Disturbance year is 1982 .

a) Average ring-width ( $\mathrm{mm})$

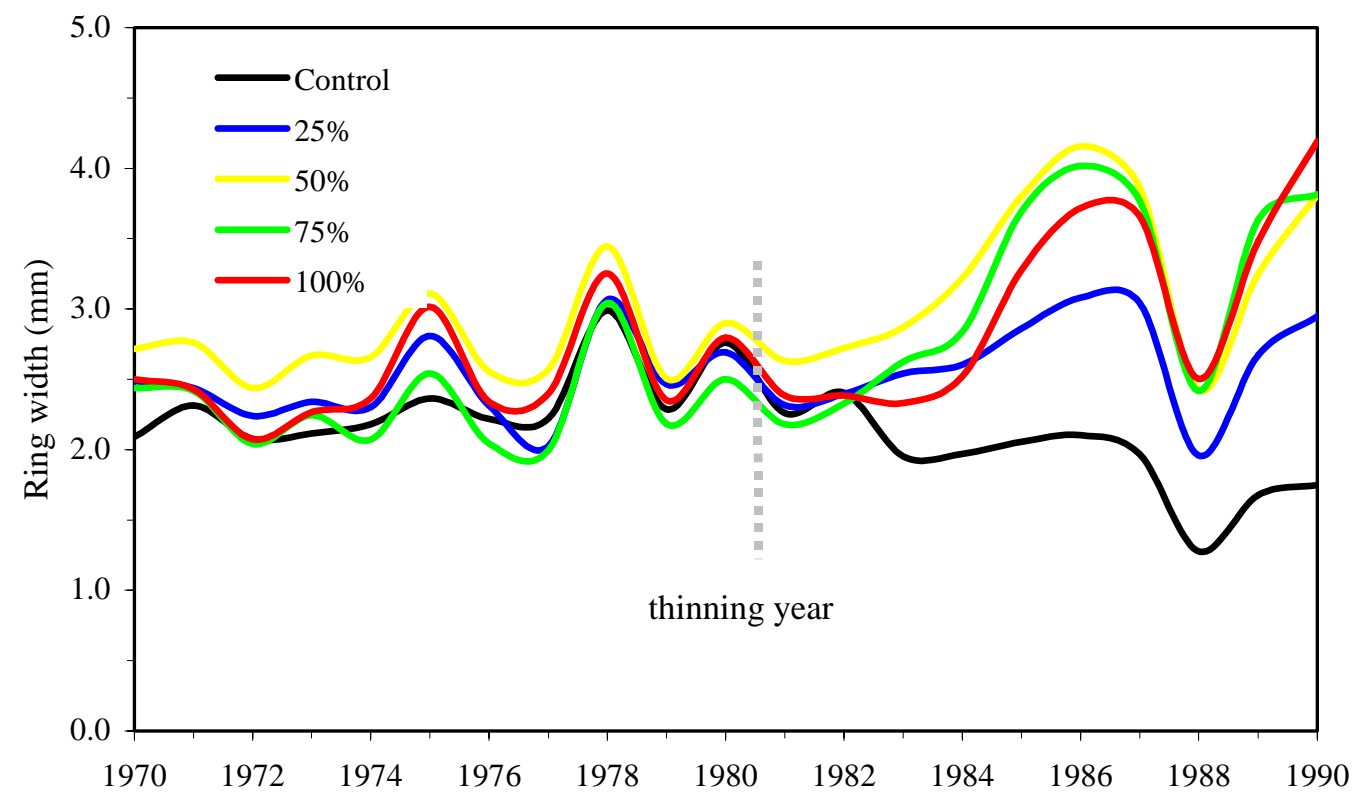

b) Percent growth change (\%GC), using a 10-yr interval and a 1-yr lag

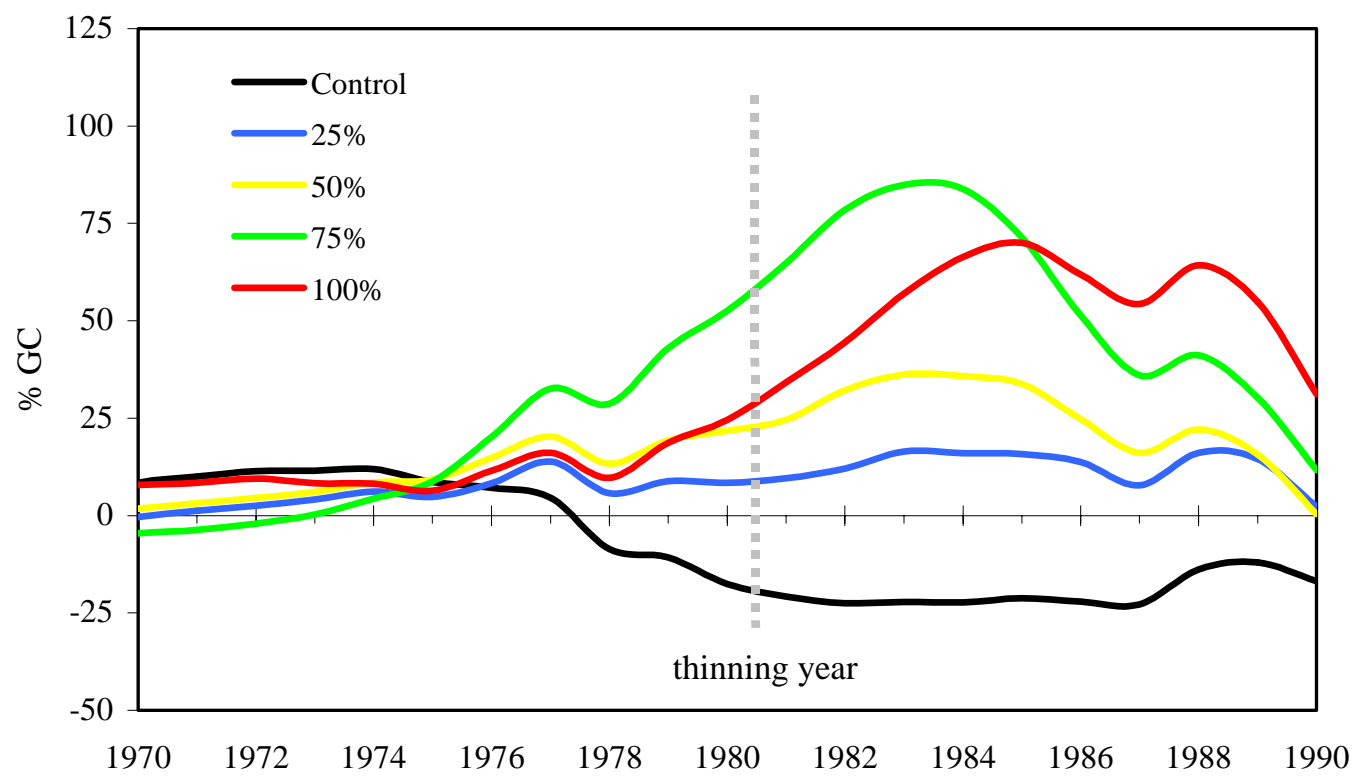


Figure 3.4. Average ring-width (a), and percent growth-change (\%GC, b) for five levels of crown release for chestnut oak, 1970-1990. Disturbance year is 1982 .

a) Average ring-width (mm)

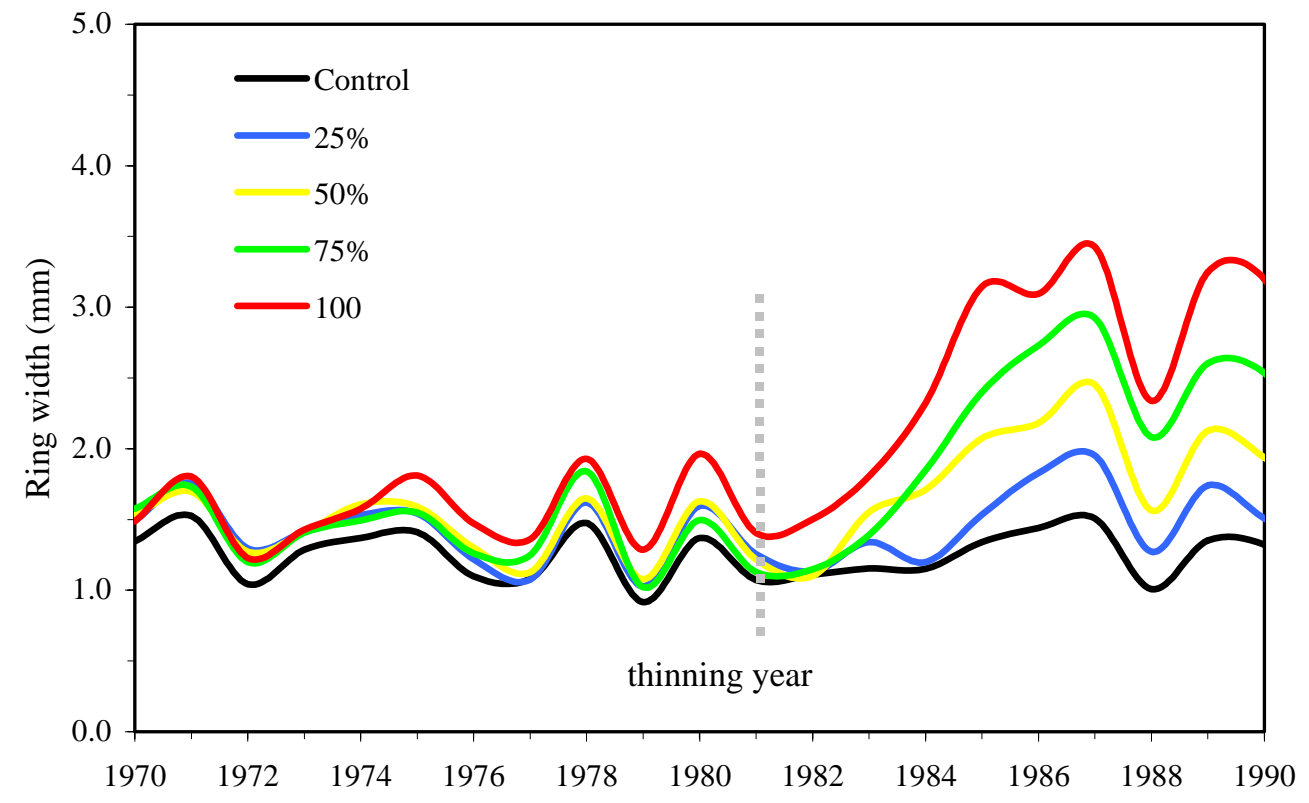

b) Percent growth change (\%GC) using a 7 yr interval and a 3 yr lag.

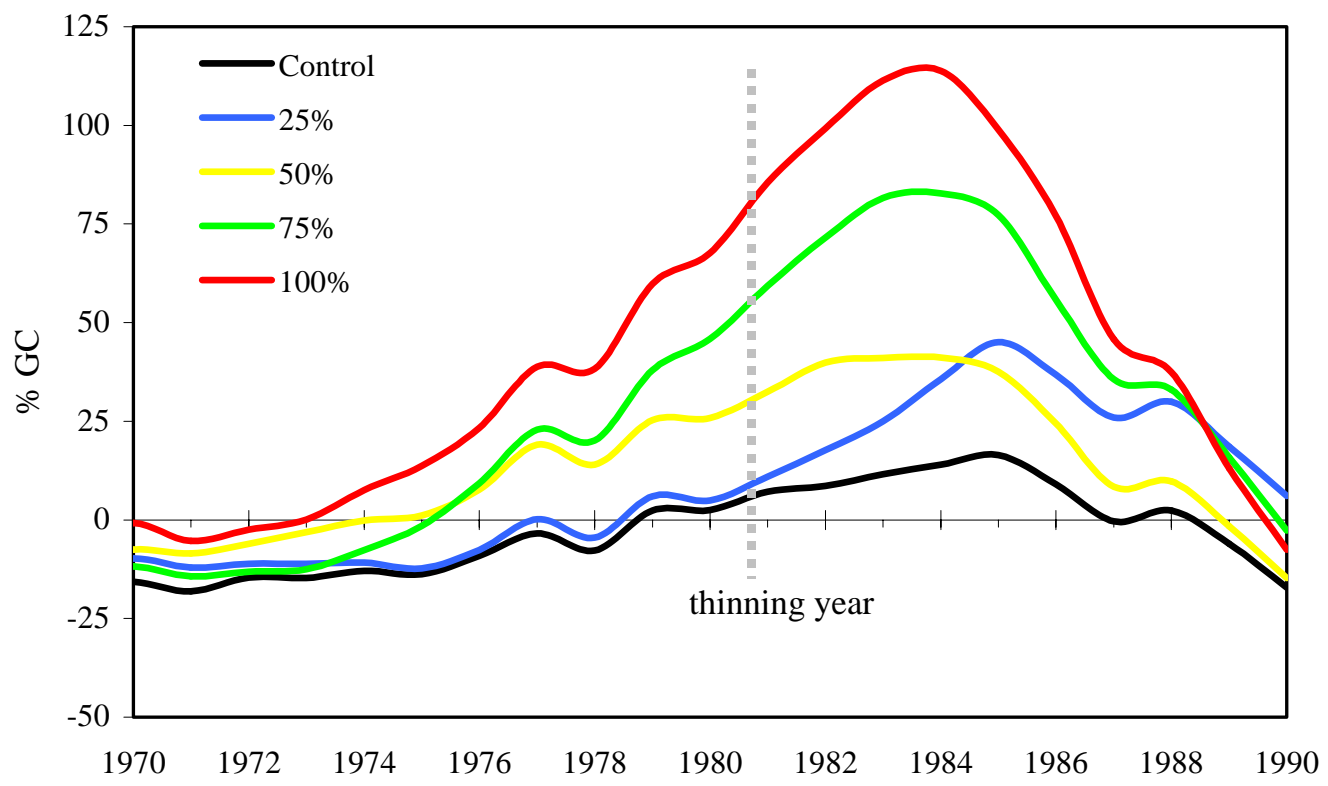




\title{
CHAPTER 4
}

\section{STAND COMPOSITION, STRUCTURE, AND DYNAMICS}

\begin{abstract}
Study plots (0.45 ha) were inventoried at five oak-dominated, old-growth stands in eastern Ohio, southwestern Pennsylvania, and central West Virginia. At two sites, the oak (Quercus spp.) component was limited to a few very large, dominant trees, and the importance values (IV's) of overstory sugar maple (Acer saccharum), red maple (A. rubrum), and American beech (Fagus grandifolia) equaled or exceeded those for oaks. At these sites, the oldest oaks were recruited around 1650, and oak recruitment ceased 1850-1875. At the remaining three sites, the oak component was more dominant, numerous, and distributed among more species, size- and age-classes, and oak establishment was more or less continuous through the early 1900s. In contrast, understory oaks (sapling and pole-sized trees, $2.5 \mathrm{~cm}>\mathrm{dbh}<15 \mathrm{~cm}$ ) were virtually absent from the understory strata at all five sites. Sugar maple and red maple were consistently the most abundant species in the advance regeneration plots, averaging 18,000 stems $\mathrm{ha}^{-1}$. Oak regeneration was present at most plots, but large oak seedlings ( $>1 \mathrm{~m}$ tall) were noted

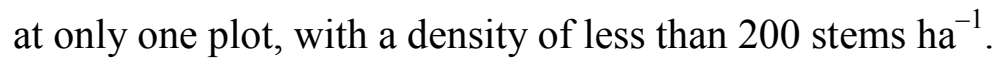

The rotated sigmoid curve provided a significantly better fit of diameter distributions of trees than did the reverse J-shaped curve. This curve reflects the variable rates of growth of stands composed of species with different life history strategies and ages. At all five sites, the oldest trees were oaks, and virtually no non-oak species were found in the older (e.g. $200 \mathrm{yr}$ ) cohorts. The oldest oaks at three sites date to well-defined time periods that suggest these stands
\end{abstract}


initiated in the aftermath of stand-initiating disturbances. Following stand initiation, there was an extended pause in tree-recruitment consistent with the stem exclusion and understory reinitiation stages of stand development. At the remaining two sites, the absence of clearly defined cohorts among the oldest trees and a pause in recruitment preclude a reliable estimate of stand origin, but these characteristics are consistent with the age structure of stands that have been uneven-aged for centuries. 


\section{Introduction}

In the first half of the $20^{\text {th }}$ century, Clements' (1916) views on succession dominated ecological thinking. He proposed that ecoystems progressed steadily and predictably along welldefined successional pathways to a stable, self-replicating state (the climax), that was the normal condition for a region and climate. The fact that most of the inhabited earth was covered by nonclimax ecosystems was attributed to the influence of humans, and considered unnatural and temporary (Sprugel 1991). Beginning in the 1970s, a number of research papers countered that natural disturbances are normal and recurring features of ecosystems. Further, it became clear that disturbances in some ecosystems were so common that the climax, or equilibrium state was rarely reached (Loucks 1970; Heinselman 1971; Bormann and Likens 1979). Additional research incorporated disturbance into the notion of ecosystem stability, and showed that some systems with a high incidence of disturbance could still be stable if the creation of new patches was balanced by the maturation of old ones_- "shifting mosaic steady state" (Bormann and Likens 1979). Today, few ecologists question the influence of disturbances on stand composition and structure. In fact, many texts have replaced the term "succession" with stand dynamics and stand development (Pickett and McDonnell 1989; Oliver and Larson 1996; Waring and Running 1998).

The fundamental link between disturbance, stand structure, and stand composition lies in fact that disturbances result in tree death, and the death of one tree releases growing space for others. In fact, it is the release of growing space, rather than the disturbance itself, which drives stand dynamics (Oliver and Larson 1996). On a structural level, a disturbance initiates a process of stand development whose starting point is dependent on the severity of the disturbance. For 
larger disturbances, Oliver and Larson (1996), Peet and Christiansen (1987), and Bormann and Likens (1979) delineated four stages of forest development based on structure, population dynamics, and biomass accumulation, respectively. A three phase model—gap, building, and mature - was proposed for gap process involving the death of a single canopy individual or a small group of trees (Whitmore 1989). The smallest gaps present the fewest opportunities, and are filled by crown extension of bordering overstory trees (Oliver and Stephens 1977; Runkle 1982, 1990). Larger gaps release existing saplings and pole-sized trees from overstory suppression. For these openings, the eventual success of the gap filler may be less dependent on gap size than the probability of an additional disturbance occurring (Runkle 1985; Canham 1989). The largest gaps have the greatest environmental heterogeneity, and provide the widest variety of niches for different species with different sizes (Runkle 1982; Canham et al. 1994); newly germinated seedlings, advance regeneration, and larger survivors are all potential gap fillers. In the largest gaps, the complete process of stand development is easiest to identify, but even in the smallest openings, stand development occurs as gaps are gradually filled either from above or below. The importance of time should not be underestimated. Forests are not just a Swiss cheese of holes and "non-holes," gaps and non-gaps (Lieberman et al. 1989). As the process of gap formation and closure occurs over an extended period of time, the structure of an all-aged forest begins to resemble a mosaic of canopy gaps in various stages of recovery (Bormann and Likens 1979; Lorimer 1985).

Disturbances initiate the process of stand development, but the two may be related in other ways. A stand may become more susceptible to disturbance as it grows and ages, so that the magnitude of disturbance - the threshold — required to kill trees becomes less than when stands were younger and smaller (Oliver and Larson 1996). Stands in the stem exclusion stage 
are much less vulnerable to windthrow than older stands with larger crowned trees and uneven canopy heights. One disturbance may increase or decrease the likelihood of another. A blowdown may provide fuel for surface fire, or by removing the oldest, tallest and most susceptible individuals, reduce the subsequent frequency of blowdown (Lorimer 1989).

Natural disturbances also signal potential changes in species composition. They are simultaneously a source of mortality for some individuals and a source of establishment and growth for others (Denslow 1980), and plant species are found where their life history strategies are compatible with the prevailing disturbance regime (Grime 1977; Denslow 1985; Runkle 1990) and patch size (Denslow 1980). In general, disturbances initiate, or renew, a process of species replacement that is dependent on the species present, their competitive potential and growth strategies, and the amount of growing space released by the disturbance.

A number of classification systems have been devised to link disturbance and species composition. Most classifications rely on a consideration of population dynamics, especially competition, regeneration, and mortality (Noble and Slatyr 1980), and physiology and life history strategies (Bazazz 1979). The JABOWA model (Botkin 1981) simulates plant response to disturbance based on resource availability and life history characteristics. Bormann and Likens (1979) delineated species by their ecological role and growth strategy (Hicks 1998). Grime (1977) distinguished between ruderal, competitive, and stress-tolerant strategies. Oaks do not fit well into standard ideas of succession, and are not readily characterized by their disturbance regime (Runkle 1990). Even though oaks are generally classified as midsuccessional species of intermediate shade tolerance (Burns and Honkala 1990), there is compelling evidence that oaks dominated many eastern presettlement forests (Sears 1925; Russell 1983; Abrams 1992; Bonnicksen 2000). The oak-hickory forest was considered climax 
by Braun (1950), and there is little indication in the early literature of conversion of oak forests to other species, even when logged by early settlers (Lorimer et al. 1994). Dominance of eastern upland forests in the oak-chestnut region by species more shade tolerant than oak was uncommon outside the more mesic and protected environments (Abrams and Downs 1990; Nowacki and Abrams 1992)

This chapter examines the composition and structure of five oak-dominated old-growth stands in three states in the central hardwood forest region. Two hypotheses are the basis for this analysis. First, the current structure of a stand may be linked to the disturbance(s) that initially created it and modified it throughout its history. The converse is also true. An absence of disturbance will also be reflected in structure. Second, the species that inhabit a stand are those whose life history strategies — modes of establishment, growth, and reproduction —are compatible with the prevailing disturbance regime (Grime 1977; Denslow 1980, 1985; Runkle 1990). Because this chapter focuses on current composition and structure, it represents a momentary snapshot of the outcome of 300 years of disturbance. However, even a snapshot suggests something about both the past and the future. For example, the size structure of a stand is an indication of relative rates of growth and tree movement from one size class to the next; the age structure reveals times of establishment and release that are invariably linked to disturbance and tree death. The presence of canopy gaps and coarse woody debris on the forest floor are certainly evidence of recent disturbance events. This chapter, however, concentrates on the outcomes of past disturbance. The dynamics of the disturbance regime will be the subject of the Chapter 5. 


\section{Study Area}

The study area occurs in that portion of the central hardwood region defined by Braun (1950) as the Mixed Mesophytic forest association. This is the unglaciated Appalachian Plateau physiographic province (Fenneman 1938), lying west of the northern hardwood and oak-pine forests of the Allegheny Mountain and Ridge and Valley physiographic provinces, respectively, and east of the Western Mesophytic forests of western Ohio, Indiana, and central Kentucky. Within this broad matrix, this study focuses on stands in which older oaks, either as a single species or as several species, make up a significant portion of the canopy.

In this study, I use old-growth as a stage of stand development, as defined by Oliver and Larson (1996). This model traces the developmental sequence following a major disturbance through four stages: stand initiation, stem exclusion, understory reinitiation, and old-growth. Transitional old-growth stands contain a few remnants of the initial even-aged cohort that were established after the last major, stand-wide disturbance. True old-growth occurs when all of the members of the initial disturbance-related cohort have died, and have been replaced by younger trees in a wide range of age-classes.

Old-growth deciduous forests in the eastern United States are relatively scarce. Davis (1996) found that only $0.4 \%$ of eastern forests could be classified as primary forest; Parker's (1989) conservative estimate for the central hardwood region was $0.07 \%$. The old-growth sites selected for this study are more strictly termed either a) stands, areas with distinct features (e.g., composition, topography, and age) that are part of larger, continuously forested tracts, or b) woodlots. The latter share many characteristics of stands, but are smaller and generally more disturbed. Farm woodlots are the most common example. Preliminary site selection criteria 
included the following: 1) the presence of large ( $\mathrm{dbh}>75 \mathrm{~cm}$ ), old (> $200 \mathrm{yr}$ ) oak trees; 2 ) the presence of at least three cohorts; 3) a minimum level of identifiable human disturbance (e.g., logging, grazing); 4) a minimum size of $\sim 4$ ha, large enough to hold two 0.45 ha study plots, and to maintain a buffer of at least $50 \mathrm{~m}$ from plot borders to the edge of the stand; and 5) a relatively homogenous stand composition that is dominated by deciduous trees with a strong oak component. Thus for example, mixed oak-conifer dominated stands were not considered. During preliminary surveys, increment cores from several of the larger oaks were extracted, and age-determinations were made to determine the presence of several age classes. Preliminary coring also confirmed whether there were sufficient numbers of non-hollow trees to make dendrochronological analysis feasible. Four sites in central West Virginia, two in Pennsylvania, and one in eastern Kentucky were examined and rejected. A total of five sites in eastern Ohio, southwestern Pennsylvania, and central West Virginia satisfied these criteria (Figure 4.1).

Collins Woods in Belmont County, Ohio, is a 7 ha stand located approximately three miles northwest of Morristown, in the region known as Egypt Valley $\left(40^{\circ} 05^{\prime} 57^{\prime \prime} \mathrm{N}, 81^{\circ} 11^{\prime} 19^{\prime \prime}\right.$ W). The first recorded European farm in this region of Ohio was established in 1788 (Caldwell 1880), and Morristown was established in 1801 (McKelvey 1903). When Kirkwood Township, which includes Collins Woods, was first surveyed between 1786 and 1806, only two farms were noted in surveyors' logs in the area $93 \mathrm{~km}^{2}\left(36 \mathrm{mi}^{2}\right)$ area. Collins Woods was purchased by the Ohio Nature Conservancy as an example of the presettlement forest of eastern Ohio, and is now managed by the Muskingham Watershed Conservancy District. Egypt Valley was extensively surface mined in the 1970's, and this site is distinguished by the presence of $15 \mathrm{~m}$ highwalls on the north and east borders, and a reclaimed slope to the west. The southern border consists of second growth hardwoods. 
The dominance of sugar maple (Acer saccharum Marsh) and American beech (Fagus grandifolia Ehrh.) at Collins Woods places these plots in the beech-sugar maple classification (SAF Type 60, Eyre 1980). Study plots occurred at an elevation of $340 \mathrm{~m}$ at an upper slope position, with a primarily west-northwest aspect. Slope inclination averaged $21 \%$. There were a few scattered stumps that suggest limited selective logging in the past.

Wrights Woods is an approximately 6 ha stand along Peters Creek in Washington County, Pennsylvania, near the town of Venetia ( $\left.40^{\circ} 14^{\prime} 40^{\prime \prime} \mathrm{N}, 80^{\circ} 01^{\prime} 52^{\prime \prime} \mathrm{W}\right)$. Wrights Woods is part of an original 320 ha $(800 \mathrm{ac})$ plat that was settled by Joshua and James Wright in 1765, when the region was in Yogogania County, Virginia. The land that contains Wrights Woods was conveyed to Wright's Chapel in 1823, and the site has been under the same ownership since then (Higbee 1999).

Iron making and charcoal hearths were prevalent in the mid 1800s, and underground coal mines permeate the area, including under the two study plots. Small, old excavations for house coal occurred at two locations adjacent to the study plots. On two sides, the study site is bordered by stands of second growth hardwoods. The north boundary is formed by Peters Creek, and an old surface mine borders the southern edge of the stand. Residents often use the woods for walking and hunting, and several ATV trails are present. At least two stumps were noted in the study site.

Sugar maple was the dominant single species in the two study plots, but together, white oak (Quercus alba L.) and northern red oak (Q. rubra L.) comprised the majority of stocking (SAF Type 52). The study plots occurred at an elevation of $320 \mathrm{~m}$. Slope position was lower slope, although topographic relief is minimal in the area. Slope aspect was primarily northnorthwest, and slope inclination averaged 20\%. 
Watter Smith State Park (Watter Smith) is the smallest of the five study sites, encompassing only approximately 5 ha. Watter Smith was the first European farmer to settle

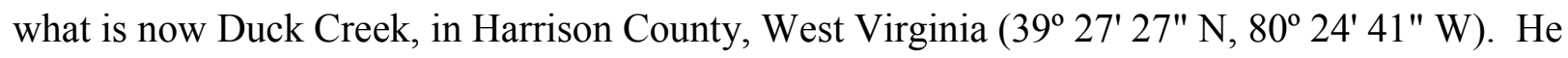
purchased the property in 1792 , settled it in 1796 , and the farm remained in the family until given to the State of West Virginia as an historical park in 1949.

The stand is very irregular in shape, lying along a deep ravine. It is bordered on two sides by second growth timber, and by a picnic area and paved road. A hiking trail passes through the study plot. Until 1949, the property had always been a farm, and doubtless the woods were open to cattle or pigs. American chestnut seedlings and two chestnut stumps were observed in the stand, although no recent evidence of tree cutting was apparent. Although park regulations forbid cutting of timber, snags have been cut (but not removed) when they present a hazard to hikers.

This was the most diverse site studied, with over 15 overstory tree species, including four oak species, two maples, and three hickories. The diverse terrain meant that in the ravines, buckeye (Aesculus octandra Marsh) and yellow-poplar (Liriodendron tulipifera L.) occurred, while chestnut oak and red maple were found at upper slope positions. Oaks comprised the majority of plot basal area, thus the northern red oak-white oak-black oak classification (SAF Type 52) best characterizes the cover type. The elevation of the study plot was $340 \mathrm{~m}$, at a midslope position. Because of the ravine, aspect was variable, but primarily southwest. The average slope inclination was $35 \%$.

Horners Woods (HW) is a 10 ha old growth tract near the West Fork River in Lewis County, near Roanoke, West Virginia ( $\left.38^{\circ} 58^{\prime} 08^{\prime \prime} \mathrm{N}, 80^{\circ} 28^{\prime} 47^{\prime \prime} \mathrm{W}\right)$. Earliest recorded ownership of the property was by Erasmus Rhodes in 1859. His daughter bequeathed the 
property to her son Roy Horner, who in 1936 gave the property to the State of West Virginia as a game refuge. The 1936 will described the property as "more than $1 / 2$ in woodland, much of which is original forest" (Will Book G, pp. 83-84, Lewis County Clerk's office). The will also stipulated that "the woodland be preserved and no timber cut therefrom, except such as may become dead or damaged." Horners Woods is now part of a 7400 ha wildlife management area, managed by the West Virginia Division of Natural Resources.

Europeans first arrived in the northwest section of Lewis County in 1769, but the area was settled slowly (Smith 1920). By 1779, there was one occupied dwelling in the county, and only 45 in 1785 (Gilchrist and Gilchrist 1993). Roanoke, the town closest to the study site, was settled in 1797. Kern (1980) reported a saw mill on the West Fork River in Roanoke in 1830. The area is primarily agricultural, although extractive industries, primarily natural gas, and to a lesser extent, coal mining, have been important. A multi-county area, which includes Lewis County, was a major exporter of beef cattle in 1920s, and much of the countryside was converted to pasture and corn.

There were no signs of timber harvest in this study site. The only known human disturbance occurred in the 1990s when a natural gas company constructed a road through one part of the old-growth stand. The road isolated an old-growth chestnut oak (Quercus prinus L.) stand on the ridge from the comparably aged white oak stand at midslope, that contained the study plots.

White oak and black oak (Quercus velutina Lam.) comprised half the plot basal area at Horners Woods (SAF Type 52). The study plots are bordered by 100-150 year old second growth forests on three sides, and is the boundary between the two forests is virtually 
indistinguishable. Study plots occurred at an elevation of $400 \mathrm{~m}$, with an average inclination of $36 \%$. The aspect was generally northwest facing.

The Murphy Tract is a 22 ha mixed-oak stand which contains the oldest trees found in this study. One white oak was dated to 1589. The stand lies along Brunnel Run in Ritchie County, West Virginia, three miles south of the town of Pennsboro (41 $14^{\circ} 41^{\prime \prime}$ N, $81^{\circ} 00^{\prime} 39^{\prime \prime}$ W). The first European explorers came from the West Fork River (Harrison County) in 1772, but of the five study areas, the region containing Murphy Tract was settled latest. Pennsboro was not established until 1801, and the Northwestern Turnpike between Clarksburg and Parkersburg (US 50) was not completed until 1836. During construction of the B\&O railroad through Ritchie County in 1857, a large railroad tie industry developed in the county (Brooks 1910).

This study area is part of a 110 ha preserve owned by the West Virginia Nature Conservancy. Most of the tract is second growth hardwoods. An area along the ridge immediately above the study plots appears to be an old field now in pole-sized hickory. There was no evidence of cutting in the study area, although a natural gas pipeline right-of-way bisects the old-growth stand.

White oak, red oak, and black oak shared dominance at Murphy Tract, placing this site in SAF cover type 52 (white oak-black oak-northern red oak). The two study plots occurred on a bench at an upperslope position, at an elevation of $305 \mathrm{~m}$. The plots were west-facing, with an average slope inclination of $23 \%$.

Climate, soils, and geologic summary. According to Bailey's (1995) classification of ecoregions of the United States, the study sites fall in the eastern forest (oceanic) province (221) of the Hot Continental Division, characterized by cold winters and warm summers, deeply dissected landforms, and winter deciduous vegetation. Precipitation averages $106 \mathrm{~cm} \mathrm{yr}^{-1}$, and is 
evenly distributed throughout the year. Winters are only slightly colder and summers cooler at the most northern (Collins Woods) site, although the growing seasons for Collins Woods and Horners Woods (the southernmost site) differ by 20 days. Bedrock under the study sites consists of sedimentary siltstones, shales, and sandstones, all of Pennsylvanian origin. Soils are generally Typic Hapludalfs, acidic, fine-loamy, mixed and well-drained soils of uplands, that are best suited for trees.

\section{Field Methods}

Study plots. Two $60 \times 75 \mathrm{~m}$ (0.45 ha) study plots were established at each study site, with the exception of Watter Smith, where only a single plot was established. The $60 \mathrm{~m}$ side of the plots was generally oriented down-slope. Within sites, study plots were intended to be replicates of each other, and thus had similar species composition, slope, aspect, and slopeposition. Study plots were no greater than $100 \mathrm{~m}$ apart. Each 0.45 ha study plot was divided into $2015 \times 15$ m subplots, and temporarily marked by flags and $150 \mathrm{~m}$ tapes. Aspect, percent slope, and slope-position for each subplot were recorded. All potential overstory stems $\geq 2.5 \mathrm{~cm} \mathrm{dbh}$ were measured and mapped on a grid. Maps showing tree locations and, in particular, cored tree locations, were prepared using grid coordinates. Potential overstory trees were classified as either overstory (dominant, codominant, or intermediate), or understory (overtopped), based on the amount of sunlight available to the crown (Oliver and Larson 1996). Overstory trees were defined as trees with a $\mathrm{dbh} \geq 15 \mathrm{~cm}$. For these trees, total height was estimated using a clinometer. Crown size, defined by crown borders with adjacent trees, was measured along two perpendicular axes, and calculated using the formula for the area of a circle. The vigor of each 
canopy tree was estimated, using a USDA Forest Service vigor code ranking system where $1=$ healthy with no signs of crown dieback, and $7=$ standing dead.

In each $15 \times 15 \mathrm{~m}$ subplot, two $2 \times 2 \mathrm{~m}$ regeneration plots were established (total $160 \mathrm{~m}^{2}$ plot $\left.^{-1}\right)$. Stems of potential canopy trees were tallied as either small $(<1 \mathrm{~m}$ tall), or large $(\geq 1 \mathrm{~m}$ tall, $<2.5 \mathrm{~cm} \mathrm{dbh).} \mathrm{At} \mathrm{Collins} \mathrm{Woods,} \mathrm{regeneration} \mathrm{data} \mathrm{represents} \mathrm{data} \mathrm{reported} \mathrm{in} \mathrm{a} \mathrm{recent}$ survey by Hicks (1998). Evidence of browse and deer scat in the regeneration plots was also noted as either present or absent.

Coarse woody debris (CWD) with a minimum diameter of $15 \mathrm{~cm}$ at the smaller end was also identified to species (when possible) and mapped within each subplot. Snags were measured at dbh, and total height recorded. Diameters of small and large ends of downed logs and large branch fragments were measured, as well as the total length within the subplot. Downed logs were classed as either snaps or tipovers based on the presence of exposed root balls or root pits and mounds, and the direction of fall was measured with a compass.

Increment coring. In each $15 \times 15 \mathrm{~m}$ subplot, the largest diameter tree was cored. In most cases, the second-largest tree was also cored, particularly if it was an oak $(n=307)$. Two cores were extracted at breast height $(1.4 \mathrm{~m})$, stored in plastic straws, and labeled. Coring heights were occasionally slightly greater for trees with butt swell at breast height, often the case with large red oaks. Up- and down-slope locations on the bole were avoided in order to capture the same tree-ring chronology, and because of exaggerated ring widths due to tension wood, although sometimes these were the only suitable bole faces where coring was feasible.

The aim of coring the largest diameter canopy tree was to capture the variation of radial growth over the longest time period possible in each $15 \times 15 \mathrm{~m}$ subplot, with the implicit assumption that trees with the largest dbh and crown areas are generally oldest. Cored trees 
represented an average of $63 \%$ of the plot basal area, and $68 \%$ of the total crown area (Tab. 4.1). Oaks comprised the largest portion of cored trees $(n=173)$, representing an average of $44 \%$ and $39 \%$ of the total plot basal area and crown area, respectively. Cores were considered suitable if they terminated at least $2 \mathrm{~cm}$ from the pith. When internal rot was encountered, at least two additional attempts were made at different bole locations to reach the pith. Cores from 31 trees were discarded from the age analysis due to internal rot, and because of partial rot, 15 trees were represented by one core.

Canopy gaps. Three criteria were used to identify canopy gaps. First, only gaps that were formed by the death of a whole canopy tree were considered (Romme and Martin 1982). This was indicated by the presence of a standing snag or downed log in the gap; cases where partial top-breakage resulted in small gaps (even if they met criteria number 2) were not considered. Second, the minimum gap size considered was $25 \mathrm{~m}^{2}$, based of a range of $27-40 \mathrm{~m}^{2}$ crown size for intermediate-class canopy trees (the smallest tree that may create a canopy gap), and gap size distributions reported by Runkle (1990) and Busing and White (1997). Third, gap age placed a limit on those gaps that could be sampled. Gaps that are old and partially closed have canopies are often distinguishable from the canopy of surrounding border trees (Runkle 1992). Thus, only gaps $\sim$ ten years old or less were considered (Runkle 1982, Cho and Berner 1991).

The dimensions of canopy gaps that met these three criteria were measured along their two perpendicular axes. Actual gap area, whose borders are defined by the edge of the surrounding canopy (Runkle 1982), was calculated using the formula for an ellipse.

$$
\text { Crown area }\left(\mathrm{m}^{2}\right)=\left(\text { Diameter }_{1} \times \text { Diameter }_{2}\right) / 4 \times \pi
$$


When a gap occurred along the plot border, only that portion that fell within the 0.45 ha study plot was considered. Gap makers, the largest downed tree or snag in the gap, and probable gap fillers, the largest potential canopy sapling(s) growing in the high light area, were identified and measured. The agents of gap formation (e. g., windthrow, soil slippage, top-breakage due to glaze, snags) were estimated, and the orientation of each downed log was recorded. In each gap, a $2 \mathrm{~m}$ wide regeneration belt was tallied along the long axis through the center of the gap, using the same methodology as in the canopy understory plots. The probable gap filler and at least one border tree were also cored in order to estimate the year of disturbance.

\section{Laboratory and Analytic Methods}

Species composition. As a general means of comparing species composition between sites, importance values (IV) were calculated for each species. For both overstory ( $\mathrm{dbh} \geq 15 \mathrm{~cm}$ ) and understory $(2.5 \mathrm{~cm} \leq \mathrm{dbh}<15 \mathrm{~cm})$ stems, IV was defined as the average of the species' relative basal area, relative abundance, and relative frequency $($ maximum $=100)$ :

$$
\text { Species IV }=(\mathrm{RBA}+\mathrm{RA}+\mathrm{RF}) / 3
$$

I used cluster analysis to classify the nine overstory plots by species similarity, and detrended correspondance analysis (DCA) to ordinate the combined overstory and understory composition. In both cases, data were input as species IV. Cluster analysis is an agglomerative method of numerical classification that groups points (plots) with similar characteristics in mathematical space (Kent and Coker 1995). The technique starts with individual plots and combines them progressively until all the plots are in one group. I used the Euclidean distance as the distance measure between plots, and Ward's method of linkage, a technique based on 
minimizing the in-cluster variance. As much as possible, plots within sites were intended to be replicates of each other in terms of site conditions and species composition. This technique provides a good method of assessing within-study site similarity, as well as the overall structure of the nine plots.

Detrended correspondance analysis is indirect gradient analysis, one of several multivariate techniques that arrange sites along axes on the basis of their species composition. The technique assigns each site a set of coordinates in two-dimensional space according to the weighted scores of its constituent species (Kent and Coker 1995). I used DCA to examine how closely the sapling strata (the future forest) resembled the existing canopy. Using species IV's as input values, I merged the overstory and understory data. I also used the combined data set of understory tree IV, understory regeneration, and gap regeneration in the same manner. DCA is most often used to uncover the underlying structure of stands along spatial or environmental gradients (Jongman et al. 1995). Here, a temporal gradient is introduced by comparing existing and future canopy composition, and understory and gap regeneration. Both cluster analysis and DCA were performed using PC-ORD ${ }^{\circledR}$ software (McCune and Mefford 1997).

Diameter structure. The diameter distribution of uneven-aged, unmanaged forests has often been described by the negative exponential, or reverse J-shaped curve (Nyland 1996; Smith et al. 1997). In this model, the shape of the curve is determined by the factor $q$, a ratio of the numbers of trees in one diameter class to the next larger class. The $q$ factor is, in essence, a probability function, an expression of the percentage of trees that survive to grow from one dbh class to the next larger one. Diameter distributions for each study plot were prepared by summing the number of live stems in each $5 \mathrm{~cm}$ diameter class (i.e., $2.5-7.4 \mathrm{~cm}, 7.5-12.4$ $\mathrm{cm} . .102 .5-107.5 \mathrm{~cm}$ ), and $q$ 's were calculated as the ratio of the density of consecutive dbh 
classes. For individual species distributions, I combined trees with similar silvical characteristics, for example, maples (sugar maple and red maple), hickories (pignut, mockernut, and bitternut hickory), white oak (white oak and chestnut oak), and red oak (northern red oak and black oak).

Age distribution. The age distribution at breast height for the cored canopy trees was prepared from increment cores. Cores were prepared using standard dendrochronological techniques (cf. Stokes and Smiley 1968). A master chronology was prepared for each site, and cores were cross-dated by comparing unique patterns of narrow and wide rings. Annual ring widths were then measured to the nearest $0.001 \mathrm{~mm}$ using a Leica Stereo Zoom-5 binocular microscope, an Acu-rite measuring stage, and a Quik-Chek 1000 digital readout, in conjunction with $\mathrm{J}_{2} \mathrm{X}^{\circledR}$ recording software. Ring dating was validated using the program COFECHA (Grissino-Mayer et al. 1997). COFECHA uses a correlation procedure that enhances the time series characteristics (wide and narrow ring patterns) to ensure proper calendar year assignment. Suitably cross-dated segments have, at minimum, a correlation coefficient of 0.3281 with the master chronology $(\mathrm{p}<0.01)$. Its default settings compare successive 50-year segments of each chronology, lagged by 25 years, and flag problem years for further review. Segments may be flagged for two reasons: 1) "A" flags are indicated when the correlation coefficient is less than 0.3281 , but highest as dated; and 2) "B" flags mean the segment may cross-date better at another position. In the latter case, problem segments were re-examined for missing or duplicated ring measurements, and the dating was adjusted until the flag was eliminated. In some cases, problems could not be resolved, if a) if no missing or extra rings were found, b) when better correlations required a shift of 5-10 years, or c) when adjustments of one segment caused additional problems in properly dated segments. Summary statistics from the COFECHA 
analysis are shown in Table 4.2. Once individual cores were properly dated, they were averaged to yield a mean chronology for each tree.

Only cores that terminated within $2 \mathrm{~cm}$ of the pith were used for aging trees. Additional years to the pith were estimated based on the amount of curvature of the innermost rings, and the average width of the earliest ten rings. The early 10 -year growth was estimated as either 1 $\mathrm{mm} / \mathrm{yr}$ or $3 \mathrm{~mm} / \mathrm{yr}$, and a maximum of 20 years added to estimate dbh age. The average number of years added across all sites was five years. Linear regression of age vs. diameter was used to date four chestnut oaks at Horners Woods, and seven white oaks at Murphy Tract that had internal rot.

In addition to determining establishment years, early growth patterns of cored trees were used to indicate whether the tree originated in partial shade of the overstory, or in a high light environment of a gap. Although this subject will be discussed in greater detail in Chapter 5, the following distinction between gap-origin and understory origin was used here: 1) growth patterns of trees that start out relatively high and remain flat, decline continuously, or have a slight upward arch in the early years followed by declining pattern are considered evidence that a tree was in a gap by the time it reached dbh (Lorimer et al. 1988; Lorimer and Frelich 1989; Frelich and Graumlich 1994). In contrast, a below-average juvenile growth rate followed by a significant and sustained growth increase (crown release) was considered evidence that the tree established in the shaded understory, and reached overstory position only after an adjacent canopy disturbance (Nowacki and Abrams 1997).

Coarse woody debris (CWD). The basal area of standing snags was calculated using dbh. Volumes of snaps and tips were calculated by species using Smalian's formula:

$$
\text { Volume }=\left(\text { basal area } a_{\text {top }}+\text { basal area } a_{\text {bottom }}\right) / 2 \times \text { length }
$$


The spatial distribution of CWD was estimated at $15 \mathrm{~m}, 30 \mathrm{~m}, 45 \mathrm{~m}$, and $60 \mathrm{~m}$ spatial scales for each 0.45 ha study plot using Morisita's Index of Dispersion $\left(\mathrm{I}_{\mathrm{d}}\right)$. . This index is derived from information theory, and compares the counts of individuals in successively larger quadrats (Goodall and West 1979):

$$
\mathrm{I}_{\mathrm{d}}=\mathrm{n} \times \frac{\left[\sum \mathrm{x}^{2}-\Sigma \mathrm{x}\right]}{\left[(\Sigma \mathrm{x})^{2}-\Sigma \mathrm{x}\right]}
$$

where $\mathrm{n}$ is the number of quadrats (sample size) and $\mathrm{x}$ is the count of CWD in each quadrat. I used volume $\left(\mathrm{m}^{3}\right)$ as the count when considering downed logs, and frequency for standing snags. The index is relatively independent of population density, and has the desirable statistical property of having a known, chi-square distribution (Krebs 1999). The expected value of $I_{d}$ for randomly distributed individuals is 1 . Values greater than 1 suggests a clumped pattern, while values less than unity suggest an even or regular distribution. The statistical significance of the index is determined from the chi-square distribution $(\alpha=0.05)$ :

$$
\chi_{\text {test }}^{2}=\mathrm{I}_{\mathrm{d}} \mathrm{x}(\Sigma \mathrm{x}-1)+\mathrm{n}-\Sigma \mathrm{x} \quad(\mathrm{df}=\mathrm{n}-1)
$$

The direction of fall of downed logs may also be a function of disturbance dynamics. Similarity of log orientation may suggest a large disturbance event affecting several trees, or single tree-events that correlate to the direction of prevailing winds. Conversely, a random distribution of orientations may suggest single-tree events resulting from endogenous causes. The frequency distribution of the direction of fall of downed logs versus aspect of each subplot was plotted. Because no statistical test of significance was available, the relevance of the results was determined by simple inspection of the graph. Finally, diameter distributions of dead and live trees were compared using the nonparametric Kolmogorov-Smirnov test.

Canopy gaps. Total area of the 0.45 ha study plot in canopy gaps was summed. Gap age, or the year of gap formation, was determined by the presence of a release event in the tree- 
ring chronologies of the gap fillers and/or boundary trees. Diameter distributions of gap makers, gap fillers, and boundary trees were prepared by species group (i.e., oaks, maples, hickories) for each 0.45 ha study plot, and compared to the distributions of live stems. Regeneration in the $2 \mathrm{~m}$ wide belt transect along the gap long axis was converted to a per hectare basis. These values, along with 0.45 ha regeneration values were then input to DCA to see the similarity between the existing understory and the future overstory.

Results

Species composition. By design, oaks occupied, at minimum, a codominant position in the overstory $(\mathrm{dbh} \geq 15 \mathrm{~cm})$ of all nine study plots. Oak IV ranged from a minimum of 13 at Collins Woods1, where sugar maple and American beech were more important, to 58 at Murphy Tract2 (Table 4.4). Cluster analysis confirmed that plots within sites linked at fairly low levels and were generally most similar to each other (Figure 4.2). It also revealed two distinct groupings. Collins Woods and Wrights Woods comprise one group. Here, the importance of oak was due to a relatively large basal area concentrated on a few, large individuals. For example, Collins Woods 1 had only 11 oaks ha $^{-1}$, but these trees represented $22 \%$ of the total plot basal area, and $12 \%$ of the total plot crown area (Table 4.3 ). In this group stocking, species richness, and species diversity, (Shannon-Weiner index, $\mathrm{H}^{\prime}$ ), for canopy-class size trees both tended to be low (averages, $190 \mathrm{tph}, \mathrm{N}=8, \mathrm{H}^{\prime}=1.6$, respectively). Conversely the relative importance of shade tolerant overstory species such as sugar maple (Wrights Woods), or sugar maple, red maple (Acer rubrum L.), and American beech (Collins Woods) was much higher. Among a second group of sites (Murphy Tract, Horners Woods, Watter Smith), the oak 
component was more dominant, numerous, and distributed among more species, size- and ageclasses. For example, five oaks species had a total IV of 58 at Murphy Tract (Table 4.4), and oaks represented $81 \%$ of the plot basal area, and $60 \%$ of the plot crown area.

When composition of the understory (overtopped trees, $2.5 \mathrm{~cm}<\mathrm{dbh}<15 \mathrm{~cm}$ ) was considered, the nine plots differentiate into similar groupings (Table 4.5). Shade tolerant species were dominant at all plots, but greatest at Collins Woods and Wrights Woods (average sugar maple IV $=76$ ). Species richness diversity in this stratum reflected the overstory dominance of sugar maple. Only 7-8 species made up the understory at Collins Woods and Wrights Woods, with an average $\mathrm{H}^{\prime}$ of 0.9 . Four of these species occurred only 1-2 times in a plot. In plots with a stronger oak component in the overstory, sugar maple and/or red maple were present in the understory, but other species tended to share a larger portion of total plot IV. For example, Watter Smith had the highest understory H' (2.1), with American beech, musclewood (Carpinus caroliniana Walt.), flowering dogwood (Cornus florida L.), and eastern hophornbeam (Ostrya virginiana [Mill] K. Koch) all making significant contributions. The nine study plots were similar in one respect. The combined IV of understory oaks was striking by its relative nonimportance. Oak saplings and pole-sized trees were absent in this stratum at five study plots, and only at Murphy Tract2 did the combined oak IV approach a value of 10 .

Species composition trends in the regeneration plots closely paralleled those of the understory tree stratum (Table 4.6). Although total seedling density and diversity varied considerably between study sites, sugar maple and red maple were consistently the most abundant species, averaging 18,000 stems ha ${ }^{-1}$. Most of these were in the small category $(<1 \mathrm{~m}$ tall), and of these the majority were $<10 \mathrm{~cm}$ tall. For example, Murphy Tract2 had 45,000 red maple seedlings ha ${ }^{-1}$, although only 313 were $>1 \mathrm{~m}$ tall. Sugar maple and American beech both 
averaged between 400-500 large seedlings ha ${ }^{-1}$. Oak regeneration was present at all plots but Collins Woods; however large oak seedlings were limited to the two Murphy Tract plots, and even there, their numbers were less than 200 stems $^{-1}{ }^{-1}$. Among the oaks, seedlings of more shade-tolerant species such as white oak (Quercus alba L.) and chestnut oak (Q. prinus L.) far outnumbered the red oaks. The impact of deer and/or other grazers was considerable at all five sites, but greatest at Wrights Woods, where $60 \%$ of the regeneration plots showed evidence of browse. On average, about half the regeneration plots showed signs of herbivory.

Ordination of the combined overstory-understory data set reinforces the dissimilarities between the oak-dominated overstories and the shade-tolerant understories, and suggests trends about the future composition of these forests (Figure 4.3). The plots clustered in three general groupings. Understory and overstory strata for Collins Woods and Wrights Woods, dominated in both cases by sugar maple, formed one cluster at the lower left. The understory strata of Horners Woods, Murphy Tract, and Watter Smith grouped at top-center, and were clearly separated from their more diverse, oak-dominated overstory strata at lower right.

Diameter structure. Figure 4.4 shows diameter distributions of all trees $(\mathrm{dbh} \geq 2.5 \mathrm{~cm})$ of the nine study plots. These curves are characterized by several hundred stems in the 5 and 10 cm diameter classes, and steadily declining numbers in larger size-classes. All plots had only 14 trees in the largest dbh classes. The distributions reveal an uneven pattern of: 1) a steady decrease in density with size in the smallest size classes, 2) a rise to a series of intermittent peaks in mid-sized classes, 3) a further decline of density of the largest trees, and 4) at some plots, an unexpectedly large number of trees in the largest size class.

Size distributions for individual species showed the following general trends: 1) maples (sugar maple, and to a smaller degree, red maple) dominated the smallest size classes, ranging 
from 613 stems ha $^{-1}$ (Collins Woods $1,85 \%$ of total) in the $5 \mathrm{~cm}$ dbh class to 140 stems ha $^{-1}$ (90\%, Wrights Woods1). Distribution curves for maples took two forms, depending on the relative importance of oaks and maples' position in the overstory. Where oaks were most dominant, curves for maple were consistently reverse J-shaped (Figure 4.5a). However where oaks were limited to a small number of trees in the largest dbh-classes (Collins Woods, Wrights Woods), maples showed a second peak in the 30-60 cm dbh classes, although at a much lower value (Figure 4.5b); 2) American beech was also abundant in the $5 \mathrm{~cm}$ size class, exceeding maple in Horners Woods2 and Watter Smith. This species also followed the same pattern as maple, depending on its overstory importance (Figures 4.5a-b); 3) hickories (Carya spp. L.) and black cherry (Prunus serotina Ehrh.) were numerous at several plots, occupying a codominant or intermediate position in the overstory. These species had a normal distribution that was usually skewed toward the smaller size classes for hickory, and toward larger size classes for black cherry, although they were never among the largest trees (Figure 4.5c); 4) although oaks were consistently the largest trees, they were virtually absent from the smallest size classes, and often showed large gaps in the distribution (Figure 4.5e). Gaps were largest at Wrights Woods, although this was in part due to the small number of trees in the sample. The more shade tolerant white oaks (white oak and chestnut oak) were mostly irregular in distribution (Figure 4.5e), although at Murphy Tract, the curves were bimodal, with peaks in the $20 \mathrm{~cm}$ and $65 \mathrm{~cm}$ size classes (Figure 4.5d). In contrast, red oaks (red oak and black oak) approximated a normal distribution, peaking between 50-65 $\mathrm{cm}$ dbh (Figure 4.5d-e).

To test how well the theoretical negative exponential or reverse J-shaped model fit the diameter distributions of these plots, I calculated $q$ values between successive size classes for each plot (Table 4.7). Only the two Murphy Tract plots approached the idealized model, with a 
more or less constant $q$ and a small range between the largest value and the smallest one. At the remaining plots, $q$ was quite variable, generally twice as high between the $5-10 \mathrm{~cm}$ classes as the next pair. At Collins Woods the standard deviation over all $q$ 's equaled or exceeded its mean. At all plots, $q$ reached a second peak in the $35-55 \mathrm{~cm}$ area of the curve, and a third peak generally occurred between the larger classes. Where oaks were limited to the largest size classes (Collins Woods and Wrights Woods), overstory maples and beech composed this second peak. At the remaining sites, a mixture of species, including oaks, hickories, cucumber tree (Magnolia acuminata L.), white ash (Fraxinus americana L.), as well as maples and beech shared abundance in this mid-range of diameters. The third peak was primarily oaks, but included yellow-poplar at Collins Woods1 and Horners Woods2, and American elm (Ulmus americana L.) at Collins Woods1.

A constant $q$ means in effect that the probability of a tree moving from one dbh class to the next is the same. The variability of $q$ suggests that growth and mortality are not constant in these plots; mortality is greater among smaller, understory trees (Harcombe 1987), and larger overstory dominants and codominants (Runkle 2000). Gough and West (1975) proposed a rotated sigmoid curve as a better expression of this type of distribution. This curve is distinguished by a plateau (nearly level or slightly negative slope) in the mid-dbh classes when the log of the number of trees is plotted over dbh class, and steeper curves in the small and large classes where mortality is greater. Figure 4.6 shows this model applied to the nine study plots. $\mathrm{R}^{2}$ for a $3^{\text {rd }}$ order polynomial regression ranged from 0.700 (Collins Woods1) to 0.920 (Murphy Tract2), and the rotated sigmoid distribution provided a better fit (i.e., $\mathrm{R}^{2}$ value) than the negative exponential model. The presence of empty dbh classes complicates curve fitting, particularly when the next successive class has more than the expected number of trees, as in 
Wrights Woods1-2. Because some plots had a larger than expected number of trees in the largest classes (an additional plateau), a $4^{\text {th }}$ or $5^{\text {th }}$ order polynomial sometimes proved a better fit in terms of $\mathrm{R}^{2}$ values. However, more elaborate equations may simply provide progressively greater precision while accounting for biologically meaningless variation.

Age structure. Scattergrams of dbh versus age for all cored trees at the five study sites are shown in Figure 4.7. Plots within sites were similar in species composition, structure, and site conditions, as well as physically close to each other $(<100 \mathrm{~m}$ apart $)$. With the assumption that plot-pairs were subject to the same disturbance regime, I pooled data from the two plots at each study location (Lorimer 1985). With two exceptions, diameter was a poor predictor of age because: a) shade tolerant species may persist for a long time in lower canopy positions, and undergo several suppressions and releases before reaching the overstory, and b) because of the area-based sampling technique, the sample sizes for some species were relatively small, and some species occurred only as large dominant stems with a small diameter range (e.g., white oak at Wrights Woods). Linear regression did yield satisfactory relationships for oaks at Murphy Tract and Horners Woods, where sample sizes were larger and trees more diverse in age and diameter. There, I used the linear regression equations to estimate ages of seven white oaks at Murphy Tract, and four chestnut oaks at Horners Woods that had rot in the pith area $\left(\mathrm{R}^{2}=0.753\right.$, 0.589 , respectively, $\mathrm{p}<0.001)$.

Two trends characterized the age structure and oak recruitment at these sites. First, at Wrights Woods and Collins Woods, establishment of oaks was limited to the period 1650-1875. White oaks were the oldest trees; red oaks first recruited between 1750-1800 and continued until 1850 at Wrights Woods, and 1875 at Collins Woods. Both sites experienced a large ingrowth of shade tolerant trees such as red maple, sugar maple, and American beech in the $1800 \mathrm{~s}$, 
accompanied by the recruitment of several pioneer species_-yellow poplar, American elm, and pignut hickory (Carya glabra [Mill.] Sweet) at Collins Woods, and black cherry and red elm (Ulmus rubra Muhl.) and American elm at Wrights Woods. At Collins Woods, the establishment was gradual over a 50 year period beginning in 1850, while at Wrights Woods establishment was quite abrupt, beginning in 1890. For these two sites, white oak recruitment virtually stopped in 1800, and red oak in the mid-1850s. Wrights Woods was the best example of this trend, with the youngest white oak and red oak dating to 1805 and 1852, respectively.

The second trend occurred at Murphy Tract, Horners Woods, and Watter Smith, and resembled the first in several respects. The oldest trees were white oaks and chestnut oaks that were established in the mid-1600s (not until 1687 for Watter Smith). Red oaks and black oaks were recruited beginning in the early 1800s. These three sites also had a gradual ingrowth of both shade tolerant and pioneer species in the 1800 s. However, at these sites, oak recruitment was more or less continuous during the 1800s, and as recent as 1948 at Watter Smith. For example, at Horners Woods, 33\% and 57\% of the white oaks and black oaks, respectively, established after 1850. The trend was clearest at Murphy Tract, where oaks reached breast height in 11 out of 13 decades between 1800-1940.

The age structures of these sites raise questions about stand establishment and stand development. Are the oldest trees members of a single large cohort, recruited after a standinitiating disturbance, or are they remnants of a pre-existing, all aged stand? Where only a small number of old trees are available for study, the answer is at best, an estimate, but juvenile growth rates of these trees can suggest whether they originated in the understory under partial shade, or in a gap. Distinguishing single tree gap origin from larger disturbances depends on the numbers of trees available for examination. If a large proportion of trees had early growth characteristic 
of gap or open-grown conditions, and they originated in the same time period, then the likelihood is they owe their establishment to a single large disturbance. At Horners Woods and Collins Woods, the large range of establishment times precludes any reliable estimate of stand origin. At Wrights Woods, Murphy Tract, and Watter Smith the oldest trees date to a well-defined time period, and similarities of early growth patterns provide evidence from which a reliable estimate of stand origin can be made.

At Watter Smith, the oldest trees were two white oaks, established in 1687 and 1690. Both had above-average growth rates in the earliest rings, characteristic of open-grown conditions either in a gap, or after a larger disturbance. For example, WS8 (Figure 4.8a) had steady growth and no suppressions or major releases between 1700-present. WS39 (Figure 4.8b) also had above average early growth, but underwent two major releases, first in 1808 , when its dbh (inside bark, dib) was $18.0 \mathrm{~cm}$, and then again in $1853(\mathrm{dib}=29.2 \mathrm{~cm})$. Even though the two trees were $50 \mathrm{~m}$ apart and established under comparable conditions, the small number makes it difficult to tell if they owe their origins to one large disturbance or two isolated but coincident, smaller gap events. Therefore I cored four additional white oaks of comparable size that were nearby, but outside the study plot. Three of these established in the 1690s, and the fourth in 1720, and all had above average early growth rates. These results suggest a single large disturbance as the initiator of this stand.

The large numbers of white oaks of Murphy Tract that date to the 1650s suggest a similar origin. Of the 19 white oaks established between 1644-1687, half had above average juvenile growth rates, and experienced no periods of suppression or subsequent release. Cores MT42 and 2MT18 (Figures 4.8c,d) exemplify these growth patterns. Wrights Woods shows a somewhat similar pattern. Five white oaks recruited between 1650-1680, and four of these date to the 
period 1665-1671. One tree, WW19, had a very low early growth rate $\left(<1 \mathrm{~mm} \mathrm{yr}^{-1}\right)$, suggesting it originated under a pre-existing canopy. The remaining four trees all had above average juvenile growth rates (e.g., WW8, Figure 4.8e). Wrights Woods was unusual in that the appearance of a second large cohort of sugar maple and black cherry in 1890 suggests a second large disturbance. The similarity of establishment dates and early growth trends of the oldest trees suggest both stands they own their origin to a large disturbance rather than small, isolated events characteristic of gap-phase replacement in a pre-existing stand.

Coarse woody debris. Tree mortality is the main input of CWD, and thus the distribution of CWD may strongly relate to disturbance patterns and the stage of stand development (Muller and Liu 1991, McCarthy and Bailey1994). The volume of down logs (snaps and tipovers) averaged $70.0 \pm 22.3 \mathrm{~m}^{3} \mathrm{ha}^{-1}$ across all plots, with a range of 28.8-103.6 $\mathrm{m}^{3}$ $\mathrm{ha}^{-1}$, somewhat greater than the range cited by Tyrrell et al. (1998) for mesic northern oak forests (20.8-68.8 $\mathrm{m}^{3} \mathrm{ha}^{-1}$, see Table 4.8). The density of snags ( $\mathrm{dbh} \geq 15 \mathrm{~cm}$ ), whether measured by basal area $\left(3.2 \mathrm{~m}^{2} \mathrm{ha}^{-1}\right)$ or number of snags $\left(22 \mathrm{ha}^{-1}\right)$, was also comparable to the range for this cover type (Tyrrell et al. 1998). Snags comprised approximately $10 \%$ of both the live basal area and live trees $\mathrm{ha}^{-1}(\mathrm{dbh}>15 \mathrm{~cm})$, with surprisingly little variation among sites. This ratio compares closely with surveys from midwestern states (11\%, Spetich et al. 1999), but is higher than surveys of a mixed mesophytic forest in eastern Kentucky (4\%, Martin 1992), and southern mixed hardwood stands (4\%, Batista and Platt 1997).

Due in part to the selection of sites where oaks were codominant at minimum, oaks comprised the majority of CWD. By volume and basal area, oak species averaged $75 \%$ of downed logs and $59 \%$ of standing snags (Table 4.8). However, there was only a weak correlation between oak IV and percentage oak logs $(r=0.313)$, and percentage oak snags $(r=$ 
0.350). In fact, the proportion of oak CWD was highest where live oak IV was lowest. For example, at Wrights Woods, oaks were limited to a few, very large overstory trees, yet over $85 \%$ of the volume of downed logs consisted of white oak and red oak. This reflects both the lack of recruitment of oak at these sites, and differential mortality in the largest size classes discussed earlier. Given the small number of surviving canopy oaks there, this trend will undoubtedly change. In contrast, where oaks were more abundant, both in terms of number of live trees and different oak species, the distribution of CWD more closely paralleled the species IV. Thus, for example, at the two Horners Woods plots, black oak was the dominant oak present, and it had a much larger portion of CWD than white oak. The one notable exception occurred at Murphy Tract2, where scarlet oak (Quercus coccinea Muenchh.), a shade intolerant and short-lived species, comprised $30 \%$ of the volume of downed logs and $64 \%$ of the snag basal area, even though its IV was only 4.

When the diameter distributions of live and dead trees $(\mathrm{dbh}$, base diameter $\geq 15 \mathrm{~cm})$ for each plot were compared using the non-parametric Kolmogorov-Smirnov test, there were no significant differences between the shapes of the diameter distributions $\left(\mathrm{KS}_{\text {stat }}<0.450, \mathrm{p}>\right.$ 0.336, $\mathrm{df}=8)$. Densities of CWD were highest in the $20 \mathrm{~cm}$ size class $(15-25.4 \mathrm{~cm})$, and tapered to a minimum in the largest size classes (Figure 4.9). However, consistent with the plateaus in the distribution of live stems, the slopes of the curves were interrupted by lower peaks in the 30$50 \mathrm{~cm}$ size classes. The ratios of the numbers of dead logs and snags to live stems by size class suggest that these stands are in equilibrium with respect to CWD (Table 4.9). The one exception was Wrights Woods2, where there were four snags/logs but only one live tree in the $60 \mathrm{~cm}$ size class. Excluding Wrights Woods2, the average ratio for eight plots was $0.37 \pm 0.29$, while the average by size-class was $0.39 \pm 0.31$. Thus, a relatively constant proportion of trees in each plot 
and diameter class become a snag or downed log. Even with Wrights Woods2 included, there were no significant differences between average ratios for plots or size classes (ANOVA, plots: $\mathrm{F}=1.7, \mathrm{p}=0.12$, size class: $\mathrm{F}=0.60, \mathrm{p}=0.78)$

The spatial distribution of snaps and tipovers was strongly influenced by the size of the sampling unit. At the $15 \mathrm{~m}$ and $30 \mathrm{~m}$ scales, the spatial distribution of downed logs was clumped using the Morisita Index of Dispersion $\left(\mathrm{I}_{\mathrm{d}}\right)$, but became randomly distributed at larger scales (Figure 2.10). A similar trend was suggested by $I_{d}$ values for snags, although values for clumped dispersion at the $15 \mathrm{~m}$ scale were statistically significant at only two plots (Horners Woods1 and Murphy Tract2). The distribution of CWD within a stand is patchy by nature (Harmon et al. 1986). Many causes of event-related mortality, such as slides and windthrow affect patches of adjacent trees. Given average tree heights of $\sim 30 \mathrm{~m}$, it seems reasonable that the patch size where clumping changes to a more random distribution appears at this distance.

The orientation of downed logs, however, was not strongly related to slope aspect in these study sites (Figure 4.11); trees are about as likely to fall uphill as down. Nor was there any clear correlation between direction of fall and prevailing, southwesterly winds. Except in the strongest winds, trees are not just pushed over by the sheer force of the wind, but sway back and forth at their resonant frequency (Ennos 1997). As a tree rocks, an unbalanced crown or a leaning bole may be more influential than wind direction in determining direction of fall. In tropical forests, tree crowns tend to grow away from near neighbors (Young and Hubbell 1991; Young and Perkocha 1994). Crown asymmetries produced in response to the shade from neighbors resulted in the tendency for trees to fall into older gaps and away from their neighbors, rather than downwind. Similar results were noted for broad-leaved trees in Finland (Falinski 
1986). Trees fall away from neighbors on their heavier sides, largely independent of wind direction.

Canopy gaps. In unmanaged old-growth forests in the temperate region, small canopy gaps are the principle source of new recruits to the overstory (Runkle 1982; Valverde and Silverton 1997), particularly when large disturbances are relatively infrequent. Species diversity is maintained and replenished as different tree species establish in niches along environmental and resource gradients from gap center to edge (Runkle 1982; Sipe and Bazazz 1994), and simply by the fact that gaps are centers of high stem density (Denslow 1985; Busing and White 1997). The sampling technique of this study was too restricted to test either of these hypotheses. For example, several gaps occurred along the border of the study plot, and only the area inside plot boundaries was sampled. Study plot size was tailored to study a small area over a long period of time, and the site selection criteria favored areas that had an intact canopy. However, the small plot size was less suitable for sampling short-term changes (ca 10 years), and thus did not yield a good representation of more recent stand- or forest-level gap dynamics.

Twenty-one canopy gaps occurred either completely or partially within the nine study plots. One plot, Wrights Woods1 had four gaps, while its companion plot, Wrights Woods2, had one large older gap that was nearly closed and thus not sampled. Average gap size was $94 \pm 47$ $\mathrm{m}^{2}$, and the percentage of study plots in gaps less than ten years old was $4.6 \%$ (Table 4.10 ), both somewhat less than averages for eastern deciduous forests (Runkle 1982; Lorimer 1989; Romme and Martin 1992). Mean gap size and percentage in gaps were not significantly different among sites $(\mathrm{F}=2.84, \mathrm{p}=0.168)$. Eighteen of the 21 gaps were caused by falls/death of one or two trees, and larger dominant-codominant oaks were by far the most common gap maker (Figure 4.12a), confirming the preponderance of oaks found as CWD. Trees in the $50 \mathrm{~cm}$ dbh class were 
notably lower in the diameter distribution of gap makers. While this may have been an artifact of a small sample size, it is consistent with the higher number of live trees (and by implication, lower mortality) in this class. Snaps were the most frequent cause of tree death (46\%), followed by snags (32\%), and tipovers (21\%). While large oaks were most likely to create gaps, smaller maples (dbh $<15 \mathrm{~cm}$ ), principally sugar maple, were the most common gap fillers (Figure 4.12b). In the ordination of the gap and understory plots, each gap was most similar to and grouped with the advance regeneration in the understory, and the small tree plot $(\mathrm{dbh}<15 \mathrm{~cm})$ for its respective site (Figure 4.13). This is consistent with the small gap size, and a gap diameter to canopy height $(\mathrm{D} / \mathrm{H})$ ratio that is less than 1 .

Despite the relatively small average gap size and the preponderance of maples and beech as gap successors, there is some evidence that the gap regime was sufficient for some less tolerant tree species to capture gaps. For example, a white oak sapling $(10.3 \mathrm{~cm} \mathrm{dbh})$ shared a gap with smaller beech $(6.5,9.6 \mathrm{~cm}$, ) and one red maple $(7.1 \mathrm{~cm})$ at Murphy Tract2, and pignut, bitternut (Carya cordiformis [Wang.] K. Kock), and mockernut hickory (C. tomentosa [Poir.] Nutt.), and black birch (Betula lenta L.) were potential gap fillers at four different locations, although they were not always the largest stem. Yellow-poplar filled one small gap at Watter Smith, although because of its large size ( $\mathrm{dbh} 22.4 \mathrm{~cm}$, ht, $22.6 \mathrm{~m}$ ), it probably originated in an adjacent canopy gap that was enlarged by a subsequent treefall. 


\section{Discussion}

Disturbances have a profound effect on forest development, and evidence of this relationship is contained in the composition and structure of these study sites. The sites all have some evidence of human disturbance, whether direct (stumps remaining from selective logging, roads) or more indirect (chestnut blight, livestock grazing, and high deer browse). Nevertheless, these stands have never been cleared, and are several hundred years removed from a major natural disturbance. The age structures of Wrights Woods, Watter Smith, and Murphy Tract strongly suggest the time of stand origin. In terms of the stage of stand development, these stands are transitional old-growth (cf. Oliver and Larson 1996). Even-aged remnants of the stand-initiating cohort remain, but uneven-aged younger cohorts occupy a large portion of the canopy. At Wrights Woods, the similarity of establishment times of sugar maple and black cherry beginning in 1890 point to an additional large disturbance, and suggest that this is better termed a multi-cohort stand, although distinctions between old-growth and multi-cohort stands can be arbitrary (Oliver and Larson 1996). For Collins Woods and Horners Woods, evidence of a stand-initiating event is ambiguous, and these sites are potentially true old growth (cf. Oliver and Larson 1996). However, the small number of old trees and a wider age range make it difficult to determine if they are survivors of a large disturbance initiated and even-aged cohort, or remnants of a small cohort in a stand that has been uneven-aged for centuries.

Oliver and Larson's (1996) delineation of the stages of stand development is based on stand structure and not species composition; species changes may accompany changes from one stage to another, but not always. Where the change from even-aged to uneven-aged involves a distinct change in species composition with different shade tolerances and growth strategies (for 
example, western hemlocks [Tsuga heterophylla (Raf.) Sarg.] coexisting with and eventually replacing Douglas-fir [Pseudotsuga menziesii (Mirb.) Franco] in forests of the Pacific Northwest), the boundary between transitional and true old-growth is readily determined. In eastern hardwoods that often occur as single cohort stands, and where single cohort and multicohort stands often have similar species composition, a rigorous determination of the stage of stand development and future species composition is more difficult (C. Lorimer, per. comm.). The present species composition and structure of Collins Woods and Wrights Woods suggest that the importance of shade-tolerant non-oak species will increase in the future, barring a large disturbance. At Wrights Woods, the average vigor of the oldest white oaks is nearly one unit higher (less vigorous) than younger overstory sugar maples. The absence of oak saplings and poles, the limitation of oaks to largest size classes, the absence of any oak recruitment since 1875 (much longer for white oak), and the preponderance of oak CWD all point to their impending replacement. This is clearest at Wrights Woods, where dead oaks outnumber live ones in some larger size classes. At Watter Smith, Murphy Tract, and Horners Woods, oaks form a much more vigorous, numerous, and diverse component of the overstory, and the future composition is less certain. Some measure of oak dominance at these sites can be attributed to the influence of site quality. For example, Murphy Tract represents a good example of what is termed an "oak site," with a southwest aspect, upper slope position, and relatively thin, droughty soils. These site factors offer oaks better chances to compete with more mesic, shade tolerant species. On average at these three sites, oak average vigor ratings equaled or exceeded those for overstory sugar maple and beech. Oaks were better distributed among age- and size-classes, and were found in all canopy classes. Oak recruitment occurred continuously from the $1800 \mathrm{~s}$ through the mid-1900s. 
At times the impact of disturbance on stand composition and structure was gradual and constant. For example, canopy recruitment of both oaks and shade tolerant species during the 1800s and early 1900s occurred in virtually every decade for all sites but Wrights Woods, suggesting that canopy disturbances were frequent and asynchronous. At other times, tree establishment was quite episodic. The stand initiating events, as defined above, are clear examples. The appearance of a large cohort of sugar maple, black cherry, and elm at Wrights Woods beginning in 1890 is another. Of a total of 46 trees, 39 were established between 18901910.

The uneven development of these stands is also exemplified by the presence of large gaps in their age structures. This is most apparent at Watter Smith, which had two white oaks established in 1690, and then no new trees until 1800. According to Oliver and Larson's (1996) theory of stand development, large disturbances are followed by an initial wave of regeneration. When the surviving stems form a closed canopy, new growing space becomes available when poor competitors die, but during this period of self-thinning (density-dependent mortality [Peet and Christensen 1987]), the newly released resources are rapidly appropriated by surviving canopy trees. Not until the understory reinitiation phase, when abrasion of the crowns of canopy trees occurs, high shade develops, and canopy trees begin to die from exogenous forces, does enough light penetrate the forest canopy to allow germination and growth of potential canopy successors. The time period between stand initiation and understory reinitiation varies by species and site. It may be shorter on droughty sites than mesic ones, and where less shade tolerant species are dominant (Oliver and Larson 1996). Understory reinitiation occurred after 40-60 years for intolerant southern pine stands (Peet and Christensen 1987), 80-90 years for 
mixed oak, maple and birch stands (Oliver and Larson 1996), and 150 years on clearcut northern hardwoods in New England (Bormann and Likens 1979).

For the three stands whose age distribution most strongly suggest a catastrophic origin (Watter Smith, Murphy Tract, Wrights Woods), the empty age classes following initial establishment are consistent with a pause in recruitment until the stands reached understory reinitiation phase. After Murphy Tract establishment in 1645-1665, new canopy trees, primarily oaks, were recruited sporadically between 1685-1720. The recruitment of black gum, an opportunistic species (Hicks 1998), in 1702 suggests the possibility of canopy gap formation. By the early 1800s, when hickories, red maple, and beech established, the oldest disturbanceinitiated oaks reached overstory size, with an average of 19.9-24.0 cm. At Wrights Woods, the best estimate of the time of stand initiating disturbance dates to the four trees established 16651671. Northern red oak, the tree most likely to be capable of filling canopy gaps, began appearing in 1780 , when the oldest oaks average dib was $22.8 \mathrm{~cm}$, after an interval of about 100 years, consistent with average time between stand initiation and understory reiniation on a better sites. Watter Smith also has an age structure that appears consistent with a stand initiating disturbance, and a 100 year recruitment pause between stand initiation and red oak and white ash recruitment $($ dib of oldest oaks $=19.7 \mathrm{~cm})$.

However, an empty age class does not necessarily mean that the slot was always empty (Johnson et al. 1994). Gaps in an age distribution may stem from mortality as well as the absence of recruitment. Uncertainty in distinguishing between no recruitment and recruitment followed by (early) mortality is especially high when long chronologies are reviewed. Stand reconstructions that evaluate microtopography, and dead as well as live wood have been used to 
study succession over several hundred years (e.g., Henry and Swan 1974), but these require considerable effort, and the size and number of the study area has practical limits.

Sugar maple and beech are potentially as long lived as white oak (Burns and Honkala 1990), yet none of these sites had these species in the oldest cohort. Two reasons may account for the absence of non-oaks in the oldest cohort. First, they may have recruited and died. This is certainly possible with red maple and hickories at Murphy Tract. Site conditions in the aftermath of the initial large disturbance would be favorable for both species, assuming a seed source or advance regeneration were present. However, neither are as long lived as white oak (Iverson et al. 1999), and had they been a component of the initial stand, they would not necessarily be present today.

At the other sites, the absence of sugar maple and beech suggests another dynamic. As seedlings and saplings, these species are highly susceptible to damage, topkill, and mortality from low intensity ground fires (Burns and Honkala 1990; Iverson et al. 1999). In contrast, oak acorns germinate well on mineral soil after low intensity surface fires (Iverson et al. 1999). Oak seedlings sprout readily after fire topkill (Barnes and Van Lear 1999; Huddle and Pallardy 1999), and trees are relatively fire resistant because of thick, deeply furrowed bark (Burns and Honkala 1990; Abrams 1992). Oaks not only survive fire, they also benefit from the removal of tall understory shade (Lorimer et al. 1994). There is convincing evidence that the dominance of oak in presettlement-era forests can be attributed, in part, to the frequency of surface fires set by native Americans (Bromley 1935; Day 1953; Buell et al. 1954; Abrams 1992; Bonnicksen 2000). Settlers continued this practice through the 1800s (Van Lear and Waldrop 1989; Abrams 1992; Sutherland 1997). The potential link between high fire frequency and low levels of sugar maple, 
red maple, and beech in presettlement forests (at least compared to current standards) was born out by the analysis of early land surveys in Chapter 2 .

Collins Woods and Horners Woods are the most likely candidates for satisfying the characteristics of a true old-growth stand: they lack an identifiable old, disturbance-initiated cohort, and have a more or less all-aged structure. If true, then this condition should have resulted in a sizeable pool of sugar maple and beech in the understory, their periodic canopy accession as canopy gaps were created, and their presence today in the older cohorts. This, however, was not the case. At Collins Woods, the oldest maples and beech date to the 1850s. Coincidentally, the last surviving oak was established in 1875 . These complementary trends are consistent with the fire history of Dysart Woods, an oak dominated old-growth stand approximately $20 \mathrm{~km}$ from Collins Woods. Reviewing the fire history of one old white oak, McCarthy et al. (2001) found 27 fire scars between 1731-1990; two scars occurred after 1850, and none since then. Similar results were reported from oak stands at the periphery of the central hardwood forest by Guyette and Cutter (1994). In sum, while this study does not include data on fire frequency, information from other studies accounts in part for the establishment patterns of fire-susceptible species such as sugar maple and beech.

The unevenness of establishment, growth, and death is also shown in the size structure of these stands. According to the negative exponential model — the reverse, J-shaped curve — there is a more or less constant percentage loss (mortality) of trees from one diameter class or agecohort to the next larger one across the entire range of diameters in a stand (Leak 1964, 1973; Martin 1992; Greenberg et al. 1997). This model has been verified for 1) stands where mortality is primarily the result of density-dependent self-thinning within age (size) groups, and 2) large surveys over extensive areas, containing many stands (Goff and West 1975). However, for the 
structurally uniform stands of this study, a rotated sigmoid curve provided a better fit of diameter distributions. The variability in slope suggests that growth and mortality are not constant; a mortality curve would be U-shaped (Harcombe 1987). Goff and West (1975) attributed this difference to the impact of vertical structure, and the fact that in such stands there are really two populations of trees with different mortality curves: the understory, in which growth is retarded and seedling and sapling mortality high, and the overstory. The latter can be further divided into those younger, more vigorous overstory stems that have recently reached the canopy, and that show a much lower probability of dying than the oldest trees (Peet and Christensen 1987), that are approaching their maximum age, and which are more vulnerable to disease, wind, and other causes of death (Waring 1987). Schmelz and Lindsey (1965) believed that deviations from the reverse J-shaped distribution for midwestern old-growth hardwoods represented a temporary stage of recovery from an earlier disturbance, and they proposed an index of disturbance based on how much the density distribution differed from the model. However, where frequent, small canopy disturbances characterize the disturbance regime (Runkle 1982, 1985, 1990; Lorimer 1989), forests are in a constant state of disturbance and recovery, and thus the rotated sigmoid distribution better reflects the "normal" condition.

The general pattern of individual tree growth is well known (Fritts 1977; Kramer and Kozlowski 1979). Small, overtopped trees grow slowly. As they move into the canopy, their live crown ratios reach a maximum, as well as diameter and volume accretion. This point of canopy entry is consistent with the plateaus shown in the diameter distributions. Although there was variability between sites, the onset of the flattened portion of the diameter distribution generally occurred around the $20-40 \mathrm{~cm}$ dbh (Figure 4.6). Gough and West (1975) found that the plateau widened and moved to the right as stands aged — as they grew larger and taller. For 
example, Collins Woods plots had greater average canopy tree dbh's and heights than Murphy Tract (Table 4.3), and much wider plateaus. Correlation analysis show positive correlations between plateau width and average canopy tree $(\mathrm{dbh}>15 \mathrm{~cm})$ diameter and height $(\mathrm{r}=0.71$, 0.53 , respectively), but not average crown size $(\mathrm{r}=-0.19)$.

For older codominants, height growth eventually slows and horizontal crown expansion requires death of neighboring trees. Diameter grow also slows as tree biomass increases, the annual increment is spread over an increasing circumference, and the ratio of photosynthetic to nonphotosynthetic tissue decreases (Harcombe 1987; Oliver and Larsen 1996). Physiological changes accompany changes in growth rate. These include a decrease in metabolism, loss of apical dominance, heartwood formation, slower wound healing, and branch dieback (Kozlowski 1971). Taller trees have unique problems associated with movement of soil water to heights of $30 \mathrm{~m}$ or more. In taller, older trees, these problems are aggravated by tissue changes associated with their age, size, and carbon balance (Ryan and Yoder 1997). All of these changes make trees more susceptible to environmental stress and disease agents (Kozlowski 1971; Franklin et al. 1987; Waring 1987).

In sum, the reverse-J shaped distribution has traditionally been found as a characteristic of unmanaged, eastern old growth forests (Meyer 1950; Schmelz and Lindsay 1965; Greenberg et al. 1997). Martin's (1992) definition of old-growth for eastern mixed mesophytic forests included this characteristic. However, other forms have been predicted through computer simulation or defined by field measurements, and Leak (1996) cautions that this is not surprising, since population theory suggests that there is an infinite number of sustainable age/diameter structures, all with different birth, growth, and mortality schedules. For the five old-growth 
stands of this study, the rotated sigmoid form of the density diameter distribution better accounts for their variable rates of growth and death, and is therefore biologically more reasonable.

\section{Conclusion}

The notion of old-growth invokes different meanings to different people. Presented with an opportunity to review stand history over a long period, forest ecologists have a natural attraction to old-growth, and these forests have played a prominent role in the development of ecological theory. Indeed, as Gordon Whitney (1987) noted, this attraction may in fact be an occupational hazard. To a certain extent, much of the modern preservationist sentiment represents an extension of Clements' (1916) views on natural succession and the climax, and is grounded in the assumption that because forests are old, they are stable, unchanging, and represent original conditions unaltered by modern-era humans.

Data from the five sites of this study show the opposite is true. The course of stand development has been dramatic and episodic at some times; at others, disturbance and tree replacement have been more gradual and persistent. The abundant CWD on the forest floor and canopy gaps are obvious casualties of recent natural disturbance. The nearly constant ratios of dead to live trees across all sites and all size classes that suggest that tree death, and the disturbances that caused them, are in rough equilibrium, and thus the current distribution of CWD is not an aberration. The size structures of these stands also point to the variability of tree growth and death. Trees reaching overstory-size dbh show increased vigor but after a certain point, large diameter is linked to increased probability of dying. Finally, the age structures attest to the influence of disturbances of varying intensities and consequences at different times. Some 
stands probably owe their origins to large $17^{\text {th }}$ century events. In the aftermath of stand reorganization, relatively few new individuals recruited until stand development progressed to the understory reinitiation stage, a period of about 100 years. Since then, tree establishment on these sites has been mostly gradual, persistent, and asynchronous. Canopy replacement occurred one or two trees at a time, in contrast to the large cohorts formed at time of stand initiation. These more recent additions to the overstory could only have occurred if the former occupants of that space died, and the recruitment rate is possible only if canopy disturbance and tree death occurred at a similar rate.

The white oaks that initially populated the stands were well-suited for the environment that was created. Indeed, the challenge of oak silviculture today is how to recreate the overstory and understory conditions under which these early stands established. The fact that species compositions are changing for some stands suggests that other forms of disturbances are influential. 


\section{Acknowledgements}

A host of people helped in the location of suitable study sites, stand inventories, and collection of dendrochronological data. William Wentzel, a forester with the Pennsylvania Department of Conservation and Natural Resources, was especially helpful in showing me several candidates old-growth study sites in Greene and Washington Counties, PA. Ed Grafton and Tom Tanner, Glenville State College, Glenville, WV, spent the better part of a day with me in Gilmer County, WV, and Mark Clarke, of the Wildlife Resources Section of the WV Division of Natural Resources provided much assistance for a survey of the Elk River Wildlife Management Area near Sutton, WV. Dan Parker, a forester in Boone County, helped in evaluating a site near Danville, WV. Chad Smith, Jude Seth, James O’Connor, Tom Zerbe, Jake Ott, and Ron Fortney, all provided field assistance. Aaron Graves and Wade Dorsey, fellow graduate students in the Division of Forestry, and Lukas Rentch, my nephew, were all particularly generous with their time and expertise.

Permission to conduct research was generously granted by the following individuals and organizations. 1) Collins Woods: Mark Swiger, Muskingum Watershed Conservation District, New Philadelphia, OH; 2) Wrights Woods: Rev. J. P. Hilliard, Wright's United Methodist Church, Venetia, PA; 3) Horners Woods: Ray Knotts, WV Division of Natural Resources, French Creek, WV; 4) Watter Smith State Park: Kim McHenry and Larry Jones, West Virginia State Parks, Charleston, WV; and 5) Murphy Tract: Tina Hall, The West Virginia Nature Conservancy, Elkins, WV. 


\section{Literature cited}

Abrams, M. D. 1990. Adaptations and responses to drought in Quercus species of North America. Tree Physiology 7: 227-238.

Abrams. M. D. 1992. Fire and the development of oak forests. BioScience 42: 346-353.

Abrams, M. D. and J. A. Downs. 1990. Successional replacement of old-growth white oak by mixed mesophytic hardwoods in southwestern Pennsylvania. Can. J. For. Res. 20: 1864-1870.

Abrams, M. D., C. A. Copenheaver, K. Terazawa, K. Umeki, M. Takiya, and N. Akashi. 1999. A 370-year dendroecological history of an old-growth Abies-Acer-Quercus forest in Hokkaido, northern Japan. Can. J. For. Res. 29: 1891-1899.

Bailey, R. G. (comp.) 1995. Description of the ecoregions of the United States. USDA For. Ser. Misc. Pub. 1391.

Barnes, T. A. and D. H. Van Lear. 1998. Prescribed fire effects on advanced regeneration in mixed hardwood stands. South. J. Appl. For. 22: 138-142.

Batista, W. B. and W. J. Platt. 1997. An old-growth definition for southern mixed hardwood forests. USDA For. Ser. Gen. Tech. Rep. SRS-9.

Bazzaz, F. A. 1979. The physiological ecology of plant succession. Ann. Rev. Ecol. Syst. 10: 351-371.

Beck, D. E. and R. M. Hooper. 1986. Development of a southern Appalachian hardwood stand after clearcutting. South. J. Appl. For. 10:168-172.

Bonnicksen, T. M. 2000. America's ancient forests: from the ice age to the age of discovery. John Wiley \& Sons, New York, NY.

Bormann, F. H. and G. E. Likens. 1979. Pattern and process in a forested ecosystem. SpringerVerlag, New York, NY.

Botkin, D. B. Causality and succession. Chapter 5 In West, D. C., H. H. Shugart, and D. B. Botkin, eds. Forest succession: concept and application. Springer-Verlag, New York, NY.

Braun, E. L. 1950. Deciduous forests of eastern North America. Blakiston Company, Philadelphia, PA.

Bromley, S. W. 1935. The original forest types of southern New England. Ecol. Monogr. 5: 6189.

Brooks, A. B. 1910. West Virginia Geological Survey, Vol. 5: Forestry and Wood Industries. Acme Publishing Company, Morgantown, WV. 
Buell, M. F., Buell, H. F., and Small, J. A. 1954. Fire in the history of Mettler's Woods. Bull. Torrey Bot. Club 81:253-255.

Burns, R. M. and B. H. Honkala (tech. coords.) 1990. Silvics of North America. Vol 2. Hardwoods. Agriculture Handbook 654. USDA For. Ser., Washington, DC.

Busing, R. T. 1995. Disturbance and the population dynamics of Liriodendron tulipifera: simulations with a spatial model of forest succession. J. Ecology 83: 45-53.

Busing, R. T. and P. S. White. 1997. Species diversity and small-scale disturbance in an oldgrowth temperate forest: a consideration of gap partitioning concepts. Oikos 78: 562-568.

Caldwell, J. A. 1880. History of Belmont and Jefferson Counties, Ohio. Historical Publishing Company, Wheeling, WV.

Carvell, K. L. and E. H. Tryon. 1961. The effect of environmental factors on the abundance of oak regeneration beneath mature stands. For. Sci. 7: 98-105.

Cho, D. S. and R. E. Boerner. 1991. Canopy disturbance patterns and regeneration of Quercus species in two Ohio old-growth forests. Vegetatio 93: 9-18.

Clements, F. E. 1916. Plant succession: an analysis of the development of vegetation. Carnegie Inst. Pub. 242.

Canham, C. D. 1989. Different responses to gaps among shade-tolerant tree species. Ecology 70: $548-560$.

Canham, C. D., A. C. Finzi, S. W. Pacala, and D. H. Burbank. 1994. Causes and consequences of resource heterogeneity in forests: interspecific variation in light transmission by canopy trees. Can. J. For. Res. 24: 337-349.

Davis, M. B. 1996. Extent and location. Chapter 2 In Davis, M. B., ed. Eastern old-growth forests: prospects for rediscovery and recovery. Island Press, Washington, D.C.

Day, G. M. 1953. The Indian as an ecological factor in the northeastern forest. Ecology 34: 329-346.

Denslow, J. S. 1980. Patterns of plant species diversity during succession under different disturbance regimes. Oecologia 46: 18-21.

Denslow, J. S. 1985. Disturbance-mediated coexistence of species. Chapter 17 In Pickett, S. T. A. and P. S. White, eds. The ecology of natural disturbance and patch dynamics. Academic Press, New York, NY. 
Dickson, R. E. 1994. Height growth and episodic flushing in northern red oak. Pp. 1-9 In. Isebrands, J. G. and R. E. Dickson, comps. Biology and silviculture of Northern red oak in the north central region: a synopsis. USDA For. Ser. Gen. Tech. Rep. NC-173.

Ennos, A. R. 1997. Wind as an ecological factor. TREE 12: 108-111.

Fenneman, N. M. 1938. Physiography of the eastern United States. McGraw-Hill, New York, NY.

Franklin, J. F., H. H. Shugart, and M. E. Harmon. 1987. Tree death as an ecological process. BioScience 37: 550-556.

Frelich, L. E. and L. J. Graumlich. 1994. Age-class distribution and spatial patterns in an oldgrowth hemlock-hardwood forest. Can. J. For. Res. 24: 1939-1947.

Fritts, H. C. 1976. Tree rings and climate. Academic Press, New York, NY.

Gilchrist, J. C. and C. H. Gilchrist. 1993. A pictorial history of Lewis County: the crossroads of central West Virginia. Downing Publishing Co., Virginia Beach, VA.

Goebel, P. C. and D. M. Hix. 1996. Development of mixed-oak forests in southeastern Ohio: a comparison of second-growth and old-growth forests. For. Ecol. Manage. 84: 1-21.

Goff, F. G. and D. West. 1975. Canopy-understory interaction: effects on forest population structure. For. Sci. 21: 98-108.

Goodall, D. W. and N. E. West. 1979. Comparison of techniques for assessing dispersion patterns. Vegetatio 40: 15-27.

Goodburn, J. M. and C. G. Lorimer. 1999. Population structure in old-growth and managed northern hardwoods: an examination of the balanced diameter distribution concept. For. Ecol. Manage. 118: 11-29.

Greenberg, C. H., D. E. McLeod, and D. L. Loftis. 1997. An old-growth definition for western and mixed mesophytic forests. USDA For. Ser. Gen. Tech. Rep. SRS-16.

Grime, J. P. 1977. Evidence for the existence of three primary strategies in plants and its relevance to ecological and evolutionary theory. Am. Nat. 111: 1169-1194.

Grissino-Mayer, H. D., Holmes, R. L., and Fritts, H. C. 1997. The international tree-ring data bank program library version 2.1 user's manual. Laboratory of Tree-Ring Research, Univ. of Arizona, Tuscon, AZ.

Guyette, R. P. and B. E. Cutter. 1991. Tree-ring analysis of fire history of a post oak savanna in the Missouri Ozarks. Natural Areas Journal 11: 93-99. 
Heinselman, M. L. 1971. The natural role of fire in northern conifer forests. In Slaughter, C. W., R. J. Barney, and G. M. Hansen, eds. Fire in the northern environment - a symposium. USDA For. Ser., Pacific Northwest Forest and Rand Experiment Station, Portland, OR, pp. 6172.

Henry, J. D., and Swan, J. M. A. 1974. Reconstructing forest history from live and dead plant material - an approach to the study of forest succession in southwest New Hampshire. Ecology 55:772-783.

Hicks, R. R., Jr. 1998. Ecology and management of central hardwood forests. John Wiley \& Sons, New York, NY.

Hicks, R. R., Jr. 1998. Comparison of ecological characteristics of three remnant old-growth woodlots in Belmont County, Ohio. Unpub. Report to The Ohio Valley Coal Company, Alledonia, $\mathrm{OH}$.

Higbee, E. 1999. The Wright family. <http://www.gbgm-umc.org/wrights/wrights.html>

Harcombe, P. A. 1987. Tree life tables. BioScience 37: 557-568.

Huddle, J. A. and S. G. Pallardy. 1999. Effect of fire on survival and growth of Acer rubrum and Quercus seedlings. For. Ecol. Manage. 118: 49-56.

Hunter, M. L., Jr. and A. S. White. 1997. Ecological thresholds and the definition of old-growth forest stands. Natural Areas Journal 17: 292-296.

Huston, M. A. 1996. Models and management implications of coarse woody debris: impacts on biodiversity. Pp. 139-143 In McMinn, J. W., and D. A. Crossley, Jr., eds. Biodiversity and coarse woody debris in southern forests. Proc. of the workshop on coarse woody debris in southern forests: effects on biodiversity. USDA For. Ser. Gen. Tech. Rep. NC-188.

Iverson, L. R., A. M. Prasad, B. J. Hale, and E. K. Sutherland. 1999. Atlas of current and potential future distributions of common trees of the eastern United States. USDA For. Ser. Gen. Tech. Rep. NE-265.

Johnson, E. A., K. Miyanishi, and H. Kleb. 1994. The hazards of interpretation of static age structures as shown by stand reconstructions in a Pinus contorta-Picea engelmannii forest. J. Ecology 82: 923-931.

Kent, M. and P. Coker. 1992. Vegetation description and analysis: a practical approach. John Wiley \& Sons, New York, NY.

Kern, J. R. 1980. Historic resources evaluation, Stonewall Jackson Lake Project, West Fork River, West Virginia. US Dept. of the Army, Corps of Engineers, Pittsburgh District, Pittsburgh, PA. 
Kozlowski, T. T. 1971. Growth and development of trees. Academic Press, New York, NY.

Kramer, P. J. and T. T. Kozlowski. 1979. Physiology of woody plants. Academic Press, New York, NY.

Krebs, C. J. 1999. Ecological Methodology. Benjamin Cummings, Menlo Park, CA.

Leak, W. B. 1964. An expression of diameter distribution for unbalanced, uneven-aged stands and forests. For. Sci. 10: 39-50.

Leak, W. B. 1996. Long-term structural change in uneven-aged northern hardwoods. For. Sci. 42: $160-165$.

Lieberman, M., D. Lieberman, and R. Peralta. 1989. Forests are not just Swiss cheese: canopy stereogeometry of non-gaps in tropical forests. Ecology 70: 550-552.

Lorimer, C. G. 1980. Age structure and disturbance history of a southern Appalachian virgin forest. Ecology 61: 1169-1184.

Lorimer. C. G. 1985. Methodological considerations in the analysis of forest disturbance history. Can. J. For. Res. 15: 200-213.

Lorimer, C. G. 1989. Relative effects of small and large disturbances on temperate hardwood forest structure. Ecology 70: 565-567.

Lorimer, C. G. 1993. Causes of the oak regeneration problem. Pp. 14-39 In Loftis, D. L. and C. E. McGee, eds. Oak regeneration: serious problems, practical recommendations. USDA For. Ser. Res. Pap. NE-356.

Lorimer, C. G. and L. E. Frelich. 1988. Estimating gap origin probabilities for canopy trees. Ecology 69: 778-785.

Lorimer, C. G. and L. E. Frelich. 1989. A methodology for estimating canopy disturbance frequency and intensity in dense temperate forests. Can. J. For. Res. 19: 651-663.

Lorimer, C. G., J. W. Chapman, and W. D. Lambert. 1994. Tall understory vegetation as a factor in the poor development of oak seedlings beneath mature stands. J. Ecology 82: 227-237.

Loucks, O. L. 1970. Evolution of diversity, efficiency, and community stability. Amer. Zool. 10: $17-25$.

McCarthy, B. C. and R. B. Bailey. 1994. Distribution and abundance of coarse woody debris in a managed forest landscape of the central Appalachians. Can. J. For. Res. 24: 1317-1329. 
McCarthy, B. C., C. J. Small, and D. L. Rubino. 2001. Composition, structure and dynamics of Dysart Woods, an old-growth mixed mesophytic forest of southeastern Ohio. For. Ecol.

Manage. 140: 193-213.

McCune, B. and M. J. Mefford. 1997. PC-ORD. Multivariate analysis of ecological data, version 3.0. MjM Software Design, Glenedon Beach, OR.

McGee, C. E. 1984. Heavy mortality and succession in a virgin mixed mesophytic forest. USDA For. Ser. Res. Pap. SO-209.

McQuilken, R. A. 1990. Quercus prinus L., chestnut oak. In Burns, R. M. and B. H. Honkala, tech. coords. Silvics of North America. Vol 2. Hardwoods. Agriculture Handbook 654. USDA For. Ser., Washington, DC.

Marks, P. L. 1975. On the relation between extension growth and successional status of deciduous trees of the Northeastern United States. Bull. Torr. Bot. Club. 102: 172-177.

Marquis, D. A., P. L. Eckert, and B. A. Roach. 1976. Acorn weevils, rodents and deer all contribute to oak regeneration difficulties in Pennsylvania. USDA For. Ser. Res. Pap. NE-356.

Martin, W. H. 1992. Characteristics of old-growth mixed mesophytic forests. Natural Areas Journal 12: 127-135.

Meyer, H. A. 1952. Structure, growth, and drain in balanced uneven-aged forests. J. For. 50: 85-92.

Miller, R. N. and Y. Liu. 1991. Coarse woody debris in an old-growth deciduous forest on the Cumberland Plateau, southeastern Kentucky. Can. J. For. Res. 21: 1567-1572.

Muick, P. C. 1991. Effects of shade on blue oak and coast live oak regeneration in Californian annual grasslands. In Pillsbury, N. H., J. Verner, and W. D. Tietje (tech. coords.). Proc. of a symposium on oak woodlands: ecology, management, and urban interface issues. USDA For. Ser. Gen. Tech. Rep. PSW-126.

Nowacki, G. J. and M. D. Abrams. 1992. Community, edaphic, and historical analysis of mixed oak forests of the Ridge and Valley Province of central Pennsylvania. Can. J. For. Res. 22: 790800 .

Nowacki, G. J. and M. D. Abrams. 1997. Radial-growth averaging criteria for reconstructing disturbance histories from presettlement-origin oaks. Ecol. Monogr. 67: 225-249.

Nyland, R. D. 1996. Silviculture: concepts and applications. McGraw-Hill, New York, NY.

Oliver, C. D. and B. C. Larson. 1996. Forest stand dynamics. John Wiley \& Sons, Inc., New York, NY. 
Oliver, C. D. and E. P. Stephens. 1977. Reconstruction of a mixed species forest in central New England. Ecology 58: 562-572.

Orwig, D. A. and M. D. Abrams. 1995. Dendroecological and ecophysiological analysis of gap environments in mixed-oak understorys of northern Virginia. Functional Ecology 9: 799-806.

Parker, G. G. 1989. Old-growth forests of the Central Hardwood Region. Natural Areas Journal 9:5-10.

Parker, G. R., D. J. Leopold, and J. K. Eichenberger. 1985. Tree dynamics in an old-growth deciduous forest. For. Ecol. Manage. 11: 31-57.

Peet, R. K. and N. L. Christensen. 1987. Competition and tree death. BioScience 37: 586-595.

Pickett, S. T. A. and M. J. McDonnell. 1989. Changing perspectives in community dynamics: a theory of successional forces. TREE 4: 240-245.

Poulson, T. L. and W. J. Platt. 1981. Dynamics of tree replacement in a beech-maple forest at Warren Woods, Michigan. Bulletin of the Ecological Society of America 62: 135.

Poulson, T. L. and W. J. Platt. 1989. Gap light regimes influence canopy tree diversity. Ecology 70: 553-555.

Richards, R. H., S. R. Shifley, A. J. Rebertus, and S. J. Chaplin. 1995. Characteristics and dynamics of an upland Missouri old-growth forest. Pp. 11-22 In Gottschalk, K. W., S. L. Fosbroke, eds. Proc. $10^{\text {th }}$ annual central hardwood forest conference. USDA For. Ser. Gen. Tech. Rep. NE-197.

Rogers, R. 1990. Quercus alba L., white oak. In Burns, R. M. and B. H. Honkala (tech. coord.). Silvics of North America. Vol 2. Hardwoods. Agriculture Handbook 654. USDA For. Ser., Washington, DC.

Romme, W. H., and Martin, W. M. 1982. Natural disturbance by tree-falls in an old-growth mixed mesophytic forest: Lilly Cornett Woods, Kentucky. In Muller, R. N., ed. Proceedings, $4^{\text {th }}$ Central Hardwood Forest Conference, Univ. of Kentucky, Lexington, KY. pp. 367-383.

Runkle, J. R. 1982. Patterns of disturbance in some old-growth mesic forests of the eastern United States. Ecology 63: 1533-1546.

Runkle, J. R. 1985. Disturbance regimes in temperate forests. Chapter 2 In Pickett, S. T. A. and P. S. White, eds. The ecology of natural disturbance and patch dynamics. Academic Press, New York, NY.

Runkle, J. R. 1990. Gap dynamics in an Ohio Acer-Fagus forest and speculations on the geography of disturbance. Can. J. For. Res. 20: 632-641. 
Runkle, J. R. 1992. Guidelines and sample protocol for sampling forest gaps. USDA For. Ser. Gen. Tech. Rep. PNW-283.

Runkle, J. R. 2000. Canopy tree turnover in old-growth mesic forests of eastern United States. Ecology 81: 554-567.

Russell, E. W. B. 1981. Vegetation of northern New Jersey before European settlement. Am. Mid. Nat. 105: 1-12.

Ryan, M. and B. Yoder. 1997. Hydraulic limits to tree height and tree growth: what keeps trees from growing beyond a certain height? BioScience 47: 235B242.

Sander, I. L. 1990. Quercus rubra L., northern red oak. In Burns, R. M. and B. H. Honkala (tech. coord.). Silvics of North America. Vol 2. Hardwoods. Agriculture Handbook 654. USDA For. Ser., Washington, DC.

Savill, P. S. 1991. The silviculture of trees used in British forestry. C.A.B. International, Wallingford, U.K.

Schmelz, D. V. and A. A. Lindsay. 1965. Size-class structure of old-growth forests in Indiana. For. Sci. 11:731-743.

Sear, P. B. 1926. The natural vegetation of Ohio. Ohio Journal Science 25: 139-149.

Smith, E. C. 1920. A history of Lewis County, West Virginia. self-pub., Morgantown Printing and Binding Co., Morgantown, WV.

Smith, D. M., B. G. Larson, M. J. Kelty, and P. M. S. Ashton. 1997. The practice of silviculture: applied forest ecology. John Wiley \& Sons, New York, NY.

Smith, K. T. and E. K. Sutherland. 1999. Fire-scar formation and compartmentalization in oak. Can. J. For. Res. 29: 166-171.

Spetich, M. A., S. R. Shifley, and G. R. Parker. 1999. Regional distribution and dynamics of coarse woody debris in midwestern old-growth forests. For. Sci. 45: 302-313.

Sprugel, D. G. 1991. Disturbance, equilibrium, and environmental variability: what is 'natural' vegetation in a changing environment? Biological Conservation 58: 1-18.

Stokes, M. A., and Smiley, T. L. 1968. An introduction to tree-ring dating. Univ. Arizona Press, Tuscon, AZ.

Sutherland, E. K. 1997. History of fire in a southern Ohio second-growth mixed oak forest. Pp. 172-183 In. Pallardy, S. G., R. A. Cecich, H. G. Garrett, and P. S. Johnson, eds. Proc. $11^{\text {th }}$ central hardwood forest conference. University of Missouri, Columbia, MO. 
Tomlinson, P. T., R. E. Dickson, and J. G. Isebrands. 1991. Acropetal leaf differentiation in Quercus rubra (Fagaceae). Am. J. Botany. 78: 1570-1575.

Trimble, G. R., Jr. 1969. Diameter growth of individual hardwood trees. USDA For. Ser. Res. Pap. NE-145.

Trimble, G. R, Jr. 1975. Summaries of some silvical characteristics of several Appalachian hardwood species. USDA For. Ser. Gen. Tech. Rep. NE-16.

Tyrrell, L. E., G. J. Nowacki, T. R. Crow, D. S. Buckley, E. A. Nauertz, J. N. Niese, J. L. Rollinger, and J. C. Zasada. 1998. Information about old-growth for selected forest type groups in the eastern United States. USDA For. Ser. Gen. Tech. Rep. NC-197.

USDA, 1980. Soil survey of Harrison and Taylor Counties, West Virginia. USDA Natural Resources Conservation Service, Washington, DC.

USDA, 1981. Soil survey of Belmont County, Ohio. USDA Natural Resources Conservation Service, Washington, DC.

USDA, 1983. Soil survey of Greene and Washington Counties, Pennsylvania. USDA Natural Resources Conservation Service, Washington, DC.

USDA, 1986. Soil survey of Ritchie County, West Virginia. USDA Natural Resources Conservation Service, Washington, DC.

USDA, 1995. Soil survey of Lewis County, West Virginia. USDA Natural Resources Conservation Service, Washington, DC.

Valverde, T. and J. Silvertown. 1997. Canopy closure rate and forest structure. Ecology 78: 1555-1562.

Van Lear, D. H. and T. A. Waldrop. 1989. History, uses, and effects of fire in the Appalachians. USDA For. Ser. Gen. Tech. Rep. SE-54.

Waring, R. H. 1987. Characteristics of trees predisposed to die. BioScience 37: 569-574.

Waring, R. H. and S. W. Running. 1998. Forest ecosystems: analysis at multiple scales. Academic Press, San Diego, CA.

Weitzman, S. and G. R. Trimble. 1957. Some natural factors that govern the management of oak. USDA For. Ser. Pap. No. 88.

Whitmore, T. C. 1989. Canopy gaps and the two major groups of forest trees. Ecology 70: 536538. 
Whitney, G. G. 1987. Some reflections on the value of old-growth forests, scientific and otherwise. Natural Areas Journal 7: 92 B99.

Young, T. P. and S. P. Hubbell. 1991. Crown asymmetry, treefalls, and repeat disturbance in a broad-leaved forest. Ecology 72: 1464-1471.

Young, T. P. and V. Perkocha. 1994. Treefalls, crown asymmetry, and buttresses. J. Ecology 82: 319-324. 
Table 4.1. Percent of $4500 \mathrm{~m}^{2}$ plot area represented by crown area of cored canopy trees, and percent canopy basal area represented by cored canopy trees.

\begin{tabular}{lcccccccccccc}
\hline \multicolumn{1}{c}{ Site } & \multicolumn{2}{c}{ oaks } & \multicolumn{3}{c}{ maples } & \multicolumn{1}{c}{ beech } & \multicolumn{1}{c}{ hickories } & \multicolumn{3}{c}{ total-all trees } \\
& \%crown & \%BA & \%crown & \%BA & \%crown & \%BA & \%crown & \%BA & \%crown & $\% \mathrm{BA}$ & $\mathrm{n}$ \\
\hline Colllins Woods1 & 23 & 38 & 19 & 18 & 12 & 9 & -- & 0 & 62 & 75 & 27 \\
Collins Woods2 & 27 & 32 & 16 & 12 & 7 & 6 & 2 & 2 & 52 & 55 & 26 \\
Wrights Woods1 $^{2}$ & 28 & 30 & 35 & 18 & -- & 0 & -- & 0 & 68 & 56 & 27 \\
Wrights Woods2 $^{1}$ & 25 & 50 & 40 & 20 & -- & 0 & -- & 0 & 65 & 76 & 33 \\
Watter Smith & 57 & 51 & 13 & 5 & 4 & 2 & -- & 0 & 85 & 64 & 38 \\
Murphy Tract1 & 57 & 53 & 1 & 3 & 6 & 2 & 1 & 0 & 69 & 60 & 41 \\
Murphy Tract2 & 46 & 51 & 2 & 11 & 1 & 1 & -- & 0 & 49 & 63 & 35 \\
Horners Woods1 & 58 & 47 & 15 & 5 & 7 & 2 & 2 & 1 & 86 & 56 & 38 \\
Horners Woods2 & 34 & 41 & 3 & 2 & 17 & 9 & 4 & 2 & 78 & 65 & 42 \\
\hline \multicolumn{1}{c}{ Average } & 39 & 44 & 16 & 10 & 8 & 3 & 2 & 1 & 68 & 63 & 34 \\
\hline
\end{tabular}

${ }^{1}$ plot area $5400 \mathrm{~m}^{2}$

Table 4.2. Summary statistics from COFECHA evaluation of cross-dating of individual oak increment cores.

\begin{tabular}{lccccccc}
\hline \multicolumn{1}{c}{$\begin{array}{c}\text { Site/ } \\
\text { plot }\end{array}$} & $\begin{array}{c}\text { Number } \\
\text { cores }\end{array}$ & $\begin{array}{c}\text { Number } \\
\text { segments }\end{array}$ & $\begin{array}{c}\text { Period } \\
\text { validated }\end{array}$ & $\begin{array}{c}\text { Correlation } \\
\text { with master }\end{array}$ & $\begin{array}{c}\text { Number } \\
\text { "B" flags }\end{array}$ & $\begin{array}{c}\text { Mean } \\
\text { sensitivity }\end{array}$ & $\begin{array}{c}\text { Auto- } \\
\text { correlation }\end{array}$ \\
\hline Colllins Woods $^{1}$ & 32 & 222 & $1631-1999$ & 0.555 & 21 & 0.218 & 0.749 \\
Wrights Woods $^{1}$ & 28 & 247 & $1647-1998$ & 0.590 & 17 & 0.236 & 0.661 \\
Watter Smith & 42 & 216 & $1695-1999$ & 0.581 & 23 & 0.235 & 0.758 \\
Murphy Tract1 & 60 & 347 & $1649-1998$ & 0.612 & 9 & 0.227 & 0.782 \\
Murphy Tract2 & 52 & 379 & $1652-1998$ & 0.693 & 23 & 0.248 & 0.724 \\
Horners Woods1 & 52 & 315 & $1659-1998$ & 0.548 & 27 & 0.226 & 0.751 \\
Horners Woods2 & 35 & 177 & $1621-1998$ & 0.581 & 6 & 0.215 & 0.720 \\
\hline \multicolumn{1}{c}{ Average } & 43 & 272 & -- & 0.594 & 17 & 0.229 & 0.735 \\
\hline
\end{tabular}

${ }^{1}$ Cores from plots at Collin's Woods and Wright's Woods were analyzed in single sets. 
Table 4.3. Summary site characteristics for five oak-dominated old-growth sites in Ohio, Pennsylvania, and West Virginia.

\begin{tabular}{|c|c|c|c|c|c|c|c|c|c|c|c|c|c|}
\hline \multirow[b]{2}{*}{ Site } & \multicolumn{5}{|c|}{ Overstory $(\mathrm{dbh} \geq 15 \mathrm{~cm})$} & \multicolumn{2}{|c|}{ Understory } & \multicolumn{2}{|c|}{ Seedling } & \multicolumn{4}{|c|}{ Study plot } \\
\hline & $\begin{array}{l}\text { ave. dbh } \\
(\mathrm{cm})\end{array}$ & $\begin{array}{c}\text { ave. crown } \\
\left(\mathrm{m}^{2}\right)\end{array}$ & $\begin{array}{l}\text { ave. ht. } \\
\text { (m) }\end{array}$ & ${ }^{1} \mathrm{~S}$ & ${ }^{2} \mathrm{H}^{\prime}$ & $\mathrm{S}$ & $\mathrm{H}^{\prime}$ & $\mathrm{S}$ & $\mathrm{H}^{\prime}$ & $\begin{array}{l}\text { Elev. } \\
(\mathrm{m})\end{array}$ & $\begin{array}{c}\text { Slope } \\
\% \\
\end{array}$ & Aspect & $\begin{array}{c}\text { Slope } \\
\text { Position }^{3}\end{array}$ \\
\hline Collins Woods 1 & 52.1 & 72.3 & 30.0 & 9 & 1.7 & 7 & 0.9 & 9 & 1.4 & 340 & 20 & WNW & US \\
\hline Collins Woods2 & 44.9 & 53.9 & 26.4 & 10 & 2.0 & 7 & 1.1 & & & 340 & 22 & WNW & US \\
\hline Wrights Woods 1 & 36.8 & 74.6 & 25.1 & 6 & 1.4 & 7 & 0.8 & 13 & 0.7 & 320 & 19 & $\mathrm{~N}$ & LS \\
\hline Wrights Woods2 & 37.7 & 64.3 & 23.2 & 7 & 1.5 & 8 & 0.6 & 13 & 0.4 & 320 & 22 & NW & LS \\
\hline Watter Smith & 40.0 & 67.3 & 25.8 & 15 & 2.4 & 16 & 2.1 & 19 & 0.8 & 340 & 35 & SW & MS \\
\hline Horners Woods1 & 33.0 & 60.7 & 26.3 & 13 & 2.3 & 9 & 1.5 & 17 & 0.7 & 400 & 36 & NW & MS \\
\hline Horners Woods2 & 35.0 & 56.2 & 24.7 & 12 & 2.2 & 12 & 1.7 & 15 & 0.6 & 400 & 35 & NW & MS \\
\hline Murphy Tract1 & 34.1 & 56.2 & 21.1 & 12 & 2.1 & 11 & 1.9 & 16 & 0.4 & 305 & 21 & NW & US \\
\hline Murphy Tract2 & 30.2 & 43.6 & 20.1 & 11 & 1.9 & 18 & 2.0 & 18 & 0.6 & 300 & 25 & $\mathrm{~W}$ & US \\
\hline Average & 38.2 & 61.0 & 24.7 & 11 & 1.9 & 11 & 1.4 & 15 & 0.7 & 341 & 26 & & \\
\hline
\end{tabular}

${ }^{1} \mathrm{~S}=$ number of species found

${ }^{2} \mathrm{H}^{\prime}=$ Shannon-Weiner diversity index

${ }^{3}$ Slope Position: US=upper slope, MS = midslope, $\mathrm{LS}=$ lower slope 
Table 4.4 Importance values $\left(\mathrm{IV}^{1}\right.$, maximum $\left.=100\right)$, basal area $\left(\mathrm{m}^{2} \mathrm{ha}^{-1}\right)$ and abundance $(\mathrm{tph})$ for overstory tree species $(\mathrm{dbh} \geq 15 \mathrm{~cm})$ at five oak-dominated sites old-growth sites in Ohio, Pennsylvania, and West Virginia. Some rare species omitted.

\begin{tabular}{|c|c|c|c|c|c|c|c|c|c|c|c|c|c|c|c|c|c|c|c|c|c|c|c|c|c|c|c|}
\hline \multirow{2}{*}{ Species } & \multicolumn{3}{|c|}{ CW1 } & \multicolumn{3}{|c|}{ CW2 } & \multicolumn{3}{|c|}{ WW1 } & \multicolumn{3}{|c|}{ WW2 } & \multicolumn{3}{|c|}{ WS } & \multicolumn{3}{|c|}{ MT1 } & \multicolumn{3}{|c|}{$\overline{\text { MT2 }}$} & \multicolumn{3}{|c|}{ HW1 } & \multicolumn{3}{|c|}{ HW2 } \\
\hline & IV & $\mathrm{BAh}$ & tph & IV & BAh & tph & IV & BAh & tph & IV & BAh & tph & IV & BAh & tph & IV & BAh & tph & IV & BAh & tph & IV & BAh & tph & IV & BAh & tph \\
\hline Acerub & 3 & 1.0 & 4 & 12 & 3.2 & 19 & 21 & 3.8 & 47 & 9 & 1.5 & 19 & 14 & 3.3 & 33 & 12 & 3.0 & 38 & 17 & 3.0 & 71 & 11 & 1.6 & 36 & 14 & 3.4 & 40 \\
\hline Acesac & 45 & 16.3 & 87 & 23 & 4.7 & 53 & 47 & 12.0 & 122 & 51 & 11.3 & 143 & 10 & 2.0 & 22 & 2 & 0.1 & 4 & & & & 15 & 2.7 & 49 & 6 & 0.7 & 18 \\
\hline Carspp. & & & & 4 & 1.0 & 6 & & & & & & & 8 & 2.1 & 20 & 6 & 1.1 & 18 & 2 & 0.3 & 7 & 12 & 2.1 & 38 & 8 & 1.2 & 22 \\
\hline Faggra & 21 & 5.3 & 49 & 23 & 7.2 & 47 & & & & & & & 12 & 2.0 & 36 & 18 & 4.2 & 73 & 10 & 1.6 & 38 & 13 & 2.1 & 44 & 24 & 6.0 & 64 \\
\hline Fraame & & & & & & & 1 & 0.1 & 2 & & & & 8 & 2.5 & 16 & & & & & & & 1 & 0.1 & 2 & & & \\
\hline Lirtul & 10 & 4.5 & 13 & 6 & 2.7 & 6 & & & & & & & 2 & 0.3 & 4 & & & & & & & & & & 7 & 3.3 & 9 \\
\hline Magacu & & & & & & & & & & & & & & & & 1 & 0.1 & 2 & & & & 3 & 0.6 & 7 & 3 & 0.3 & 7 \\
\hline Nyssyl & & & & & & & & & & & & & 1 & 0.2 & 2 & 4 & 0.7 & 13 & 3 & 0.4 & 9 & 4 & 1.1 & 9 & 3 & 0.6 & 7 \\
\hline Oxyarb & & & & 2 & 0.4 & 4 & & & & & & & & & & 7 & 0.6 & 20 & 8 & 0.7 & 29 & 2 & 0.3 & 7 & 2 & 0.2 & 4 \\
\hline Pruser & 1 & 0.1 & 2 & & & & 11 & 2.8 & 16 & 11 & 2.8 & 19 & & & & & & & & & & & & & & & \\
\hline Quealb & 6 & 3.7 & 4 & 14 & 9.2 & 13 & 19 & 10.2 & 18 & 11 & 6.3 & 9 & 14 & 7.3 & 20 & 20 & 9.3 & 44 & 37 & 15.6 & 102 & 13 & 6.0 & 22 & 7 & 3.5 & 9 \\
\hline Quecoc & & & & & & & & & & & & & & & & & & & 4 & 1.4 & 7 & & & & & & \\
\hline Quepri & & & & & & & & & & & & & 4 & 1.6 & 7 & & & & 10 & 3.2 & 24 & 11 & 5.3 & 18 & 4 & 0.5 & 9 \\
\hline Querub & 7 & 4.2 & 7 & 9 & 6.0 & 9 & & & & 10 & 5.2 & 9 & 16 & 8.5 & 24 & 11 & 5.6 & 20 & 2 & 0.7 & 4 & 1 & 0.5 & 2 & & & \\
\hline Quevel & & & & & & & & & & & & & 7 & 2.5 & 13 & 19 & 8.8 & 56 & 6 & 2.1 & 11 & 15 & 7.3 & 24 & 19 & 8.1 & 29 \\
\hline Ulmspp. & 6 & 3.0 & 7 & 7 & 1.5 & 10 & 1 & 0.3 & 2 & 7 & 1.4 & 13 & & & & & & & & & & & & & & & \\
\hline Totals & 98 & 38 & 173 & 99 & 36 & 167 & 100 & 29 & 207 & 99 & 29 & 211 & 95 & 32 & 198 & 100 & 34 & 289 & 100 & 29 & 302 & 100 & 30 & 258 & 97 & 28 & 218 \\
\hline$\%$ oaks & 13 & 21 & 6 & 23 & 42 & 13 & 19 & 35 & 9 & 21 & 40 & 9 & 43 & 62 & 33 & 51 & 71 & 42 & 59 & 79 & 49 & 40 & 64 & 26 & 31 & 44 & 21 \\
\hline
\end{tabular}

${ }^{1} \mathrm{IV}=($ relative basal area + relative abundance + relative frequency $) / 3$ 
Table 4.5 Importance values $\left(\mathrm{IV}^{1}\right.$, maximum $\left.=100\right)$ and abundance $(\mathrm{tph})$ for understory tree species $(15 \mathrm{~cm}>\mathrm{dbh}>2.5 \mathrm{~cm})$ at five oak-dominated old-growth forests in Ohio, West Virginia, and Pennsylvania. Some rare species are omitted.

\begin{tabular}{|c|c|c|c|c|c|c|c|c|c|c|c|c|c|c|c|c|c|c|}
\hline \multirow{2}{*}{ Species } & \multicolumn{2}{|c|}{ CW1 } & \multicolumn{2}{|c|}{ CW2 } & \multicolumn{2}{|c|}{ WW1 } & \multicolumn{2}{|c|}{ WW2 } & \multicolumn{2}{|c|}{ WS } & \multicolumn{2}{|c|}{ MT1 } & \multicolumn{2}{|c|}{ MT2 } & \multicolumn{2}{|c|}{ HW 1} & \multicolumn{2}{|c|}{ HW2 } \\
\hline & IV & tph & IV & tph & IV & tph & IV & tph & IV & tph & IV & $\mathrm{tph}$ & IV & $\mathrm{tph}$ & IV & $\mathrm{tph}$ & IV & tph \\
\hline Acerub & & & 6 & 23 & 4 & 4 & 15 & 37 & 11 & 64 & 26 & 171 & 35 & 322 & 6 & 16 & 12 & 76 \\
\hline Acesac & 79 & 666 & 67 & 563 & 87 & 182 & 72 & 237 & 15 & 122 & 3 & 16 & 2 & 13 & 50 & 276 & 25 & 2 \\
\hline Amearb & & & & & & & & & 1 & 4 & 7 & 24 & 5 & 29 & & & 1 & 2 \\
\hline Carcar & & & & & 2 & 2 & 2 & 4 & 3 & 18 & & & 1 & & & & & \\
\hline Carspp. & 4 & 11 & 5 & 19 & 2 & 2 & 1 & 2 & 2 & 4 & 3 & 9 & 1 & 7 & 4 & 7 & 1 & 2 \\
\hline Corflo & 1 & 2 & & & 2 & 2 & & & 4 & 20 & 11 & 58 & 7 & 42 & 7 & 18 & 3 & 18 \\
\hline Faggra & 7 & 24 & 11 & 32 & & & & & 25 & 176 & 32 & 193 & 21 & 182 & 23 & 102 & 39 & 384 \\
\hline Fraame & 2 & 2 & 1 & 2 & & & & & 1 & 2 & & & 1 & 4 & & & 2 & 7 \\
\hline Magacu & & & & & & & & & & & 2 & 11 & 1 & 4 & & & & \\
\hline Nyssyl & & & & & & & & & 1 & 2 & 3 & 20 & 3 & 18 & & & 6 & 29 \\
\hline Ostvir & 5 & 11 & 9 & 25 & & & 2 & 6 & 24 & 184 & & & 2 & 9 & 7 & 20 & 1 & 2 \\
\hline Oxyarb & & & & & & & & & 1 & 2 & 10 & 31 & 14 & 76 & 1 & 2 & 3 & 13 \\
\hline Pruser & 2 & 4 & 1 & 2 & 2 & 2 & 1 & 2 & & & & & & & & & & \\
\hline Quealb & & & & & & & & & & & 2 & 4 & 6 & 24 & & & & \\
\hline Quecoc & & & & & & & & & & & & & 1 & 2 & & & & \\
\hline Quepri & & & & & & & & & & & & & 1 & 4 & 2 & 4 & & \\
\hline Sasalb & & & & & & & & & 1 & 2 & & & & & & & & \\
\hline Tilame & & & & & & & 6 & 13 & 1 & 2 & & & & & & & 1 & 2 \\
\hline Ulmspp. & & & & & 2 & 2 & 1 & 2 & 4 & 16 & & & 1 & 2 & & & & \\
\hline Totals & 100 & 721 & 100 & 667 & 100 & 198 & 100 & 302 & 93 & 620 & 100 & 538 & 99 & 740 & 100 & 444 & 93 & 538 \\
\hline$\%$ oaks & 0.0 & 0.0 & 0.0 & 0.0 & 0.0 & 0.0 & 0.0 & 0.0 & 0.0 & 0.0 & 2.1 & 0.8 & 8.1 & 4.2 & 2.0 & 1.0 & 0.0 & 0.0 \\
\hline
\end{tabular}

${ }^{1} \mathrm{IV}=($ Rel. basal area + rel. abundance + rel. frequency $) / 3$ 
Table 4.6. Seedling density ( stems $\mathrm{ha}^{-1}$ ) of woody species from nine oak-dominated old-growth stands in West Virginia, Pennsylvania, and Ohio. (Total seedlings/ha $=$ plot tally*10,000/160.)

\begin{tabular}{|c|c|c|c|c|c|c|c|c|c|c|c|c|c|c|c|c|c|c|}
\hline \multirow{2}{*}{ Species } & \multicolumn{2}{|c|}{$\mathrm{CW}^{3}$} & \multicolumn{2}{|c|}{$\overline{W W 1}$} & \multicolumn{2}{|c|}{ WW2 } & \multicolumn{2}{|c|}{ WS 1} & \multicolumn{2}{|c|}{ MT1 } & \multicolumn{2}{|c|}{ MT2 } & \multicolumn{2}{|c|}{ HW1 } & \multicolumn{2}{|c|}{ HW2 } & \multicolumn{2}{|c|}{ Average } \\
\hline & $\mathrm{Sm}$ & Lar & $\mathrm{Sm}$ & Lar & $\mathrm{Sm}$ & Lar & $\mathrm{Sm}$ & Lar & $\mathrm{Sm}^{1}$ & Lar $^{2}$ & $\mathrm{Sm}$ & Lar & $\mathrm{Sm}$ & Lar & $\mathrm{Sm}$ & Lar & $\mathrm{Sm}$ & Lar \\
\hline Acerub & & & 625 & & 313 & & 7500 & 63 & 44938 & 313 & 21688 & 313 & 11500 & & 16875 & & 12930 & 86 \\
\hline Acesac & 3201 & 1190 & 4875 & 938 & 23021 & 1615 & 563 & 250 & 125 & & 125 & & 4313 & 375 & 1563 & 125 & 4723 & 562 \\
\hline Aesoct & & & & & & & 63 & 125 & & & & & & & & & 8 & 16 \\
\hline Amearb & 26 & 53 & & & & & 313 & & 7688 & 563 & 4813 & 563 & 625 & & & & 1683 & 147 \\
\hline Asitri & & & & & & & & & & & & & 125 & 63 & & & 16 & 8 \\
\hline Betlen & & & & & & & & & & & & & & & 2250 & 125 & 281 & 16 \\
\hline Cargla & & & & & & & 125 & & 125 & & 375 & 63 & 375 & & & & 125 & 8 \\
\hline Carcor & 556 & 26 & & & & & & & 0 & & & & & & & & 69 & 3 \\
\hline Carova & & & 375 & & 208 & & 500 & & 125 & & 313 & 63 & & & & & 190 & 8 \\
\hline Cartom & & & 63 & & 729 & & 125 & & & & & & 63 & & & & 122 & 0 \\
\hline Casden & & & & & & & 63 & & & & & & 125 & & 63 & & 31 & 0 \\
\hline Corflo & & & & & & & & & 125 & 188 & 125 & 63 & & & & & 31 & 31 \\
\hline Faggra & 106 & 132 & & & & & 250 & 63 & 1625 & 1063 & 438 & 688 & 563 & 188 & 438 & 1125 & 427 & 407 \\
\hline Fraame & 1349 & 159 & 688 & 188 & 208 & & 3625 & 250 & 438 & 250 & 500 & & 1188 & 125 & 1625 & 125 & 1203 & 137 \\
\hline Hamvir & & & & & & & & & & & 563 & 63 & & & & & 70 & 8 \\
\hline Linben & & & 4063 & 3813 & 781 & 365 & 875 & 813 & & & & & & & 688 & & 801 & 624 \\
\hline Lirtul & & & & & & & 375 & 63 & 688 & & 750 & & 2563 & & 3250 & & 953 & 8 \\
\hline Magacu & & & & & & & & & & & 375 & & 313 & 63 & 250 & & 117 & 8 \\
\hline Nyssyl & 26 & & & & & & 1000 & 63 & 2875 & 125 & 750 & 63 & 188 & & 2375 & & 902 & 31 \\
\hline Ostvir & & 26 & & & 156 & & 2750 & 438 & & & 875 & 375 & 1000 & 563 & & & 598 & 175 \\
\hline Oxyarb & & & & & & & & & 438 & 250 & 500 & & 750 & 563 & 438 & & 266 & 102 \\
\hline Pruser & & 26 & 750 & 63 & 750 & & 563 & 63 & 1063 & & 250 & & 438 & & 125 & & 492 & 19 \\
\hline Quealb & & & 875 & & 313 & & 938 & & 1375 & 63 & 6875 & 188 & 1625 & & 125 & & 1516 & 31 \\
\hline Quecoc & & & & & & & & & & & 63 & & & & & & 8 & 0 \\
\hline Quepri & & & & & & & 688 & & & & 375 & & 2125 & & 188 & & 422 & 0 \\
\hline Querub & & & 438 & 188 & 365 & 63 & 188 & & 63 & & & & 125 & & & & 147 & 31 \\
\hline Quevel & & & & & & & & & 438 & & 563 & 188 & & & 63 & & 133 & 23 \\
\hline Ulmspp & 3201 & 26 & 750 & & 417 & 125 & 188 & 63 & & & & & & & & & 569 & 27 \\
\hline Sasalb & & & 63 & & 52 & & 125 & & 313 & & 625 & & & & 63 & & 155 & 0 \\
\hline Tilame & & & & & 313 & & & & & & & & & & & & 39 & 0 \\
\hline TOTALS & 8466 & 1640 & 13563 & 5188 & 27626 & 2168 & 20813 & 2250 & 62438 & 2813 & 40938 & 2625 & 28000 & 1938 & 30375 & 1500 & & \\
\hline
\end{tabular}

${ }^{1}$ Small $=<1 \mathrm{~m}$ tall

${ }^{2}$ Large $=<2.5 \mathrm{~cm} \mathrm{dbh},>1 \mathrm{~m}$ tall

${ }^{3}$ Collin's Woods regeneration is pooled, derived from an earlier study by (Hicks 1998). 
Table 4.7. Q-factors calculated from the ratio of the numbers of stems present in two consecutive size-classes, for nine old-growth study plots.

\begin{tabular}{lccccccccc}
\hline dbh-class & CW1 & CW2 & WW1 & WW2 & WSSP & MT1 & MT2 & HW1 & HW2 \\
\hline 5 & 9.2 & 2.9 & 5.0 & 3.7 & 4.6 & 2.9 & 2.3 & 2.8 & 2.5 \\
10 & 3.9 & 3.2 & 1.0 & 1.8 & 2.2 & 1.1 & 1.4 & 1.7 & 2.5 \\
15 & 1.3 & 5.2 & 1.2 & 1.0 & 1.2 & 2.2 & 1.5 & 1.2 & 2.3 \\
20 & 2.3 & 0.5 & 1.1 & 1.7 & 3.8 & 1.3 & 2.2 & 1.4 & 0.5 \\
25 & 0.8 & 1.2 & 0.8 & 0.7 & 0.6 & 1.8 & 1.4 & 1.5 & 2.3 \\
30 & 1.0 & 1.1 & 1.8 & 1.0 & 1.3 & 1.2 & 1.1 & 1.1 & 3.8 \\
35 & 0.5 & 0.8 & 0.5 & 1.3 & 0.7 & 1.4 & 3.8 & 3.0 & 0.8 \\
40 & 2.7 & 1.0 & 2.0 & 1.1 & 1.8 & 1.8 & 0.7 & 0.7 & 1.0 \\
45 & 0.8 & 6.0 & 2.7 & 3.0 & 1.0 & 1.3 & 0.5 & 0.9 & 0.6 \\
50 & 0.3 & 0.5 & 0.5 & 2.5 & 1.0 & 0.3 & 1.0 & 1.7 & 4.5 \\
55 & 2.6 & 2.0 & 3.0 & 1.0 & 1.3 & 1.3 & 1.5 & 1.0 & 0.3 \\
60 & 1.3 & 0.5 & 2.0 & 1.0 & 2.0 & 1.2 & 0.8 & 2.0 & 2.3 \\
65 & 2.0 & 1.0 & -- & 0.5 & 0.7 & 2.0 & 1.7 & 0.4 & 3.0 \\
70 & 0.7 & 1.0 & -- & 0.5 & 1.5 & 1.0 & 0.8 & 0.4 & 1.0 \\
75 & 3.0 & 1.0 & -- & 0.5 & -- & & & 1.4 & 1.0 \\
80 & 0.5 & 0.4 & -- & 2.0 & -- & & & 2.5 & -- \\
85 & 0.7 & 5.0 & 2.0 & 0.5 & 2.0 & & & 1.0 & -- \\
90 & 3.0 & 0.5 & 0.3 & 2.0 & 2.0 & & & 1.0 & -- \\
95 & 0.3 & 2.0 & & 0.5 & & & & 1.0 & 2.0 \\
100 & 2.0 & 0.3 & & 0.7 & & & & 1.0 & \\
\hline Average & 1.9 & 1.8 & 1.7 & 1.3 & 1.7 & 1.5 & 1.5 & 1.4 & 1.9 \\
Stdev & 2.0 & 1.8 & 1.3 & 0.9 & 1.1 & 0.6 & 0.9 & 0.7 & 1.2 \\
\hline
\end{tabular}


Table 4.8. Volume $\left(\mathrm{m}^{3} / \mathrm{ha}\right)$ and basal area $\left(\mathrm{m}^{2} / \mathrm{ha}\right)$ of coarse woody debris (min.diameter $\left.=15 \mathrm{~cm}\right)$ at five oak dominated old-growth sites in West Virginia, Pennsylvania and Ohio, by type and species. "Other" includes Betula lenta, Castanea dentata, Carya spp., Fraxinus americana, Nyssa sylvatica, Ostrya virginia, Prunus aviums, P. serotina, Robinia psuedoacacia, and Sassafras albidum .

\begin{tabular}{|c|c|c|c|c|c|c|c|c|c|c|c|c|c|c|c|}
\hline Site & Type & Acespp. & Faggra & Lirtul & Oxyarb & Quealb & Quecoc & Quepri & Querub & Quevel & Quespp & Ulmspp & Unknown & Other & Totals \\
\hline \multirow{3}{*}{ WW1 } & Snap & 1.32 & & & & 25.24 & & & & & & & 0.08 & 1.60 & 28.2 \\
\hline & Tip & 3.74 & & & & 39.87 & & & & & & & 3.40 & & 47.0 \\
\hline & Snag & 0.15 & & & & 3.09 & & & & & & & & 1.26 & 4.5 \\
\hline \multirow{3}{*}{ WW2 } & Snap & 1.06 & & & & 59.29 & & & 5.04 & & & 0.33 & 0.32 & 9.60 & 75.6 \\
\hline & Tip & & & & & 11.22 & & & & & & & 0.31 & & 11.5 \\
\hline & Snag & 0.83 & & & & 1.06 & & & 1.22 & & & 0.42 & & 0.56 & 4.1 \\
\hline \multirow{3}{*}{ MT1 } & Snap & 1.30 & 2.94 & & 0.43 & 8.85 & 5.25 & & 1.20 & 11.00 & & & 7.30 & 1.37 & 39.7 \\
\hline & Tip & & & & & 5.71 & & & & 2.34 & & & 3.42 & & 11.5 \\
\hline & Snag & 1.43 & 0.38 & & & 2.32 & & & 0.47 & & & & & & 4.6 \\
\hline \multirow{3}{*}{ MT2 } & Snap & & 0.47 & & & 16.55 & 19.27 & & & 0.48 & 7.10 & & 2.84 & & 46.7 \\
\hline & Tip & & & & & 16.84 & & & & & & & & & 16.8 \\
\hline & Snag & 0.40 & & & 0.19 & 0.31 & 1.39 & & & & & & & & 2.3 \\
\hline \multirow{3}{*}{ HW1 } & Snap & 0.08 & & & & 1.34 & & & & 28.32 & 2.03 & & 10.18 & & 42.0 \\
\hline & Tip & & 0.25 & & & 5.45 & & 11.68 & 1.87 & & 1.34 & & 25.53 & & 46.1 \\
\hline & Snag & 0.52 & 0.02 & & 0.15 & 1.01 & & 0.21 & & & & & & & 1.9 \\
\hline \multirow{3}{*}{ HW2 } & Snap & & 6.22 & & & 9.39 & & 4.76 & & 11.90 & 1.70 & & 10.18 & & 44.1 \\
\hline & Tip & & & & & 11.22 & & & & 44.56 & 2.72 & & 1.02 & & 59.5 \\
\hline & Snag & & 1.35 & & 0.18 & 0.76 & & 0.93 & & & & & & 0.12 & 3.3 \\
\hline \multirow{3}{*}{ WS } & Snap & 1.61 & & & & 16.39 & & & 26.27 & & & & 3.22 & 2.08 & 49.6 \\
\hline & Tip & & & & & 12.87 & & & & & & & 4.22 & 1.29 & 18.4 \\
\hline & Snag & 0.20 & & & & 1.46 & & & & & & & & 1.16 & 2.8 \\
\hline \multirow{3}{*}{ CW1 } & Snap & 2.92 & 14.31 & 3.18 & & 10.06 & & & 10.44 & & 3.87 & 7.31 & 10.53 & 0.00 & 62.6 \\
\hline & Tip & & & & & & & & & & & & & & \\
\hline & Snag & & 1.04 & & & 2.45 & & & & & & & & & 3.5 \\
\hline \multirow{3}{*}{ CW2 } & Snap & & 1.42 & 0.23 & & 23.26 & & & & & 0.18 & 2.02 & 1.52 & 0.18 & 28.8 \\
\hline & Tip & & & & & & & & & & & & & & \\
\hline & Snag & & 0.86 & 1.44 & & & & & & & & 0.28 & & 0.48 & 3.1 \\
\hline \multirow{3}{*}{ Average } & Snap & 0.7 & 2.8 & 0.4 & & 17.1 & 2.7 & 0.5 & 1.9 & 5.7 & 1.7 & 1.1 & 4.8 & 1.4 & 40.9 \\
\hline & Tip & 0.4 & & & & 10.0 & & 1.3 & 0.2 & 5.2 & 0.5 & & 3.7 & & 21.4 \\
\hline & Snag & 0.4 & 0.4 & 0.2 & & 1.2 & 0.2 & 0.1 & 0.2 & & 0.0 & 0.1 & & 0.3 & 3.0 \\
\hline
\end{tabular}


Table 4.9. Ratio of dead to live stems by $10 \mathrm{~cm}$ diameter class.

Diameter class $(\mathrm{cm})$

\begin{tabular}{lccccccccccc}
\hline \multicolumn{1}{c}{ Site } & 20 & 30 & 40 & 50 & 60 & 70 & 80 & 90 & 100 & Ave. & Stdev \\
\hline Collins Woods1 & 0.3 & 0.5 & 0.2 & 0.5 & 0.3 & 0.5 & 0.5 & 0.7 & -- & 0.4 & 0.15 \\
Collins Woods2 & 0.7 & 0.4 & 0.4 & 0.1 & 0.0 & 0.0 & 0.7 & 0.5 & -- & 0.4 & 0.29 \\
Wrights Woods1 & 0.2 & 0.3 & 0.2 & 0.3 & 0.2 & 1.0 & 1.0 & 0.4 & 2.0 & 0.6 & 0.62 \\
Wrights Woods2 & 0.2 & 0.1 & 0.2 & 0.3 & 4.0 & 1.0 & 1.0 & 0.8 & -- & 0.9 & 1.29 \\
Watter Smith & 0.3 & 0.4 & 0.1 & 0.1 & 0.3 & 0.6 & 0.0 & 0.3 & -- & 0.3 & 0.19 \\
Murphy Tract1 & 0.2 & 0.2 & 0.5 & 0.5 & 0.6 & 0.0 & 0.3 & & -- & 0.3 & 0.22 \\
Murphy Tract2 & 0.1 & 0.6 & 0.9 & 0.6 & 0.3 & -- & -- & -- & -- & 0.5 & 0.28 \\
Horners Woods1 & 0.2 & 0.6 & 0.4 & 0.6 & 0.0 & 0.6 & 0.7 & -- & -- & 0.4 & 0.25 \\
Horners Woods2 & 0.2 & 0.2 & 0.6 & 0.6 & 0.4 & 1.0 & 1.0 & -- & -- & 0.6 & 0.34 \\
\hline
\end{tabular}

Averages, by plot (Wrights Woods out $)=0.35 \pm 0.08$

Averages, by size class (Wrights Woods out) $=0.41 \pm 0.09$

Table 4.10 Canopy gap $(\mathrm{n}=21)$ summary characteristics for nine 0.45 ha study plots in five oakdominated old-growth forests in Ohio, Pennsylvania, and West Virginia.

\begin{tabular}{lccccccc}
\hline \multirow{2}{*}{ Site } & $\begin{array}{c}\text { Number } \\
\text { of } \\
\text { gaps }\end{array}$ & $\begin{array}{c}\text { Percent } \\
\text { plot } \\
\text { area }\end{array}$ & $\begin{array}{c}\text { Gap size } \\
\left(\mathrm{m}^{2}\right)\end{array}$ & $\begin{array}{c}\text { Gap age } \\
(\text { yrs. })\end{array}$ & $\begin{array}{c}\text { Maker dbh } \\
(\mathrm{cm})\end{array}$ & $\begin{array}{c}\text { Filler dbh } \\
(\mathrm{cm})\end{array}$ & Dia/Ht ${ }^{1}$ \\
\hline Collins Woods1 & 1 & 1.1 & 51 & 10 & 87.0 & 8.3 & 0.8 \\
Collins Woods2 & 3 & 4.2 & 128 & 8 & 73.0 & 14.6 & 0.4 \\
Wrights Woods1 & -4 & 5.7 & 64 & 5 & 71.6 & 7.9 & 0.3 \\
Wrights Woods2 & -- & -- & -- & -- & -- & -- & - \\
Watter Smith & 3 & 5.4 & 81 & 6 & 79.3 & 15.2 & 0.4 \\
Murphy Tract1 & 3 & 6.7 & 100 & 7 & 56.6 & 8.3 & 0.5 \\
Murphy Tract2 & 1 & 2.5 & 114 & 1 & 63.7 & 8.4 & 0.4 \\
Horners Woods1 & 3 & 4.0 & 61 & 5 & 49.4 & 19.9 & 0.4 \\
Horners Woods2 & 3 & 7.5 & 76 & 9 & 32.5 & 13.2 & 0.7 \\
\hline \multicolumn{1}{c}{ Average } & 2.6 & 4.6 & 94 & 6 & 64.1 & 12.0 & 0.5 \\
\hline
\end{tabular}

${ }^{1} \mathrm{Dia} / \mathrm{Ht}=$ ratio of largest gap diameter to height of border trees 
Figure 4.1. Location map of five oak-dominated, old growth study sites.

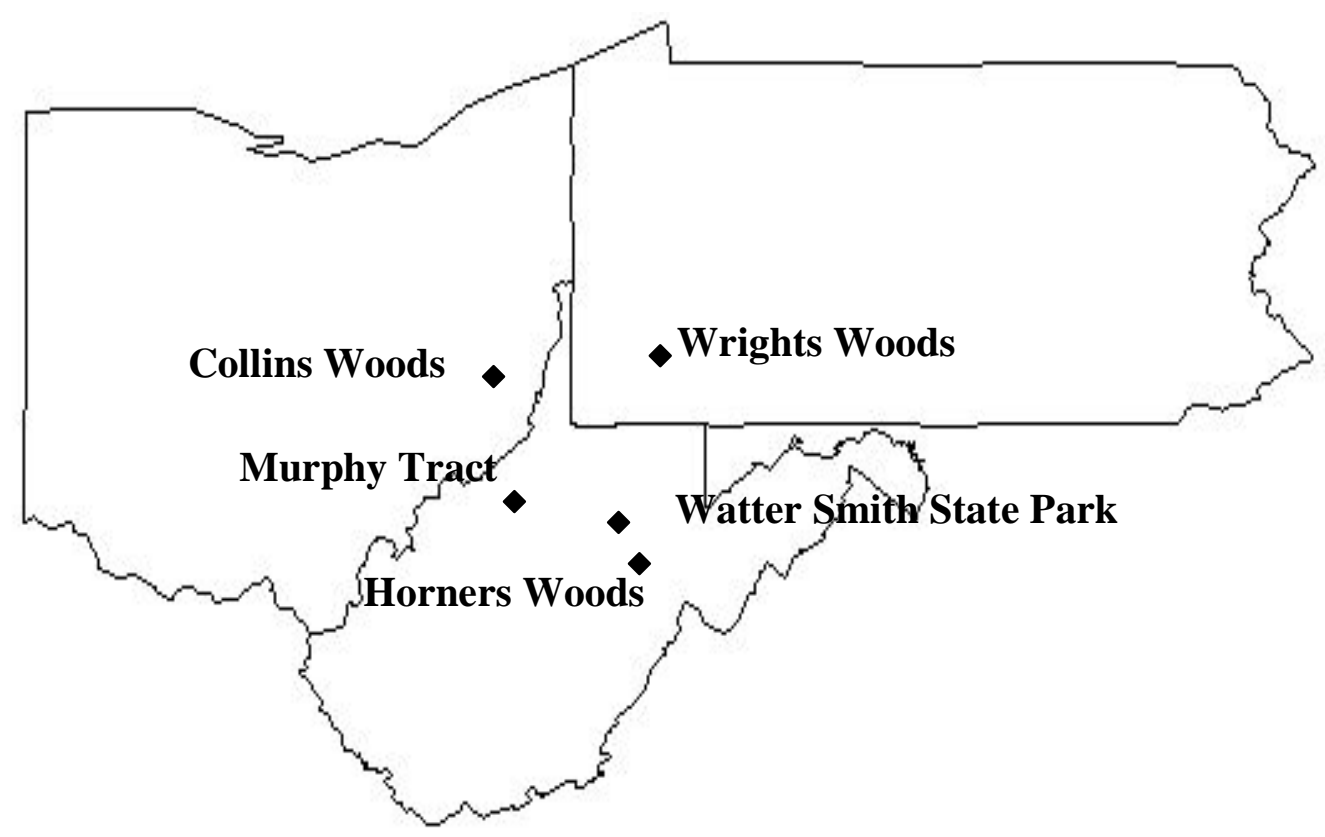


Figure 4.2. Cluster analysis of nine oak dominated old-growth study plots using species importance value. Distance measure is Euclidean distance, and clusters are linked using Ward's method.
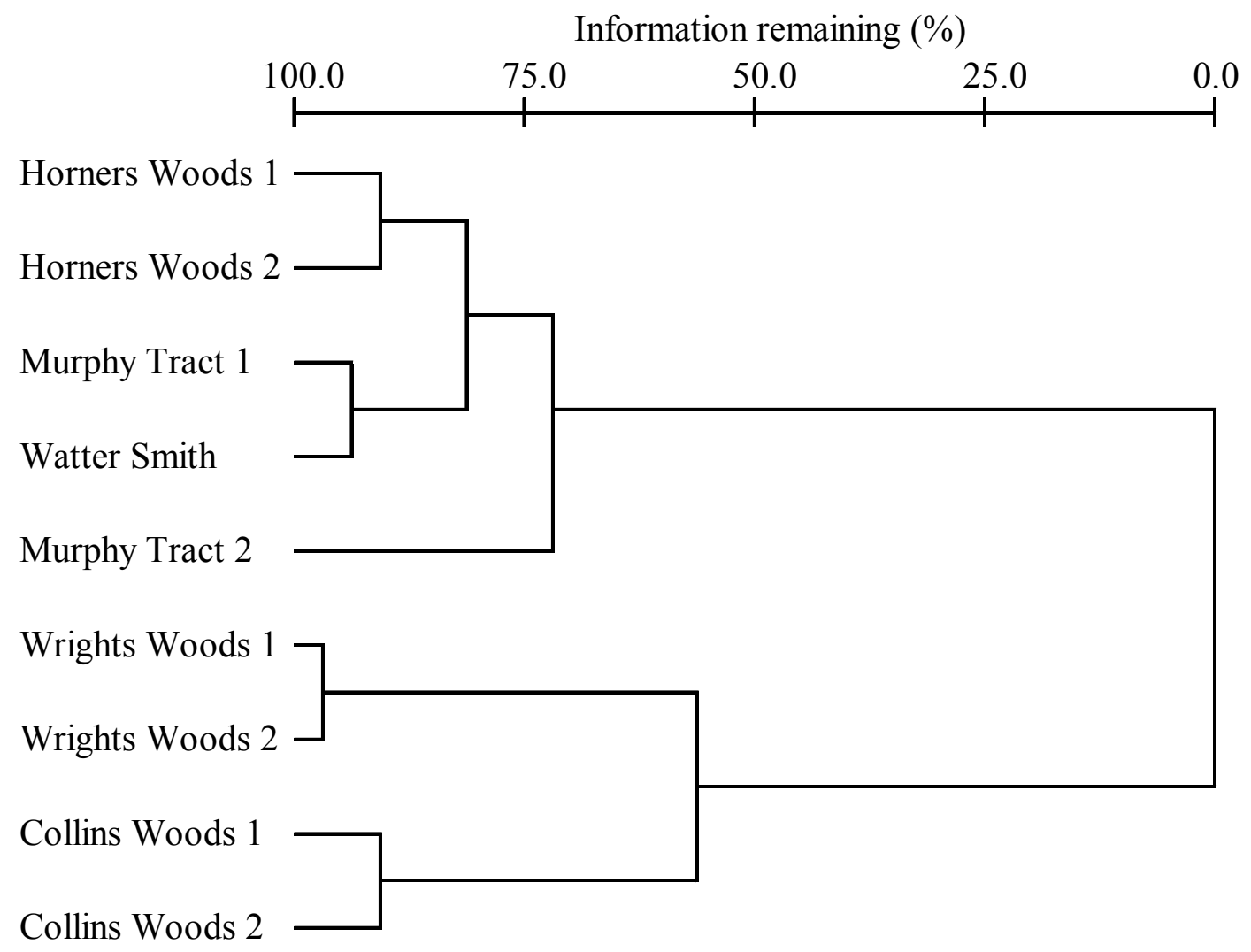

Percent chaining $=6.7 \%$ 
Figure 4.3. Detrended correspondance analysis of overstory $(\mathrm{dbh} \geq 15 \mathrm{~cm})$ and understory $(2.5 \mathrm{~cm} \leq \mathrm{dbh}<15 \mathrm{~cm})$ composition for nine study plots, by species importance value.

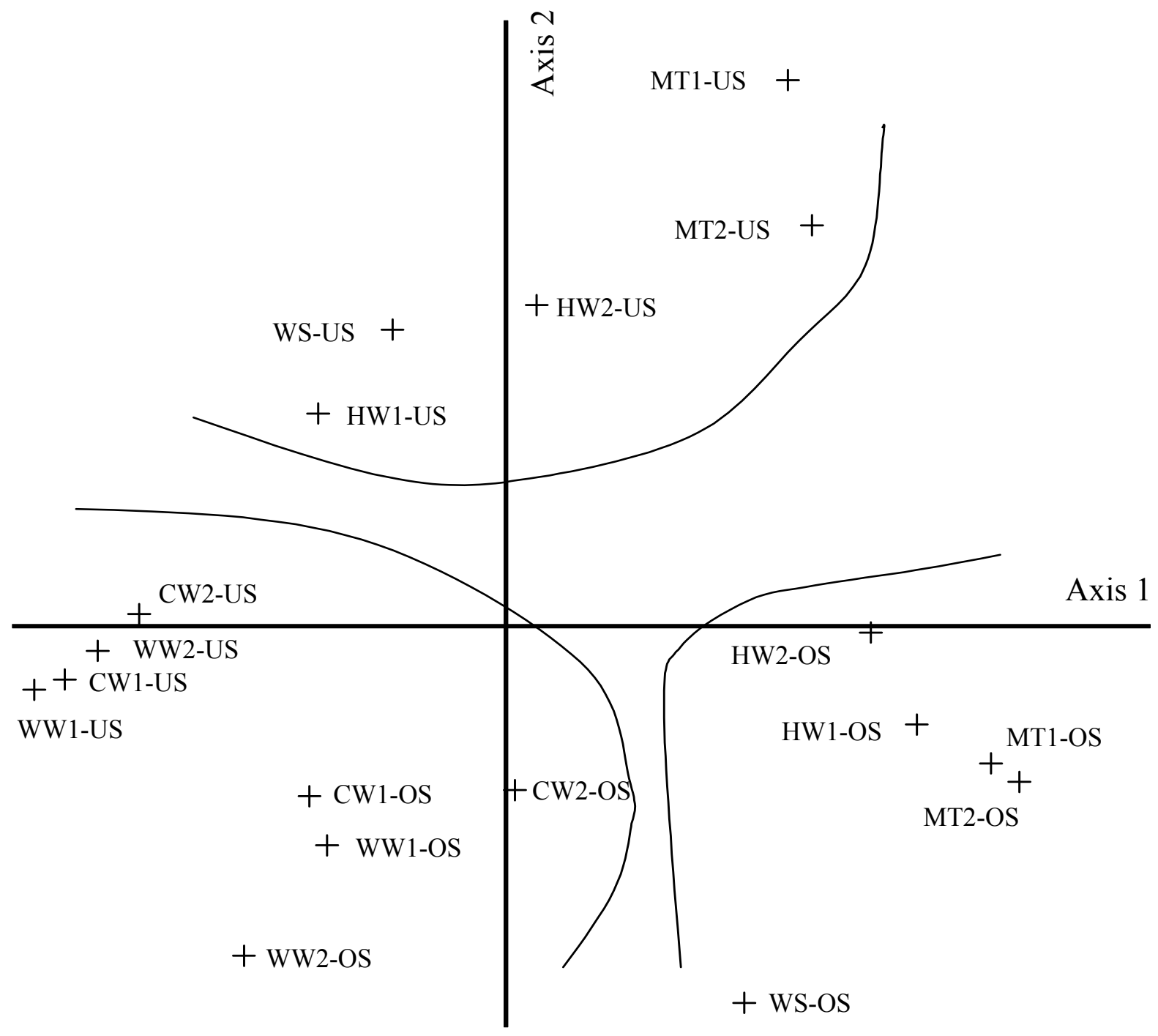


Figure 4.4 Diameter distributions of nine old-growth plots in Ohio, Pennsylvania, and West Virginia. X-axis is the midpoint of 5 $\mathrm{cm}$ diameter class. The line graph shows total stems/ha. Number of stems in the $5 \mathrm{~cm}$ diameter class is shown by the numbers in the left hand corner of the graph. The first number is total stems, the second is maple, and the third, if present, represents American beech.

\section{a) Collins Woods1}

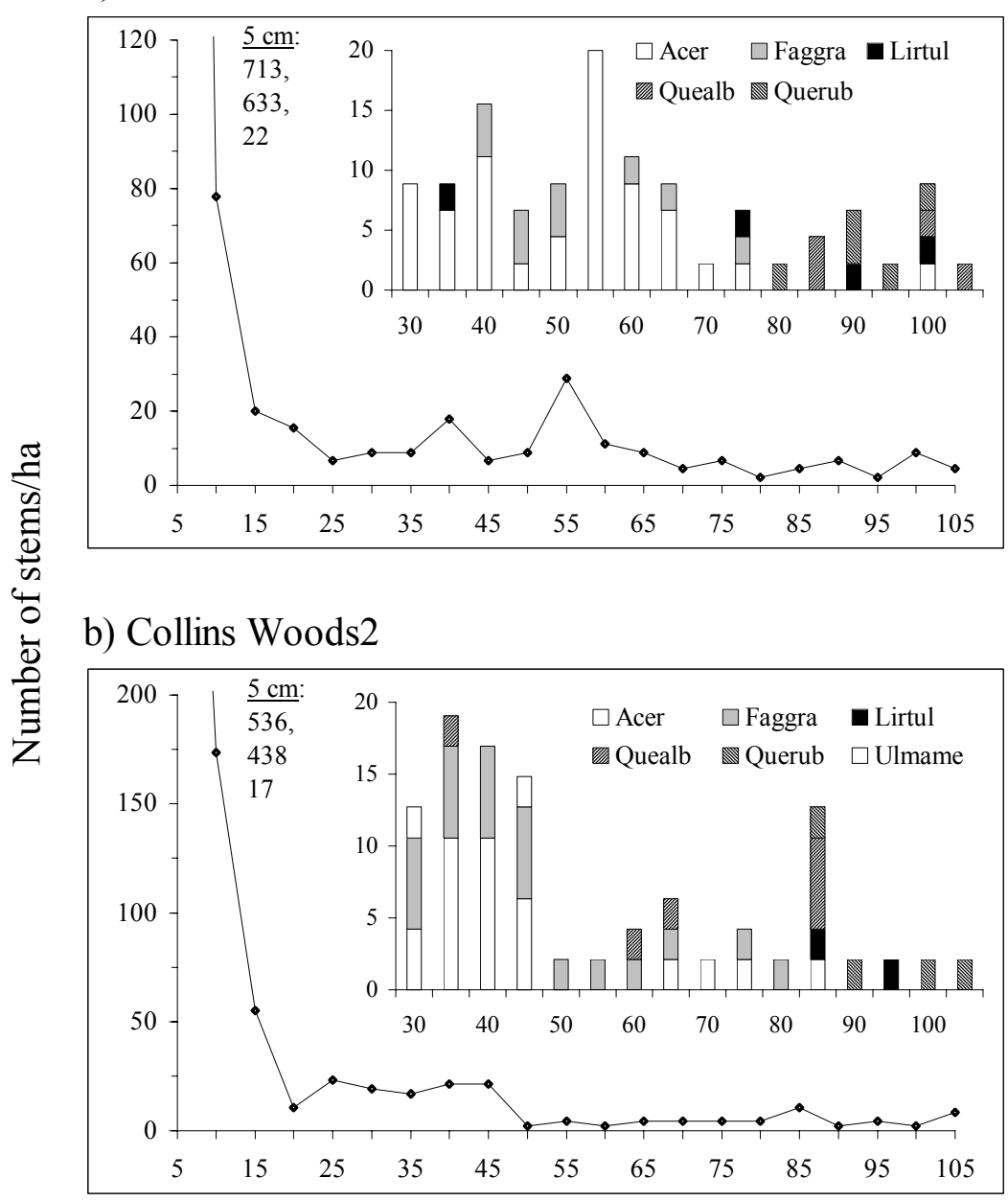

c) Wrights Woods 1

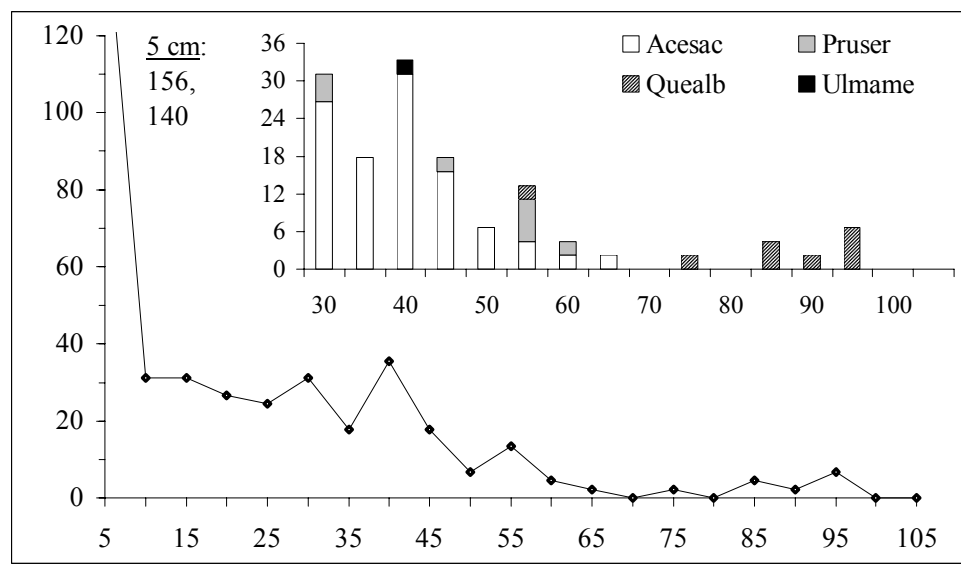

d) Wrights Woods2

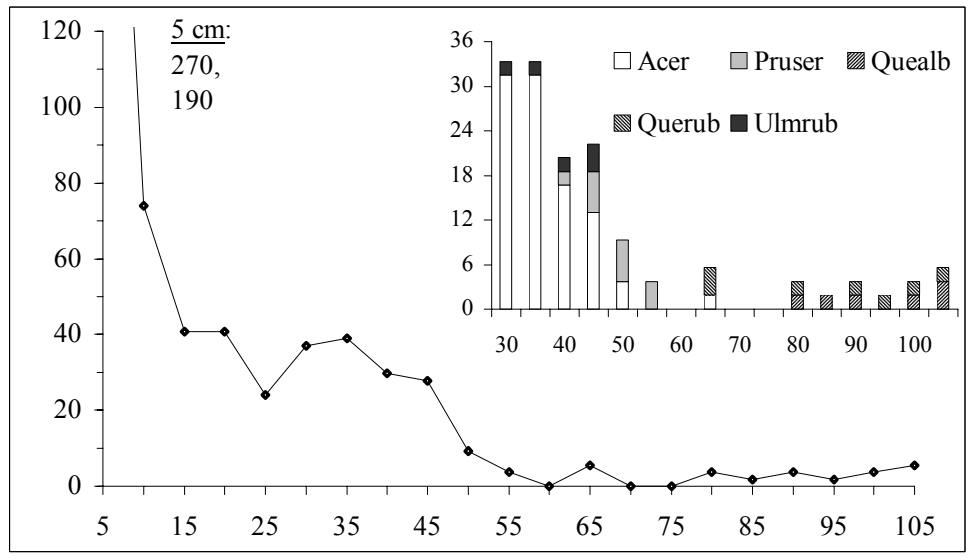

Midpoint of $10 \mathrm{~cm}$ DBH class (cm) 
Figure 4.4, continued.

e) Horners Woods 1

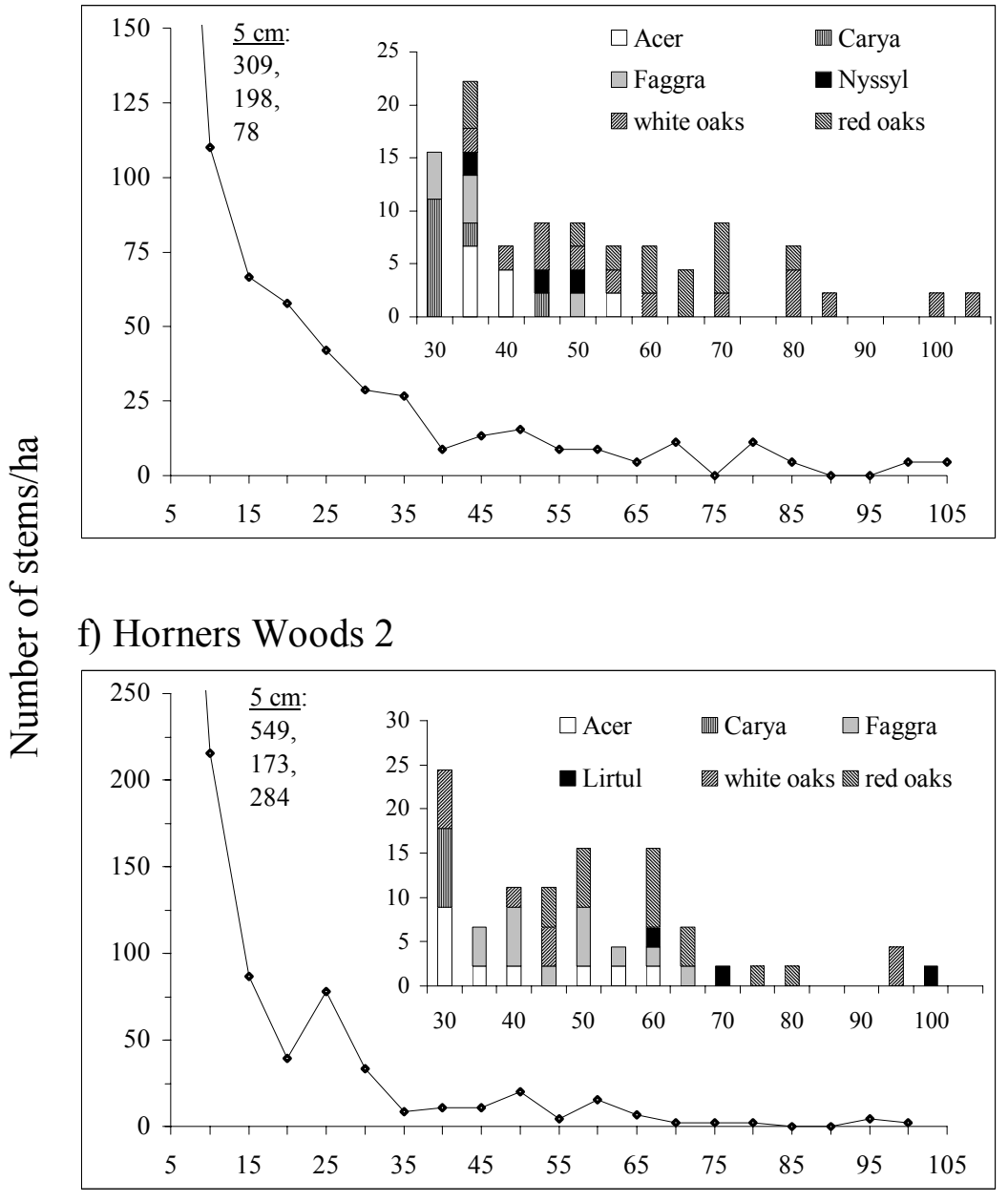

f) Murphy Tract 1

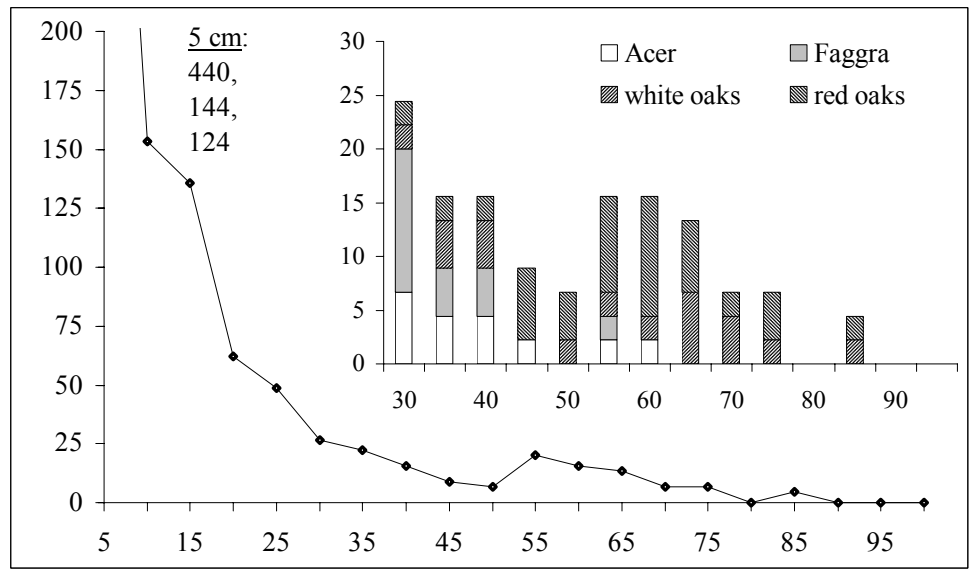

g) Murphy Tract 2

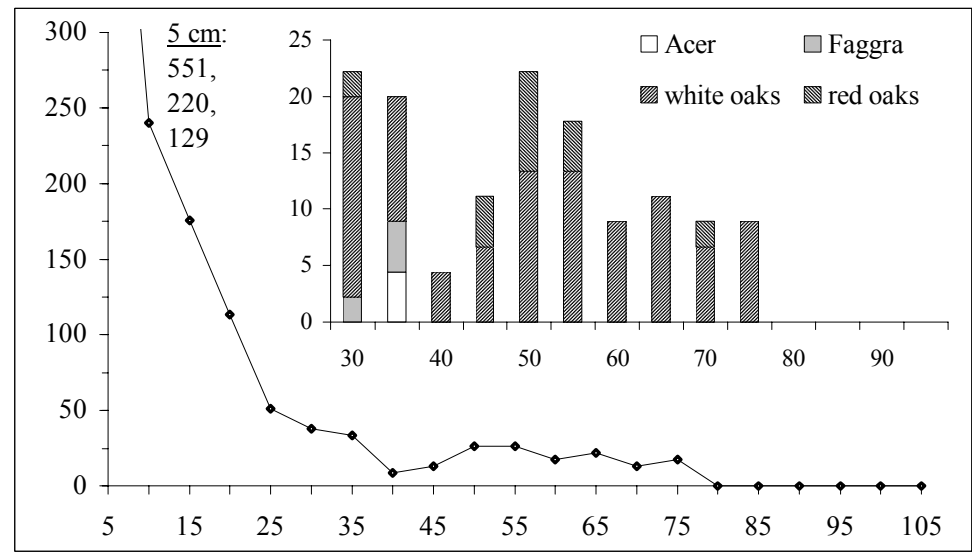

Midpoint of $10 \mathrm{~cm}$ DBH class $(\mathrm{cm})$ 
Figure 4.4, continued.

i) Watter Smith State Park

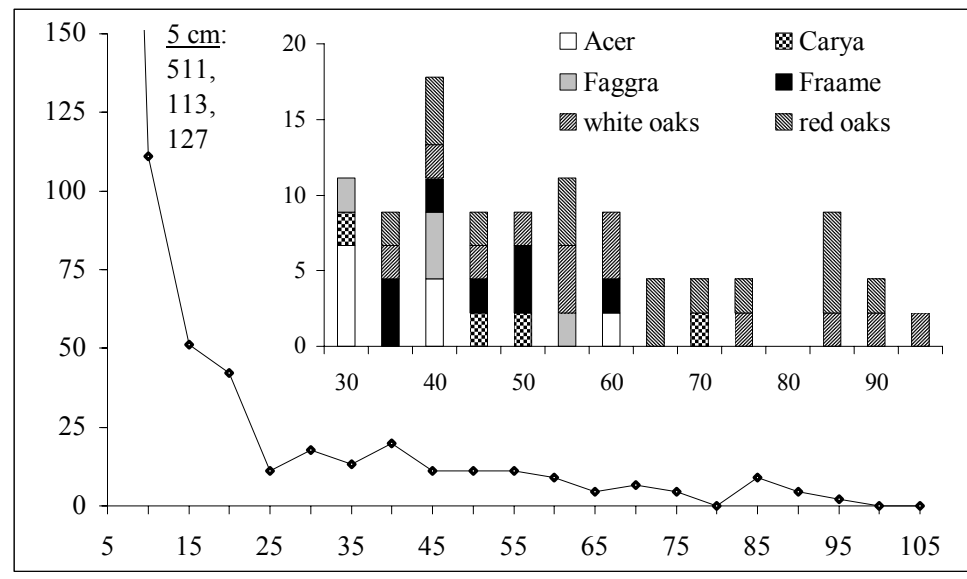

Midpoint of $10 \mathrm{~cm}$ DBH class (cm) 
Figure 4.5. Examples of diameter distribution trends for selected canopy tree species.
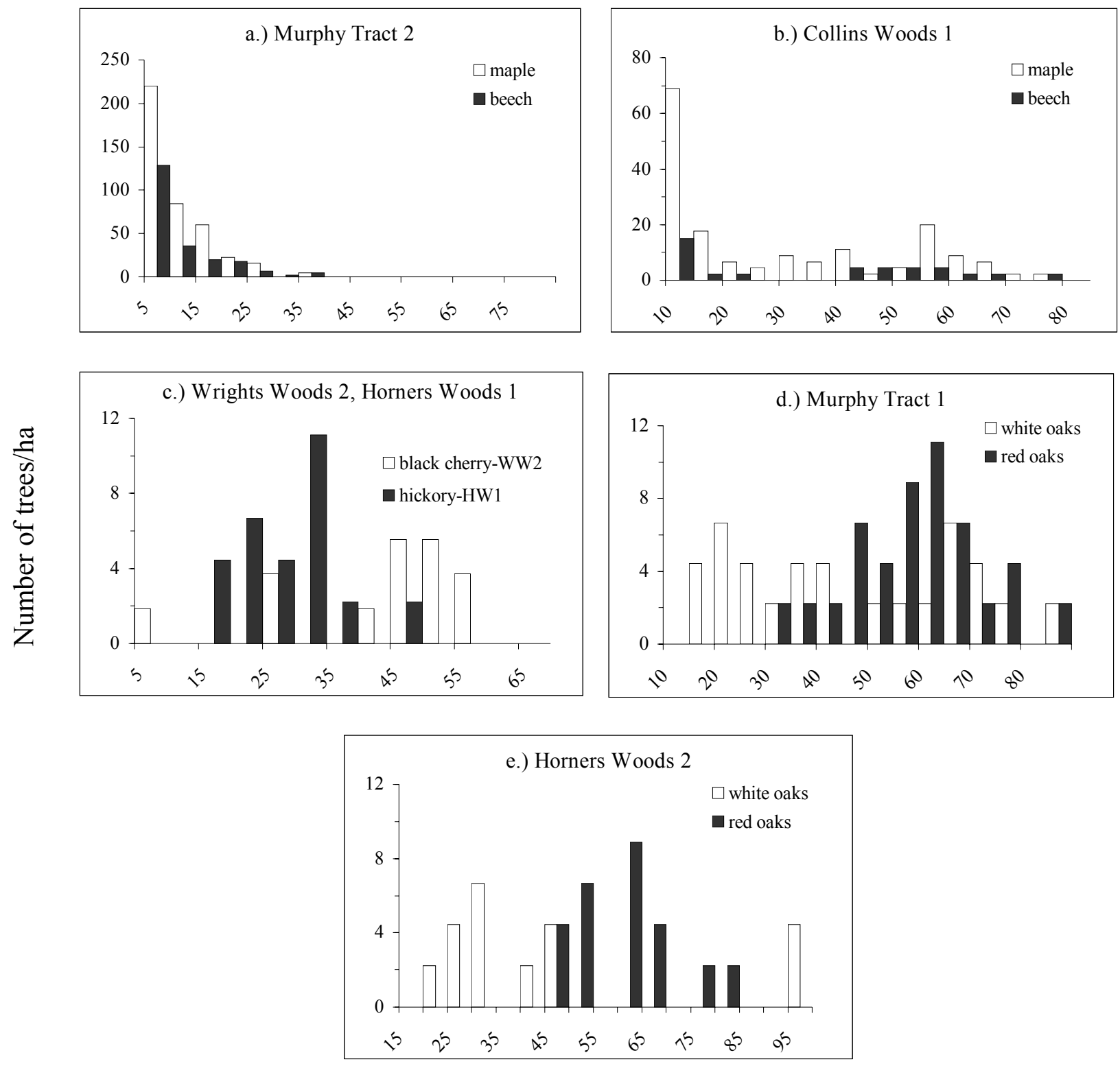

Diameter class $(\mathrm{cm})$ 
Figure 4.6. Density distribution of all stems $(\mathrm{dbh} \geq 2.5 \mathrm{~cm})$ for five old-growth forests in Ohio, Pennsylvania, and West Virginia. $\mathrm{Y}$-axis is $\log _{10}$ of density (trees ha ${ }^{-1}$ ), $\mathrm{X}$-axis is the center of the 5 -cm dbh class. Data points are fitted to a third-order polynomial.
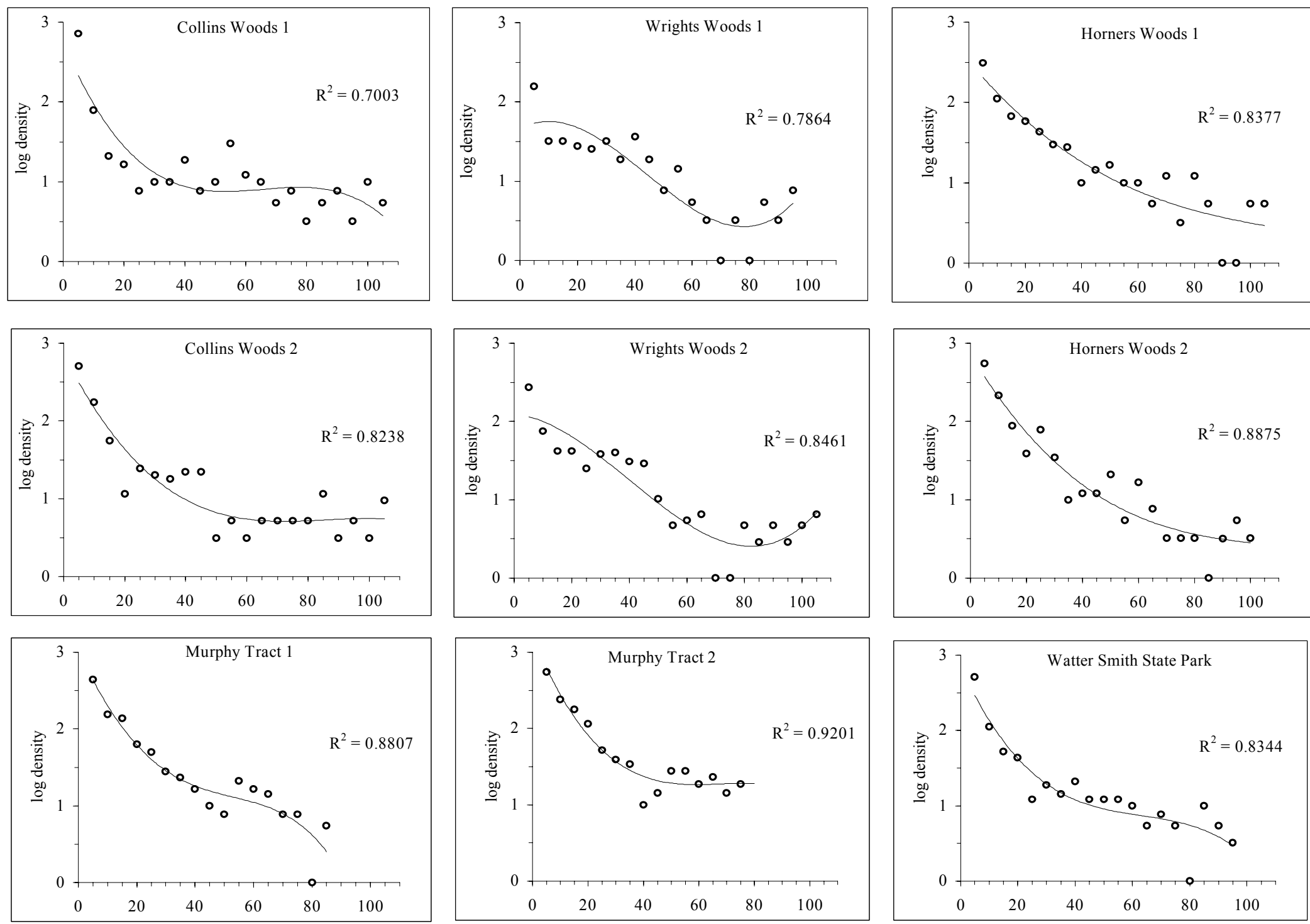

Midpoint of $5 \mathrm{~cm}$ dbh class 
Figure 4.7. Diameter $(\mathrm{cm})$ versus age (at $\mathrm{dbh}$ ) scattergrams for cored overstory trees at five sites. Trees are pooled from two 0.45 ha study plots at each site, except for Watter Smith State Park. Ages of four chestnut oaks at Horners Woods, and seven white oaks at Murphy Tract were estimated using linear regression equations $\left(R^{2}=0.589,0.754, p<0.0001\right)$.
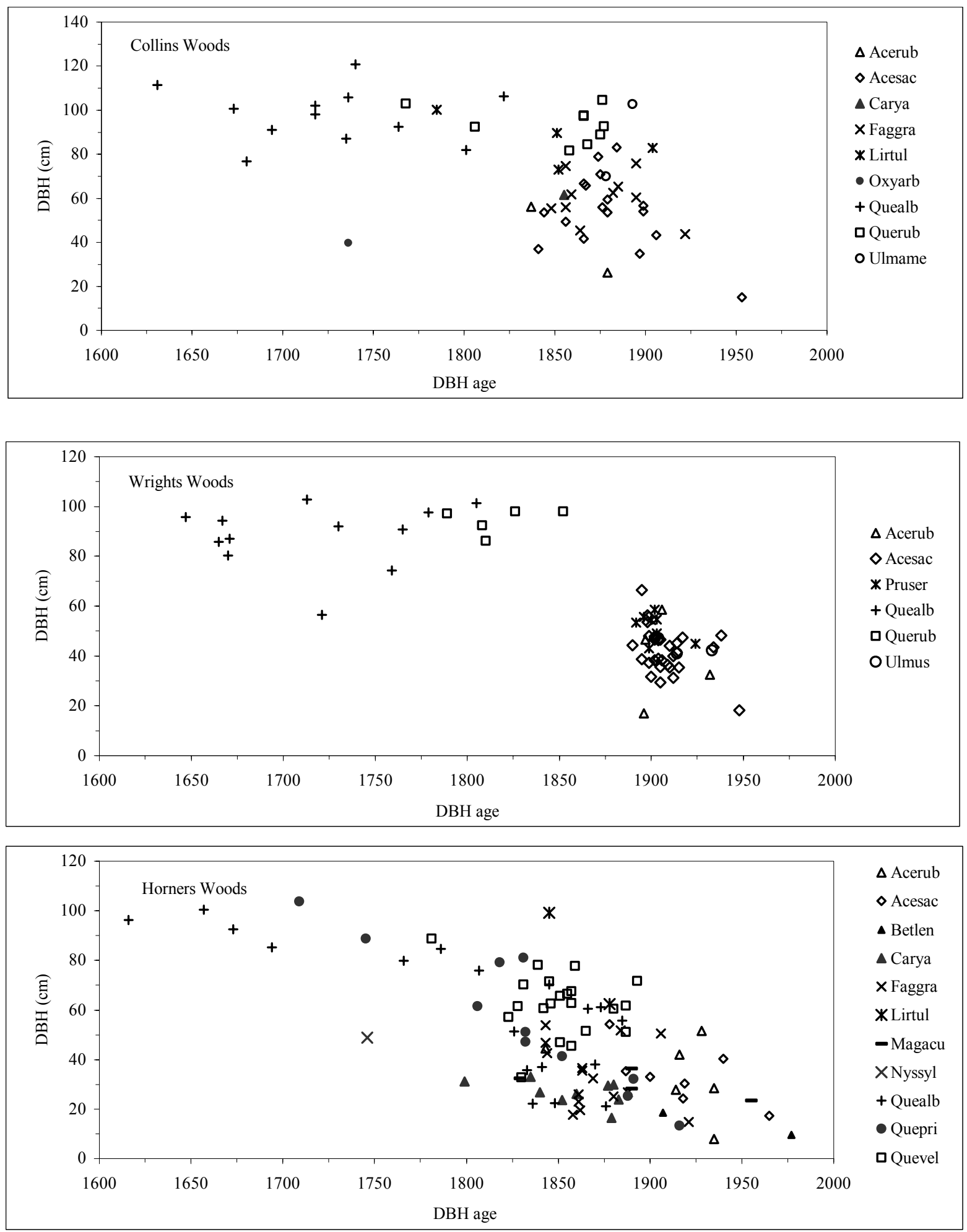
Figure 4.7, continued.
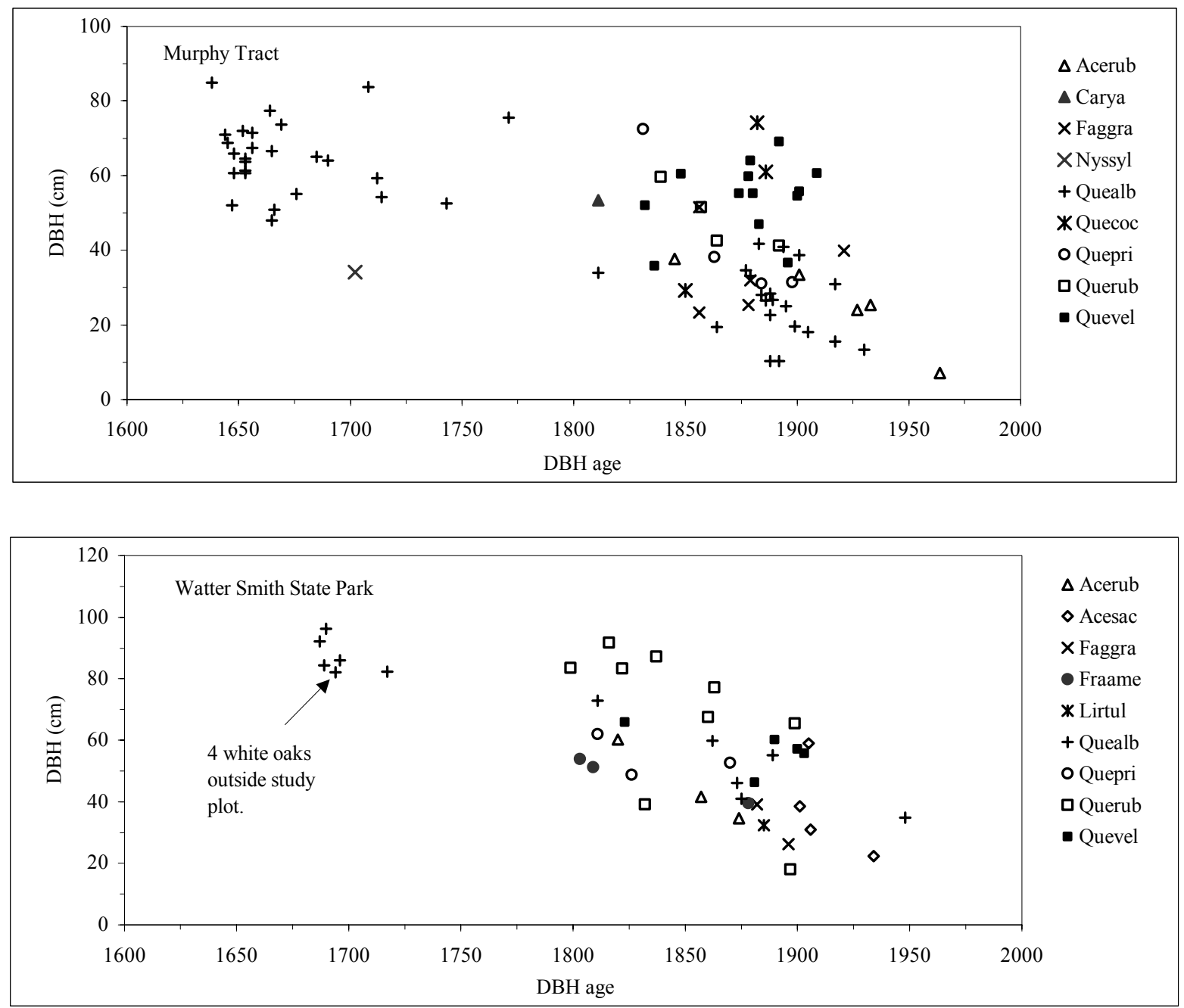
Figure 4.8. Examples of white oaks in the initial disturbance-related cohort that have early growth patterns that suggest establishment in large gap or open-growth conditions.
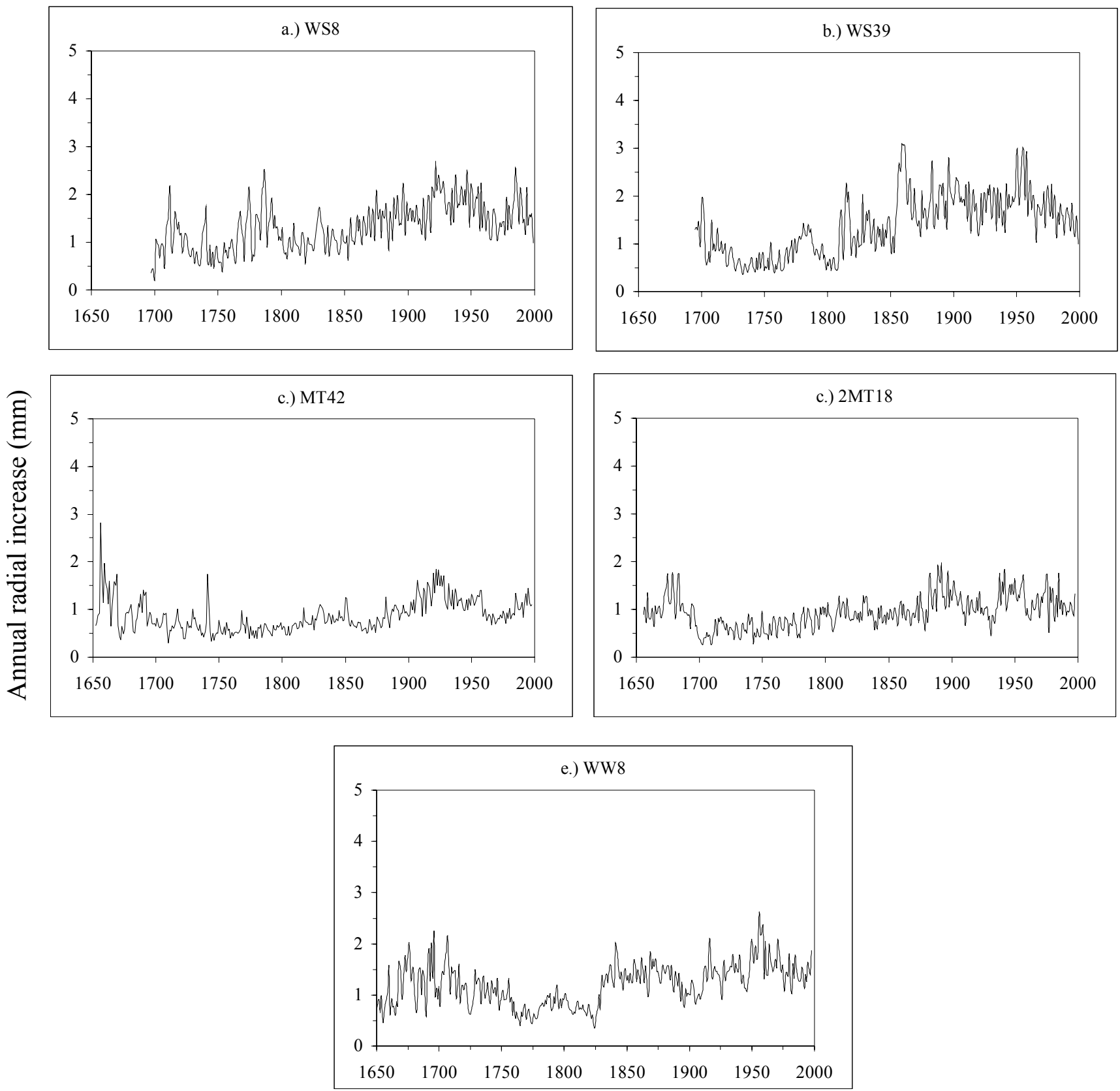
Figure 4.9. Diameter distribution of coarse woody debris ( $\geq 15 \mathrm{~cm}$ at base) by percent of total for $10 \mathrm{~cm}$ diameter classes. Data are averaged from two plots, except for WSSP.

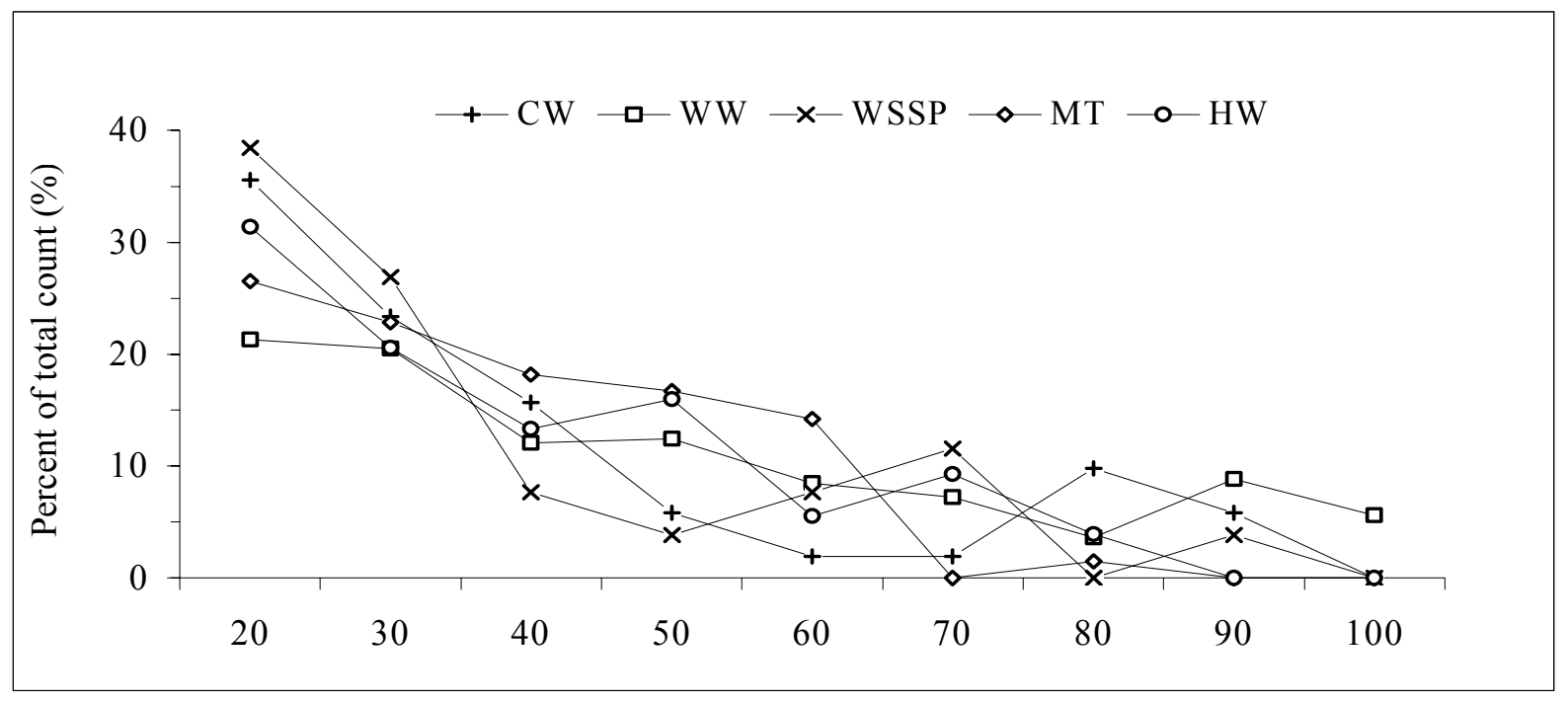


Figure 4.10. Morisita index of disperson $\left(\mathrm{I}_{\mathrm{d}}\right)$ for volume of downed logs, and frequency of standing snags at $15 \mathrm{~m}, 30 \mathrm{~m}, 45 \mathrm{~m}$, and $60 \mathrm{~m}$ spatial scales. See text for discussion of statistical significance.
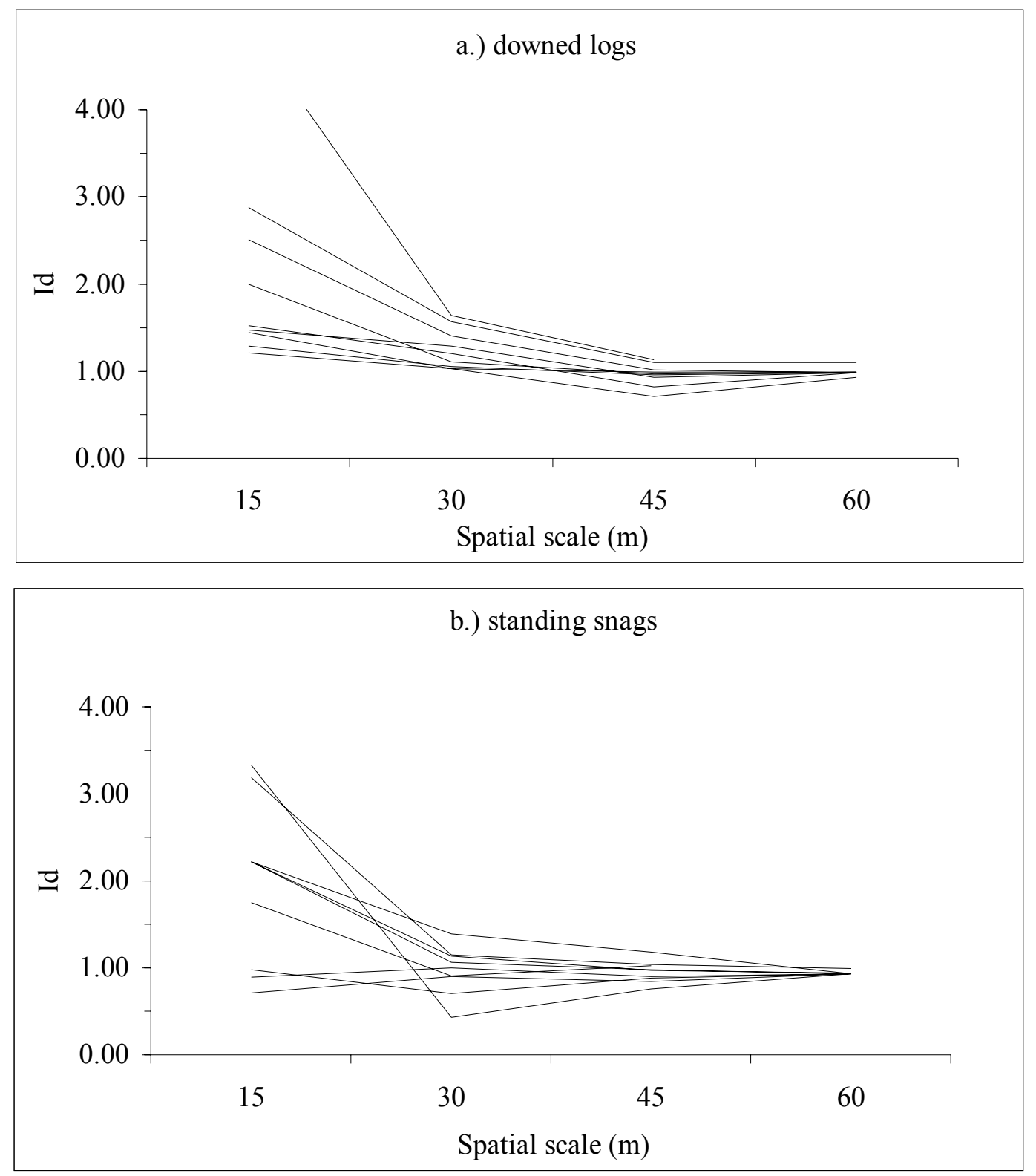
Figure 4.11. Density distribution of subplot aspect and direction of fall for snaps and tips for five oakdominated old-growth forests in Ohio, Pennsylvania, and West Virginia. Y-axis represents number of stems, and $\mathrm{X}$-axis represents upper boundary of each 45 degree interval (i.e., 45 includes all stems on slopes with aspects 0-45 degrees).
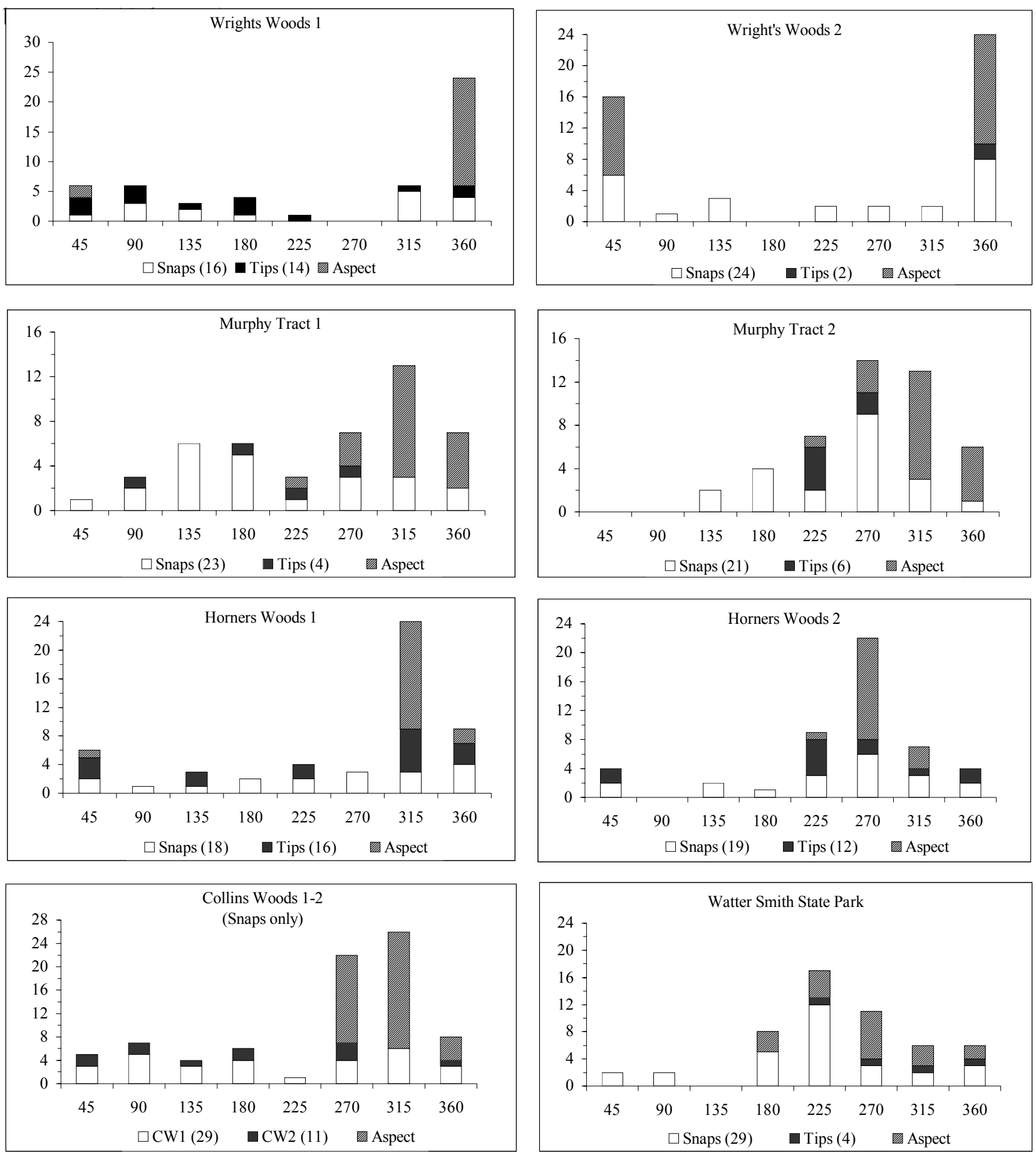
Figure 4.12. Diameter distribution of canopy gap makers (a), gap fillers (b), and border trees (c), by percent of total.
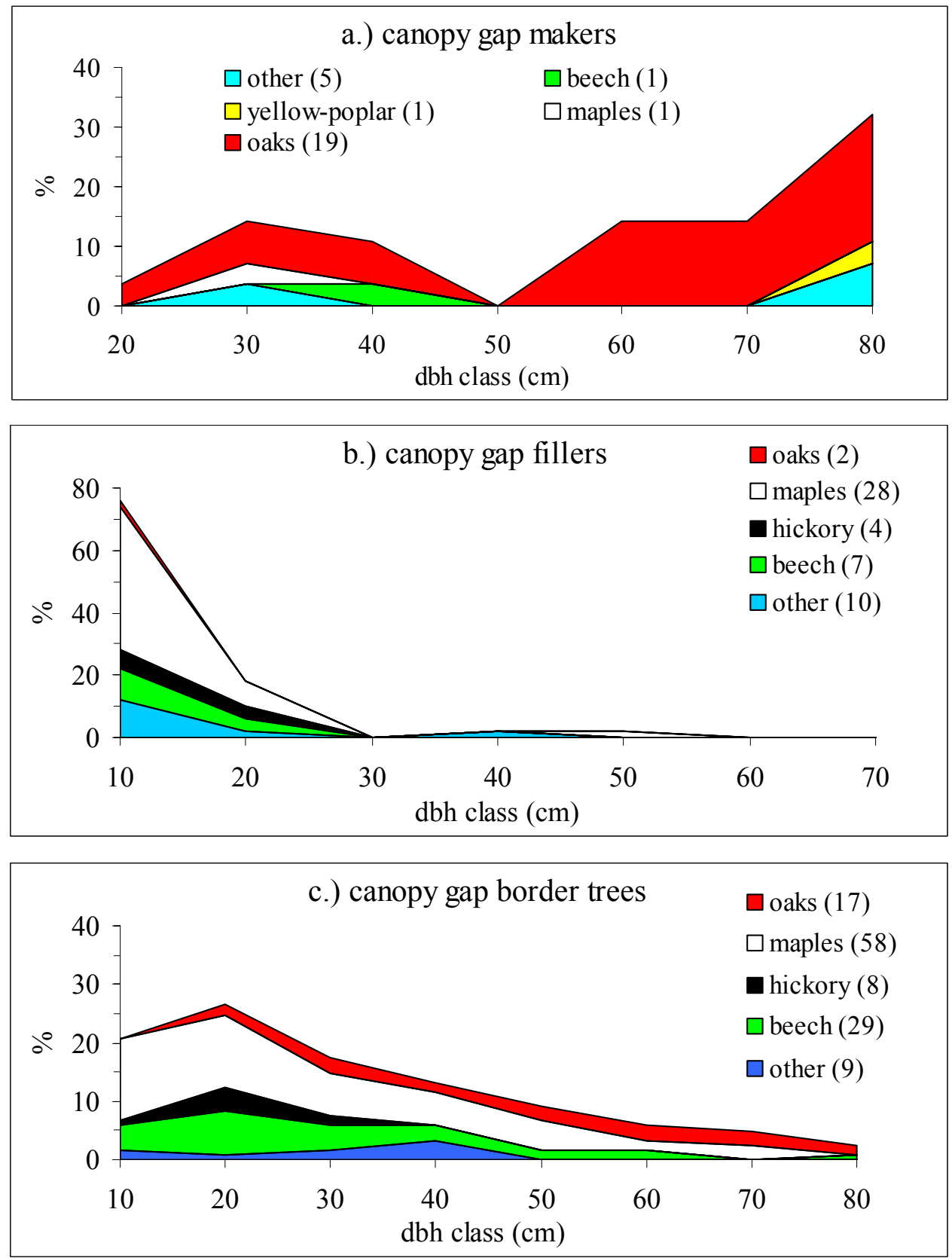

Other $=$ buckeye, black birch, cucumber, black gum, sourwood, horphornbeam, black cherry and unknown spp. 
Figure 4.13. Detrended correspondance analys is (DCA) of understory (_us), understory regeneration ( $\mathrm{reg}$ ) plots, and gap regeneration (_gap) plots, by species importance values.

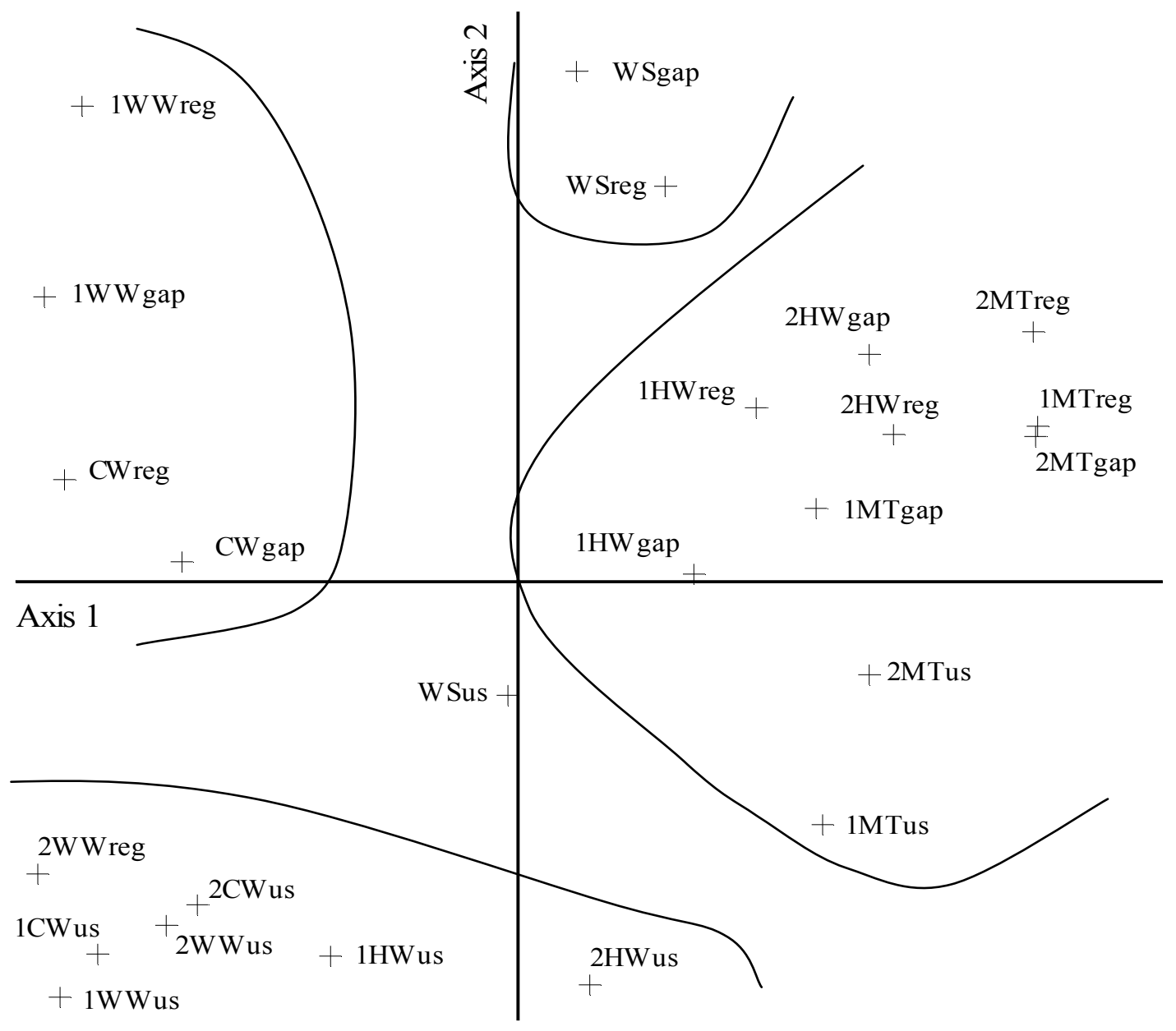




\title{
CHAPTER 5
}

\section{CANOPY DISTURBANCE INTERVALS, EARLY GROWTH}

\section{RATES, AND CANOPY ACCESSION TRENDS}

\begin{abstract}
Using a radial growth averaging technique, changes in growth rates of older, overstory oaks were used to quantify canopy disturbance events at five old-growth sites. On average, at least one canopy disturbance occurred on these study sites every three years; larger multiple-tree disturbances occurred every 17 years. Although there was some variation by site and by historical period, there has been little significant change in canopy disturbance rates for the 300year period reviewed. A review of tree-ring chronologies yielded three growth strategies. For these oaks, the likelihood of originating in a large opening and achieving overstory status before canopy closure is about the same as the probability of requiring a major release, either from the understory or from a smaller gap that closed. Half of the cored trees established as seedlings or spouts individually, and 30\% attained overstory status individually, members of no identifiable cohort. The majority of multiple-tree events occurred in gaps $<200 \mathrm{~m}^{2}$ in area. For trees that required a major canopy release, understory residence times averaged 89, 54, and 50 years for white oak, red oak, and black oak, respectively. Although there is some historical precedence for these values, few contemporary second-growth forests contain understory oaks of this age, particularly red oak. In view of the lack of change in canopy disturbance rates, these long understory residences averages suggest that the level of understory shade, and by implication, the abundance of shade tolerant understory species, was considerably less in the period before 1900 .
\end{abstract}


This hypothesis is consistent with presettlement survey tree-tallies, the absence of shade tolerant species in the oldest cohorts, and fact that virtually no oaks that recruited after 1900 did so after understory initiation. 


\section{Introduction}

Natural disturbances in forests kill vegetation and release growing space (Oliver and Larson 1996). They are simultaneously a source of mortality for some individuals and a source of establishment and growth for others, and the processes of death and replacement have a profound effect on forest structure and composition. In fact, many features of forests are better explained as responses to different kinds of disturbances rather than the result of a continuous change toward equilibrium (Brubaker 1987). The disturbance regime of a forest represents the sum total of stem and stand replacing events and many studies have characterized individual stands and forest types by disturbance agents, severity, and return time (Barden 1980; Romme and Martin 1982; Runkle 1982, 1985). In eastern, mesic, deciduous forests, tree-fall gaps are the dominant disturbance type (Crow 1988; Runkle 1982), especially as forests mature. These events create resource heterogeneity along light, temperature, humidity, and soil-resource gradients. The amount, timing, and quality of available light may vary as functions of gap size, the depth of shade imposed by the height of the surrounding canopy, solar angle, latitude, and aspect (Canham et al. 1990). Silvicultural treatments such as crown thinning, crop tree release, shelterwood and selection systems all recognize the importance of managing the light environment to favor growth of selected trees, and are designed to mimic the changes in light availability resulting from natural disturbances.

This chapter reviews disturbance regimes of five oak (Quercus L.) dominated old-growth forests in eastern Ohio, southwestern Pennsylvania, and central West Virginia (Figure 5.1). The primary focus is overstory dynamics, the rate and mode of canopy mortality and replacement. Two fundamental ecological principles guide this discussion. First, the growing space of a forest is defined as the sum of essential resources — sunlight, water, nutrients, heat, oxygen, and carbon 
dioxide — available to the individual organisms present (Oliver and Larsen 1996). Each tree in a forest utilizes a portion of the growing space and grows until one factor becomes limited or is no longer available. In the closed canopy, deciduous forests, light levels beneath intact canopies often become limiting, averaging as little as 1-2\% of full sunlight (Canham and Burbank 1994). Canopy disturbances that alter light availability are thus very influential in determining individual tree growth and survival, and often overshadow climatic factors (Phipps 1982; Nowacki and Abrams 1997).

The second guiding ecological principle is that, over time, there is a fundamental compatibility between the presence of a species and the prevailing disturbance regime. High disturbance rates that create large openings tend to select for exploitative species: fast-growing, light-demanding pioneer species that grow rapidly and mature early (Bormann and Likens 1979; Hicks 1998). Low disturbance rates favor conservative species: those that are longer-lived and that can tolerate shade and exploit temporary canopy openings (Grime 1977; Bormann and Likens 1979; Runkle 1985; Hicks 1998). Thus, the species that inhabit a forest have life history strategies — modes of establishment, growth, and reproduction — that are compatible with the size-distribution of disturbance patches (Denslow 1980, 1985). Changes in species composition then point to changes in the disturbance regime, and because the process of tree replacement begins on the forest floor, a discussion of understory dynamics forms an integral part of an overall consideration of the disturbance regime.

An understanding of the natural disturbance regimes of these five oak-dominated oldgrowth forests is essential. Following the glacial retreat, oaks began migrating north about 10,000 years ago, and reached their present range 7000 years ago, preceding American beech (Fagus grandifolia Ehrh.) and American chestnut [Castanea dentata (Marsh) Borkh.] by as 
much as 3000 years (Davis 1981). Presettlement surveys from the region during the late 1700s and early 1800 s attest to oak dominance (Chapter 2), and areas dominated by oak during this period tended to remain in oak whether they were logged by settlers or not (Lorimer et al. 1994). As early as the 1950s, forestry literature has included accounts that detailed problems with oaks regenerating on sites where they had been historically dominant. Problems were most pronounced on better sites, and the problem was regional in scope. Some of the earliest accounts considered second-growth, managed stands (Weitzman and Trimble 1957; Carvell and Tryon 1961), however, a similar trend has been noted in old-growth preserves (McGee 1984; Parker et al. 1985; Cho and Boerner 1991; also this study, Chapter 4). Foresters have demonstrated remarkable ingenuity in trying to resolve the oak regeneration problem. A variety of forms of stand manipulation targeting overstory light levels, understory light levels, and inter-species competition have been attempted, including clearcutting, patch or strip clearcutting, shelterwood treatment, prescribed fire, underplanting with tree-shelters, and herbicide treatment of understorys, for example. More recently, manipulative experiments have been supplemented by ecological studies that seek to understand, and then duplicate, the conditions that fostered oak stands in the first place (Schuler 1998). The old-growth forests of this study are especially suitable for study since they may hold the ecological answers to why oaks were historically successful, and why they are currently being replaced. They have an oak component that has survived for several hundred years. They are, to varying degrees, free of modern anthropogenic disturbances such as harvesting. At the same time due to their great age, they are a repository of evidence of other disturbances such as fire; chronologies of the older trees include periods of high fire exposure as well as the modern period of fire suppression. Although few in number and usually limited in size, they are the best living remnants of presettlement forests (Davis 1996). 
The tree-ring chronologies of the oldest cohorts provide a record of early environmental conditions, and the radial growth averaging technique evaluated in Chapter 3 provides a method of reconstructing the dynamics of canopy disturbance, tree growth, and canopy accession.

This study uses dendroecological techniques to supplement the presettlement witness tree survey data of Chapter 3, and community sampling techniques and stand-level dynamics of Chapter 4. This chapter has three objectives. First, what is the historic rate of canopy disturbance and tree release of the five old-growth stands? Intervals between years when at least one canopy disturbance occurred, and intervals between years when larger disturbances occurred were examined over the entire tree-ring chronology of each stand. Disturbance intervals were also compared for several historical periods. The second objective focuses on individual tree dynamics. Early oak growth rates and the presence or absence of a major crown release were used to determine modes of establishment and canopy recruitment, and by inference, the understory light environment in which trees originated. The third objective adds a spatial dimension to disturbance frequency by using plot maps and tree establishment and release chronologies to reconstruct the size-distribution of openings created by canopy disturbance events.

Study area and data collection methods

Study sites were selected using four criteria: 1) the presence of large $(\mathrm{dbh}>75 \mathrm{~cm})$, old (>200 yr) oak trees; 2) the presence of at least three cohorts; 3 ) a minimum level of identifiable human disturbance (e.g., logging, grazing); 4) a minimum size of $\sim 4$ ha, large enough to hold two 0.45 ha study plots, and to maintain a buffer of at least $50 \mathrm{~m}$ from plot borders to the edge of the stand; and 5) a relatively homogenous stand composition that is dominated by deciduous 
trees with a strong oak component. Stands, which generally satisfied these criteria, were found in eastern Ohio (Collins Woods, Belmont County), southwestern Pennsylvania (Wrights Woods, Washington County), and three in central West Virginia (Watter Smith State Park, Harrison County, Murphy Tract, Ritchie County, and Horners Woods, Lewis County). At Watter Smith State Park, only one 0.45 ha plot was established.

Each 0.45 ha study plot (60 m x $75 \mathrm{~m}$ ) was subdivided into $20-15 \mathrm{~m}$ x $15 \mathrm{~m}$ subplots, and a $100 \%$ inventories of overstory $(\mathrm{dbh} \geq 15 \mathrm{~cm})$ and understory $(2.5 \mathrm{~cm}>\mathrm{dbh}<15 \mathrm{~cm})$ stems were conducted. Importance values were calculated for each canopy stratum by averaging relative abundance $\left(\right.$ stems $\left.\mathrm{ha}^{-1}\right)$, relative basal area $\left(\mathrm{BA} \mathrm{ha}^{-1}\right)$, and relative frequency.

The largest tree in each subplot was cored at breast height. Two cores were extracted, generally on the side-slope side of the bole, to avoid tension wood. Additional trees were also cored, particularly if they were oaks. Cores were prepared using standard dendrochronological techniques (cf. Stokes and Smiley 1968). Cores were cross-dated by matching unique patterns of narrow and wide rings, and measured under a dissecting microscope to the nearest $0.001 \mathrm{~mm}$ in conjunction with $\mathrm{J} 2 \mathrm{X}^{\circledR}$ software. Tree-ring dating was validated using the program COFECHA (Grissino-Mayer et al. 1997), and the two cores for each tree were then averaged to yield a mean chronology for the tree.

\section{Data analysis}

Canopy disturbance. Canopy disturbances are identified empirically by an abrupt and sustained increase in tree-ring width, using the decadal averaging technique of Nowacki and Abrams (1997) that was described in Chapter 3:

$$
\% \mathrm{GC}=\left[\left(\mathrm{M}_{2}-\mathrm{M}_{1}\right) / \mathrm{M}_{1}\right] * 100 \%
$$


where $\% \mathrm{GC}=$ percentage growth change, $\mathrm{M}_{1}=$ preceding 10 -year mean radial growth (inclusive of the disturbance year), and $\mathrm{M}_{2}=$ subsequent 10-year mean (exclusive of the disturbance year) (Nowacki and Abrams 1997). Based on the WVU Forest results evaluated in Chapter 3, there is a linear relationship between $\% \mathrm{GC}$ and disturbance severity/crown release $(\mathrm{y}=k+0.92 * \mathrm{x}$, where $\mathrm{y}=\% \% \mathrm{GC}$ and $\mathrm{x}=\%$ crown release). To standardize methods, a 10 -year interval with a one year lag were used, even though there was some evidence that different intervals and lags worked slightly better for different species (see Chapter 3; also Dale 1968; Schlesinger 1978; Graney 1987; Cutter et al. 1991).

Three levels of crown release were recognized, using the criteria of Lorimer and Frelich (1989) and Schuler and Fajvan (1999): 1) major releases were defined as events where \%GC $\geq$ $100 ; 2$ ) moderate releases were classified as those with a \%GC 50-99\%; and 3) small releases resulted in \%GC of 25-49\%. Major releases correspond to overhead releases of smaller, overtopped saplings and pole-sized trees in canopy openings. Small releases apply to gapassociated growth increases caused by increased sidelight to trees already in the overstory, however overtopped trees may show an increase of this magnitude when neighbors die from selfthinning processes. Silviculturally, major releases are comparable to liberation cutting and thinning of dominants, while small releases are similar to one-sided crown thinning of codominants (Nyland 1966). Mean number of disturbances per tree, and duration of releaseresponse (years when $\% \mathrm{GC}$ was continuously $\geq 25 \%$ ) were compared by species, site, and tree age, using ANOVA (PROC-GLM, SAS Inst. 1998).

The maximum value for $\% \mathrm{GC}$ of major releases was quite large $(331 \%)$. Within this class, Nowacki and Abrams (1997) further differentiated between disturbances that elicited a $\%$ GC $100-150 \%$, which they equated to a single crown-class advancement, $150-199 \%$, 
comparable to two crown-class advancements, and $\geq 200 \%$, comparable to three crown-class advancements. These classes were not applied in this study. From the analysis of chestnut oak and northern red oak response in the thinning experiment at the WVU Forest (Chapter 3), the relationship between $\% \mathrm{GC}$ and percent crown release was best approximated by a straight line. According to this model, a four-sided release yielded, on average, a growth change of approximately $90-100 \%$. Here, when $\% \mathrm{GC}$ values exceeded $100 \%$ by a large margin, the increases were attributed to extremely low pre-disturbance growth rates and overstory suppression (Minckler 1967), rather than reflecting a biologically realistic level of crown release.

Canopy disturbance intervals. Two types of canopy disturbance intervals were investigated: 1) single-tree event intervals, or the time period between those years when at least one canopy disturbance-crown release occurred in the study site, and 2) multiple-tree event intervals - the time period between years when two or more non-adjacent trees underwent a release. Years in which at least one disturbance occurred were readily identified. For multipletree disturbances, a histograph of all events at each site was compiled, and years were identified by the peaks of the curve.

There are three potential sources of ambiguity in this methodology. First, sample size varied with time; i.e., more sample trees were alive in 1900 than in 1700 . Thus, strict quantitative criteria for identifying multiple-tree disturbances could not be applied. For example, when only four sample trees were available for analysis of 1700 -era disturbances, a $50 \%$ cutoff was reasonable. However when sample size increased to 40 trees in 1900, for example, the involvement of $50 \%$ of the sample trees could indicate a much larger disturbance, and the criteria would overlook less extensive disturbances (i.e., ten trees out of 40) that should still qualify as multiple-tree events. In order to make sample sizes comparable, only trees $>150$ years old were 
used in this analysis. Multiple-tree events were then identified graphically by peaks in the histograph of all site disturbances

Second, the \%GC technique, as defined, assumes that there is a one-year lag between the disturbance event and release-response. However, the response-time may vary according to the precise timing of the disturbance event. For example, a disturbance in January (heavy snow, glaze, for example) may precede the growing season enough for a growth increase to occur in the same calendar year, while one in July (windthrow), after most of the radial growth is completed, would not be apparent until the following year. In addition, a precise correlation does not always exist between peak \%GC as calculated, and the actual disturbance year (Schuler and Fajvan 1999). In the experiment at the WVU Forest, for example, peak values of \%GC for several release-classes of northern red oak indicated a 1983 disturbance year, one year after the actual thinning. Differences in individual tree genetics and physiological condition before the disturbance as well as species-level differences may also affect the precise time of response (Lorimer and Frelich 1989; Schuler and Fajvan 1999). To account for the variability in timing of disturbance and peak \%GC, disturbance events were initially assigned a three-year window (peak \%GC-year \pm 1 year), and these data were the input for each site's disturbance histograph. While using a three-year window for disturbance year potentially inflates the disturbance frequency by a factor of three, a single year was assigned to each disturbance based on the peaks of the curve.

Disturbance interval is a statistical measure of central tendency that indicates how often disturbances tend to occur at a site. Because these data have a minimum bound of one year and, theoretically, an upper bound defined by trees' maximum longevity, disturbance return intervals are often positively skewed and not well described by the normal distribution (Grissino-Mayer 
1997). Reviewing fire history data, Baker (1992), Grissino-Mayer (1997) and Sutherland (1997) found that a Weibull distribution provided a better fit of the data, and its median was a more robust estimate of central tendency. The Weibull median is expressed as the 0.5 exceedance probability, corresponding to the $50^{\text {th }}$ percentile of the distribution, and the 0.125 and 0.875 exceedance probabilities provide a confidence interval, or thresholds of that median.

The FHX $2^{\circledR}$ program was originally designed to estimate fire frequency and to evaluate the goodness of fit between fire interval data and normal and Weibull distributions (GrissinoMayer 1997). First, the original data are transformed to reduce kurtosis and skewness so the data approximates normality, with a mean of zero and a standard deviation of one. Means of different periods can then compared using a t-test for both equal and unequal variances. Schuler and Fajvan (1999) used this software to model standwide canopy disturbance frequencies in secondgrowth stands with older residuals in West Virginia. Here, I use it to determine the frequency of single-tree and multiple-tree disturbances in older, oak-dominated stands that have experienced a minimum level of modern human influence. Weibull median disturbance intervals were first calculated for the entire tree-ring chronology for each site, and then means of different historical time periods were compared to detect within-site changes over time.

Disturbance intervals for three time periods were compared, based on a general assessment of human impacts and a variable fire regime (Nowacki and Abrams (1997). The presettlement period is defined as years before 1800 , during which a suite of natural disturbances such as glaze and windstorms, drought, and insect infestations and disease, as well as natural and Native American fire constituted the disturbance regime. The settlement period (1800-1899) corresponds to the period during which extensive land clearing for agriculture, forest harvesting, and associated slash fire occurred. The modern era (after 1900) is distinguished primarily by a 
fire suppression policy, the introduction of exotic pests and disease (e.g., chestnut blight and gypsy moth), and a dramatic increase in the white-tailed deer population. The bounds of each period are slightly different for each of the five study sites. For example, Wrights Woods was first settled around 1765, while the areas including Murphy Tract and Horners Woods were not settled until around 1800 (cf., Chapter 4). Similar differences apply to the onset of land clearing and farming, logging, and probably, fire suppression as well, although it is not always feasible to accurately pinpoint any particular trend in time. To equalize sample sizes and time considered as much as possible, I used the following time periods: 1700-1800, presettlement; 1801-1900, settlement; and 1900-1990, modern.

In addition to the five study sites of this study, tree-ring chronologies from three additional old-growth stands with a significant oak component were subjected to the same disturbance frequency analysis (Figure 5.1). The three stands were 1) Dysart Woods, Belmont County, Ohio (Rubino and McCarthy 2001); 2) Lilley Cornett Woods, Letcher County, Kentucky (Cook 2001); and 3) Joyce Kilmer Wilderness Area, Graham County, North Carolina (Cook 2001). Although all three stands have been extensively studied (e.g., McCarthy et al. 2001; Martin 1975; Lorimer 1980, respectively), specific information on dendrochronological sampling techniques (e.g., plot or transect based) and overall stand composition and structure at the time of sampling was not available. Nevertheless, they provide an additional test of the methodology, and a valuable basis of regional comparison of canopy disturbance regimes.

Early growth rates and canopy accession trends. Chapter 4 included a discussion of the age structure and stand dynamics of the five study sites. This section examines individual tree dynamics, focusing on early growth rates, and by inference, the light-environments in which trees originated. Average oak growth rates were computed for each site. Three distinct growth 
trends were identified based on juvenile growth rates (at dbh), overall growth pattern, and the presence/absence of a major crown release $(\% \mathrm{GC} \geq 100 \%)$.

a) Gap origin. The absence of a major crown release distinguishes this trend. Trees with average juvenile growth followed by a slightly increasing trend, (Fig. 5.2a), or trees with above-average initial growth and a flat or slightly declining trend (Fig. $5.2 \mathrm{~b}$ ) were considered to be direct overstory recruits in high-light conditions (Lorimer et al. 1988; Lorimer and Frelich 1989; Frelich and Graumlich 1994; Nowacki and Abrams 1997).

b) Gap origin-gap release. Radial growth during the first 25 years for these trees was similar to a), above. However, growth was subsequently reduced by canopy closure from above, and then resumed pre-suppression rates after a major release and overstory accession (Fig. 5.2c-d).

c) Understory origin-gap release. Initial growth for these trees was at least $50 \%$ less than the site average $\left(0.5-0.8 \mathrm{~mm} \mathrm{yr}^{-1}\right)$, and these trees were considered to have originated in a low-light, understory position. Following one, or occasionally, two major releases, growth showed a large increase and no further evidence of overstory suppression (Fig 5.2e-f).

For trees categorized as gap origin-gap release (b) and understory origin-gap release (c), dbh (inside bark, dib) at the time of final major release, understory residence time (age at overstory accession minus year of earliest ring) were evaluated by species and by site. Mean values of diameter (dib) and age at final major release (MRT, mean understory residence time) were calculated for each of the four oak species. 
Spatial distribution of tree establishment and release events. For each study plot, maps were prepared show cored-tree locations and establishment and canopy accession dates. Cohorts were identified by similar establishment and/or release years, and the patch-size was estimated by the distance between trees of the same cohort. Oak cohorts were evaluated spatially, based on two general questions. First, were trees established and/or released individually, or did these events occur in groups? This analysis corresponds to the singletree/multiple-tree disturbance chronologies outline above. Secondly, when multiple-tree events were identified, what was the relative patch size?

This analysis provides an estimate of synchrony of disturbance/release events and patch size. The method potentially under- or over-estimates them for several reasons. First, I assumed that if two (or more) trees showed the same establishment or release year, they owe it to the same disturbance and constitute a cohort. This may not be the case, since more than one disturbance may occur in a plot or adjacent points within a plot in the same year (Fajvan and Seymour 1993). This case would result in an over-estimation of patch size. By the same token, the absence of a live tree with the same establishment/release year as another one may be simply the result of the previous death of one of the trees. In this case, the cohort would have initially been larger, and thus patch size would be under-estimated. Some sites initiated after large disturbances, and thus patch-size exceeded the area of a single $60 \times 75 \mathrm{~m}$ plot. These cases were not included in this analysis, and thus true patch size may again be underestimated. Finally, because the margin of error of the radial growth averaging technique is \pm 1 year, some trees may be grouped in the same patch when in fact they were separated in time by one year. 
Results

Stand composition and structure. Oaks occupied, at minimum, a codominant position at all five study sites. At Collins Woods and Wrights Woods, the oak component was limited to a few very large, dominant trees, and the IV's of sugar maple (Acer saccharum Marsh., Wrights Woods) or sugar maple, beech, and red maple (Acer rubrum L., Collins Woods) equaled or exceeded those for oaks (Table. 4.4). At Watter Smith, Horners Woods, and Murphy Tract, the oak component was more dominant, numerous, and distributed among more species, size- and age-classes. In contrast, understory oaks ( saplings and pole-size trees, $2.5 \mathrm{~cm}>\mathrm{dbh}<15 \mathrm{~cm}$ ) were virtually absent from the understory strata at all five sites. Only at Murphy Tract, did the combined oak IV approach a value of 10 (Table. 4.5). Sugar maple and red maple were consistently the most abundant species in the regeneration plots, averaging 18,000 stems $^{-1}$. Oak advance regeneration was present at all plots but Collins Woods, but large oak seedlings (> $1 \mathrm{~m}$ tall) were found only at Murphy Tract, and even there, abundance was less than 200 stems $\mathrm{ha}^{-1}$ (see Table. 4.6)

Two trends characterized the age structure and oak recruitment at these sites (see Figure 4.7). At Collins Woods and Wrights Woods, establishment of oaks was limited to the period 1650-1875. White oaks (Quercus alba L.) were the oldest trees, however the most recent recruitment of this species occurred in 1850; red oaks (Q. rubra L.) first recruited between 17501800 and continued until 1850 at Wrights Woods, and 1875 at Collins Woods. Both sites showed large ingrowth of shade tolerant tree species in the 1800 s, as well as pioneer species such as yellow-poplar (Liriodendron tulipifera L.), pignut hickory (Carya glabra Mill.), American elm (Ulmus americana L), slippery elm (U. rubra Muhl.), and black cherry (Prunus serotina 
Ehrh.). At Watter Smith, Murphy Tract, and Horners Woods, white oak and chestnut oak ( $Q$. prinus $\mathrm{L}$.) were the oldest trees, and red oak and black oak ( $Q$. velutina Lam.) were recruited beginning in the early 1800s. These sites also showed gradual ingrowth of both shade tolerant and pioneer species in the 1800s, however, in contrast to Collins Woods and Wrights Woods, recruitment of oak species continued during this period.

The oldest trees at Wrights Woods, Watter Smith, and Murphy Tract date to well-defined time periods that suggest these stands initiated in the aftermath of a stand-initiating disturbance. The absence of clearly defined cohorts among the oldest trees at Collins Woods and Horners preclude a reliable estimate of stand origin. Here, the small number of old trees and wider age ranges make it difficult to determine if they are survivors of a large disturbance initiated and even-aged cohort, or remnants of a small cohort in a stand that has been uneven-aged for centuries. At all sites, shade tolerant species such as sugar maple and American beech were absent from the oldest cohorts.

Canopy disturbances. A total of 756 canopy disturbance events were identified from 173 overstory oak trees at the five study sites using the \%GC technique. Sixty percent (459) produced small releases $(\% \mathrm{GC}=25-49 \%), 26 \%(199)$ produced moderate releases size $(50$ $99 \%$ ), and $14 \%$ (101) were major releases involving overstory accession ( $\% \mathrm{GC} \geq 100 \%)$. The average number of disturbances per tree was 4.1. Older trees tended to show more releases because of longer exposure time in the overstory $(\mathrm{F}=103.9, \mathrm{p}<0.001)$; for example, one white oak underwent 13 separate small releases over 347 years. However, differences in the mean number of disturbances per tree were not statistically significant when either site or species were considered $(\mathrm{F}=1.09,0.22$, respectively, $\mathrm{p}>0.05)$. 
Duration of release was defined by the number of years between peak \%GC and when subsequent values fell below $25 \%$. Although strict criteria for the duration of release were not applied when identifying disturbances, there was good mean separation for the three release classes $(\mathrm{F}=368.8, \mathrm{p}<0.0001)$. Small releases lasted an average of 3.1 years; means for moderate-level and major releases were 8.2 and 10.8 years, respectively. Thus larger openings not only allow for greater growth, they also take longer to close.

Canopy disturbance intervals. Multiple-tree disturbance intervals were normally distributed, $(\mathrm{K}-\mathrm{S}$ test, $\mathrm{d}$-statistic $\leq 0.12, \mathrm{p}=0.15)$ but the distribution of single-tree intervals was highly skewed (skewness $>1$ ), and the normal distribution did not provide an adequate model (K-S test d-statistic $>0.184, \mathrm{p}<0.01)$. Because the Weibull distribution is flexible enough to approximate the normal distribution (Grissino-Mayer 1997), this model provided a better overall statistical fit and the Weibull median was used as a measure of central tendency.

Table 5.1a-b summarizes median disturbance intervals for single- and multiple-tree events for each site. Disturbance intervals were remarkably similar across the eight sites examined, despite variable sample sizes, and in the case of the three sites represented only by tree-ring data, unknown sampling techniques. Single-tree disturbances occurred about every three years, while larger, multiple-tree disturbances occurred every 17 years. The estimated upper threshold for single-tree intervals and the lower threshold values for multiple-tree intervals were generally consistent. The probability that single-tree events were more than 7.9 years apart was 0.125 ; conversely, the lower threshold for multiple-tree events was 8.6 years $(p=0.875)$. In other words, it is unlikely that canopy disturbances involving at least one tree are more than 7.9 years apart, and that the interval for larger events is less than 8.6 years. 
As is the case with fires (Frost 1998), disturbance frequencies have little value unless the sample unit is scaled. When estimating the occurrence of single-tree events, the sampling unit is "trees" that were at least 150 years old; accordingly, there was a strong negative relationship between the disturbance interval and number of trees sampled $\left(F=16.5, p=0.06, R_{\text {adj }}^{2}=0.84\right)$. For these plots, more intensive sampling could theoretically yield a smaller interval, limited only by the number of trees available for coring that meet the minimum age requirement. However, for multiple tree disturbances, estimated return interval and number of sample trees were largely independent of each other $\left(\mathrm{F}=3.7, \mathrm{p}=0.19, \mathrm{R}^{2}{ }_{\mathrm{adj}}=0.40\right)$. Here, the disturbance interval is better considered a site variable, representative of a particular stand, with certain compositional, topographic, and disturbance characteristics. Site, rather than tree or plot, is the more ecologically meaningful dimension of scale.

The historical comparison of disturbance intervals revealed a few differences by site. However even when statistically significant, most differences were small, within the \pm 1 year margin of error of the radial growth averaging method, and not ecologically meaningful. Similarity over time was the most significant finding. In addition, for each site, the direction of change between historical periods was generally consistent for single- and multiple-tree intervals (i.e., if single-tree intervals increased from one period to the next, so did multiple-tree intervals). There was a slight decline in single-tree disturbance intervals between the presettlement (1700$1800)$ and settlement (1801-1900) periods, and a slight increase during the modern period (19011990, Table 5.2a). Because the single-tree disturbance frequency is strongly correlated with number of sample trees, increasing sample depth accounts for a portion of these changes. On average, the interval between multiple-tree events slightly increased from an all-site average of 16 years in the presettlement era, to 19 years in the modern period (Table 5.2b). Increases were 
largest for Murphy Tract (+ 10 years), Watter Smith State Park (+ 6 years), and Joyce Kilmer Memorial Forest in North Carolina (+ 5). However the magnitudes of most changes were relatively small, and none were statistically significant.

Early growth rates and canopy accession trends. Using early growth patterns and the presence/absence of a major crown release $(\% \mathrm{GC} \geq 100 \%)$, tree origin and mode of canopy accession were classified in one of three ways: a) gap origin-no release, b) gap origin-gap release, c) understory origin-gap release (Figure 5.2, Table 5.3). For all trees, the likelihood of originating in a large opening and achieving overstory status before canopy closure $(\mathrm{N}=85)$, is about the same as the probability of requiring a major release, either from the understory $(\mathrm{N}=$ 66) or from a smaller gap that closed $(\mathrm{N}=22)$. White oak and red oak best exemplified this trend, with almost the same number of trees requiring at least one release from above $(\mathrm{N}=47$ and 16 , respectively) as those that did not show a large release (46 and 13, respectively). Chestnut oak was more likely to have originated in the shaded understory before release, consistent with its reputation as the slowest grower of these four species (Rogers 1990). In contrast, a higher proportion of black oaks were successful in using gaps to attain overstory status without being overtopped and then released.

Understory residence time (MRT) and dib at overstory accession for trees than survived being overtopped are shown in Table 5.4. White oak averaged 89 years before reaching the overstory at an average dib of $15.3 \mathrm{~cm}$. Red oak and black oak attained overstory status sooner (51 and 50 years, respectively) and at smaller diameters $(11.8$ and $11.0 \mathrm{~cm}$, respectively, see Figure 5.3 for examples). Variability of residence time was very high. For example, at Wrights Woods and Murphy Tract, the range of understory residence time for white oak was 20-215 years. 
Only 13 of the 176 oaks examined showed more than one major crown release. This contrasts to sugar maple and beech that may require 2-5 repeat gap events before overstory accession (Canham 1985; Runkle and Yetter 1987). While setting a 100\% GC as evidence of overstory recruitment was somewhat conservative, the fact than so few oaks showed more than one release of this magnitude is consistent with this definition. The effect of growing in prolonged overstory shade is born out by a comparison of understory residence time and dib at the initial and final release times. For white oaks that showed more than one major release $(\mathrm{N}=$ 9), total MRT and dib were 111 years and $17.8 \mathrm{~cm}$.

Spatial distribution of oak cohorts. Plot-maps of live trees were also used to estimate the spatial distribution of canopy disturbances and oak cohorts (Figures 5.4a-i). For the five study sites, there were a total of 173 tree establishment events, and 88 major crown releases). Establishment and major crown releases were evenly divided between single-tree (127) and multiple-tree events (134). Thirty trees were established in the aftermath of stand initiating disturbances at Murphy Tract (1650), Watter Smith State Park (1690), and Wrights Woods (1665). The remainder of the multiple-tree events occurred in smaller patches whose size was estimated by the distances between trees of each cohort.

Table 5.5 shows the size-distribution of multiple-tree gaps and the number of trees involved. The smallest size-classes $\left(\leq 200 \mathrm{~m}^{2}\right)$ are underrepresented because single-tree establishment and overstory-recruitment events could not be assigned a gap-size. Most multipletree events involved cohorts of two trees in small patches $\left(\leq 200 \mathrm{~m}^{2}\right)$; nine events showed gaps $<$ $50 \mathrm{~m}^{2}$. This trend is consistent with the current distribution of canopy gaps (Chapter 4, Table 4.10). However, several larger disturbances $\left(>1000 \mathrm{~m}^{2}\right)$ were identifiable. For example, at Murphy Tract plot 2, three oaks and one red maple were established in 1900 in an opening that 
was at least $57 \mathrm{~m}$ wide (Figure 5.3g). This disturbance also released one 64 year-old chestnut oak. At Wrights Woods, an 1855 tornado released four red oaks $50 \mathrm{~m}$ apart (Figure 5.2d). Interpretation of the spatial distribution of cohorts is subject to several assumptions and precautions discussed in the methods section. Given these precautions, these results suggest the following: 1) about one-half the oaks were established as a single tree and a member of no identifiable cohort; this total includes both stems initially established in the understory, and those that established in gaps 2) 30\% of the oaks reached overstory status individually; 3) more than half the multiple-tree events involved two trees in relatively small openings, $<200 \mathrm{~m}^{2}, 4$ ) nearly 1 in 5 oaks are remnants of large stand-initiating events whose dimensions exceed the size of the study plot.

\section{Discussion}

Components of the disturbance regime. Canopy disturbance rates of the oakdominated stands of this study are remarkably consistent across a broad geographical area and a 300-year time period. Small scale disturbances occur, on average, every three years, while larger events involving more than one tree occur on a 17 year interval. The similarity of canopy disturbance rates was not unexpected. Natural disturbance regimes are strongly correlated with broad geographic patterns of climate, topography, and soils, in the same way that these factors influence the vegetation of a region (Runkle 1990). These landscape-scale factors, in turn, constrain disturbance rates to a fairly narrow and predictable range of values (Runkle 1985).

The consistent pattern of canopy disturbance intervals across time suggests that the causes of these disturbances have remained relatively constant as well. In forests of eastern 
North America, wind and fire are historically the most common agents of canopy disturbance (Runkle 1985, 1990). As a canopy disturbance, fire is more important around the edges of the region in the coniferous forests of the southeast, west, and north (Frost 1998; Duchesne 2000; Wade et al. 2000). In the Ohio Valley and the Appalachian Plateau, however, a highly dissected topography with frequent natural firebreaks limits the size of potential fire compartments (Frost 1998). Lightning is an occasional ignition source, particularly during drought years (Ruffner and Abrams 1998), but low correlations between climate and fire frequency suggest most fires in this region are caused by humans (Sutherland 1997; Wade et al. 2000). Fires most often occur on the forest floor in the dormant season (Sutherland 1997). This, in addition to the absence of fuel accumulation, means that the immediate effects of fires in the region are largely concentrated in the understory. Although there are relatively few long-term fire chronologies for the mixed-oak forests of this study, there is a growing consensus that human use (and misuse) of fire has had a significant impact on forest composition and structure. Prior to European settlement, fire was a significant component of the disturbance regime, and strongly correlated correlated with Native American habitation and land-use patterns (DeVivo 1991; Delcourt and Delcourt 1997; Bonnicksen 2000). Fire return intervals as low as two years (McCarthy et al. 2001) and eight years (Buell et al. 1954; Abrams 2000) have been reported. European settlers used fire for many of the same reasons as native Americans, and fire frequencies remained the same or increased (Sutherland 1997; Van Lear and Waldrop 1989; Abrams 2000; Wade et al. 2000). Since 1900, a fire suppression policy has greatly reduced fire frequency and the annual area burned (Abrams 1992; Wade et al. 2000).

In the study area, major disturbances caused by the physical environment reach perhaps their lowest level of importance for forest types in the eastern United States (Runkle 1990). 
Large wind events such as tornadoes occur but are relatively rare. Since 1885, four F2 and larger tornadoes (winds in excess of $113 \mathrm{mph}$ ) were recorded for both Belmont County, Ohio and Washington County, Pennsylvania (NWS 2001), and two for Harrison County, West Virginia (NWS 2001; NOAA 2001). Most forest turnover is associated with small canopy gaps (Runkle 1982, 1990), and wind is the dominant agent of gap formation (Barden 1981; Romme and Martin 1982; Runkle 1985; Clebsch and Busing 1989). Thus, for example, mean gap size of current-day canopy gaps was $94 \mathrm{~m}^{2}$, and $80 \%$ involved the death of 1-2 trees (Table. 4.10). These values are consistent with the reconstruction of historic gap size distribution using tree ring records and plot maps (Table. 5.5).

High velocity, very localized, and short duration windstorms associated with thunderstorms are the most common form of wind events. Winds and thunderstorms account for $40-70 \%$ of severe weather events in the five study site counties (NCDC 2001). Figure 5.4 shows the probability distribution of severe thunderstorms for the five study areas, as well as southeastern Kentucky and western North Carolina. The likelihood of thunderstorm-associated winds in excess of $57 \mathrm{mph}$ occurring at any point is approximately 2\% between May 20-June 16, and July 18-August 12, increasing to approximately 4\% between June 17 and July 15 (NSSL 2001). These winds tend to create gaps during the growing season when trees are fully leafed out, soils are near saturation, and foliage heavy with recent rain. Wind-caused snaps (bole breakage above the ground line) and tipovers (root balls exposed) made up $46 \%$ and $21 \%$, respectively, of current-day canopy gaps. The preponderance of snaps of larger, codominant oaks (Figure 4.12a), and the absence of any trend in direction of fall are further evidence that strong, local winds are an important cause of tree-fall in these study sites. 
Disturbance agents such as heavy snow and ice storms, lightning, and insect and disease infestations also injure or kill trees. Snag densities (all-site average $3.2 \mathrm{~m}^{2} \mathrm{ha}^{-1}$, Table 4.8) attest to the frequency of these events. Larger trees in uneven-aged stands are particularly vulnerable to snow, ice, and lightning (Carvell et al. 19571; Whitney and Johnson 1984), and their deaths create smaller canopy openings consistent with those created by localized wind events. The effect of the stage of stand development on vulnerability to ice and snow damage is unclear. Abell (1934) found that pole-sized stands with even canopies were more heavily damaged that stands with irregular canopies. In contrast, Downs (1938) found that old-growth stands showed greater damage due to increased crown size, the presence of decay, and inflexibility of older stems. In general, damage is less extensive in oak-hickory forests because these genera have wood that is resistant to breakage (Whitney and Johnson 1984; Rebertus et al. 1997).

Canopy disturbance and oak recruitment. The species composition of the study sites is consistent with a disturbance regime characterized by frequent, small events and less frequent large events, verified in part by the fact that these stands have all endured for at least 300 years. The tree-ring record suggests three modes of oak recruitment that correspond to three levels of canopy disturbance: a) recruitment in large openings after a large stand-initiating disturbance; b) episodic recruitment in canopy gaps that either remain open long enough for stems to reach the overstory without being overtopped from above, or which undergo a repeat disturbance and second release; and c) continuous establishment in the understory and overstory recruitment by means of gap release.

Murphy Tract, Wrights Woods, and Watter Smith State Park originated after large standinitiating disturbances (Chapter 4). At each of these sites, the oldest, even-aged cohorts included trees from both study plots. Growth trends of these trees were distinguished by the absences of 
overstory suppression and major crown releases (Figures 4.7 and 5.1a-b). The absence of shade tolerant tree species in the disturbance-initiated cohort suggests that either the disturbance eliminated them (i.e., fire), or they were present but in small numbers. From limited evidence, it is difficult to estimate the historic frequency of these catastrophic events; however, the ages of the oldest white oak cohorts in this study suggest that the minimum interval is at least 350 years. Oaks also were also recruited via smaller canopy disturbances involving two or more trees that occurred, on average, every 17 years. These trees also reached overstory position without being overtopped. However, in contrast to the even-aged structure resulting from stand initiating events, these disturbances resulted in a spatially and temporally dispersed multi-cohort age structure. Large $\left(>1000 \mathrm{~m}^{2}\right)$ multiple-tree gaps were identified; however, two-tree gaps $\leq 200$ $\mathrm{m}^{2}$ in size were most common.

Oaks were also found that had initiated in the understory in less than free-to-grow conditions. Here early growth rates were consistently less than $1 \mathrm{~mm} \mathrm{yr}^{-1}$ (e.g., Figure 5.2c-f). Annual growth patterns of these trees showed higher total variability than trees that established in large openings and reached the overstory without suppression. As a measure of variability, 10-year running averages of tree-ring width were calculated for all sample oaks, and then compared the ratio of the maximum to minimum 10 -year averages. The average ratio $(\%)$ for trees that initiated in the understory was $17.0 \pm 7.4 \%$. Average ratios for gap origin-gap release, and gap origin-no release trees were $22.5 \pm 8.6 \%$ and $30.2 \pm 11.2 \%$, respectively.

Understory shade and oak recruitment. The length of time these trees survived in the understory varied by their relative shade tolerance. White oaks, the most tolerant of the four oak species of this study, required on average, 90 years to reach the overstory. Tree 2MT15 (Figure 5.2e) is an extreme example of this pattern. Between its earliest ring at dbh (1667) and canopy 
accession (1881), this tree had an average growth rate of $0.54 \mathrm{~mm} \mathrm{yr}^{-1}$. The standard deviation during this time period was $0.12 \mathrm{~mm}$, suggesting that consistently low light levels influenced radial growth more than annual variation in moisture and temperature.

In addition to shade tolerance, this species' ability to withstand being overtopped for long periods is also due to drought tolerance and a growth strategy that favors root growth over shoot growth (Abrams 1990; Lorimer 1993). Seedlings (Rogers 1990), saplings, and pole-sized trees may persist for 60-90 years under a closed canopy (Minckler 1957; 1967; Schlesinger 1978; McGee and Bivens 1984; Graney 1987), and are consistent with the longer residence times found in this study.

Red oak and black oak are generally considered less tolerant of shade than white oak (Burns and Honkala 1990), but the percentage of these species that initiated in understory shade (41\% and 30\%, respectively) were comparable to white oak (37\%, Table 5.4). The 50- year average understory residence times of red oak and black oak in this study exceed most current estimations of these species' ability to survive heavy shade. Like white oak, seedlings of red oak and black oak readily resprout after dieback, and roots may be 30 years older than stems (Merz and Boyce 1956; Johnson 1994; Sander 1990). However, current experience suggests that survival of aboveground portions of seedlings and sprouts, particularly on better sites, is often very low. Red oak seedlings demonstrate a negative carbon balance under a heavy canopy, and seedlings often die once acorn reserves are depleted (Lorimer 1993). Johnson (1994) reported that 8 -year seedling survival of red oak was as low as $20 \%$ when the subcanopy was intact. However in an experiment that removed tall understory vegetation $(>1.5 \mathrm{~m}), 5$-year survival of planted white oak and red oak seedlings was $93 \%$ compared to only $27 \%$ survival on control 
plots (Lorimer et al. 1994). Net height decreased on the control plots because of dieback, but height increased 50-96\% on the understory-removal plots (Lorimer et al. 1994).

Numerous other studies show that understory light levels are critical for survival and growth of all oaks (Carvell and Tryon 1961; Loach 1970), but particularly for red oak, because of this species lower drought and shade tolerance (McGee 1968; Phares 1971; Larsen and Johnson 1998). However, while increasing understory light increases oak seedling growth, competing species such as beech, sugar maple, red maple, and black cherry also benefit. The latter two species may, in fact, gain an advantage over oaks due to greater morphological and physiological plasticity, and the ability to respond more rapidly to changing conditions (Gottschalk 1994; Abrams 1998). Therefore, unless a reduction in the level of understory competition accompanies an increase in light to the understory, the temporary advantage available to oaks may be lost.

In the stands of this study, the existence of numerous oak cohorts and an uneven-aged structure suggest that they were historically maintained by a unique combination of large and small disturbances, high understory light levels, and low levels of understory competition. However, beginning in the 1800 s, conditions changed. Oak replacement largely ceased during the last 200 years at Wrights Woods and Collins Woods. At Wrights Woods, the youngest white oak and red oak date to 1805 and 1852, respectively. At the remaining three study sites, oak replacement continued through the 1800s and mid-1900s, but current understory (seedlingsapling) levels are either low or virtually absent (Tables 4.5 and 4.6). The disturbance interval analysis suggests no appreciable change in the creation-rate of canopy gaps. Thus, the primary change likely lies with the level of understory light and inter-species competition. There are several lines of evidence to support this hypothesis. Presettlement-era dominance of upland 
forests in this region by species more shade tolerant than oak was uncommon outside of mesic and protected environments (Russell 1981; Nowacki and Abrams; Lorimer et al. 1994). Early land surveys attest to a forest dominated by oak species (Chapter 2). Combined importance values for oak species were 1.5-4.5 times greater than IV's for sugar maple, red maple, and beech, and other shade tolerant understory trees (Table 2.1). The one study area for which presettlement forest diameter-distribution data are available shows white oak, and to a lesser degree, black oak well represented in all but the smallest $(10 \mathrm{~cm})$ diameter class, suggesting the presettlement oak component was relatively stable (Figure 2.2).

While a species' presence or absence in one canopy stratum does not necessarily guarantee a similar status in another, the species composition of the oldest surviving trees does strongly suggest low levels of shade tolerant species in the understory of presettlement forests. Sugar maple and beech are potentially as long-lived as white oak (Burns and Honkala 1990), and seed sources of sugar maple, red maple, and beech were surely present. The canopy disturbance regime described in this study — frequent, small, repeat canopy gaps—should facilitate the presence of shade tolerants in the old-growth cohorts (Barden 1980, 1981; Runkle 1985; Canham 1990; Poulson and Platt 1996). Nevertheless, none of the study sites had these species in the oldest cohorts. The oldest sugar maples and beech generally date to the $1850 \mathrm{~s}$, and as late as 1890 at Wrights Woods. At Collins Woods and Wrights Woods, the earliest establishment of shade tolerant species 1850-1900 was concurrent with the cessation of oak establishment.

The change in understory composition signaled by the recruitment of shade tolerant species in the mid-late 1800 s is paralleled by a change in the frequency of oak modes of canopy accession. Figure 5.6 shows a chronology of oak recruitment by historical period. Before 1900, oaks utilized gap origin-no release and understory origin-gap release strategies in roughly equal 
proportions. After 1900, 10 of 14 (71\%) oaks were established in large openings and underwent no overstory suppression. In contrast, only one white oak now in the overstory established in understory shade, and three white oaks originated in a gap and survived being overtopped. These results are influenced by a smaller number of cored trees representing the post 1900 time period, however these trees generally comprise a $100 \%$ inventory of oaks in $15 \mathrm{~cm}$ or greater size-classes.

Evidence from the old-growth oak forests of this study suggests that, for a time, they utilized a relatively constant canopy disturbance rate to replace themselves. Low levels of shade tolerant species in presettlement land surveys, their absence from the old-growth cohorts, their ingrowth in the mid-1800, and the concurrent decline of oak establishment as understory species, all suggest substantial changes in the understory species composition over the time period reviewed. The consequence of understory change was an increase in understory shade, a decline in oak sapling abundance, and a decline in the pool of oak stems that could utilize canopy openings to retain these species share of the canopy. During the past fifty years, considerable effort has been expended to uncover the causes of oak regeneration failures in old-growth and second growth, managed stands. A suite of biotic and abiotic factors have been identified, including erratic seed production (Smith 1993), acorn herbivory by rodents and insects (Marquis et al. 1976), disease (Oak 1993), and deer browse (Marquis 1981; Marquis and Brenneman 1991). Although each factor has led to regeneration failures at certain times and places, they do not account for the frequent failure of oaks to out-compete shade tolerant species even when seedlings are abundant and the overstory removed (Beck and Hooper 1986). In addition, these factors do not adequately account for the regional dimensions of the oak regeneration problem. The results of this study support Lorimer's (1993) hypothesis that the principal bottleneck is 
more a function of the physiological limitations placed on oak advanced regeneration by dense, low overstory shade than low levels of oak germination.

\section{Conclusion}

Because of their antiquity, the old-growth forests of this study provide a valuable source of long-term data on individual tree and stand dynamics of oak forests of this region. These data, in turn, may contribute to a better understanding of the ecological foundations of the oak regeneration problem. Although there was some variation by site and by historical period, there have been no significant changes in canopy disturbance rates for the 300 -year period reviewed. Using a variety of growth strategies and canopy opening-sizes, oak components have been maintained in a relatively stable, uneven-aged condition. However, current sparseness of sapling-size oak advance regeneration suggest that the future oak composition is in question, particularly on better sites. Oaks' ability to persist in the understory for long periods of time constitutes the key difference between the past and present condition of these stands. Average understory residence times of 89 and 54 years for white oak and red oak, respectively, suggest that past understory light levels and the competitive environment allowed oak seedlings and saplings to survive until release. Although there is some historical precedence for these values, few contemporary second-growth forests contain surviving understory oaks of this age, particularly red oak.

These results have implications for the management of oak-dominated old-growth forests, as well as for oak silviculture in general. Most silvicultural prescriptions for oak forests propose even-aged management. The shelterwood system is currently preferred, and this 
system's manipulation of overstory density, understory light levels, and the level of understory competition is consistent with factors that this study has identified as crucial in the development of these old stands. The preference for even-aged systems is, in part, due to the even-aged condition of most second-growth forests, and the difficulty of using an uneven-aged selection system without continuous cultural treatments to control more tolerant species. Yet the variety of growth strategies exhibited by these old trees, and the age structures of these stands suggest that continuous "natural" cultural treatments were in fact an integral component of the historic disturbance regimes of these forests, and the key to establishment and survival of a competitive oak understory, and eventual accession to the overstory.

Changes in the historic fire regime best account for the changes in stand composition and structure suggested by this study. No other form of surface-level disturbance discriminates in favor of oak species and against sugar maple, beech, and other typical understory competitors. Most of the long-term fire chronologies are for areas at the periphery of the central hardwood forest region. These studies suggest a relatively frequent recurrence of low intensity surface fires during presettlement and settlement times; the few studies of oak dominated forests in the study area confirm this. Additional fire chronologies of older forests are a needed area of research. In addition, stem reconstructions of trees that initiated in understory shade would be useful in verifying height growth patterns proposed by this study. 


\section{Acknowledgements}

Dr. Tom Schuler, USDA Forest Service, Parsons, WV, first suggested using FHX-2 software to analyze canopy disturbance frequencies. I also greatly benefited from several thoughtful discussions with him concerning stand dynamics, and the importance of applying historic disturbance rates to contemporary forest management problems. 


\section{Literature cited}

Abell, C. A. 1934. Glaze storms in hardwood forests. J. For. 32: 35-35.

Abrams, M. D. 1990. Adaptations and responses to drought in Quercus species of North America. Tree Physiology 7: 227-238.

Abrams. M. D. 1992. Fire and the development of oak forests. BioScience 42: 346-353.

Abrams, M. D. 1998. The red maple paradox. BioScience 48: 355-364.

Abrams, M. D. 2000. Fire and the ecological history of oak forests in the eastern United States. In Yaussey, D. A., comp. Proceedings: workshop on fire, people, and the central hardwoods landscape. USDA Forest Service, Gen. Tech. Rep. NE-247.

Alverson, W. H., W. Kuhlman, and D. M. Waller. 1994. Wild forests, conservation biology, and public policy. Island Press, Washington, DC.

Baker, W. L. 1992. The landscape ecology of large disturbances in the design and management of nature reserves. Landscape Ecology 7: 181-194.

Barden, L. S. 1980. Tree replacement in a cove hardwood forest of the southern Appalachians. Oikos 35: 16-19.

Barden, L. S. 1981. Forest development in canopy gaps of a diverse hardwood forest of the southern Appalachian mountains. Oikos 37: 205-209.

Beck, D. E. 1970. Effect of competition on survival and height growth of red oak seedlings. USDA Forest Service. Res. Pap. SE-56.

Beck, D. E. and R. M. Hooper. 1986. Development of a southern Appalachian hardwood stand after clearcutting. South. J. Appl. For. 10: 168-172.

Bonnicksen, T. M. 2000. America's ancient forests: from the ice age to the age of discovery. John Wiley \& Sons. New York, NY.

Brubaker, L. B. 1987. Forest disturbance and tree-ring analysis. In Jacoby, G. C., and Hornbeck, J. W., comps. Proceedings of the International Symposium on Ecological Aspects of Tree-ring Analysis, 17-21, August 1986, Tarrytown, NY. U. S. Dept. of Energy, Washington, D. C. pp. 101-118.

Buell, M. F., Buell, H. F., and Small, J. A. 1954. Fire in the history of Mettler's Woods. Bull. Torrey Bot. Club. 81:253-255. 
Burns, R. M. and B. H. Honkala (tech. coords.) 1990. Silvics of North America. Vol 2. Hardwoods. Agriculture Handbook 654. USDA Forest Service, Washington, DC.

Canham, C. D. 1990. Suppression and release during canopy recruitment in Fagus grandifolia. Bull. Torrey Bot. Club. 117: 1-7.

Canham, C. D., Denslow, J. S.,Platt, W. J., Runkle, J. R., Spies, T. A., and White, P. S. 1990. Light regimes beneath closed-canopies and tree-fall gaps in temperate and tropical forests. Can. J. For. Res. 20:620-631.

Canham, C. D., and Burbank, D. H. 1994. Causes and consequences of resource heterogeneity in forests: interspecific variation in light transmission by canopy trees. Can. J. For. Res.

24:337-349.

Carvell, K. L., E. H. Tryon, and R. P. True. 1957. Effects of glaze on the development of Appalachian hardwoods. J. For. 55: 130-132.

Carvell, K. L. and E. H. Tryon. 1961. The effect of environmental factors on the abundance of oak regeneration beneath mature oak stands. For. Sci. 7: 98-105.

Cho, D. S., and Boerner, R. E. 1991. Canopy disturbance patterns and regeneration of Quercus species in two Ohio old-growth forests. Vegetatio 93:9-18.

Clebsch, E. C. and R. T. Busing. 1989. Secondary succession, gap dynamics, and community structure in a southern Appalachian cove forest. Ecology 70: 728-735.

Cook, E. R. 2001. Contributors of the International Tree-Ring Data Bank. IGBP

PAGES/World Center for Paleoclimatology, NOAA/NGDC Paleoclimatology Program, Boulder, CO. <http://www.ngdc.noaa.gov/paleo/ftp-treering.html >

Cutter, B. E., K. E. Lowell, and J. P. Dwyer. 1991. Thinning effects on diameter growth in black and scarlet oak as shown by tree ring analysis. For Ecol. Manage. 43: 1-13.

Dale, M. E. 1968. Growth response from thinning young even-aged white oak stands. USDA Forest Service. Res. Pap. NE-112, Upper Darby, PA.

Dale, M. E. and D. E. Lutz. 1986. A field guide to quantity and value growth of upland oak. USDA Forest Service. Gen. Tech. Rep. NE-114.

Delcourt, H. R. and P. A. Delcourt. 1997. Pre-Columbian native American use of fire on southern Appalachian landscapes. Conservation Biology 11: 1010-1014.

Denslow, J. S. 1980. Patterns of plant species diversity during succession under different disturbance regimes. Oecologia 46: 18-21. 
Denslow, J. S. 1985. Disturbance-mediated coexistence of species. Chapter 17 In Pickett, S. T. A. and P. S. White, eds. The ecology of natural disturbance and patch dynamics. Academic Press, New York, NY.

Downs, A. A. 1938. Glaze damage in the birch-beech-maple-hemlock type of Pennsylvania and New York. J. For. 36: 63-70.

Duchesne, L. C. and B. C. Hawkes. 2000. Fire in northern ecosystems. Chapter 3 In Brown, J. K. and J. K. Smith, eds. Wildland fire in ecosystems: effects of fire on flora. USDA Forest Service. Gen. Tech. Rep. RMRS-42 Vol. 2.

Fajvan, M. A., and Seymour, R. S. 1993. Canopy stratification, age structure, and development of multicohort stands of eastern white pine, eastern hemlock, and red spruce. Can. J. For. Res. 23: 1799-1809.

Frelich, L. E. and L. J. Graumlich. 1994. Age-class distribution and spatial patterns in an oldgrowth hemlock-hardwood forest. Can. J. For. Res. 24: 1939-1947.

Frost, C. C. 1998. Presettlement fire frequency regimes of the United States: a first approximation. Pages 70-81 In Pruden, T. L. and L. A. Brennan, eds. Fire in ecosystem management: shifting the paradigm from suppression to prescription. Tall Timbers Fire Ecology Conference Proceedings, No. 20. Tall Timbers Research Station, Tallahassee, FL.

Gottschalk, K. W. 1994. Shade, leaf growth and crown development of Quercus rubra, Quercus velutina, Prunus serotina and Acer rubrum seedlings. Tree Physiology 14: 735-749.

Graney, D. L. 1987. Ten-year growth of red and white oak crop trees following thinning and fertilization in the Boston Mountains of Arkansas. In Proc. Fourth Biennial Southern Silvicultural Research Conference, Atlanta, Georgia. USDA Forest Service, Southeastern Forest Experiment Station, Asheville, NC.

Greeley, W. B. and W. W. Ashe. 1907. White oak in the southern Appalachians. USDA Forest Service. Circular 105.

Grime, J. P. 1977. Evidence for the existence of three primary strategies in plants and its relevance to ecological and evolutionary theory. Am. Nat. 111: 1169-1194.

Grissino-Mayer, H. D. 1997. FHX-2 User's Manual: software for the analysis of fire history from tree rings. Laboratory of Tree-ring Research, University of Arizona, Tuscon, AZ.

Grissino-Mayer, H. D., Holmes, R. L., and Fritts, H. C. 1997. The international tree-ring data bank program library version 2.1 user's manual. Laboratory of Tree-Ring Research, Univ. of Arizona, Tuscon, AZ. 
Johnson, P. S. 1994. The silviculture of northern red oak. Pp. 33-68 In Isebrands, J. G, R. E. Dickson, comps. Biology and silviculture of northern red oak in the north central region: a synopsis. USDA Forest Service. Gen. Tech. Rep. NC-173.

Larsen, D. R. and P. S. Johnson. 1998. Linking the ecology of natural oak regeneration to silviculture. For. Ecol. Manage. 106: 1-7.

Loach, K. 1970. Shade tolerance in tree seedlings. II. Growth analysis of plants raised under artificial shade. New Phytol 69: 607-621.

Lorimer, C. G. 1980. Age structure and disturbance history of a southern Appalachian virgin forest. Ecology 61: 1169-1184.

Lorimer, C. G. 1993. Causes of the oak regeneration problem. Pp. 14-39 In Loftis, D. L. and C. E. McGee, eds. Oak regeneration: serious problems, practical recommendations. USDA Forest Service Res. Pap. NE-356.

Lorimer, G. G.,L. E. Frelich, and E. V. Nordheim. 1988. Estimating gap origin probabilities for canopy trees. Ecology 69: 778-785.

Lorimer, C. G. and L. E. Frelich. 1989. A methodology for estimating canopy disturbance frequency and intensity in dense temperate forests. Can. J. For. Res. 19: 651-663.

Lorimer, C. G., J. W. Chapman, and W. D. Lambert. 1994. Tall understory vegetation as a factor in the poor development of oak seedlings beneath mature stands. J. Ecol. 82: 227-237.

Martin, W. H. 1975. The Lilley Cornett Woods: a stable mixed mesophytic forest in Kentucky. Botanical Gazette 136: 171-183.

McCarthy, B. C., C. J. Small, and D. L. Rubino. 2001. Composition, structure and dynamics of Dysart Woods, an old-growth mixed mesophytic forest of southeastern Ohio. For. Ecol.

Manage. 140: 193-213.

McGee, C. E. 1968. Northern red oak seedling growth varies by light intensity and seed source. USDA Forest Service Res. Note SE-90.

McGee, C. E. 1984. Loss of Quercus spp. dominance in an undisturbed old-growth forest. Journal of the Elisha Mitchell Scientific Society. 102: 10-15.

McGee, C. E. and D. L. Bivens. 1984. A billion overtopped white oak-assets or liabilities? South. J. Appl. For. 8:216-220.

Marquis, D. A. 1981. The effect of deer browsing on timber production in Allegheny hardwood forests of northwestern Pennsylvania. USDA Forest Service. Res. Pap. NE-475. 
Marquis, D. A, P. L. Eckert, and B. A. Roach. 1976. Acorn weevils, rodents, and deer all contribute to oak regeneration difficulties in Pennsylvania. USDA Forest Service. Res. Pap. NE-356.

Marquis, D. A. and R. Brenneman. 1991. The impact of deer on forest vegetation in Pennsylvania. USDA Forest Service. Gen. Tech. Rep. NE-65.

Merz, R. W. and S. G. Boyce. 1956. Age of oak “seedlings.” J. For. 54: 774-775.

Minckler, L. S. 1957. Response of pole-sized white oak trees to release. J. For. 55: 814-815.

Minckler, L. S. 1967. Release and pruning can improve growth and quality of white oak. J. For. 65: 654B655.

National Climate Data Center. 2001. Storm events: query output.

$<$ http://www4.ncdc.noaa.gov/cgi-win/wwcgi.dll?wwevent $\sim$ storms $>$

National Oceanic and Atmospheric Administration. 2001. Fugita tornado intensity scale.

$<$ http://www.outlook.noaa.gov.tornadoes/fugita.htm>

National Severe Storm Laboratory. 2001. Severe thunderstorm climatology.

$<$ http://www.nssl.noaa.gov/hazard/hazardmap.html $>$

National Weather Service. 2001. How many significant tornadoes have you had in your county? $<$ http://www.nws.noaa.gov/er/pit/sigtor.htm>

Nowacki, G. J. and M. D. Abrams. 1997. Radial-growth averaging criteria for reconstructing disturbance histories from presettlement-origin oaks. Ecol. Monogr. 67: 225-249.

Nyland, R. D. 1996. Silviculture: concepts and applications. McGraw Hill, New York, NY.

Oak, S. W. 1993. Insects and diseases affecting oak regeneration. Pp. 105-111 In Loftis, D. L. and C. E. McGee, eds. Oak regeneration: serious problems, practical recommendations. USDA Forest Service Res. Pap. NE-356.

Oliver, C. D. and B. C. Larsen. 1996. Forest stand dynamics. John Wiley \& Sons, New York, NY.

Parker, G. R., D. J. Leopold, and J. K. Eichenberger. 1985. Tree dynamics in an old-growth, deciduous forest. For. Ecol. Manage. 11: 31-57.

Phares, R. E. 1972. Growth of red oak (Quercus rubra L.) seedlings in relation to light and nutrients. Ecology 52: 669-672.

Poulson, T. L. and W. J. Platt. 1996. Replacement patterns of beech and sugar maple in Warren Woods, Michigan. Ecology 77: 1234-1253. 
Phipps, R. L. 1982. Comments on interpretation of climatic information from tree rings, eastern North America. Tree-Ring Bulletin. 42:11-22.

Rebertus. A. J., S. R. Shifley, R. H. Richards, and L. M. Roovers. 1997. Ice storm damage to an old-growth oak-hickory forest in Missouri. Am. Midl. Nat. 137: 48:61.

Rogers, R. 1990. Quercus alba L., white oak. In Burns, R. M. and B. H. Honkala (tech. coords.). Silvics of North America. Vol 2. Hardwoods. Agriculture Handbook 654. USDA Forest Service, Washington, DC.

Romme, W. H., and Martin, W. M. 1982. Natural disturbance by tree-falls in an old-growth mixed mesophytic forest: Lilly Cornett Woods, Kentucky. In Muller, R. N., ed. Proceedings, $4^{\text {th }}$ Central Hardwood Forest Conference, Univ. of Kentucky, Lexington, KY. pp. 367-383.

Rubino, D. L., and B. C. McCarthy. 2001. Contributors of the International Tree-Ring Data Bank. IGBP PAGES/World Center for Paleoclimatology, NOAA/NGDC Paleoclimatology Program, Boulder, CO. <http://www.ngdc.noaa.gov/paleo/ftp-treering.html >

Ruffner, C. M. and M. D. Abrams. 1998. Lightning strikes and resultant fires from archival (1912-1917) and current (1960-1997) information in Pennsylvania. J. Torrey Bot. Soc. 125: $249-252$.

Runkle, J. R. 1982. Patterns of disturbance in some old-growth mesic forests of the eastern United States. Ecology 63: 1533-1546.

Runkle, J. R. 1985. Disturbance regimes in temperate forests. Chapter 2 In Pickett, S. T. A. and P. S. White, eds. The ecology of natural disturbance and patch dynamics. Academic Press, New York, NY.

Runkle, J. R. 1990. Gap dynamics in an Ohio Acer-Fagus forest and speculations on the geography of disturbance. Can. J. For. Res. 20: 632-641.

Sander, I. L. 1990. Quercus rubra L., northern red oak. In Burns, R. M. and B. H. Honkala (tech. coord.). Silvics of North America. Vol 2. Hardwoods. Agriculture Handbook 654. USDA Forest Service, Washington, DC.

Schlesinger, R. C. 1978. Increased growth of released white oak poles continues through two decades. J. For. 76: 726-727.

Schuler, T. M. 1998. Patterns of oak regeneration in a central Appalachian forest. Ph.D. dissertation. Purdue University, West Lafayette, IN.

Schuler, T. M. and M. A. Fajvan. 1999. Understory tree characteristics and disturbance history of a central Appalachian forest prior to old-growth harvesting. USDA Forest Service. Res. Pap. NE-710. 
Smith, D. W. 1993. Oak regeneration: the scope of the problem. Pp. 40-52 In Loftis, D. L. and C. E. McGee, eds. Oak regeneration: serious problems, practical recommendations. USDA Forest Service Res. Pap. NE-356.

Stokes, M. A., and Smiley, T. L. 1968. An introduction to tree-ring dating. Univ. Arizona Press, Tuscon, AZ.

Sutherland, E. K. 1997. History of fire in a southern Ohio second-growth mixed oak forest. In. Pallardy, S. G., R. A. Cecich, H. G. Garrett, and P. S. Johnson, eds. Proc. $11^{\text {th }}$ central hardwood forest conference. USDA Forest Service. Gen Tech. Rep. NC-188.

Van Lear, D. H. and T. A. Waldrop. 1989. History, uses, and effects of fire in the Appalachians. USDA Forest Service, Gen. Tech. Rep. SE-54.

Wade, D. D., B. L. Brock, P. H. Brose, J. B. Grace, G. A. Hock, and W. A. Patternson III. 2000. Fire in eastern ecosystems. Chapter 4 In Brown, J. K. and J. K. Smith, eds. Wildland fire in ecosystems: effects of fire on flora. USDA Forest Service. Gen. Tech. Rep. RMRS-42 Vol. 2.

Ward, J. S. and G. R. Stephens. 1994. Crown class transition rates of maturing northern red oak (Quercus rubra L.). For. Sci. 40: 221-237.

Weitzman, S. and G. R. Trimble. 1957. Some natural factors that govern the management of oaks. USDA Forest Service. Res. Pap. NE-88.

Whitney, H. E. and W. C. Johnson. 1984. Ice storms and forest succession in southwestern Virginia. Bull. Torrey Bot. Club. 4: 429-437.

Yetter, T. C., and Runkle, J. R. 1986. Height growth rates of canopy tree species in southern Appalachian gaps. Castanea 51:157-167. 
Table 5.1 Disturbance intervals (yrs), 1700-1990, for five oak-dominated old-growth forests in Ohio, Pennsylvania, and West Virginia, and three additional sites in Ohio, Kentucky, and North Carolina. Disturbances are determined by radial growth averaging, $\% \mathrm{GC}>25 \%$. Only sample trees $>150$ years old are represented. Data are modeled by a 2-parameter Weibull distribution.

a) Single-tree events

\begin{tabular}{|c|c|c|c|c|c|}
\hline Site & $\begin{array}{c}\quad 0.875 \\
\text { Exceedance } \\
\text { Probability }\end{array}$ & $\begin{array}{c}0.500 \\
\text { Weibull } \\
\text { Median }\end{array}$ & $\begin{array}{l}\quad 0.125 \\
\text { Exceedance } \\
\text { Probability }\end{array}$ & $\begin{array}{l}\text { Number } \\
\text { of } \\
\text { intervals }\end{array}$ & $\begin{array}{c}\text { Number } \\
\text { of } \\
\text { trees }\end{array}$ \\
\hline Wrights Woods (PA) & 0.6 & 3.0 & 8.7 & 67 & 17 \\
\hline Murphy Tract (WV) & 0.5 & 2.2 & 6.2 & 93 & 26 \\
\hline Horners Woods (WV) & 0.6 & 2.8 & 7.3 & 75 & 24 \\
\hline Watter Smith State Park (WV) & 0.8 & 3.4 & 8.9 & 60 & 14 \\
\hline Collins Woods $(\mathrm{OH})$ & 1.1 & 3.8 & 9.0 & 59 & 14 \\
\hline Dysart Woods, $(\mathrm{OH})^{1}$ & 1.0 & 4.2 & 10.9 & 51 & 10 \\
\hline Lilly Cornett Woods $(\mathrm{KY})^{1}$ & 0.6 & 2.1 & 5.3 & 105 & 30 \\
\hline Joyce Kilmer Wilderness (NC) ${ }^{1}$ & 0.5 & 2.4 & 7.2 & 80 & 29 \\
\hline Average & $0.7 \pm 0.2$ & $3.0+0.8$ & $7.9 \pm 1.8$ & 74 & 21 \\
\hline
\end{tabular}

b) Multiple-tree events

\begin{tabular}{|c|c|c|c|c|c|}
\hline Site & $\begin{array}{c}\quad 0.875 \\
\text { Exceedance } \\
\text { Probability } \\
\end{array}$ & $\begin{array}{c}0.500 \\
\text { Weibull } \\
\text { Median }\end{array}$ & $\begin{array}{c}\quad 0.125 \\
\text { Exceedance } \\
\text { Probability } \\
\end{array}$ & $\begin{array}{l}\text { Number } \\
\text { of } \\
\text { intervals }\end{array}$ & $\begin{array}{c}\text { Number } \\
\text { of } \\
\text { trees }\end{array}$ \\
\hline Wrights Woods (PA) & 11.6 & 20.7 & 30.4 & 13 & 17 \\
\hline Murphy Tract (WV) & 6.3 & 14.2 & 24.5 & 17 & 26 \\
\hline Horners Woods (WV) & 6.8 & 14.8 & 25.0 & 16 & 24 \\
\hline Watter Smith State Park (WV) & 7.5 & 15.9 & 26.2 & 14 & 14 \\
\hline Collins Woods $(\mathrm{OH})$ & 5.8 & 14.9 & 27.7 & 14 & 14 \\
\hline Dysart Woods, $(\mathrm{OH})^{1}$ & 12.3 & 21.2 & 29.5 & 13 & 10 \\
\hline Lilly Cornett Woods $(\mathrm{KY})^{1}$ & 7 & 14.6 & 23.6 & 18 & 30 \\
\hline Joyce Kilmer Wilderness (NC) ${ }^{1}$ & 11.9 & 19.8 & 27.8 & 13 & 29 \\
\hline Average & $8.6 \pm 2.8$ & $17.0+3.0$ & $26.8+2.4$ & 15 & 21 \\
\hline
\end{tabular}

${ }^{1}$ oak chronologies from International Tree-ring Data Bank 
Table 5.2 Disturbance intervals (yrs) for three historical periods: 1700-1800, 1801-1900, and 1901-1990 for five old-growth sites in Ohio, Pennsylvania, and West Virginia, and three additional sites in Ohio, Kentucky, and North Carolina. Disturbances are determined by radial growth averaging, \%GC $>25 \%$. Only sample trees $>150$ years old are represented. Mean disturbance intervals are compared for three historical periods: 1700-1800, 1801-1900, and 1900-1990. Means are compared using t-tests for equal and unequal variances.

a) Single tree events $\quad$ Mean disturbance interval (yrs. $)^{2}$

\begin{tabular}{|c|c|c|c|c|c|c|}
\hline Site & $\begin{array}{c}\text { Presettlement } \\
1700-1800\end{array}$ & $\mathrm{n}$ (trees) & $\begin{array}{l}\text { Settlement } \\
1801-1900\end{array}$ & $\mathrm{n}$ (trees) & $\begin{array}{c}\text { Modern } \\
1901-1990\end{array}$ & $\mathrm{n}$ (trees) \\
\hline Wrights Woods (PA) & $6.6 \mathrm{a}$ & 11 & $3.1 \mathrm{~b}$ & 17 & $3.5 \mathrm{ab}$ & 17 \\
\hline Murphy Tract (WV) & $3.1 \mathrm{ab}$ & 20 & $2.3 \mathrm{a}$ & 26 & $4.2 b$ & 26 \\
\hline Horners Woods (WV) & 7.1a & 7 & $3.0 \mathrm{~b}$ & 24 & $2.4 \mathrm{~b}$ & 24 \\
\hline Watter Smith State Park (WV) & $5.4 \mathrm{a}$ & 6 & $3.3 \mathrm{a}$ & 14 & $4.6 \mathrm{a}$ & 14 \\
\hline Collins Woods $(\mathrm{OH})$ & $6.3 \mathrm{a}$ & 10 & $4.4 \mathrm{~b}$ & 14 & $3.8 \mathrm{~b}$ & 14 \\
\hline Dysart Woods, $(\mathrm{OH})^{1}$ & $5.2 \mathrm{a}$ & 7 & $4.6 \mathrm{a}$ & 10 & $7.6 \mathrm{a}$ & 10 \\
\hline Lilly Cornett Woods (KY) ${ }^{1}$ & $2.2 \mathrm{a}$ & 30 & $2.3 \mathrm{ab}$ & 30 & $3.4 \mathrm{~b}$ & 30 \\
\hline Joyce Kilmer Wilderness (NC) & $2.7 \mathrm{a}$ & 29 & $3.3 \mathrm{a}$ & 29 & $5.1 \mathrm{a}$ & 29 \\
\hline Average - all sites & $4.2+3.1$ & & $3.6 \pm 2.0$ & & $3.7 \pm 1.9$ & \\
\hline
\end{tabular}

b) Multiple tree events

\begin{tabular}{|c|c|c|c|c|c|c|}
\hline Site & $\begin{array}{c}\text { Presettlement } \\
1700-1800\end{array}$ & $\mathrm{n}$ (trees) & $\begin{array}{l}\text { Settlement } \\
1801-1900\end{array}$ & $\mathrm{n}$ (trees) & $\begin{array}{c}\text { Modern } \\
1901-1990\end{array}$ & $\mathrm{n}$ (trees) \\
\hline Wrights Woods (PA) & $17.0 \mathrm{a}$ & 11 & $17.3 \mathrm{a}$ & 17 & $18.8 \mathrm{a}$ & 17 \\
\hline Murphy Tract (WV) & $12.3 \mathrm{a}$ & 20 & $12.0 \mathrm{a}$ & 26 & $22.3 \mathrm{a}$ & 26 \\
\hline Horners Woods (WV) & $17.0 \mathrm{a}$ & 7 & $14.4 \mathrm{a}$ & 24 & $15.8 \mathrm{a}$ & 24 \\
\hline Watter Smith State Park (WV) & $13.2 \mathrm{a}$ & 6 & $18.0 \mathrm{a}$ & 14 & 19.1a & 14 \\
\hline Collins Woods $(\mathrm{OH})$ & $14.0 \mathrm{a}$ & 10 & $13.2 \mathrm{a}$ & 14 & $15.2 \mathrm{a}$ & 14 \\
\hline Dysart Woods, $(\mathrm{OH})^{1}$ & $21.2 \mathrm{a}$ & 7 & $20.2 \mathrm{a}$ & 10 & $22.3 \mathrm{a}$ & 10 \\
\hline Lilly Cornett Woods (KY) ${ }^{1}$ & $10.1 \mathrm{a}$ & 30 & $14.5 \mathrm{a}$ & 30 & $14.4 \mathrm{a}$ & 30 \\
\hline Joyce Kilmer Wilderness (NC) ${ }^{1}$ & $15.8 \mathrm{a}$ & 29 & $21.7 \mathrm{a}$ & 29 & $20.7 \mathrm{a}$ & 29 \\
\hline Average - all sites & $14.4+8.1$ & & $17.5 \pm 8.5$ & & $18.4+7.4$ & \\
\hline
\end{tabular}

\footnotetext{
${ }^{\mathrm{I}}$ Tree-ring chronologies from International Tree Ring Library Data Base.

${ }^{2}$ Means in the same row with different letters are significantly different.
} 
Table 5.3 Summary of growth trends and origin of canopy oak trees based on early growth rates and identification of major release events (GC\% > 100\%) using radial growth averaging $(\mathrm{N}=177)$.

\begin{tabular}{|c|c|c|c|c|c|c|}
\hline \multirow{2}{*}{ Site } & \multirow{2}{*}{$\begin{array}{c}\text { Origin- } \\
\text { growth trend }\end{array}$} & \multicolumn{4}{|c|}{ Species } & \multirow{2}{*}{$\begin{array}{c}\text { Site } \\
\text { Totals } \\
\end{array}$} \\
\hline & & Quealb & Quepri & Querub & Quevel & \\
\hline \multirow{3}{*}{$\begin{array}{l}\text { Wrights } \\
\text { Woods }\end{array}$} & Gap origin-no release & 3 & & 2 & & 5 \\
\hline & Under origin-gap release & 4 & & 2 & & 6 \\
\hline & Gap origin-gap release & 5 & & 1 & & 6 \\
\hline \multirow{3}{*}{$\begin{array}{l}\text { Murphy } \\
\text { Tract }\end{array}$} & Gap origin-no release & 17 & 1 & 5 & 9 & 32 \\
\hline & Under origin-gap release & 17 & 3 & 2 & 3 & 25 \\
\hline & Gap origin-gap release & 4 & & & 1 & 5 \\
\hline \multirow{3}{*}{$\begin{array}{l}\text { Horners } \\
\text { Woods }\end{array}$} & Gap origin-no release & 10 & 2 & & 11 & 23 \\
\hline & Under origin-gap release & 6 & 3 & & 6 & 15 \\
\hline & Gap origin-gap release & 3 & 2 & 1 & 2 & 8 \\
\hline \multirow{3}{*}{$\begin{array}{l}\text { Watter } \\
\text { Smith SP }\end{array}$} & Gap origin-no release & 9 & & 2 & 3 & 14 \\
\hline & Under origin-gap release & 1 & 3 & 5 & 2 & 11 \\
\hline & Gap origin-gap release & 1 & & 1 & & 2 \\
\hline \multirow{3}{*}{$\begin{array}{l}\text { Collins } \\
\text { Woods }\end{array}$} & Gap origin-no release & 7 & & 4 & & 11 \\
\hline & Under origin-gap release & 6 & & 3 & & 9 \\
\hline & Gap origin-gap release & & & 1 & & 1 \\
\hline \multirow{3}{*}{$\begin{array}{l}\text { Species } \\
\text { totals }\end{array}$} & Gap origin-no release & 46 & 3 & 13 & 23 & 85 \\
\hline & Under origin-gap release & 34 & 9 & 12 & 11 & 66 \\
\hline & Gap origin-gap release & 13 & 2 & 4 & 3 & 22 \\
\hline
\end{tabular}


Table 5.4 Mean understory residence time ${ }^{1}$ (MRT) and dbh (inside bark) at canopy accession for four oak species $(\mathrm{N}=88)$. Trees included are those classified gap origin-gap release, and understory origin-gap release.

\begin{tabular}{|c|c|c|c|c|c|c|c|}
\hline \multirow{2}{*}{ Species } & & Wrights & Murphy & Horners & Watter & Collins & Species \\
\hline & & & & & & & \\
\hline \multirow{3}{*}{ white oak } & MRT (yrs) & 92 & 84 & 93 & 94 & 90 & $89 \pm 48$ \\
\hline & $\operatorname{dib}(\mathrm{cm})$ & 15.9 & 11.8 & 23.9 & 17.2 & 13.3 & $13.3 \pm 8.3$ \\
\hline & $\mathrm{N}$ & 9 & 21 & 9 & 2 & 6 & \\
\hline \multirow{3}{*}{ chestnut oak } & MRT (yrs) & & 31 & 44 & 33 & & $38 \pm 20$ \\
\hline & $\operatorname{dib}(\mathrm{cm})$ & & 5.0 & 7.8 & 4.7 & & $6.2 \pm 5.0$ \\
\hline & $\mathrm{N}$ & & 3 & 6 & 3 & & \\
\hline \multirow{3}{*}{ no. red oak } & MRT (yrs) & 39 & 61 & 65 & 58 & 52 & $54 \pm 24$ \\
\hline & $\operatorname{dib}(\mathrm{cm})$ & 7.1 & 11.4 & 17.1 & 14.0 & 10.6 & $11.7 \pm 6.9$ \\
\hline & $\mathrm{N}$ & 3 & 3 & 1 & 5 & 4 & \\
\hline \multirow{3}{*}{ black oak } & MRT (yrs) & & 44 & 48 & 70 & & $50 \pm 25$ \\
\hline & $\operatorname{dib}(\mathrm{cm})$ & & 6.7 & 9.4 & 18.9 & & $10.0 \pm 6.8$ \\
\hline & $\mathrm{N}$ & & 4 & 8 & 2 & & \\
\hline
\end{tabular}

${ }^{1}$ Mean understory residence time (MRT) defined as time between initial recruitment (earliest ring) and canopy accession ( $\% \mathrm{GC} \geq 100 \%)$. Trees that initiate in gaps with no major releases are not included.

Table 5.5. Frequency of patch-size and number of trees involved/patch for synchronous establishment and major release events. Large, stand-initiating disturbances that exceed plot dimensions are not included

\begin{tabular}{ccccccc}
\hline $\begin{array}{c}\text { Event } \\
\text { type }\end{array}$ & Single-tree & \multicolumn{5}{c}{ Multiple-tree patch size-class $\left(\mathrm{m}^{2}\right)$} \\
\hline & & $<100$ & $100-200$ & $200-500$ & $500-1000$ & $>1000$ \\
Establishment & 76 & 10 & 5 & 5 & 3 & 3 \\
Major release & 51 & 8 & 6 & 2 & 2 & 3 \\
Total & 127 & 18 & 11 & 7 & 5 & 6 \\
& & \multicolumn{7}{c}{ Number of patches } \\
Establishment & 76 & 20 & 11 & 8 & 8 & 7 \\
Major release & 51 & 16 & 6 & 13 & 7 & 9 \\
Total & 127 & 36 & 17 & 21 & 15 & 16 \\
\hline
\end{tabular}


Figure 5.1. Location of five oak-dominated, old-growth study sites (white diamonds), and three additional oak sites with tree-ring data obtained from International Tree-ring Data Bank (blue diamonds).

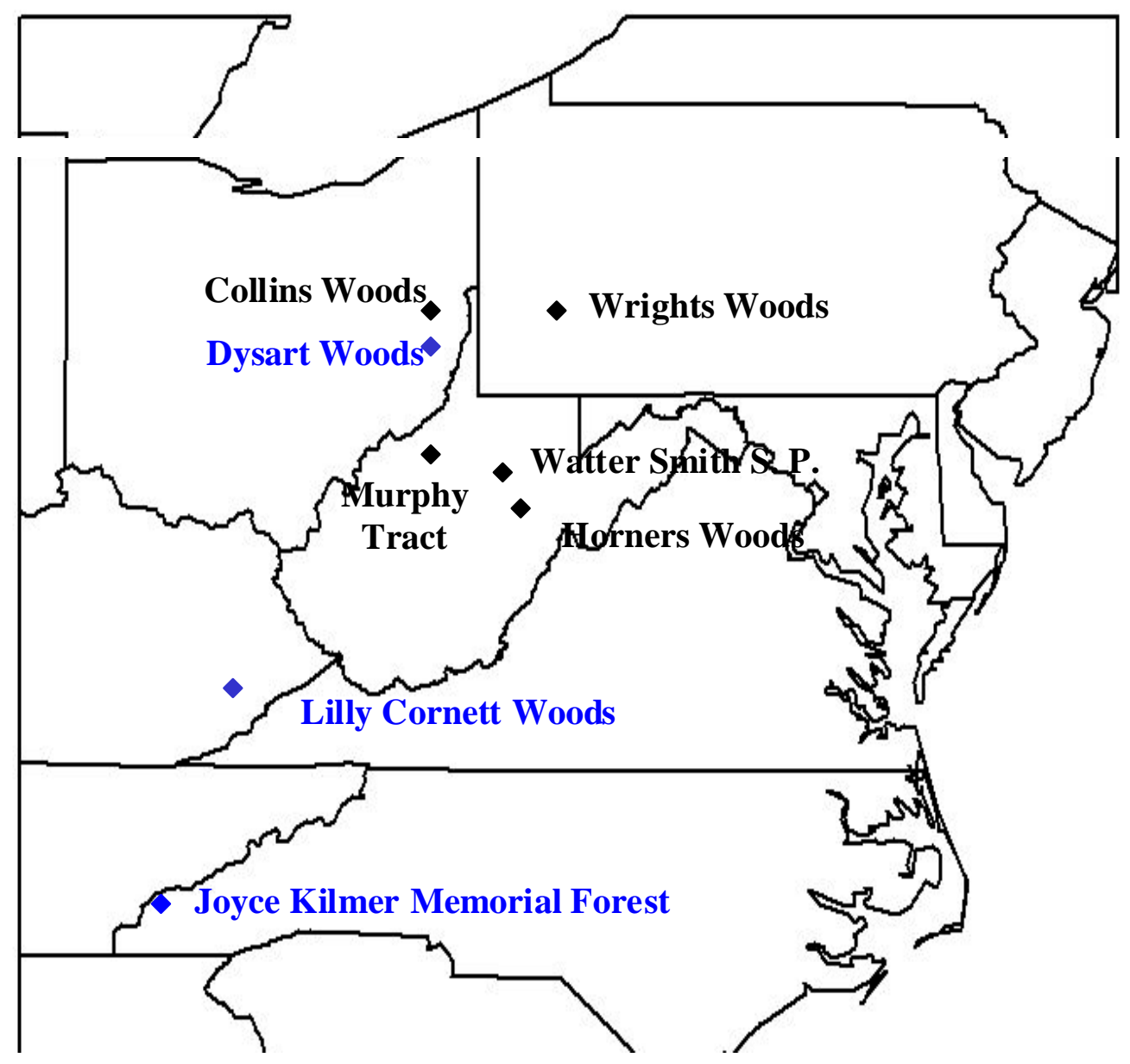


Figure 5.2. Examples of suggested classification of tree-origin based on early growth rates and presence /absence of a major crown release $(\% \mathrm{GC} \geq 100 \%)(\mathrm{dib}=\mathrm{dbh}$ inside bark $)$.

\section{Type 1 - Gap origin-no major release.}

a) tree with average early growth followed by a slightly increasing trend, and no major releases.

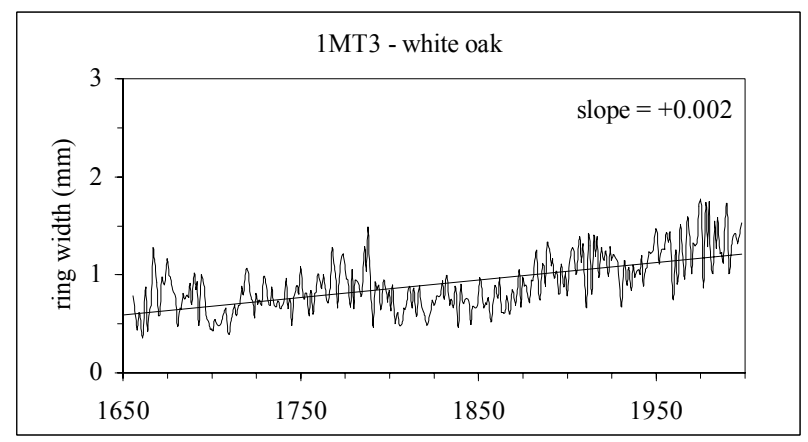

b) tree with above-average early growth and a flat or slightly decreasing trend, and no major releases.

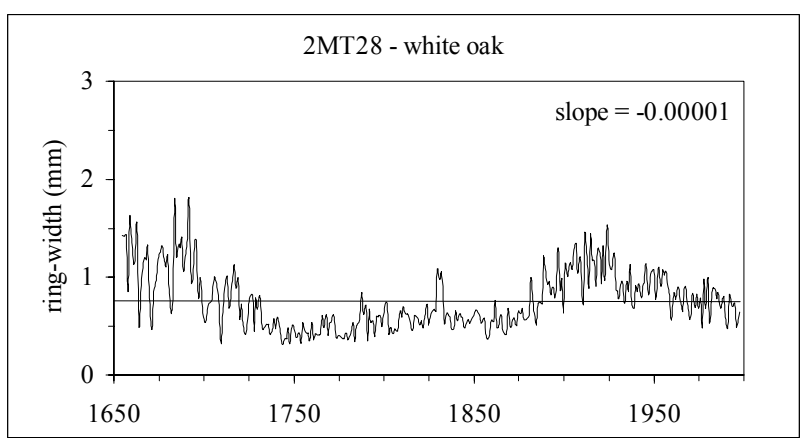

\section{Type 2 - Gap origin-gap release}

c) tree with above-average early growth followed by suppression, and subsequent major release.

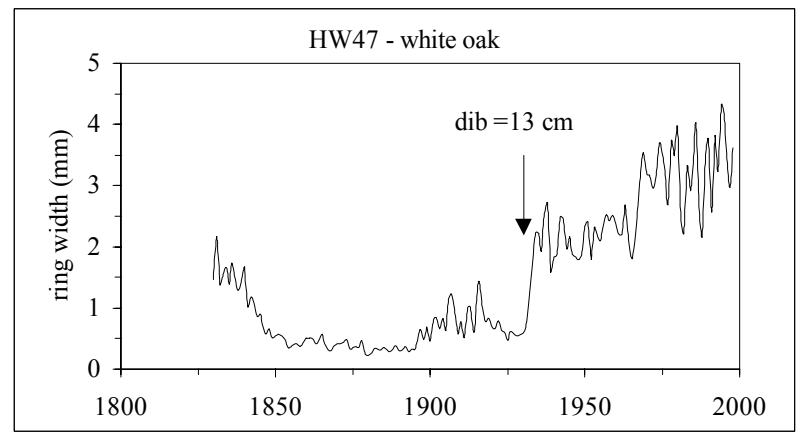

d) tree with above-average early growth followed by release, suppression, and a second major release.

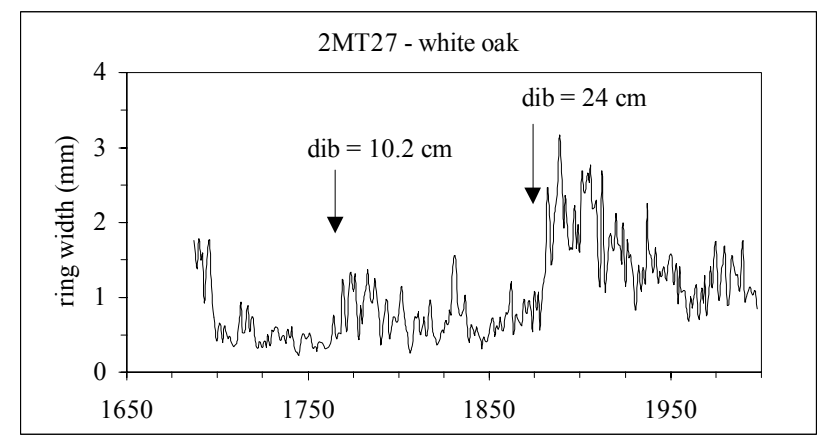

Type 3 - Understory origin-gap release

e) tree with below-average early growth before major release and overstory accession.

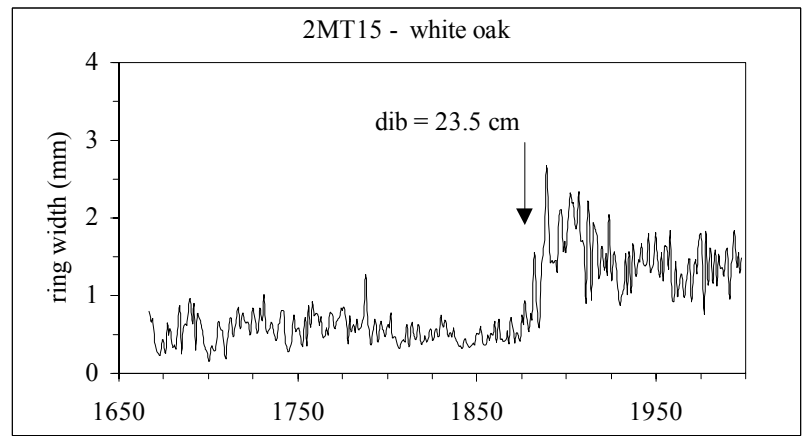

f) tree with below-average early growth and two major releases before overstory accession.

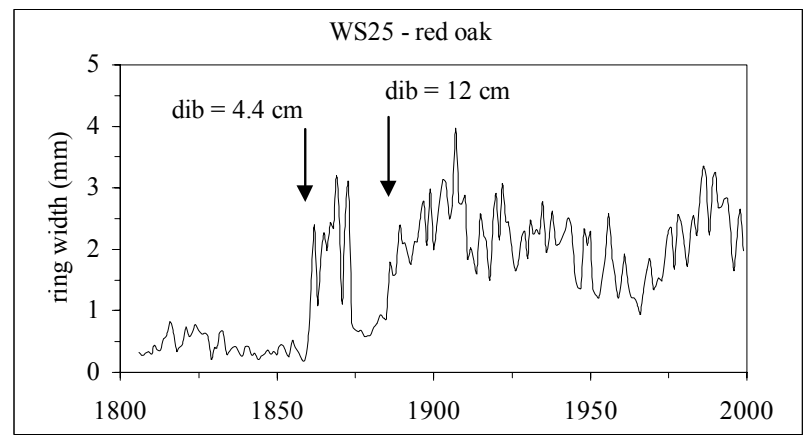


Figure 5.3. Examples of red oaks and black oaks that initiated in the understory and survived for an extended period until overhead release and canopy accession. Arrows indicate understory residence time (yrs.) prior to final overhead release ( $\% \mathrm{GC} \geq 100 \%)$.
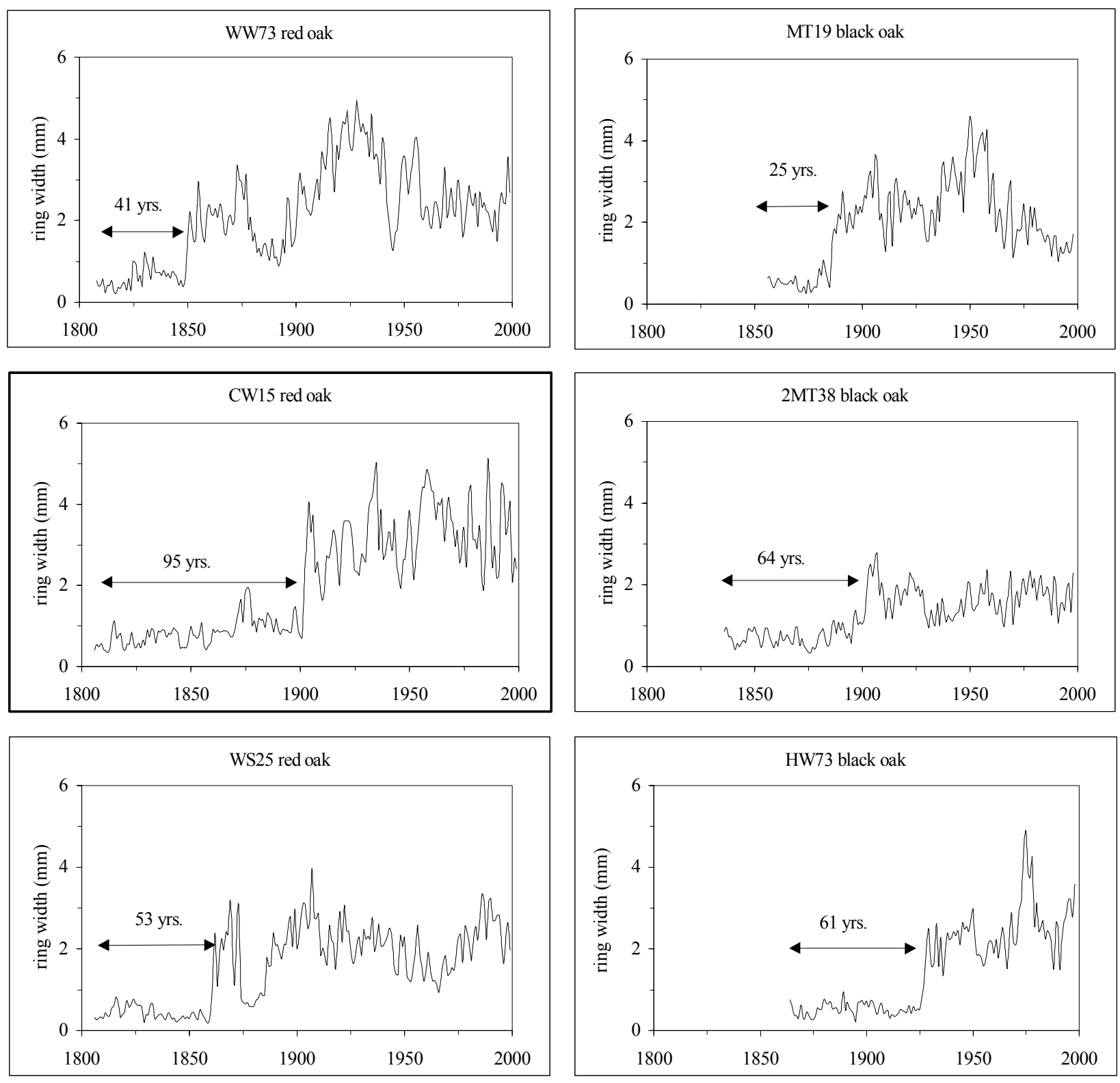
Figure 5.4a. Collins Woods Plot 1 dbh-age and release dates, and cohorts of cored canopy trees.

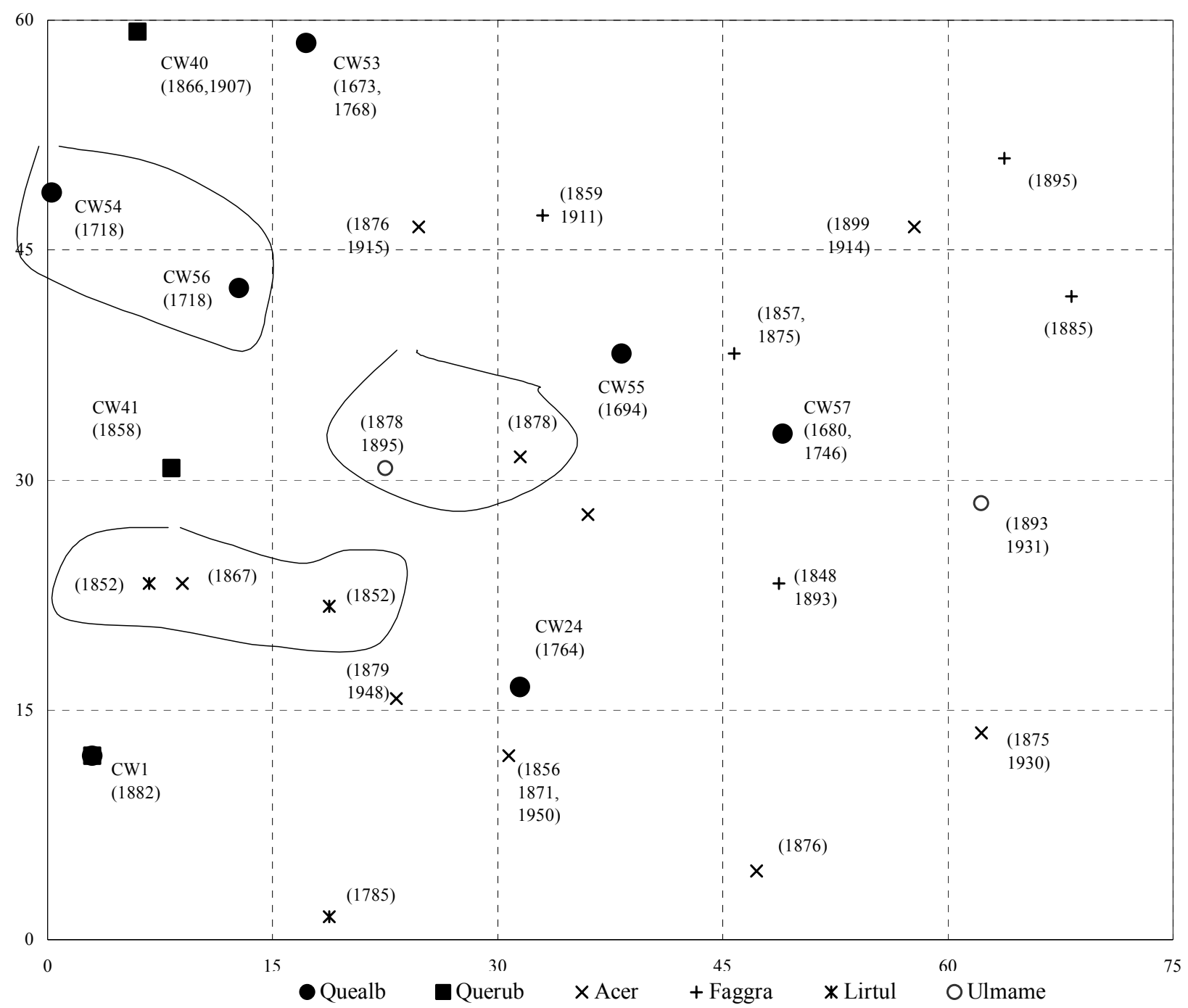


Figure 5.4b. Collins Woods Plot 2 dbh-age and releasedates, and cohorts of cored canopy trees

Quealb
Querub
$\times$ Acer
$\Delta$ Carya
+ Faggra
$\diamond$ Lirtul
O Oxyarb

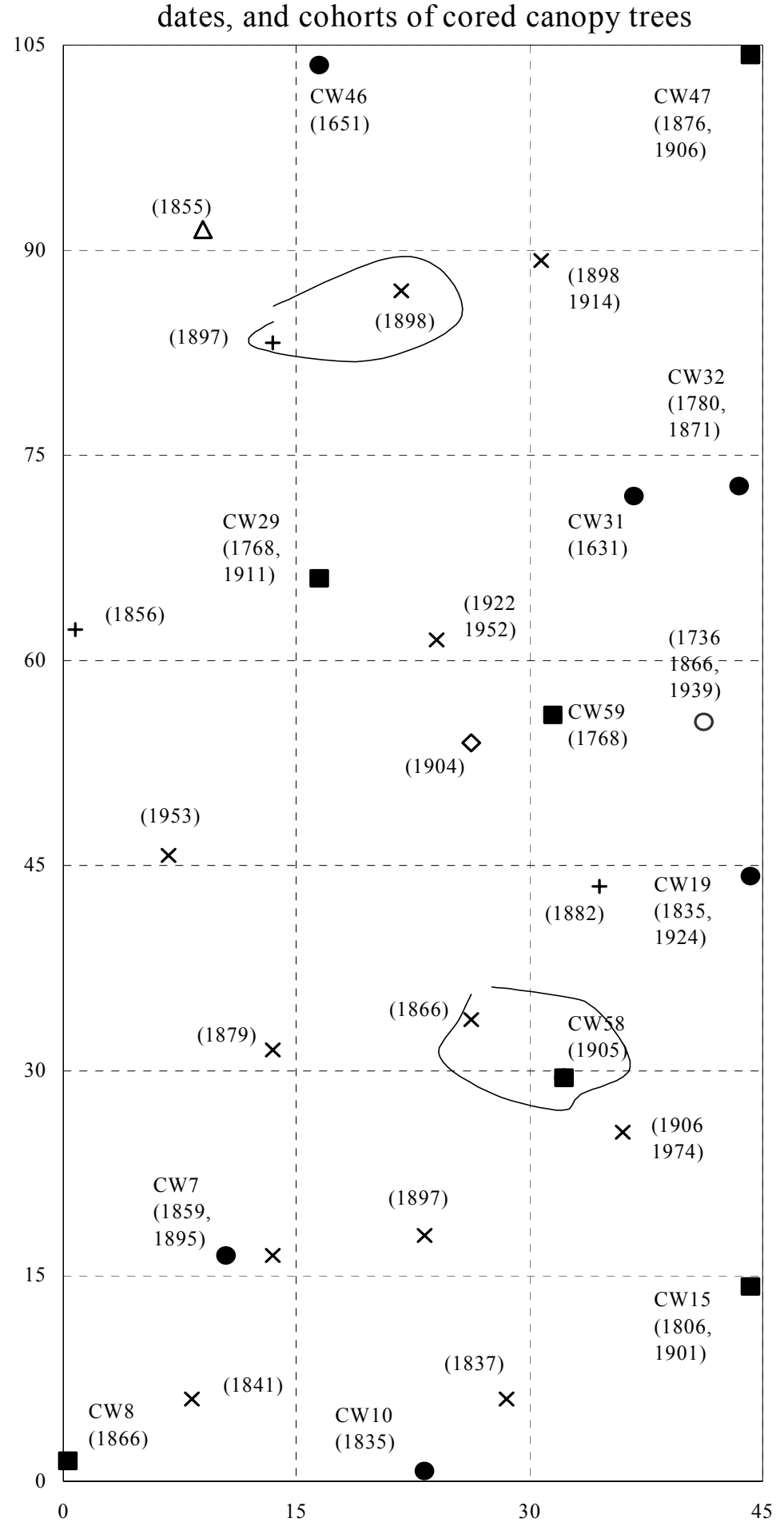


Figure 5.4c. Wrights Woods Plot 1, dbh-age and release-dates, and cohorts of cored canopy trees

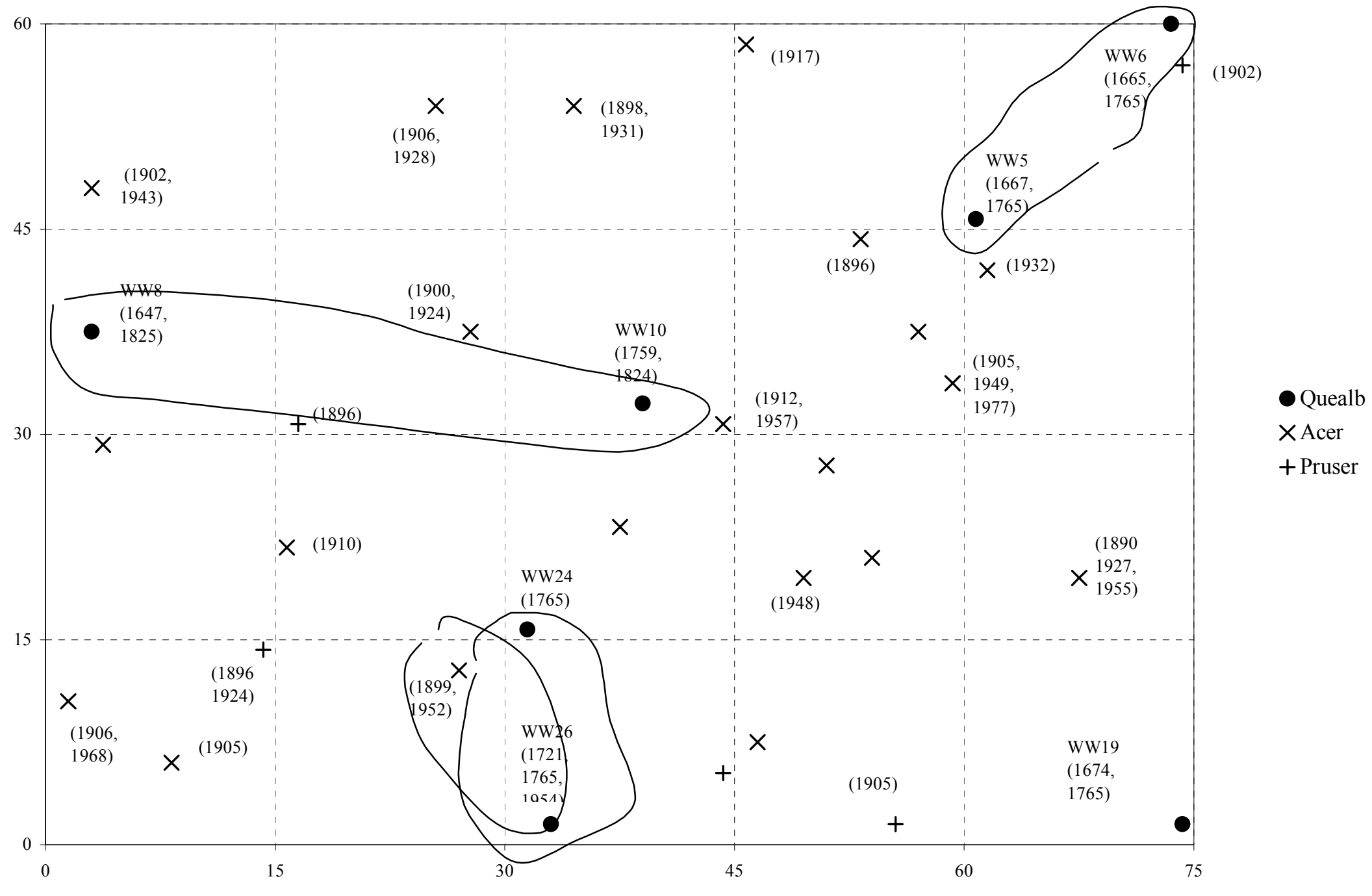


Figure 5.4d. Wrights Woods Plot 2, dbh-age and release-dates, and cohorts of cored canopy trees.

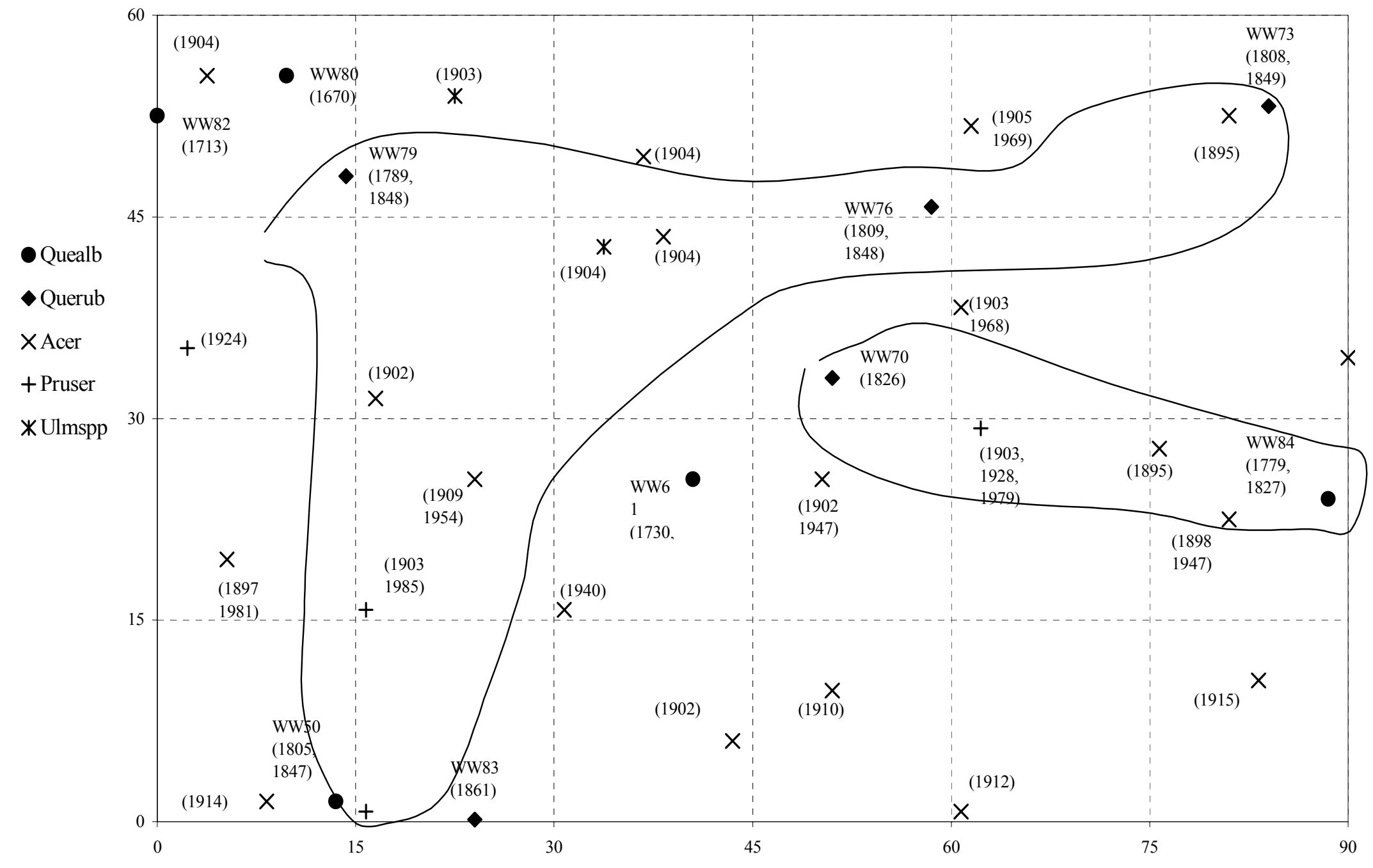


Figure 5.4e. Watter Smith State Park dbh-age and release-dates, and cohorts of cored canopy trees.

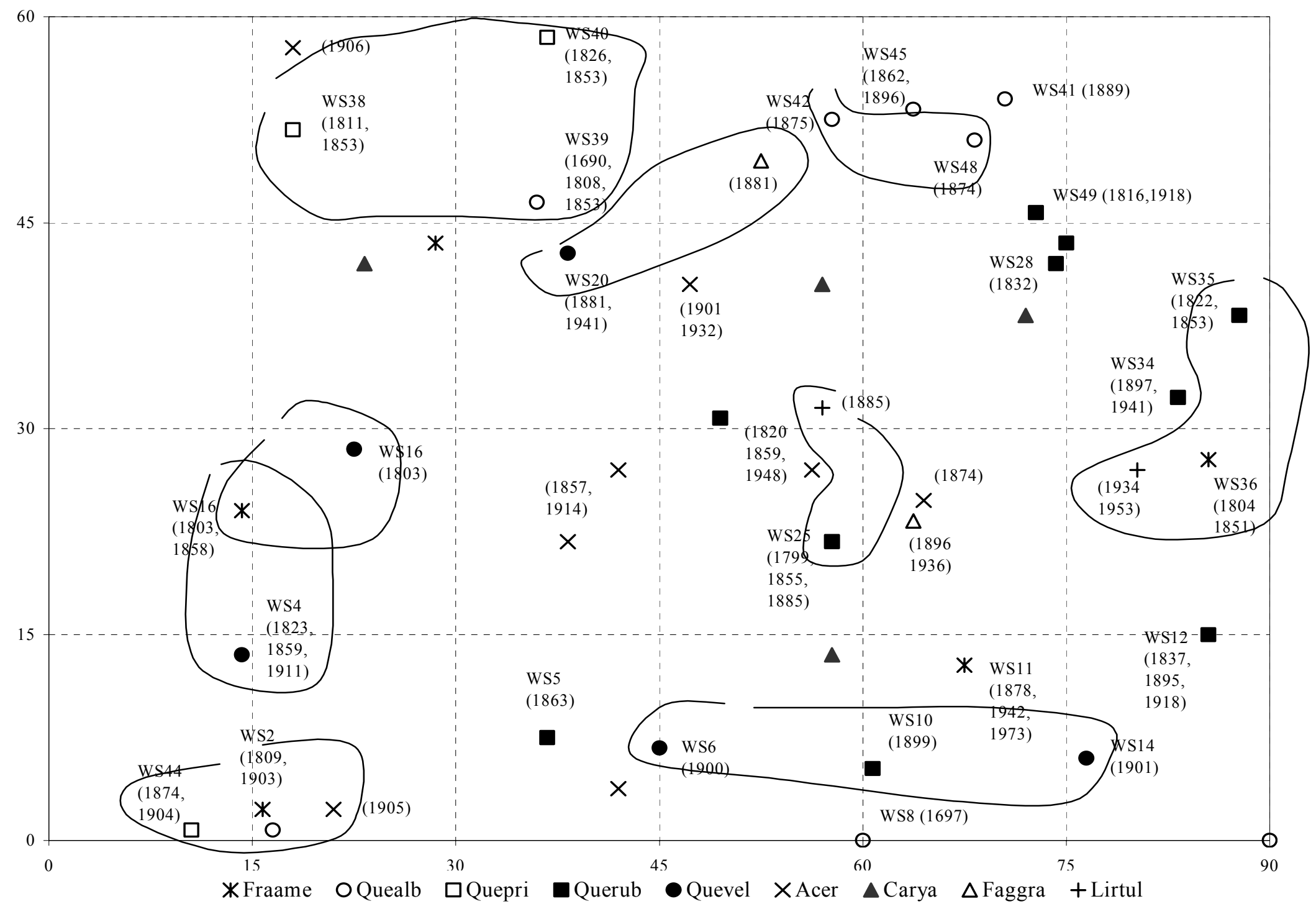


Figure 5.4f. Murphy Tract Plot 1 dbh-age and release-dates, and cohorts of cored canopy trees.

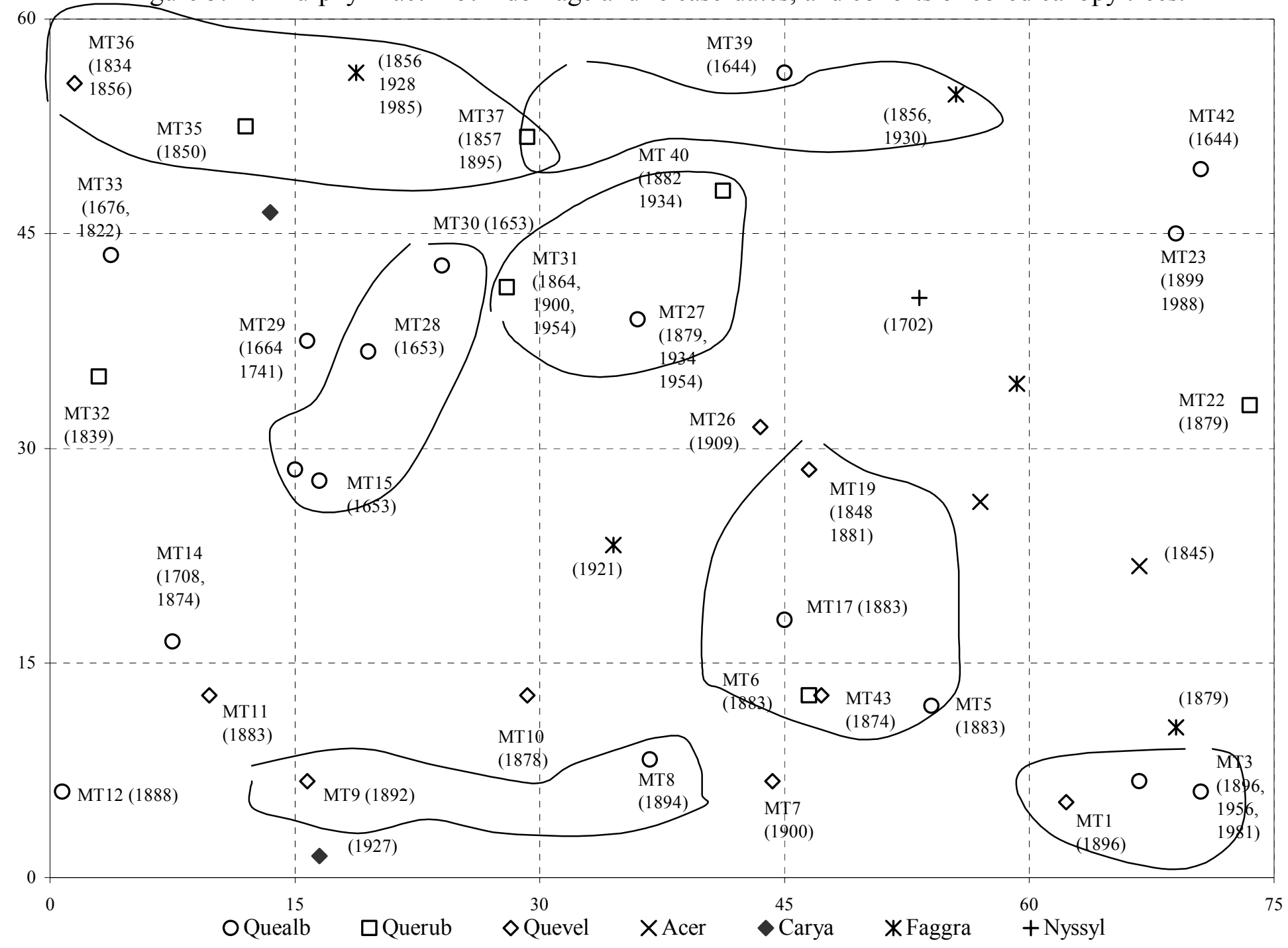


Figure 5.4g. Murphy Tract Plot 2 dbh-age and release-dates, and cohorts of cored canopy trees.

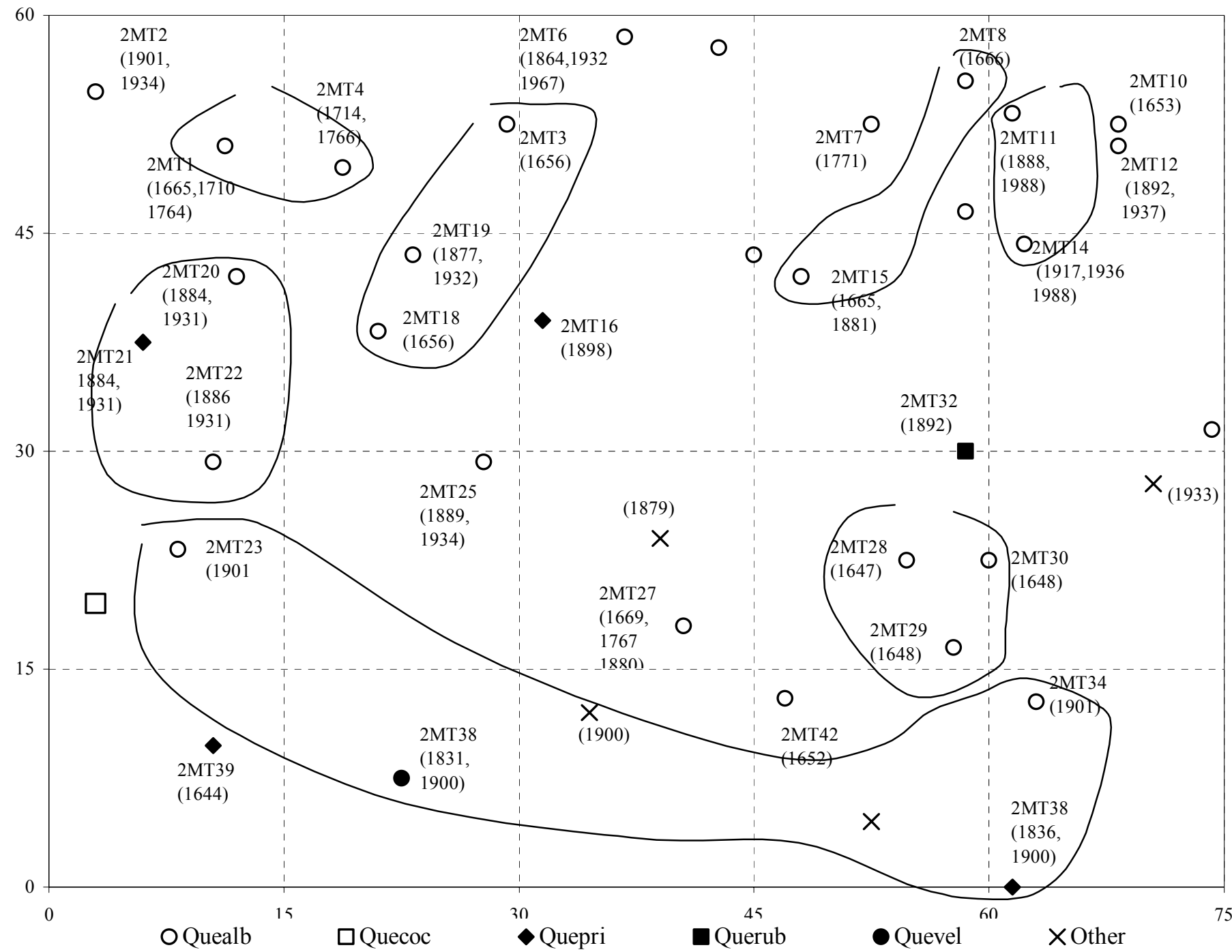


Figure 5.4h. Horners Woods Plot $1 \mathrm{dbh}$-age and release-dates, and cohorts of cored canopy trees.

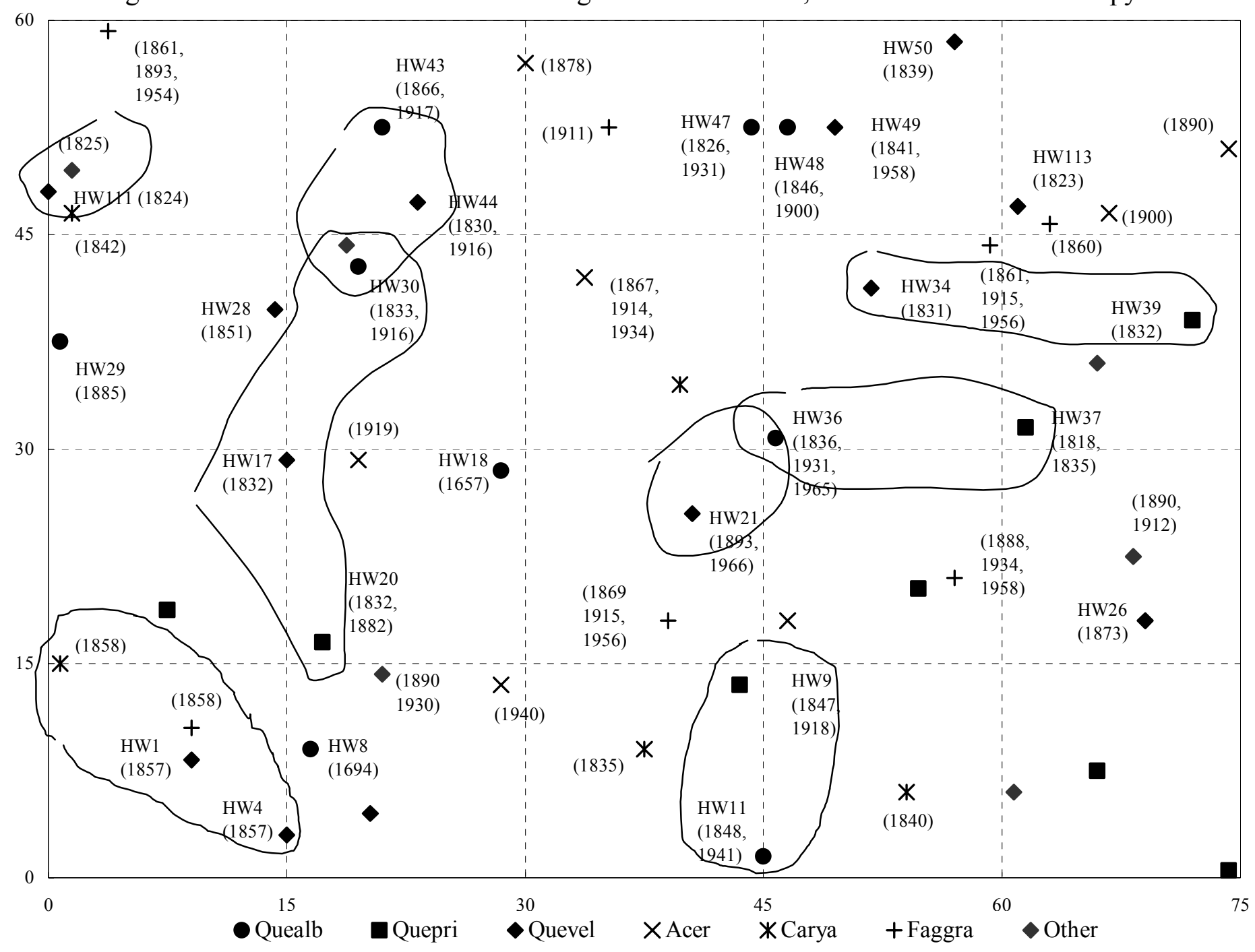


Figure 5.4i. Horne's Woods Plot 2 dbh-age and release-dates, and cohorts of cored canopy trees.

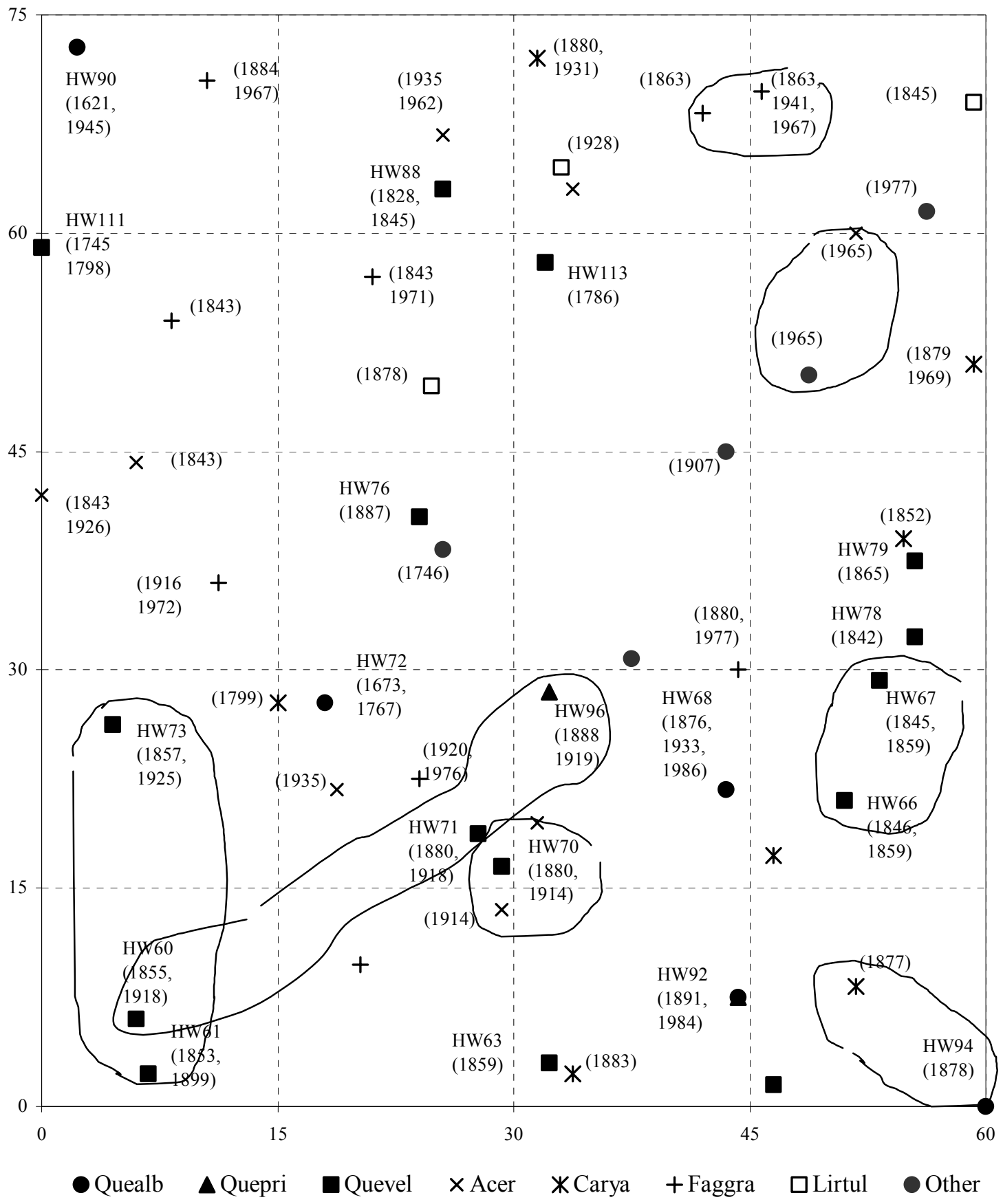


Figure 5.5. Probability of a thunderstorm with winds in excess of $92 \mathrm{~km} \mathrm{hr}^{-1}$ (57 mph) hitting any point in five general areas, based on 1980-1994 data. Adapted from National Severe Storms Laboratory (2001).

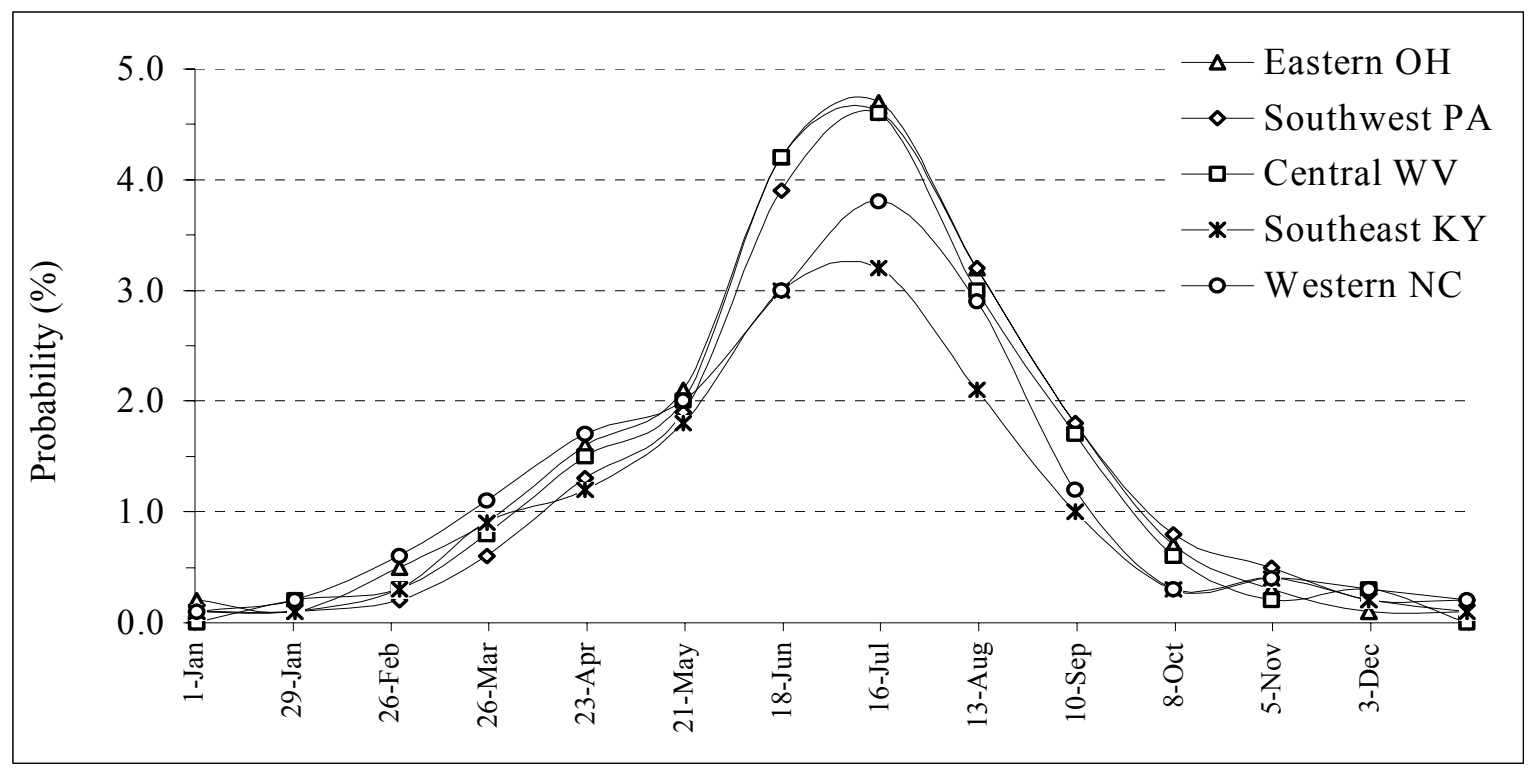

Figure 5.6. Chronology of oak tree-origin and canopy accession dates for five oak-dominated old-growth study sites.

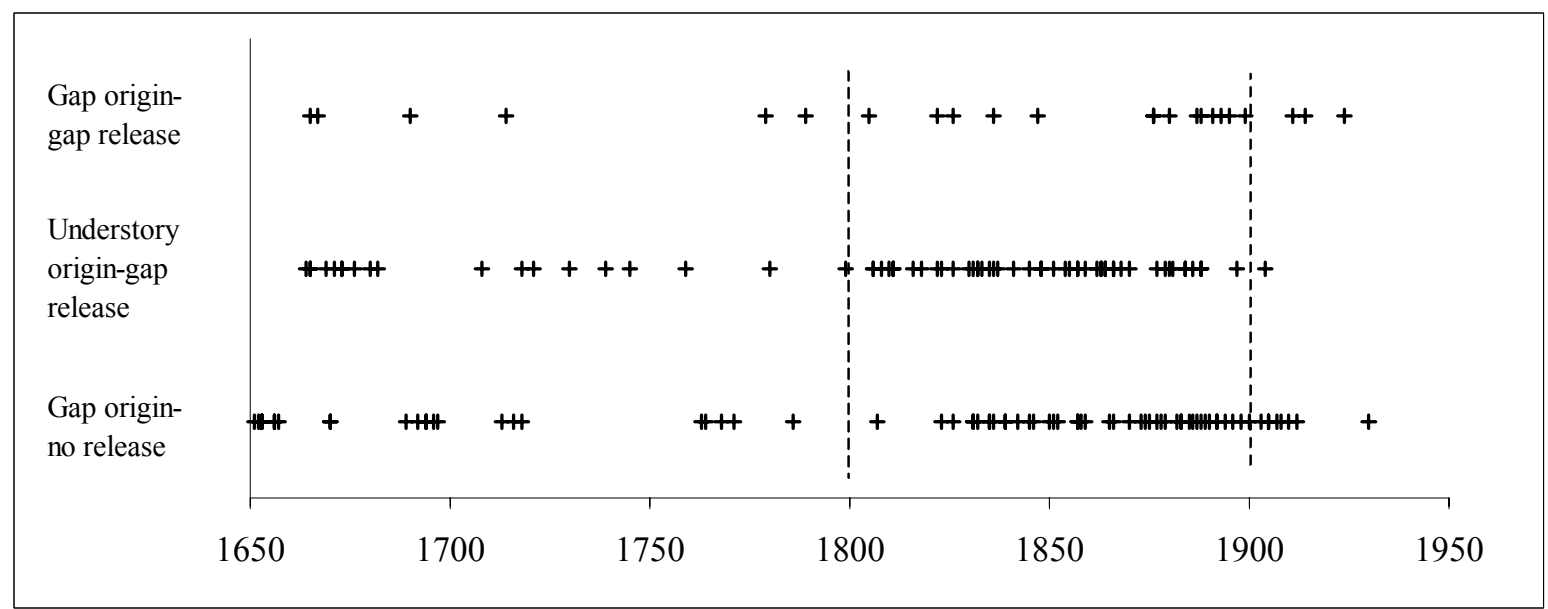

